FERDINAND MIRANDA REIS JUNIOR

\title{
O LINK COMO FATOR DE COERÊNCIA EM HIPERTEXTOS NOTICIOSOS BRASILEIROS E ALEMÃES
}

Dissertação apresentada ao Departamento de Letras Modernas da Faculdade de Filosofia, Letras e Ciências Humanas da Universidade de São Paulo como requisito parcial para a obtenção do título de Mestre em Letras. Área de concentração: Língua e Literatura Alemã Orientadora: Prof. ${ }^{\text {a }}$ Dr. ${ }^{\text {a }}$ Masa Nomura

São Paulo 


\section{Agradecimentos}

A elaboração de um trabalho científico leva em conta longos períodos de pesquisa e dedicação aos estudos, os quais não são feitos sem esforços. Noites em claro, estadias em bibliotecas, dias inteiros em frente a computadores tornam este trabalho aparentemente técnico. No entanto, predecessores às análises de corpora estão pessoas e instituições que se revelam fundamentais neste processo científico, não destoado, porém, de caráter sentimental.

Portanto, esta dissertação é fruto, em primeiro lugar, do afeto das pessoas que estiveram ou estão ao meu lado desde 2001, data de início de minhas pesquisas acadêmicas. Destaco os meus familiares, em especial meus pais, Ferdinand e Ivone, que sempre compreenderam os propósitos da vida acadêmica, e minha irmã, Jacira, pelas primeiras felicitações quando do ingresso na Universidade de São Paulo; minha namorada, Lúcia, pela motivação e pela constante valorização do meu trabalho; meus tios Kleber e Janete, bem como minhas primas Christiane e Cristina, por terem gentilmente cedido um lar quando me transferi para São Paulo, além do afeto e paciência que tiveram durante este período.

Tenho profunda gratidão pela minha orientadora, Prof. ${ }^{\text {a }}$ Dr. ${ }^{a}$ Masa Nomura, que aceitou um orientando despreparado e alheio ao meio acadêmico, em nível de Iniciação Científica em 2001. A sua confiança tácita nas minhas pesquisas fortaleceu-me nos momentos que mais precisava e o reconhecimento de meus esforços faz dela uma diretriz que me dirige cada vez mais aos meandros científicos.

Agradeço cordialmente à Prof. ${ }^{\mathrm{a}}$ Dr. ${ }^{\mathrm{a}}$ Eliana Fischer, pelos primeiros passos na língua alemã e à concessão de uma bolsa, disponibilizada pelo $\mathrm{CNPq}$; às bibliotecárias do Instituto Goethe, que imensamente auxiliaram em pesquisas preliminares com jornais impressos oriundos da Alemanha; à Universidade de São Paulo e a todos os professores da Subárea de Alemão, pela formação humanística e científica; enfim, àqueles que não foram citados. 
Sumário

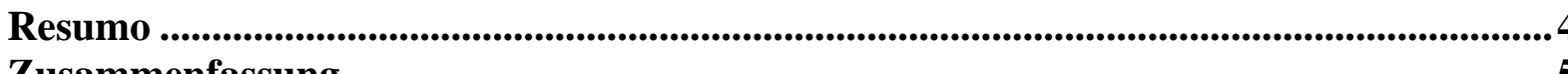

Zusammenfassung ...............................................................................................................................5

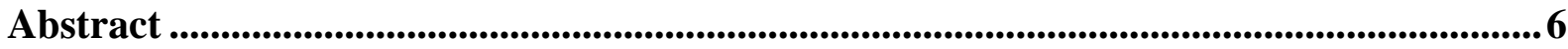

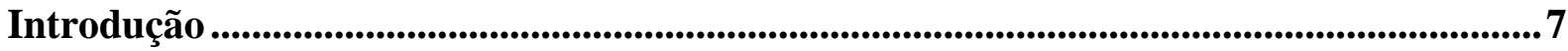

Capítulo 1. Pressupostos Teóricos...................................................................................................14

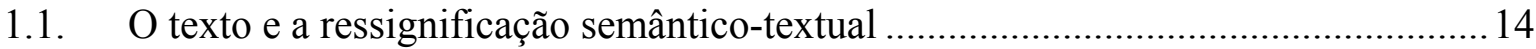

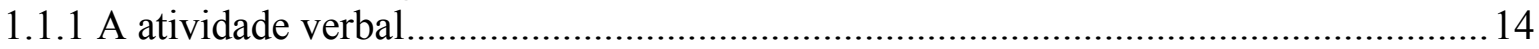

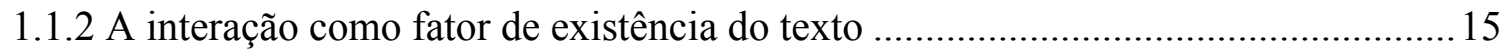

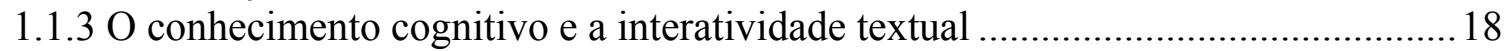

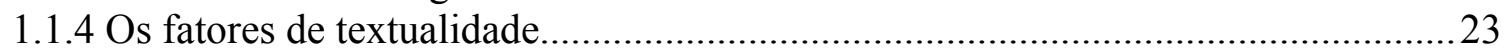

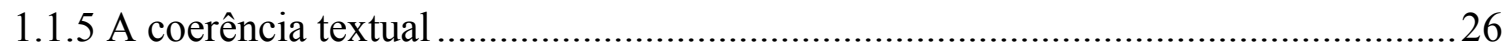

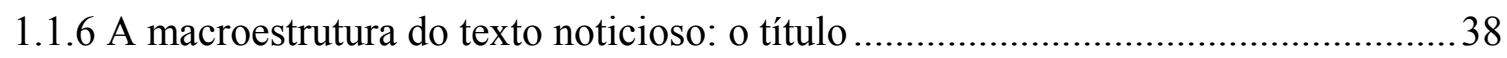

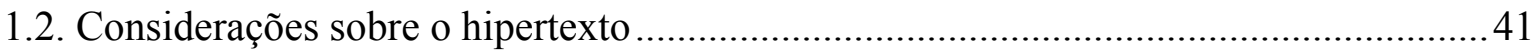

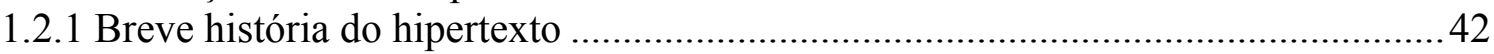

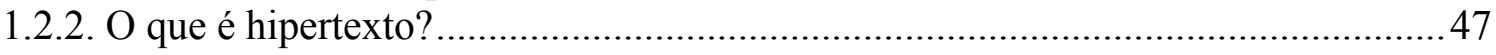

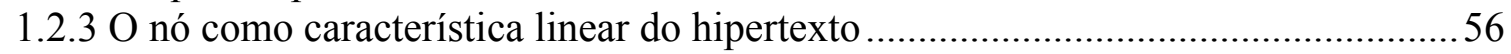

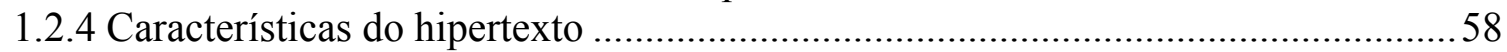

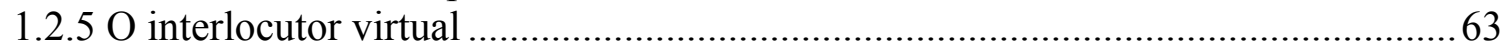

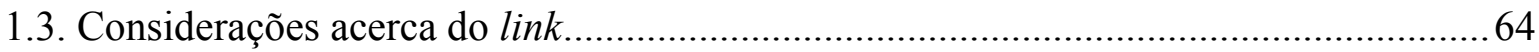

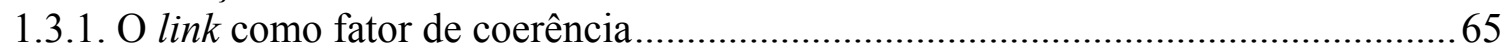

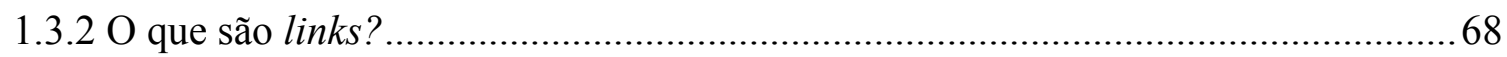

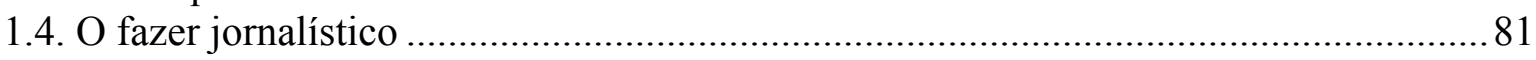

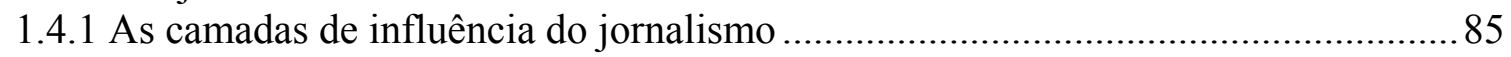

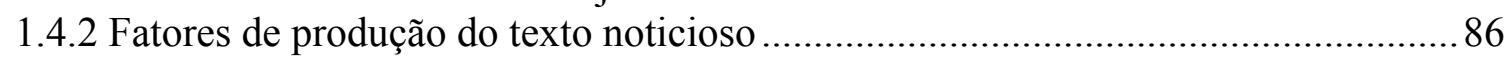

$1.5 \mathrm{O}$ jornalismo impresso e o webjornalismo: semelhanças e diferenças........................... 89

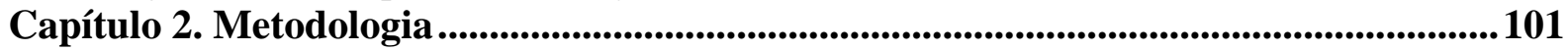

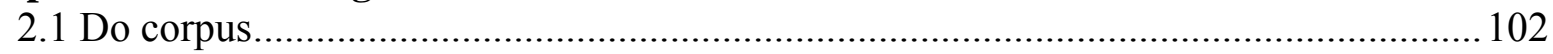

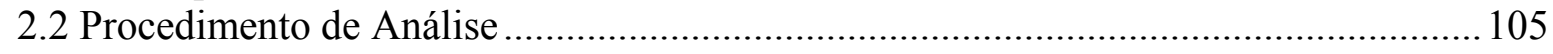

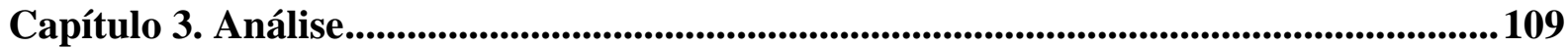

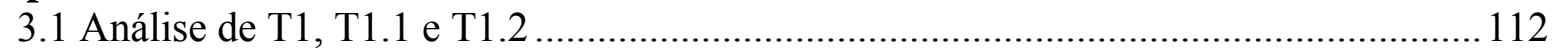

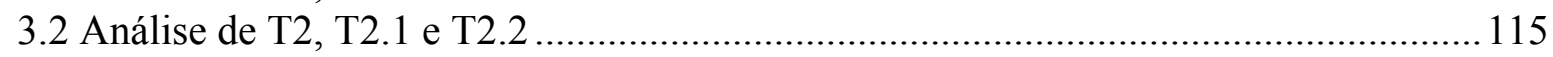

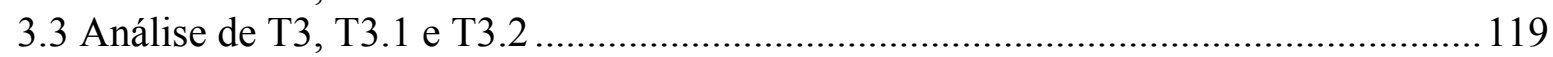

3.4 Análise de T4, T4.1 e T4.2 …................................................................................ 123

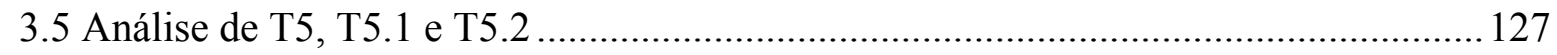

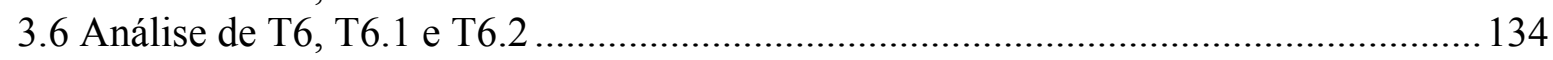

3.7 Análise de T7, T7.1 e T7.2 …................................................................................... 141

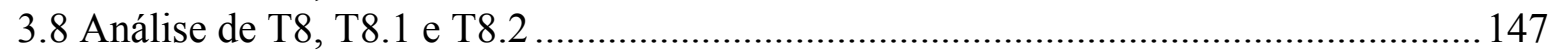

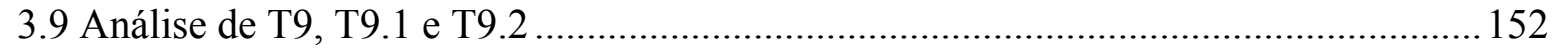

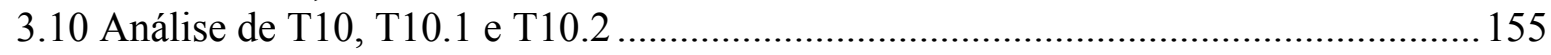

4. Os quadros hierárquicos das respectivas análises .................................................. 160

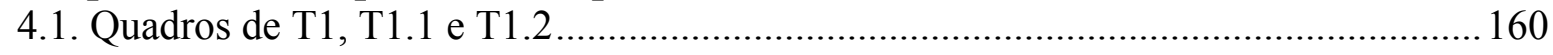

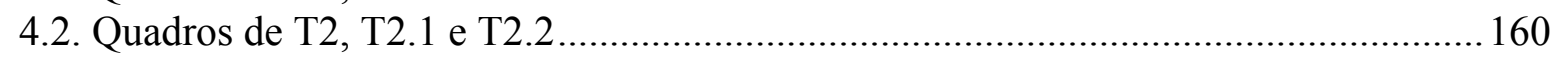

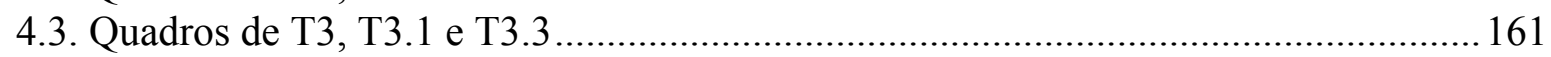

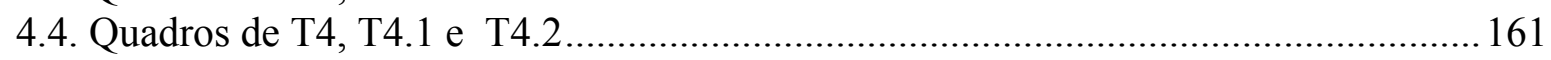

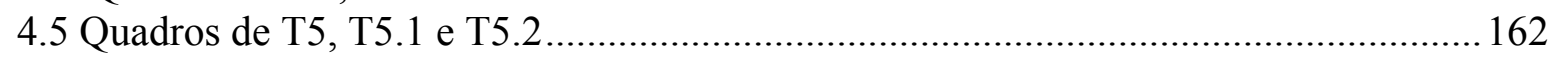

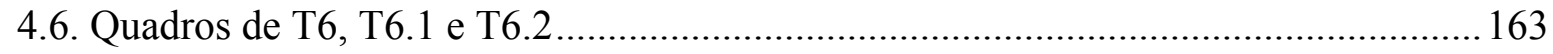

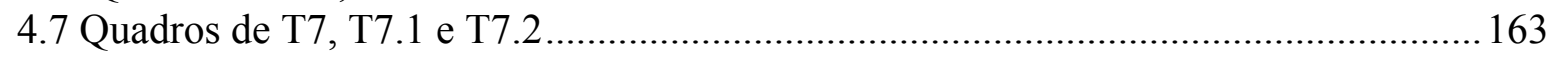




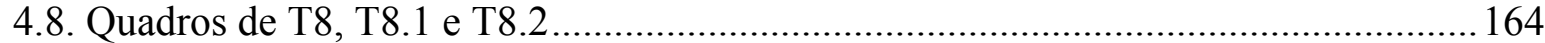

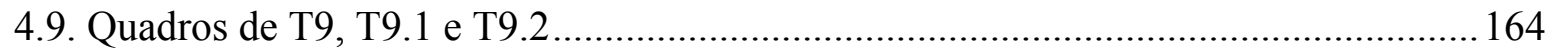

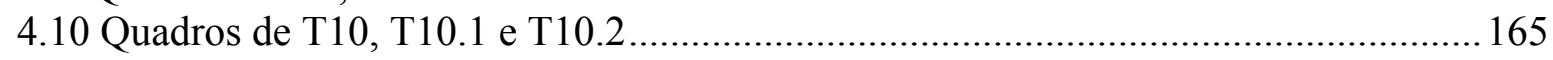

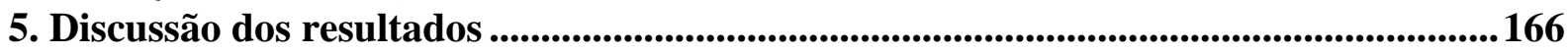

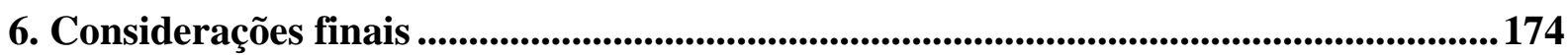

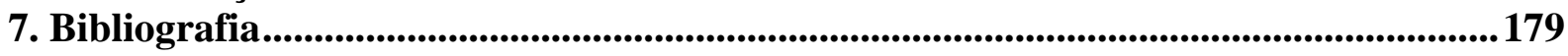

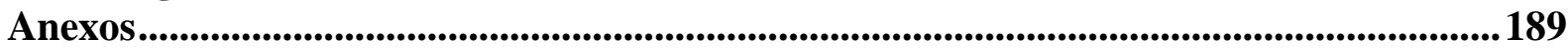




\section{Resumo}

Este trabalho tem por objetivo analisar os links como fatores de coerência em hipertextos jornalísticos brasileiros e alemães com uso de conceitos da lingüística textual, de teorias do hipertexto e do webjornalismo. Intenta demonstrar a continuidade de sentidos entre os hipertextos jornalísticos analisados e seus respectivos links. Observa se esses elos links atuam como operadores estratégicos no discurso jornalístico, isto é, se são elaborados pelo jornal de modo a adquirir funções de não somente interligar dois hipertextos noticiosos, mas também de oferecer ao interlocutor um conteúdo informativo relevante a partir da construção textualdiscursiva do link. Para a pesquisa, foram selecionados dez hipertextos do jornal brasileiro Folha Online (FN) e dez do jornal alemão Frankfurter Allgemeine Zeitung. NET (FN), analisados de modo a formar pares que tratam do mesmo acontecimento. O estudo contrastivo dos links da perspectiva tanto lingüística quanto do webjornalismo leva a questões concernentes não somente às construções textuais-discursivas, mas também aos meandros da prática jornalística residente em culturas distintas, como a brasileira e a alemã, sobre o papel do jornal no domínio do caos informativo que é a Internet. 


\section{Zusammenfassung}

Die vorliegende Arbeit behandelt die Links als Kohärenzinstrumente in brasilianischen und deutschen journalistischen Hypertexten anhand einiger Konzepte der Textlinguistik, der Hypertexttheorien und des Webjournalismus. Das Ziel ist zu beweisen, dass Kohärenzbeziehungen zwischen den analysierten journalistischen Hypertexten und ihren Links hergestellt werden können. Das Ergebnis zeigt, dass einige Hypertextmerkmale dadurch neu geschrieben werden müssen. Es lässt sich auch beobachten, dass diese Links als strategische Werkzeuge in journalistischen Texten verwendet werden, das heißt, dass sie absichtlich von der journalistischen Anstalt aufgebaut werden, um nicht nur Hypertexte miteinander zu verknüpfen, sondern auch um dem Leser weitere relevante Informationen zu geben. Zehn Hypertexte aus der brasilianischen Zeitung Folha Online (FO) und zehn weitere aus der deutschen Frankfurter Allgemeinen Zeitung. NET (FN) wurden ausgewählt und paarweise analysiert, vorausgesetzt, dass sie über das gleiche Ereignis berichten. Die vergleichende Analyse der Links jeweils unter linguistischen und webjournalistischen Gesichtspunkten kann Fragen abrufen, die sich nicht nur auf den Aufbau des Textes beziehen, sondern auch auf die Besonderheiten der journalistischen Praxis. Darauf konzentriert sich die Rolle der Zeitung im Verhältnis zu der zahlreichen Menge von Informationen, die im Internet vorfindbar sind. 


\begin{abstract}
In this work we analyze the role of the links as coherence tools both in Brazilian and German online news by applying conceptual findings from the fields of text linguistics, hypertext theories and online journalism. The purpose is to show that there is a sense continuation between the analyzed hypertexts and their links. We also observe that these links appear as strategic constructions in the news discourse and are intended to serve not only as hypertext connections, but also to provide further relevant information to the reader. Our corpus consists on ten hypertexts from the Brazilian online newspaper Folha Online (FO) and another ten from the German Frankfurter Allgemeine Zeitung Online (FN). They were chosen according to researches that had demonstrated similarities in the editorial performance between the two journalistic enterprises. Each two of these twenty online news are focused on the same events. The contrastive research of the links from linguistic and online journalistic perspectives can reveal issues that concern not only the text/discourse construction, but also the journalistic praxis in two different cultures, the Brazilian and the German. This allows us to analyze the online journalistic role in its relation to the great amount of information in the Internet.
\end{abstract}




\section{Introdução}

Investigar fenômenos concernentes à rede mundial de computadores é uma tarefa multidisciplinar e, ao mesmo tempo, relativamente recente, dado o ineditismo da Internet no Brasil. A utilização comercial da mesma, iniciada na década de 90, tornou a rede gradativamente acessível a um número cada vez mais abrangente de interlocutores pertencentes a diferentes classes socioeconômicas. Em seu início, foi possível observar a disponibilização da informação a partir de instituições e conglomerados empresariais como meras prestações de serviços a cidadãos abastados. Nota-se, nos dias de hoje, diários eletrônicos, denominados weblogs ou blogs, e broadcasts, ainda sem um termo em português, que se caracteriza como uma oferta de vídeos a serem vistos pelos interlocutores da rede. Diversificou-se, portanto, não somente o acesso a este meio de comunicação tecnológico, mas também a interface e a necessidade do mesmo.

Neste período de transição ainda em movimento, nota-se a evolução do caráter informativo da rede e, consequentemente, a maneira de oferecê-la aos seus possíveis interlocutores. A grande quantidade de informação localizada na Internet faz com que novas maneiras de atrair a atenção dos interlocutores sejam desenvolvidas e utilizadas em grande escala. Assim, em primeira instância, viu-se a simples troca da palavra "test" entre dois computadores de instituições americanas interligados por fios. Atualmente, nota-se um mundo paralelo, no qual é possível realizar tarefas nunca pensadas senão no aspecto físico e burocrático, e esse aspecto vem se desenvolvendo de maneira intensamente acelerada, tornando as pesquisas empreendidas no mundo virtual ainda mais importantes.

A rede mundial de computadores já não corresponde a esta denominação, ou seja, a interligação virtual não é somente uma conexão entre máquinas que alcançam qualquer localidade do planeta e, conseqüentemente, seus interlocutores. A Internet preconiza cada vez mais o surgimento de uma pseudo-realidade, na qual existem pessoas, mundos e instituições que se retroalimentam em um existencialismo não-existente. É uma realidade irreal, a qual é fruto de cálculos matemáticos e engenharias computacionais e, por outro lado, ainda operada pelos homens, fazendo com que a interação binária máquina-máquina adquira uma dimensão multifacetada, já que há seres humanos por trás disso. Trata-se de uma disputa entre as potências técnico-eletrônicas e a complexidade dos seres vivos. 
Esse digladiar de forças torna o estudo dos aspectos virtuais ainda mais crucial, já que ao mesmo tempo em que a rede mundial de computadores é somente um aspecto técnico, ela adquire características inéditas quando de sua manipulação pelo homem. O seu desenvolvimento é pautado nessas inserções obtidas pelo trabalho de alguém que procura dominar este universo paralelo e que o utiliza de acordo com seus interesses e, obviamente, com a disponibilização daquilo que o interlocutor deseja. Este processo técnico e manipulador é notado na construção e na plasticidade do hipertexto, pois é produto da linguagem, “[...] uma das faculdades cognitivas mais flexíveis e plásticas adaptáveis às mudanças comportamentais e a responsável pela disseminação das constantes transformações sociais, políticas, culturais geradas pela criatividade do ser humano" (MARCUSCHI \& XAVIER, 2004, p. 7).

Mas como analisar um texto suportado em um caos informativo, se os princípios fundamentais de existência do texto são a organização e a lógica entre suas partes? Inédito em sua forma, descentralizadora e rizomática (MARCUSCHI: 1999), o hipertexto é assim denominado devido à sua capacidade de atualização instantânea e por estar suportado em um contexto prescindível de organização técnica? É possível analisar o hipertexto à luz das contribuições da lingüística textual, principalmente em relação aos aspectos de coerência, que dizem respeito à uniformidade de sentidos estabelecida mutuamente entre os excertos do texto?

Estas indagações instigam uma pesquisa que procura demonstrar que o advento do hipertexto em meio eletrônico sugere duas prováveis problemáticas, que não se mostram antagônicas, mas paralelas:

1) A investigação sobre o hipertexto noticioso parte dos pressupostos teóricos acerca do hipertexto, mas levam em conta conceitos tratados na Lingüística Textual, já que um hipertexto noticioso é hiper, ou seja, está baseado em um suporte que maximiza as possibilidades interativas entre as instâncias textuais e a máquina. Assim, nota-se que apesar de ser um tipo de texto com diferentes características daqueles produtos oriundos do papel ou da atividade oral, o estudo do texto suportado pela rede mundial de computadores conserva características tradicionais, já observadas em outras pesquisas; 
2) Os estudos acerca do hipertexto noticioso demonstram que alguns conceitos relativos às pesquisas que tomam como base o texto tradicional e linear são passíveis de alteração. Desta maneira, estes resultados podem ser aplicados a textos impressos, da mesma maneira que a Análise da Conversação contribuiu para o âmbito da Lingüística Textual. Algumas indicações advindas do estudo do hipertexto podem somar características ainda não notadas quando das análises de textos escritos ou orais.

O texto é um dos produtos da linguagem, caracterizado a partir de aspectos estruturais e semânticos, por um lado, e por meio de diretrizes pragmáticas, quando se aporta nos quesitos contexto e conhecimento. Logo, nota-se que o texto não é um meio de transmissão de conhecimentos auto-suficiente, ou seja, que tem sua existência calcada somente em aspectos internos a ele, mas adquire status de esclarecedor de mundos a partir de sua ressignificação operada de acordo com a competência de interlocutores de compreendê-lo como tal (KOCH: 2004). Em outras palavras, um texto é um produto binário desenvolvido a partir de processos interativos entre dois ou mais interlocutores e que o constróem de maneira conjunta atendendo a fatores de natureza social. Isso não remete à idéia de que um texto não seja passível de estudos e análises a partir de seu estado inerte, o que leva em conta os possíveis efeitos de sentido que podem ser gerados quando de sua exploração pelos interlocutores. Admite-se, portanto, que uma análise é uma leitura e, conseqüentemente, outras são plenamente plausíveis e possíveis.

A coerência desponta como um fator preponderante para a existência e compreensão dos textos, pois se refere diretamente à questão da organização e dos sentidos. Assim, é possível falar, de acordo com van Dijk (2002), em uma coerência local e uma coerência global. A primeira diz respeito aos aspectos de coesão, ou seja, à superfície do texto e a sua concatenação lógica. Já o segundo conceito refere-se aos sentidos subjacentes à estrutura superficial do texto, desencadeados a partir da atualização do texto em relação aos conhecimentos do interlocutor adquiridos a partir de suas experiências diretas e indiretas com o mundo. Assim, é possível afirmar que a coerência não está no texto, mas é desencadeada a partir dele. O estudo da continuidade de sentidos em hipertextos, os quais se caracterizam como descentralizados e mutáveis com relação aos seus elementos textuais, é crucial para avaliar se estes aspectos aplicam-se a todos os tipos de texto. 
O hipertexto é um gênero discursivo ambientado em um suporte ainda recente e em constante mutação e que, dada a importância do contexto nos aspectos lingüistico-textuais, altera essencialmente esta produção textual em ambiente eletrônico. Primeiramente, devido à arquitetura hipertextual, caracterizada pela existência de nós ou blocos informativos, que ocorrem na forma de textos, imagens, sons e vídeos. Em segunda instância, pelo processo de atualização instantânea destes dados promovida pela interligação entre dois ou mais hipertextos através de links. Assim, nota-se a existência de um hipertexto permeado por links elaborados a partir deste texto de origem e que as suas estruturas e conteúdos, tornando este texto um objeto delimitado e circunscrito por indicações de relevância em um contexto fundamentalmente caracterizado por um sem-número de informações e, conseqüentemente, por ausências de centralizações temáticas. São estes os dois fatores de existência de textos nós e links, que, a partir de seu suporte, adquirem características inovadoras com relação ao texto tradicional. Desta feita, a necessidade de se estudar o hipertexto ambientado na rede mundial de computadores origina-se do processo de elaboração em ambiente virtual, o que implica transformações substanciais em seus aspectos textuais e, principalmente, as diferenciações que podem ser observadas se comparadas com as características do texto tradicional.

Os links, conforme acima apresentados, adquirem importância quando estudados em conformidade com determinados tipos de texto. É possível, portanto, observar estes links a partir do ponto de vista da lingüístico, recortado por meio do estudo textual e pela formulação destes elos acessíveis; através da visão da arquitetura do hipertexto e de sua formulação e, de acordo com a natureza do texto utilizado para análise, no caso, a partir das investigações desencadeadas no âmbito do jornalismo online. Conseqüentemente, os links apresentam-se como ferramentas multifacetadas e que devem ser analisadas em consideração à sua localização e em quais tipos de texto são empregadas. Desta maneira, em primeira instância são observados como meros dispositivos técnicos que possibilitam a interligação entre textos suportados em ambiente eletrônico. Entretanto, considerados em um sítio jornalístico, estes links adquirem importância concernente não somente ao fato de atuarem como conectores, mas também pela sua construção estratégica que visa indicar ao interlocutor aquilo que é relevante por meio de táticas de construção textual.

As empreitadas relacionadas às pesquisas do texto jornalístico adquirem importância em conjunto com o papel da mídia representado em determinadas sociedades. A evolução 
histórica dos veículos de comunicação e a aglomeração dos mesmos em setores empresariais faz da informação um relato e do relato uma notícia. Daí a idéia de que não são representados fatos e acontecimentos em um jornal, mas a observação dos mesmos a partir de um determinado ponto de vista. Esta observação é fruto de um processo de edição, que compreende desde a busca pela matéria prima, aos processos de seleção de notícias e, por fim, à edição final de um veículo comunicativo. Isso remete à idéia de que há uma construção estratégica de um mundo verossímil, mas que sustenta os pontos de vista de um determinado jornal.

Estes empreendimentos científicos podem sugerir resultados ainda mais concretos quando de um estudo contrastivo. Para isso, amplia-se não somente o tamanho do corpus, mas também se diversificam os seus integrantes, de modo que as considerações finais não digam respeito somente a uma cultura. A interculturalidade também tem sido alvo de constantes indagações, já que a sociedade da informação permite o conhecimento de um mundo até então residente nos papéis e na acessibilidade que estes materiais disponibilizam.

As problemáticas acima delineadas pautarão as discussões neste trabalho. Conforme colocado, o estudo dos links como fatores de coerência em hipertextos não sugerem um paradoxo a ser desvendado, mas uma característica observada em análises dirigidas aos hipertextos noticiosos no jornal Folha Online (FO) e Frankfurter Allgemeine Zeitung.NET (FN). A partir de tais premissas, os objetivos desta pesquisa a partir da perspectiva da lingüística textual são:

1) Observar se os links de hipertextos noticiosos do jornal brasileiro contribuem para uma continuidade de sentidos e, conseqüentemente, debater o conceito de não-linearidade do hipertexto noticioso;

2) Analisar o mesmo aspecto nos links relacionados nos hipertextos noticiosos oriundos do jornal alemão;

Já a partir da ótica do jornalismo online, o objetivo desta pesquisa é

3) Esmiuçar o papel do jornal no que diz respeito à formulação estratégica dos links veiculados em hipertextos por dois jornais de culturas divergentes. Além 
disso, atentar para a perspectiva intercultural com o objetivo de encontrar semelhanças e diferenças no tratamento do link.

Após a análise de cada texto noticioso, realizada em pares, é montado um quadro hierárquico que contém o título da notícia, considerada aqui a estrutura agregadora das relações a serem desdobradas no decorrer do hipertexto, e os respectivos links referentes às hipernotícias analisadas. Desta maneira, procura-se considerar as implicações semânticotextuais entre a proposta de leitura sugerida pelo jornal, caracterizada na manchete, e a elaboração textual dos links. Caso estas hipóteses confirmem-se, referências acerca das estratégias do jornal serão delineadas.

Pelos objetivos acima delineados, este trabalho adquire um caráter eminentemente transdisciplinar, concentrado em duas áreas científicas específicas: a lingüística textual e o jornalismo online. No entanto, a primeira terá, nesta pesquisa, mais relevância, pois as contribuições jornalísticas estão restritas ao estudo da natureza do texto jornalístico e servirão como base para sustentar os argumentos sobre o papel do jornal e as estratégias utilizadas pelos jornais a fim de reconstruir um mundo verossímil e relevante para um determinado público-leitor.

A seguir, são listados os capítulos que compõem esta pesquisa:

O Capítulo 1 diz respeito à fundamentação teórica da pesquisa e está dividido em três partes:

I. O excerto que trata da coerência textual, com base em estudos advindos/ lingüística textual, que almeja os construtos teóricos relacionados às análises textuais e, conseqüentemente, aos efeitos de sentido elaborados em um texto;

II. Conceitos acerca do hipertexto por diversos autores. Neste excerto da pesquisa, contribuições de teóricos tanto dos estudos computacionais como da lingüística, são intercaladas de modo a sustentar os apontamentos que fecharão o aparato teórico relacionado ao hipertexto; 
III. As diferentes definições sobre o conceito de link e, adiante, as considerações acerca da função destes links no hipertexto noticioso;

IV. Discussão acerca do conceito de notícia, implicações do jornalismo online em relação ao uso e elaboração dos links, a fim de sustentar opiniões e persuadir o interlocutor acerca da necessidade da informação e da relevância dos hipertextos noticiosos veiculados pelos jornais.

O Capítulo 2 dá início à parte analítica do trabalho. Sendo assim, serão descritos os métodos de seleção dos jornais que atuaram como fonte para extração do corpus. Os critérios para essa escolha basearam-se em pesquisas anteriores do mesmo autor desta pesquisa que elencaram quatro jornais. Os hipertextos noticiosos recolhidos terão sua justificativa delineada, ou seja, será discutida a razão de se escolher os hipertextos que formam a parte analítica desta pesquisa. Por fim, todas elas serão descritas, de modo a esclarecer seus conteúdos.

O conteúdo analítico é o embasamento para a elaboração do capítulo 3. Assim, os estudos acerca dos hipertextos selecionados foram alvo de discussão, nos quais o estabelecimento da coerência em conjunto com a elaboração estratégica do texto noticioso foram vistos como fenômenos de construção por parte do jornal que, além de comunicar um texto compreensível, nutre o público-leitor com informações relevantes e observadas a partir de um determinado ponto de vista. A partir dessas afirmações, efetuou-se um estudo contrastivo entre os hipertextos noticiosos analisados em conjunto com a elaboração de um quadro hierárquico formado pelo título e pelos links de cada hipertexto noticioso. Neste mesmo capítulo, conclusões parciais foram esmiuçadas com o objetivo de dar início às conclusões finais do estudo.

O capítulo 4 está reservado para a revisão das conclusões parciais e para as considerações finais do estudo. Elas serão direcionadas para a hipótese levantada na introdução deste estudo. Adiante, investigações futuras e necessárias acerca do mesmo tema serão sugeridas sempre no âmbito da lingüística e do jornalismo online.

Por fim, as referências bibliográficas serão listadas, bem como todos os anexos, tanto os textos em português e em alemão. 


\section{Capítulo 1. Pressupostos Teóricos}

\subsection{O texto e a ressignificação semântico-textual}

\subsubsection{A atividade verbal}

A realização verbal engloba, em referência às pesquisas empreendidas por Koch (2003), a língua ou sistema lingüístico; o grau de domínio da língua por parte do sujeito; a escolha dos mais adequados dos caminhos, ou seja, da forma textual mais indicada para determinada situação; o fator afetivo, isto é, a maneira pela qual o texto é expresso; a seleção das formas lingüísticas, obtidas a partir de imagens mentais do sujeito com relação ao seu interlocutor; o contexto lingüístico e a situação comunicativa.

Oriunda da intenção verbal de um sujeito, a ação ou intenção é matéria prima da linguagem. Assim, é uma das manifestações do ser humano e, quando materializada, torna-se uma atividade humana. Nesta condição, a atividade verbal é analisada de acordo com operações e mecanismos que estruturam as marcas sóciocognitivas em um corpus provindo da atividade verbal. O signo lingüístico, quando operacionalizado, atua como estímulo não somente no que diz respeito a uma existência de uma necessidade ou interesse. O interlocutor, para que recepcione adequadamente este signo, deve estar apto a compreendê-lo, ou seja, deve entender todas as relações subjacentes ao texto que atuarão no momento da situação sóciocomunicativa. Daí “[...] a dependência constante da situação em se leva a cabo a atividade, tanto para a planificação geral como para a realização das ações e a possível modificação do processo no decurso da atividade (troca das ações previstas por outras, de acordo com mudanças produzidas na situação)" (KOCH, 2003, p. 13).

A teoria da atividade verbal centra suas preocupações, portanto, na linguagem como ferramenta para o relacionamento entre humanos socialmente ambientados. Vale a pena ressaltar que, em termos lingüísticos, esta teoria remete às operações cognitivas que gerarão mecanismos textuais com o intuito de se levar ao interlocutor uma finalidade dada após uma realização. Daí a tarefa dos estudos dos sentidos no texto: analisar minuciosamente todas as formas de organização que, aparentemente estruturais, já foram adequadas às intencionalidades (atos de fala). Mesclam-se, portanto, os âmbitos lingüísticos e cognitivos, já que um pressupõe a existência do outro. 
A atividade verbal pode ser considerada, portanto, a partir do âmbito sócio-interativo. $\mathrm{O}$ primeiro diz respeito aos dispositivos cognitivos que, quando atuam, entram em contato com a realidade psicossocial do falante, o qual age diretamente naquele espaço que o cerca. Assim, um conjunto de aspectos cognitivos, como motivação, e outros sociais, como situação e prova de possibilidades, interagem e formam e esquematizam a atividade verbal do sujeito.

\subsubsection{A interação como fator de existência do texto}

De acordo com Koch $(2003,2004)$, o conceito de sócio-interacionismo toma o texto como um meio no qual ações são desencadeadas a partir de atividades lingüísticas ocorridas em ambientes sociais, produzidas por sujeitos que têm por finalidade elaborar processos comunicativos. A palavra interatividade refere-se ao contato social entre dois interlocutores, já que vulneráveis a influências sociais, que iniciam intencionalmente uma atividade verbal. Portanto, considera como aspecto motivador da atividade verbal a existência de um sujeito que planeja, organiza e intenta se relacionar com um outro sujeito.

Aspectos como a situação comunicativa, as imagens mentais, interferências institucionais, políticas, sociais e subjetivas refletem-se na atividade verbal e, conseqüentemente, no produto texto. Portanto, ele pode ser considerado como um resultado da atividade cognitivo-discursiva, no qual imprimem-se determinadas características que atuarão na produção e tentativa de reconstrução (por parte do receptor) dos sentidos ali circulantes. A análise das atividades discursivas e suas respectivas marcas provindas da materialidade lingüística norteiam os estudos da construção dos sentidos e, em grande parte, da Lingüística Textual.

As ciências da cognição ponderam os fenômenos desencadeados a partir de sistemas de conhecimento localizados na mente do interlocutor. Os aspectos interiores, deste ponto de vista, são uma fonte de formação da mente humana. Assim, a relação entre cognição e cultura dar-se-ia a partir do momento em que a experiência vivida, ou seja, a vida social do sujeito fosse transmitida aos seus sistemas de conhecimento. 
Segundo essa visão, a cultura é um conjunto de dados a serem apreendidos, um conjunto de noções e procedimentos a serem armazenados individualmente. É fácil ver que, partindo desse ponto de vista, a cultura é subsidiária e dependente do conjunto de mentes que a compõem, ou seja, um fenômeno em geral passivo, sobre o qual as mentes atuam (KOCH, 2004, p. 29-30).

A atividade de interação com o mundo possibilita a interação com um outro sujeito. Daí a necessidade de se qualificar o físico, o existencial, o social, o cultural aliado às concepções cognitivas. A cognição é, portanto, fruto do agir sobre o conhecimento, dos processos que desencadeiam as elaborações conceituais. É a prática sobre a realidade que construirá o sistema cognitivo do indivíduo. De acordo com Koch (2004), a cognição está diretamente ligada às características contextuais eminentes de um gênero discursivo, as quais são socialmente modeladas. Assim, ações verbais não são individuais, mas sim, conjuntas, e devem ser observadas de modo momentâneo (não descartando, obviamente, o processo histórico no qual se encontram). Julga-se a linguagem com movimento duplo: sujeito/ mundo (intercognitivo) e linguagem/ outras formas de cognição (intracognitivo):

Cognição aqui se define como um conjunto de várias formas de conhecimento, não totalizado por linguagem, mas de sua responsabilidade: os processos cognitivos, dependentes, como linguagem, da significação, não são tomados como comportamentos previsíveis ou aprioristicamente concebidos, à margem das rotinas significativas da vida em sociedade. O tipo de relação que se estabelece entre linguagem e cognição é estreito, interno, de mútua constitutividade, na medida em que supõe que não há possibilidades integrais de pensamento ou domínios cognitivos fora da linguagem, nem possibilidades de linguagem fora de processos interativos humanos. A linguagem é tida como o principal mediador da interação entre as referências do mundo biológico e as referências do mundo sociocultural (MORATO, cit. por $\mathrm{KOCH}, 2004$, p. 32).

De acordo com van Dijk (2002), um exemplo concreto referente à produção lingüística, na qual se observam diferentes fatores em simultaneidade, é o fato de que um mesmo acontecimento pode ser recontado de diversas maneiras. No entanto, trata-se de um processo de reatualização de sentidos em conjunto com aspectos referentes à produção textual. Desta forma, faz-se necessário descrever as etapas didaticamente para que o fenômeno de incorporação de proposições a um texto-base seja mais bem observado. Assim:

- A observação do mesmo fato envolve diferentes perspectivas de olhares e lingüísticas e, portanto, constrói-se na mente dos falantes um esquema 
informativo que remontará textualmente àquele ocorrido. Trata-se do pressuposto informativo;

- Em segunda instância, quando um destes interlocutores desejar recontar este fato, há uma reconstrução textual de um estado de coisas mediada e dotada de determinadas propriedades, além de baseada em esquemas culturalmente partilhados. Nota-se, portanto, um pressuposto construtivista ou reconstrutivista;

- Este processo narrativo virá acompanhado de um panorama avaliativo. Como já referido, o papel do conhecimento idiossincrático concerne às experiências individuais ambientadas em uma sociedade. Desta forma, apesar de haver um compartilhamento intercultural entre as formas de conhecimento, há aspectos subjetivos na produção e recepção de textos. Tem-se, então, o pressuposto interpretativo e

- Por fim, nota-se que a questão da interatividade diz respeito às trocas lingüísticas efetuadas entre dois ou mais interlocutores e, desta maneira, às problemáticas concernentes ao planejamento textual. Assim, a pressuposição online diz respeito à simultaneidade entre os processos de construção textual de um acontecimento e processamento da informação, o que significa que a memória episódica e as informações deste fato são trabalhadas ao mesmo tempo. A pressuposição online é mais facilmente notada em textos relativamente não-planejados (URBANO: 1997).

Assim considerados os estágios de produção lingüística advinda da atividade verbal, nota-se que este processo está relacionado tanto com componentes sociais e psicológicos, como com aspectos individuais, em sintonia, portanto, com os pressupostos sócio-interativos. Pode-se afirmar, portanto, que o trabalho lingüístico é concernente também à intenção do interlocutor, aspecto subjetivo que motiva a atividade. Assim, este fator pessoal não é único em um produto lingüístico, mas se consideram também os fatores situacionais que interferem no produto oriundo da construção lingüística. O conceito de contexto refere-se ao lugar da interação, na qual atores sujeitos são construídos. Assim, a atividade verbal é interativa, na 
qual conhecimentos não são somente empregados, mas negociados e atualizados constantemente.

O componente situacional afeta o interlocutor e altera o modo de formalizar sua atividade verbal. É dependente dos conhecimentos anteriores que o interlocutor possui acerca da situação comunicativa na qual se encontra. Testando-se diferentes possibilidades, o sujeito procura determinar, direta ou indiretamente, qual ação rende os melhores resultados (van DIJK: 2002). Por fim, escolhe-se aquela na qual se obtém êxito, advinda das expectativas do sujeito com relação ao interlocutor e à situação comunicativa. São fatores que interferem no produto lingüístico a partir de elementos da atividade verbal e do contexto sóciopsicológico: motivação, situação, prova de probabilidades e tarefa-ação. Passa-se à elaboração da organização interna do texto e concretiza-se, verbalmente, a intenção verbal.

Os pressupostos cognitivos contemplados nos estudos do texto trouxeram à tona problemáticas oriundas da relação da linguagem com:

1) A experiência do indivíduo com a realidade;

2) Com o processo de interiorização do mundo e

3) Com a construção de discursos e textos baseados no conhecimento de mundo dos interlocutores.

\subsubsection{O conhecimento cognitivo e a interatividade textual}

A tríade entre linguagem, pensamento e realidade sugere que o texto não é somente semântico-estrutural, mas também cognitivo, pois está diretamente relacionado à memória discursiva dos interlocutores e ao respectivo conhecimento de mundo de cada um.

Os recipientes textuais pensam em conjunto com o texto. Eles organizam estruturas textuais e, onde elas não existem, constróem relações entre os elementos do texto. Caso estas não sejam dedutíveis, eles ordenam e interligam o texto de acordo com unidades de informação seguindo modos significativos, mesmo quando uma outra ordem é observada na 
superfície textual. Advém daí o conceito de trabalho textual ${ }^{1}$. A fim de ativar meios para a elaboração da coerência textual, é importante discorrer acerca do conhecimento, peça-chave na construção da coerência em textos.

A existência do conhecimento extralingüístico e a compreensão textual. A existência do conhecimento é de natureza peculiar e as maneiras que ele ocorre são, apesar de divergentes, complementares. Não é possível aqui uma explanação mais específica sobre este tema, mas se tentarão algumas considerações a respeito do processo de elaboração da coerência ${ }^{2}$, relevantes para este campo de estudo.

Os sistemas de conhecimento, de acordo com Koch (1988, 2003, 2004), podem ser divididos em:

1) Lingüístico: refere-se aos conhecimentos das estruturas lingüísticas e dos traços semânticos das palavras;

2) Conhecimento de mundo ou enciclopédico, independente de fatores locais ou culturais. Segundo Linke, Nussbaumer \& Portmann (1994), é circunscrito por diferentes conteúdos de conhecimento ${ }^{3}$, considerados de conhecimento cotidiano ${ }^{4}$ que age no conhecimento de experiência individual até conhecimentos específicos e científicos. As características em comum desta classificação residem no fato de que estes conhecimentos são inventários e remetem a objetos. De acordo com Heinemann \& Viehweger (1991), é divido em: a) Declarativo: refere-se a estados de coisas. A frase "o mar é azul" é um exemplo deste tipo de conhecimento, pois reporta uma proposição lógica (KOCH: 1988); b) Episódico: apreendido através de experiências socioculturais e diz respeito a frames, scripts, planos, cenários, esquemas e superestruturas ${ }^{5}$, que

\footnotetext{
${ }^{1}$ Textarbeit.

${ }^{2}$ Kohärenzherstellung.

${ }^{3}$ Wissensinhalte.

${ }^{4}$ Alltagswissen.

${ }^{5}$ De acordo com Koch (1988, p. 158-159), “[...] Frames são representações fixas de conhecimentos sobre o mundo armazenados sob certo rótulo, isto é, em torno de um conceito central. Esquemas são frames cujos elementos se apresentam ordenados numa progressão, por contigüidade temporal ou causal, sendo, pois, fixos e previsíveis. Planos são esquemas organizadores de acontecimentos ou estados tendo em vista uma meta a ser atingida. Scripts são planos altamente convencionalizados, pelo fato de serem utilizados com grande freqüência para desempenhar certos papéis ou exercer determinadas funções, sendo, por isso, estereotipados mesmo em termos de linguagem. Cenários são modelos que descrevem o 'domínio estendido de referência', usados na interpretação de textos escritos, já que, segundo Sanford \& Garrod (1981), 'pode-s pensar o conhecimento de
} 
remetem à idéia de estruturas que abarcam modos de acontecimentos baseados em experiências sociais e culturais;

3) Conhecimento procedural ou procedimental que depende de aspectos sociais e que se referem a procedimentos, ou seja, determinadas ações aceitas em determinados contextos. Além disso, está relacionado à inserção de um indivíduo em uma sociedade cultural e a um grupo social, no qual este sujeito cresceu e vive;

4) $\mathrm{O}$ conhecimento ilocucional refere-se à capacidade de se inferir os objetivos ou tipos de objetivos ou tipos de atos de fala do interlocutor;

5) $\mathrm{O}$ conhecimento comunicacional ou interacional ou de ação pode ser explicado de acordo os princípios de modalidade, quantidade, qualidade e relevância (GRICE: 1975) e possibilita, em uma situação comunicativa, aguardar por determinadas ações de nossos parceiros comunicativos, bem como ações que poderiam ter vindo à tona e outras que são inadequadas ou que ferem uma situação. Logo, é comum nos defrontarmos com divergências de conhecimento quando estamos em outros países, já que os conhecimentos de ação encontram-se em íntima relação com os fatores culturais de um país;

6) O conhecimento metacomunicativo é o trabalho que visa corrigir possíveis ações errôneas e que poderiam prejudicar o trabalho de compreensão por parte do interlocutor. É uma meta de segurança, já que através deste tipo de conhecimento o autor procura confirmar suas ações estrategicamente textualizadas;

7) O conhecimento de superestruturas ou de modelos cognitivos globais preconiza que o sujeito estabeleça critérios para levar em conta os diferentes gêneros textuais. Os sistemas apresentados acima se hierarquizam em conhecimentos ainda mais específicos. Estes, por sua vez, funcionarão como "filtro", para que um aparelho cognitivo seja formado na mente do sujeito.

contextos e situações como constituindo um cenário interpretativo atrás do texto'. Uma das funções da tematização no nível textual seria, assim, a de ativar um cenário particular para o leitor. Superestruturas são modelos cognitivos culturalmente adquiridos a respeito da estrutura global dos vários tipos adequados às diversas situações comunicativas. Tais modelos são construídos a partir de experiência, por meio da comparação 
A base conceitual de um texto encontra-se abaixo desta estrutura superficial, denominada estrutura profunda ${ }^{6}$. Esta se apresenta como multidimensional, na qual as diferentes unidades de informação serão conectadas por meio de modos complexos. Os interlocutores organizam o texto por meio de relações e, onde elas não existem, são construídas a partir de pressuposições oriundas das representações textuais cognitivas. Assim, ordena-se e interliga-se o texto de acordo com seus conhecimentos seguindo, mesmo quando uma outra ordem é observada na superfície textual.

De acordo com estas asserções, processar um texto significa textualizar (KOCH: 2003, 2004) um objeto real de acordo com convenções sócioculturais. Assim, o referente textual estende seus domínios aos campos cognitivos, apreendidos a partir de experiências cotidianas e interacionais. O processo de referir considera os elementos presentes no texto nas relações textuais e cognitivas, assim como numa situação sociointeracional. Estes objetos são passíveis de recategorização de acordo com diferentes contextos ou pontos de vista (KOCH: 2004). Evocando-se os estudos de Reichler-Béguelin (1995), nota-se que a referência é um processo desencadeado na medida em que o texto é desenvolvido.

De acordo com van Dijk (2002), há esquemas cognitivos que norteiam os comportamentos verbais em determinado contexto. Não obstante, considera o conceito de frame institucional, ou seja, amplamente conhecidos e distinguidos de acordo com a situação comunicativa. Sem ele, o processo de interpretação dos enunciados é árduo e de difícil execução. Os meta-frames remetem à idéia de adequação dos atos de fala ao contexto comunicativo. O conhecimento destes elementos possibilita mais êxito no processo de produção e compreensão textuais, já que preconiza a esquematização do conhecimento de mundo, ou seja, saber o que significam objetos abstratos ou concretos e aplicá-los a

e da diferenciação dos textos. Segundo van Dijk (1983), uma superestrutura contém (macro)categorias e regras de formação (ordem possível em que as categorias ocorrem no texto)".

${ }^{6}$ Os conceitos de estrutura superficial e estrutura profunda foram confeccionados a partir dos apontamentos apreendidos em LINKE, A; NUSSBAUMER, M. \& PORTMANN, P. R. Textlinguistik. In: Studienbuch Linguistik. Tübingen: Niemeyer, 1994 (pp.: 212-256). Segundo os autores, a estrutura superficial é a representação de unidades de informação do texto realizadas lingüisticamente e que são ligadas por meio de operadores coesivos. Estas estruturas superficiais dão-se através de uma natureza linear da nossa produção e produto lingüísticos. Por outro lado, afirma-se que a base conceitual de um texto encontra-se abaixo desta estrutura superficial, denominada estrutura profunda, que se apresenta como multidimensional e onde as diferentes unidades de informação serão interligadas por meio de modos complexos. 
determinados planos de ação, tornando-os, assim, proposições. Estas não transmitem a descrição de um objeto, mas seu estado.

Os conhecimentos ativados no ato da leitura têm ligação com outros textos e informações anteriormente armazenados na memória do interlocutor. A macroestrutura (van DIJK: 2002) baseada nos sentidos veiculados pelo autor é passível de conflitos com o conhecimento de mundo do receptor. Este se vê diante da opção de buscar os significados fazendo uso de um instrumento agregador, no caso, o computador. É a passagem do conhecimento declarativo, baseado em eventos e fatos reais, para o conhecimento procedural ou procedimental, culturalmente determinado e ativado na interação verbal (FÁVERO: 1989). O conceito de coerência baseia-se, portanto, em dois pressupostos: o papel da experiência individual, embasada nas hipóteses formuladas entre o texto e o conhecimento de mundo e a construção recíproca de imagens entre os interlocutores e suas respectivas necessidades comunicativas.

Linke, Nussbaumer \& Portmann (1994) afirmam que os esquemas de conhecimento possibilitam as pressuposições quando da interação textual. O conceito de pressuposição procura explicar a função dos conhecimentos extralingüísticos na constituição da coerência textual. De acordo com os autores, as pressuposições são ativadas no uso (gebrauchsgebundene Prässupositionen) em uma determinada situação, remetem a formulações não-lingüísticas, mas que são condicionadas no texto devido a um conhecimento e experiências cotidianas. Daí, serem chamadas de pressuposições pragmáticas. Quando o interlocutor comunica-se, parte de um conhecimento cotidiano ou científico, ou seja, de experiências, valores e conhecimentos gerais. Estas pressuposições ativadas no uso da língua também são representadas por aquelas condições que são firmadas entre os interlocutores, quando uma expressão é empregada em uma situação concreta de comunicação ${ }^{7}$.

Assim, a função de dar coerência a partir das pressuposições sugere que dois estados de coisas indiretamente ligados por meios expressos, sintáticos e de conteúdo são suficientes para afirmar que as estruturas do texto não são suficientes para a interligação dos sentidos e

\footnotetext{
${ }^{7}$ Diferentemente das pressuposições, consideradas como correntes de estruturação dos textos, com as quais é possível ligar frases e excertos textuais, os modelos de conhecimento abrigam em seu interior expressões e enunciados inerentes a um texto, os quais podem ser alocados em qualquer lugar deste modelo, desde que pertençam a ele (LINKE, NUSSBAUMER \& PORTMANN: 1994).
} 
implicações entre os elementos textuais, mas sim, as interpretações semânticas em um contexto significativo. A fim de ativar meios para a reatualização de sentidos em um texto, o conhecimento pressupõe a construção da coerência textual, fazendo com que o texto readquira seu caráter comunicativo e fazendo dele um objeto instável e passível de atualizações. Estes processos são reconhecidos de acordo com a natureza das informações utilizadas.

A relação, tanto semântica quanto estrutural, entre os elementos textuais é reflexo de concepções de pensamento que agem sobre a realidade vivida pelo interlocutor, que tece minuciosamente as relações de significado em estruturas complexas que transmitem conhecimento através de uma semiose denominada texto.

O estudo do texto à luz de teorias sóciocognitivas pressupõe a existência de fatores que abrangem não somente a materialidade discursiva, mas também seus aspectos cognitivos e pragmáticos. O texto é, portanto, uma ferramenta semântico-estrutural e que abriga em seu interior estruturas de menor escala e que, quando justapostas, sofrem reduções semânticas a fim de dispor o texto como uma proposição semântica unitária ou com um perfilamento de unidades temáticas que apresentam elementos semanticamente uniformes (van DIJK: 2002; KOCH: 2003).

Daí, o estudo dos sentidos ocupar um posto relevante no âmbito da análise de textos. Os sentidos extrapolam os limites estruturais, sendo que há uma reciprocidade entre estrutura e sentido, pois a evocação de ambos no estudo do texto é mútua e dependente. É latente, portanto, a necessidade de se observar como os sentidos comportam-se na estrutura textual, ou seja, a organização, desenvolvimento e manutenção estratégica (caráter pragmático da linguagem) dos sentidos circulantes em um texto.

\subsubsection{Os fatores de textualidade}

De acordo com os apontamentos de Beaugrande \& Dressler (1981), há sete critérios ou princípios de textualidade: 
- A coesão textual é reconhecida, em primeira instância, pela articulação de elementos existentes na superfície textual. O diferencial proposto pelos autores é a formação de uma coerência entre os enunciados, superiores à frase. Halliday \& Hasan (1991) argumentam que a referência, a substituição, a elipse, a conjunção e a coesão lexical denotam a classificação de coesão. Devido a críticas a esta hierarquia formuladas por Koch (2003, 2004), passou-se a considerar dois grupos: a referência ou remissão (coesão referencial/ remissiva) a elementos anteriores e a seqüência do texto (coesão seqüencial). Os autores subdividem a coesão lexical em reiteração e colocação. Ressalta-se, ainda, que a coesão referencial abrigava em seu interior os efeitos de anáfora e da catáfora, que ajudam na progressão do texto.

- A coerência, para os autores, subjaz à superfície textual, onde se configura a veiculação de sentidos.

- A situacionalidade, considerada de modo decrescente, ou seja, da situação para o texto, diz respeito aos fatores situacionais que sugerem que um determinado texto é mais adequado e outro não. No movimento ascendente, considera-se a reconstrução do mundo a partir do texto, no qual ambos são divergentes. "Ao construir um texto, o produtor reconstrói o mundo de acordo com suas experiências, seus objetivos, propósitos, convicções, crenças, isto é, seu modo de ver o mundo" (KOCH, 2004, p. 40).

- As propriedades de distribuição e previsibilidade norteiam os estudos da informatividade. A primeira diz respeito ao movimento dado-novo, no qual um texto somente com informações dadas não pode ser considerado como tal e é dotado de circularidades discursivas. Um texto elaborado somente com informações novas é improcessável, já que o interlocutor não tem como inferir significados a partir de seus esquemas mentais. A propriedade da previsibilidade concentra-se no quanto o interlocutor pode inferir de um texto a partir de seu conhecimento de mundo. O texto é informativo como um todo, mas esta característica é classificada em graus, ou seja, um texto pode ser mais ou menos informativo. No entanto, isto também é dependente dos interlocutores e não é 
algo que está estritamente centrado no texto. Por outro lado, a maneira como a informação é relacionada textualmente opera para que este aspecto esteja relacionado à estrutura textual.

- A intertextualidade refere-se ao conhecimento de tipos/gêneros textuais que têm os falantes.

- A partir dos estudos textuais à luz da pragmática, passou-se a argumentar que o texto provém de motivações, o que remete à intencionalidade.

- Por outro lado, o autor deve fazer com que seus objetivos sejam compreendidos pelo seu interlocutor, o que leva ao conceito de aceitabilidade. É a resposta positiva do interlocutor em integrar um jogo ativo de sentidos (princípio da cooperação). De acordo com Marcuschi (1983), o co-texto e a situação comunicativa desempenham papel fundamental na textualidade. Para o autor, marcas ao redor do texto e fatores de contextualização promovem inferências na mente do interlocutor.

- Consistência e relevância preconizam a não-contradição e a adequação dos enunciados ao tema proposto no texto.

- A focalização concerne ao trabalho dos interlocutores de parcelar seus conhecimentos em um assunto. Assim, divergências com relação a esta propriedade podem causar má compreensão no momento da interação com o texto. "A focalização permite determinar, também, o significado, no texto, de palavras homônimas e polissêmicas, bem como o uso adequado de certos elementos lingüísticos de valor dêitico, como é o caso dos verbos ir e vir, cujo emprego depende da direção do movimento focalizado. A focalização é, ainda, responsável pela escolha de descrições ou expressões nominais, na construção/ reconstrução de referentes textuais" $(\mathrm{KOCH}, 2004$, p. 45).

- Conhecimento partilhado é o negociado no momento da interação com o interlocutor (cf. acima, a questão da problemática cognitiva no que diz respeito 
à separação corpo/ mente). O texto é uma reconstrução discursiva do mundo, na qual os elementos são textualmente elaborados. No entanto, este processo depende do agir sobre o mundo que, por sua vez, é idiossincrático.

O texto, portanto, é elaborado a partir de mecanismos complexos que fazem de um grupo ordenado de palavras um arcabouço de sentidos. $\mathrm{O}$ estudo do escopo semântico do texto remete à busca pela sua origem não somente em seus componentes, mas na geração deles, o que estabelece relações de produção textual com aquilo que se enxerga e tenta-se ressignificar (KOCH: 2004). Um destes operadores complexos que abarcam tanto a parte material quanto cognitiva da atividade verbal, considerado acima como um dos fatores de textualidade, é denominado coerência textual. Logo,

O produtor do discurso fornece tantos índices quantos julga necessários para transmitir plenamente o que quer dizer, apoiando-se para isso em hipóteses em relação a quanto o interlocutor pode deduzir de seu discurso. Se suas hipóteses são boas, o interlocutor poderá reconstituir o que ele quis dizer baseando-se nos índices que forneceu e referindo-se a um saber comum entre os dois. Isso não implica que o que o emissor criou e o que o receptor recriou sejam necessariamente a mesma coisa (BASTOS, 1985, p. 11).

\subsubsection{A coerência textual}

Os estudos de coerência, que anteriormente era estudada juntamente com a coesão (análise transfrástica), trouxeram ganhos fundamentais para o desenvolvimento dos estudos da Lingüística Textual. A partir do momento em que os sentidos passaram a ser detectados não mais estritamente no texto, os pressupostos sóciocognitivos ocuparam em grande parte os estudos textuais. Os aspectos lingüísticos passaram a ser observados em conjunto com operações de ordem cognitiva, social e interacionista. Com efeito, como colocado acima, outros fatores passaram a fazer parte das características essenciais de um texto: informatividade, situacionalidade, intertextualidade, intencionalidade, aceitabilidade, contextualização, focalização, consistência e relevância (estes quatro últimos advindos de estudiosos da pragmática). Daí a necessidade do estudo aprofundado dos processos cognitivos. A produção e compreensão textuais, os modelos de cognição, os sistemas de 
conhecimento etc., bem como as questões relativas ao processo de interatividade, passaram a predominar na cena acadêmica referente à lingüística textual.

Assim, a partir da década de 90, além da ênfase dada aos processos de organização global dos textos, assumem importância particular as questões de ordem sociocognitiva, que englobam temas como referenciação, inferenciação, acessamento (sic) ao conhecimento prévio etc.; e, a par destas, o tratamento da oralidade e da relação oralidade/ escrita, bem como o estudo dos gêneros textuais [...] $(\mathrm{KOCH}, 2003$, p. 44).

A coerência vem sendo amplamente considerada ora em seus aspectos cognitivos, ora em seus aspectos textuais. Os estudos que vêm se desenvolvendo a partir da década de 60, quando do início da Lingüística Textual, preconizaram análises que se concentraram tanto na discussão teórica dos fenômenos cognitivo-textuais quanto em dissecações textuais práticas, comumente alocadas no nível frástico do texto. A partir disso, verificam-se duas problemáticas, assim consideradas devido ao avanço dos estudos textuais, que se complementam em um estudo: a coesão, tomada aqui como a manifestação lingüística dos sentidos, e a coerência, ferramenta cognitiva que prima pela focalização, delimitação e derivação de elementos relevantes para um determinado texto (KOCH: 2004). A coesão, por fim, remete à estrutura textual e a organização dos níveis lingüísticos em geral; a coerência às proposições, verossimilhança e aos atos ilocucionais. No entanto, a coerência depende dos interlocutores. O receptor deve ter habilidades (conhecimento de mundo e lingüístico) para compreender um determinado texto de modo íntegro e, conseqüentemente, coerente. Logo, “[...] a coesão não é a causa da coerência, é o seu efeito; um texto coerente será muito provavelmente coeso, não por necessidade, mas como resultado de sua coerência" (BASTOS, 1985, p. 15). Nesta linha de pesquisa, a frase coloca-se não como unidade hierarquicamente superior e também não se considera o texto como grupo frasal semântico.

Inicialmente, ambos eram confundidos quando da análise transfrástica (KOCH: 2003). De acordo com a evolução dos estudos textuais, elas passaram a se diferenciar. Primeiro, com os estudos da semântica textual, nos quais a coerência foi mostrada do ponto de vista de profundidade do texto, ao passo que a coesão refere-se à superfície textual. Por outro lado, confirmou-se que as operações coesivas imprescindem dos efeitos de sentido, construindo-se, desta maneira, em dependência da coerência. Não obstante, a progressão textual e as expectativas sobre o texto dão-se de maneira crescente e decrescente, de modo que as estruturas estão em constante dependência dos sentidos. No estágio seguinte de pesquisas, a 
pragmática voltada para a lingüística textual concentrou-se na intenção e na formulação de um plano geral baseados na teoria dos atos de fala. Daí, a idéia de coerência ser elaborada de acordo com processos interativos e operações cognitivas influenciadas pelo contexto comunicativo. Depois disso, as contribuições oriundas da vertente sóciocognitivista afirmaram que a coerência é negociada permanentemente pelos interlocutores, de modo que o mundo ali textualizado é único e construído a partir das experiências dos sujeitos falantes.

De acordo com Koch $(2003$, 2004), a coerência textual é, primeiramente, a interdependência semântica entre as unidades textuais. É a tessitura de sentidos elaborada a fim de tornar o texto verossímil e compreensível para o interlocutor por meio da articulação entre coerência local e global (van DIJK: 2002). Por coerência local, compreende-se aquilo que foi denominado coesão, ou seja, a articulação de elementos textuais naquilo que é aparente no texto. Gramatical por excelência, esta definição de coesão remetia aos fenômenos de referenciação e remissão (KOCH: 2004), que abarcam a estrutura do texto. No entanto, os objetos presentes no texto são referências a objetos de mundo e são atualizados de acordo com o conhecimento dos interlocutores, além da existência de uma realidade social que valide a textualização operada pelo autor.

Coesão é uma relação semântica entre dois elementos, sendo ela crucial para a interpretação. No entanto, a textualidade não depende somente disso, mas também da coerência, que é definida por meio dos moods, que são formas de influência no falante na situação discursiva. Assim, um texto é um produto do discurso e que tem dois aspectos: é coerente na situação na qual foi enunciado e coeso em sua estrutura (HALLIDAY \& HASAN: 1991). A textualidade resulta, então, do registro e da coesão. Registro remete à idéia da integralidade, do sentido geral do texto, aquilo que ele representa em determinada situação comunicativa, incluindo aí todos os componentes sociais. Já a coesão é compreendida de acordo com uma série de características gerais relativas a todos os textos e que distinguem os textos dos não-textos. Ela remete à idéia da construção, ou seja, o que o texto está construindo em termos semânticos.

Ainda segundo os trabalhos empreendidos por van Dijk (2002), há que se distinguir duas espécies de coerência: a condicional e a funcional. Opinião semelhante tem Bastos (1985) a respeito da coerência, diferindo os conceitos de coerência microestrutural e coerência macroestrutural. 
A coerência condicional ou microestrutural dá-se em nível frástico e é estabelecida de acordo com a necessidade de se continuar proposições, como na relação causa e conseqüência. É a coerência que denota uma seqüência de fatos. Prescreve-se que algo resultará em alguma coisa e, condicionalmente, haverá relações entre as seqüências. Isso leva a crer, portanto, que as proposições devem ser colocadas de maneira que os sentidos sejam condicionados ou moldados.

Em outras palavras, certos julgamentos de coerência dependem das convicções do receptor sobre certos aspectos do mundo interpretado, sendo que esse sujeito-receptor sabe que o texto que interpreta ou avalia é um processo de emissão específico, centrado sobre um assunto inscrito numa situação precisa da qual pode, ou não, conhecer certos componentes. Charolles reconhece, assim, que [a coerência microestrutural] está sujeita a aspectos da situação de comunicação e que, na realidade, sozinha, não dá conta das condições que um texto deve satisfazer para ser considerado como bem formado e não é suficiente para explicar os fatos relativos a um texto (CHAROLLES, cit por. BASTOS, 1985, p. 8).

No que diz respeito à coerência funcional ou macroestrutural, as proposições são independentes e dizem respeito às seqüências enunciativas e ao mesmo referente. Não há cumplicidade estrutural entre ambas, de modo que há função semântica tácita estabelecida e dependente entre as proposições. Parece, no entanto, que a coerência condicional existe a partir de conectivos de diversas naturezas, ao passo em que a funcional opera sem objetos da linearidade discursiva, mas sim, na profundidade semântica e nos preceitos de coordenação e subordinação frasais. A coerência funcional revela-se, de acordo com as nomenclaturas propostas por $\mathrm{KOCH}(2003,2004)$, como coerência, ao passo em que a coerência condicional concerne aos operadores de coesão do texto.

Segundo Linke, Nussbaumer \& Portmann (1994), as pressuposições ativadas nos signos correspondem à coerência condicional e são ramificadas em dois grupos. O primeiro deles abriga as pressuposições referenciais ou existenciais, que se revelam nas formas de expressões lingüísticas e aparecem nas superfícies frásticas. O segundo grupo dirige-se às pressuposições semânticas que se ligam a palavras ou expressões. Trata-se aqui de um modo indireto de exteriorização, mas com significados em conjunto. Ambos os tipos de pressuposições ativadas no signo permite que os interlocutores afirmem determinadas expressões que estão conectadas indiretamente às tematizações correntes, isto é, às expressões implícitas. No entanto, algumas 
demonstrações levantam discussões pertinentes sobre as pressuposições referenciais e semânticas.

As pressuposições semânticas não se prendem integralmente às estruturas e ao conteúdo de um enunciado, mas são elaboradas de acordo com o conhecimento dos interlocutores. No entanto, não são tão amplas como as pressuposições pragmáticas e, por isso, ainda se encontram condicionadas à expressão. Logo, pode-ser afirmar que a coerência é desencadeada a partir de tentativas de preenchimentos textuais envolvendo, portanto, operadores estruturais e semântico-textuais.

Assim, a coerência textual responde ao processamento textual que envolve elementos subjacentes ao texto, na qual "[...] o processamento de sentido é feito a partir de conhecimentos sócio-culturalmente adquiridos, de operações lógicas, do contexto (situacional e lingüístico) e da vivência do dia-a-dia" (KOCH, 1988, p. 157). No entanto, estes diversos conhecimentos dão-se somente na interatividade e, portanto, na legibilidade, onde os interlocutores encontrarão a possibilidade de medir seus respectivos conhecimentos de mundo e dar coerência ao texto, já que "[...] compreender envolve não somente o processamento e interpretação de informações exteriores, mas também a ativação e uso de informações externas e cognitivas" (van DIJK, 2002, p. 15). O trabalho de compreensão textual abarca não somente a produção e circulação de sentidos elaborada pelo autor, mas envolve a atualização de significados que desencadearão a sintonia entre os interlocutores, ou seja, a busca pela coerência. A incorporação de sentidos a um determinado texto é norteada pela intertextualidade, já que as relações construídas pelo interlocutor dependem da busca por sentidos estabelecidos em outros textos. Assim,

A coerência pode ser vista também em termos da competência textual dos usuários da língua. A competência textual vista não somente como a capacidade de analisar e interpretar os atos comunicativos, mas também como a capacidade de produzir enunciados coerentes, que se prestem aos propósitos de comunicação. O receptor somente decodificará/ entenderá coerentemente um enunciado quanto maior for sua competência para tal, e tanto mais quanto for a competência do emissor na elaboração de seu discurso prevendo os conhecimentos de seu interlocutor (ARAÚJO, 2000, p. 131).

O estudo das relações subjacentes à superfície textual e desencadeadas a partir do texto envolve pesquisas sobre a construção textual do conhecimento e sua respectiva organização. 
Toma-se o texto como o resultado de uma atividade sóciocognitiva da linguagem, visto que o conceito de coerência aqui observado delimita-se aos processos de textualização de conhecimentos e às estruturas temáticas do texto. De acordo com Linke, Nussbaumer \& Portmann (1994), a coerência dá-se em termos textuais e nas acepções cognitivas. A busca pela compreensão de textos é a tentativa do interlocutor de estabelecer relações entre os elementos que compõem este produto sóciocognitivo. Estas relações atrelam-se tanto à superfície textual, observada por meio dos estudos de coesão, quanto aos sentidos subjacentes ao texto, esmiuçados pelas problemáticas relativas à coerência textual.

Em uma observação panorâmica, quando o recipiente e o produtor do texto discorrem acerca do mesmo conhecimento de mundo e da mesma experiência, não haverá maiores problemas para o recipiente quando dos processos pressuposicionais no esquema interpretativo. Este gerenciamento de completude é automático e inconsciente. Naturalmente, há casos em que os recipientes vêem-se diante da insuficiência de conhecimentos a fim de almejar a totalidade das pressuposições e, conseqüentemente, este sujeito não terá como elaborar sua argumentação. Nestas situações, o recipiente deve construir interligações semântico-textuais ${ }^{8}$, com o objetivo de fazer do texto coerente e compreensível.

Desta maneira, considera-se coerência como um processo que se encontra em constante mutação, pois é circunscrita aos recortes de realidade e à experiência dos interlocutores no mundo. Os conhecimentos advêm de enquadramentos oriundos da realidade na qual vive o interlocutor. Desta feita, as diferentes abordagens acerca do conhecimento, que podem ser resumidas em conhecimento lingüístico, de mundo e partilhado (ARAÚJO: 2000) são culturalmente determinadas e compartilhadas. A atribuição de sentidos ao texto é provida por interlocutores socialmente ativos, o que justifica o fato de a coerência ser dada a partir do texto e não nele. Tais acepções vão de encontro às pesquisas empreendidas por Brown \& Yule (1983), que afirmam que os aspectos contextuais são diretamente refletidos no texto e podem ser denominados de características ativadoras de contexto ${ }^{9}$. Este processo de adequação elenca diferentes tipos de conhecimento. O texto, portanto, é uma unidade formada por proposições semântico-comunicativas, agrupadas em segmentos fortemente interdependentes (HALLIDAY \& HASAN: 1991).

\footnotetext{
${ }^{8}$ Textzwischenstücke.

${ }^{9}$ Activated features of context.
} 
Seqüências de sentenças expressam seqüências de proposições. Para isso, é crucial que o interlocutor estabeleça conexões entre proposições e entre suas seqüências, para que um mundo discursivo seja elaborado. Assim, há que se estabelecer uma hierarquia semântica nestas seqüências proposicionais, já que o discurso é também uma ordem de sentidos.

Desta maneira, a coerência existe em um texto quando da harmonia entre o aparecimento e identidade de referentes e o relato de fatos possíveis no mundo. Não se pode a restringir ao âmbito semântico, mas alicerçá-la aos pressupostos pragmáticos (afirmar, exemplificar, sugerir, ordenar etc). No caso dos conectivos, aquilo que a gramática denomina de adição pode se tornar um ato de fala irônico, na situação, por exemplo, de alguém contar um fato e seu interlocutor responder a isso com um "e" alongado. É claramente uma pista de compreensão do ato de fala do locutor e a sua resposta a isso, através de uma outra seqüência pragmática.

Assim, a coerência é um processo desencadeado quando do uso comunicativo da língua, no qual a interatividade mostra-se com um aspecto que negocie as relações semântico-textuais propostas pelos interlocutores. A continuidade de sentidos é concomitante à produção textual e está relacionado ao conhecimento de mundo e ao aspecto pragmático da língua. Logo, podese afirmar, segundo Araújo (2000), que a coerência dá-se nas experiências individuais, bem como na sociedade, exercida de acordo com a influência recíproca entre os falantes. Portanto, “[...] a coerência é relativa ao conhecimento de mundo, tanto do conhecimento do falante quanto do ouvinte, ou seja, ela depende tanto dos conhecimentos prévios dominados pelos interlocutores quanto dos conhecimentos partilhados entre ambos (ARAÚJO, 2000, p. 136).

De acordo com o que foi colocado, nota-se que há dois tipos de coerência, os quais estáticos e processuais, de modo que o primeiro refere-se aos aspectos de coesão, ao passo em que a segunda espécie diz respeito ao texto como unidade hierárquica de sentidos. Essa diferenciação deu-se, como esclarecido, de acordo com o desenvolvimento dos estudos do texto. Desta maneira, as pesquisas oriundas do sóciocognitivismo possibilitaram a observação de que a coerência é um processo orientado de acordo com modelos cognitivos, compartilhados por uma determinada sociedade e ativados quando de uma situação comunicativa entre dois ou mais interlocutores. 
Nota-se que esta partilha lingüística não envolve necessariamente seres físicos, mas a partir de configurações esclarecidas a partir dos fatores de textualidade (de BEAUGRANDE \& DRESSLER: 1981), vê-se que as imagens mentais formuladas pelos interlocutores permitem vislumbrar a aceitabilidade e, conseqüentemente, a produção e a recepção de textos a partir de estereótipos regulados pelo conhecimento partilhado entre os interlocutores.

Assim, a coerência considerada como um processo orientado (STORRER: 2002) ramifica-se em dois aspectos relacionados ao perfilamento de sentidos em um texto, os quais, a sua construção e design ${ }^{10}$. O primeiro diz respeito a modelos de compreensão textual, ou seja, procura explicar como os interlocutores elaboram teias de conhecimento a partir de interferências lingüísticas e não-lingüísticas no momento da interação comunicativa. Já o design da coerência está centrado na produção de textos e procura descrever as operações estratégicas a fim de promover a compreensão textual. Nota-se, portanto, que os processos complementam-se, de forma a esclarecer a problemática da produção e recepção de sentidos entre interlocutores que atualizam textos de maneira divergente.

A produção textual possibilita a criação de uma representação mental da superfície do texto $^{11}$, que diz respeito às suas palavras e propriedades formais; uma base proposicional ${ }^{12}$, apreendida a partir da sintaxe e da semântica das proposições do texto e, por fim, um modelo mental do conteúdo do texto ${ }^{13}$ (STORRER: 2002), gradativamente processado pelo interlocutor em conjunto com o conhecimento prévio e com as informações já dadas no próprio texto. Assim, o processamento textual

[...] é descrito como um interjogo entre as proposições processadas permanentemente na base do texto, o modelo mental construído a partir disso e o conhecimento prévio agindo no foco de atenção momentâneo. Ao decorrer deste processo, o modelo textual-cognitivo gradualmente torna-se mais elaborado e detalhado (SCHNOTZ, cit. por STORRER, 2002, p. 6) ${ }^{14}$.

A partir da asserção de que o modelo cognitivo torna-se mais elaborado, pode-se afirmar também que há gradações de coerência, já que estes modelos podem ser mais ou menos

\footnotetext{
${ }^{10}$ Coherence-building e Coherence-design.

${ }^{11}$ Mental representation of the surface text.

12 Propositional text base.

${ }^{13}$ Mental model of the text content.
} 
sofisticados. Depreende-se, portanto, que a coerência está estritamente relacionada com modelos cognitivos e textuais e depende deles para existir, fazendo com que ela seja calculada de acordo com a complexidade destes modelos. Estes modelos concernem a esquemas cognitivos, definidos como conexões de conhecimentos oriundas de experiências e da combinação de conhecimento declarativo e procedimental, posteriormente transformados em unidades funcionais. Estes esquemas cognitivos são representados por frames ou scripts (STORRER: 2002). A evolução destes modelos cognitivos advém do embate entre a base proposicional e os modelos mentais já armazenados na mente do interlocutor. No que diz respeito ao design da coerência, deve-se atentar para dois aspectos que promovem a uniformidade de sentidos quando da produção textual: a organicidade tópica e a concorrência com padrões convencionais de textos, ou seja, superestruturas (SCHNOTZ: 1994; van DIJK: 2002).

A representação semântica tem início no conjunto de sentenças e conexões das mesmas, nas quais as relações devem ser estabelecidas para que os sentidos possam ser veiculados uniformemente, originando as pressuposições e suas seqüências. Conseqüentemente, estas conexões também devem se dirigir às pressuposições formuladas pelo interlocutor, já que a memória episódica culturalmente compartilhada abre espaço para questionamentos acerca do texto.

O conceito de esquema (van DIJK: 2002) diz respeito às configurações de texto presentes na memória do interlocutor, ou seja, refere-se às estruturas nas quais os sentidos alocar-se-ão. As superestruturas são culturalmente compartilhadas e, portanto, auxiliam na compreensão de um texto a partir de orientações estruturais que visam a adequação e ressignificação de sentidos. Assim, apreende-se que o processo de interlocução textual não passa somente por aspectos cognitivo-textuais, mas também por dimensões calcadas em fatores estruturais que atuarão como escopos semânticos idiossincráticos, ou seja, referentes a todos os tipos de textos conhecidos em uma sociedade. Desta forma, tem início o processo de atualização textual, já que as formas orientam, de antemão, os processos de interlocução, firmando-se como uma das características intermediárias que apóiam o trabalho textual (LINKE, NUSSBAUMER \& PORTMANN: 1994).

\footnotetext{
${ }^{14}[\ldots]$ is described as an interplay between the propositions in the text base that are currently processed, the mental model built so far, and the background knowledge in the current focus of attention. In the course of this process, the mental model of the textual world gradually becomes more elaborate and detailed.
} 
Ampliando a questão, é possível observar que, além da coerência entre proposições, há também o conceito de macroestrutura (van DIJK: 2002). A macroestrutura é reconstruída a partir daquilo que se propõe ao longo de um texto, de modo a fazer uso de regras que resultam nas proposições atômicas mais relevantes para os interlocutores. Define-se, portanto, a coerência global. Ao contrário de uma simples soma, a macroestrutura é o resultado de uma mutabilidade constante entre as propriedades de coerência local. Assim, há uma implicação semântica entre as proposições, de modo que o grau de maior abrangência dos sentidos origina-se destas implicações, o que resulta em uma linha interpretativa comum a todas as proposições. Trata-se de uma coerência global, que unifica e uniformiza os sentidos de um texto. O mecanismo para definição das propriedades mais relevantes de um discurso é denominado macrorregra. "As macrorregras suprimem toda informação proposicional de relevância exclusivamente local que não seja necessária para a compreensão do resto do discurso" (van DIJK, 2002, p. 52). Elas são divididas em (van DIJK, cit. por COMASSETTO, 2001, p. 23):

- Omissão: a partir de critérios orientados pela relevância, o interlocutor exclui proposições consideradas irrelevantes no que se refere ao texto;

- Generalização: relacionada aos referentes e a distribuição dos mesmos pelo texto, esta macrorregra permite ao interlocutor retirar proposições elencadas a partir de um mesmo tópico discursivo e que não o tratem de maneira diferenciada;

- Construção: é o aglutinamento de proposições que se encontram segmentadas de acordo com predicações condizentes ao mesmo referente sendo, portanto, passíveis de reconstrução em uma proposição somente, que abarque as derivações e extensões do referente antes espalhado pelo texto.

Ainda na esteira das relações entre texto e coerência, aporta-se no que van Dijk (2002) denomina de processos e estratégias globais de interpretação do texto. Este processo dá-se tanto de maneira crescente quanto decrescente, já que o ato de ressignificação dos sentidos é geral e retroalimentativo caracterizando-se, portanto, como multilinear. As reciprocidades 
entre a coerência local e global, bem como entre superestrutura e macroestrutura, abrem caminho para a compreensão do texto, não sem o desígnio de hipóteses antecipadas por parte do interlocutor. Estas hipóteses, concretizadas de acordo com a relação entre proposições em nível local e, posteriormente, em nível global, tornam o trabalho de leitura, compreensão e interpretação multifacetado e orientado pela uniformização de referentes que se organizam de modo a delimitar as fronteiras cognitivas negociadas entre os interlocutores.

Estas delimitações semântico-textuais e a construção do texto por meio de proposições atendem às estratégias de produção, pois é a partir dos sentidos estabelecidos na interação que o escopo textual será circunscrito. Em vista disso, a produção do texto noticioso segue orientações que atuam de maneira minuciosa e que concerne à distribuição informativa. Cada jornal considera determinadas informações relevantes, adicionando ou emitindo informações consideradas fundamentais para a interpretação do texto noticioso. A superestrutura da notícia, portanto, elenca escopos a serem preenchidos pela macroestrutura noticiosa.

A notícia é um gênero discursivo, assim como todos os outros, que prima pelo equilíbrio entre o inédito, o desconhecido e aquilo que já faz parte do cotidiano do interlocutor. Assim, em textos que apresentam informações novas em demasia corre-se o risco de gerar desinteresse por parte do interlocutor, ao passo em que a falta de ineditismo faz com que o texto não tenha relevância e, portanto, não seja passível de leitura e interpretação. Desta feita, os esquemas cognitivos aqui formalizados por meio dos conceitos de frames e scripts, representam conhecimentos que são acessados por tópicos ou temas e não por palavras. De acordo com Sperber \& Wilson (cit. por DITTRICH, 2001, p. 63), as proposições de um texto estão diretamente relacionadas a "[...] dois mecanismos mentais: um módulo de entrada lingüístico e uma habilidade inferencial central [...] o que faz uma interpretação 'correta' e outra 'errada' é informação contextual'. Notam-se dois estágios quando da interlocução: em um primeiro momento, há decodificação; já em segunda instância desencadeia-se o processo de referenciação.

Assim, nota-se que o texto da notícia centraliza referentes de modo a construir um alinhamento semântico organizado a partir do princípio da relevância, ou seja, a partir da criação de novas circunstâncias que demonstrem ao interlocutor a importância de sua leitura (DINES: 1986). Esta contextualização dá-se, então, a partir de informações novas baseadas em eventos históricos de natureza semelhante, caracterizando a notícia como um trabalho de 
criação aspectual, de perspectivas, portanto, gerida de acordo com recursos semânticotextuais. A construção da representação semântica no texto noticioso é intermediada pelo elenco referencial e circunstancial, relacionando informações novas a informações já conhecidas pelo interlocutor. $\mathrm{O}$ estabelecimento da coerência textual, tomado aqui como equivalente ao conceito de trabalho textual (LINKE, NUSSBAUMER \& PORTMANN: 1994) diz respeito, portanto, à decodificação lingüística, à inferenciação e às circunstâncias criadas pelo jornal. O conhecimento do interlocutor é ativado e alterado a partir de proposições desconhecidas e que serão ancoradas em conceitos existentes em sua memória discursiva. Gradativamente, o texto torna-se compreensível e as perspectivas ali existentes são interiorizadas. A fim de facilitar este trabalho, o produtor apóia-se na equivalência entre tema e rema e, consequentemente, no princípio da relevância, já que é assim que os esquemas de conhecimento serão ativados e alterados.

A partir destas asserções, nota-se o papel do referente na produção e recepção de textos. Uma sentença pode suscitar no interlocutor um sem-número de representações semânticas e, portanto, de proposições. Este processo cognitivo dá-se na decodificação lingüística e na inferenciação cognitiva. Estas proposições, de acordo com a interlocução com o texto, ainda se encontram na categoria supositiva e, portanto, são construídas e alteradas constantemente de acordo com operações cognitivas que vasculham a memória do interlocutor a fim de procurarem um esquema de ancoragem. Como se trata de uma busca, as proposições mais relevantes em um texto serão aquelas que se caracterizam como modificadoras deste conhecimento e, desta forma, aquela que demanda menor esforço por parte do interlocutor. Logo,

[...] o conhecimento desse princípio orienta a escolha das expressões lingüísticas na organização da sentença. Isso pode ser estendido à relação de referência: o autor escolhe a expressão que considera ser a mais relevante para efeitos que quer produzir no interlocutor e, ao mesmo tempo, a mais facilmente processável (SPERBER \& WILSON, cit. por DITTRICH, 2001, p. 65).

Assim, na medida em que o interlocutor atribui sentido ao texto, apreende-se que há uma uniformidade semântica e, principalmente, informações desconhecidas por parte do interlocutor, o que atribui importância ao texto. Desta forma, afirma-se aqui que o processo de ressignificação do texto (KOCH: 2003, 2004) é orientado pela relevância, obtida através das imagens mentais que os interlocutores possuem uns com relação aos outros. O texto e, 
portanto, também a notícia, é um produto argumentativo, pois pretende alterar os esquemas de conhecimento dos interlocutores. Não obstante, “[...] o conhecimento armazenado sempre é tido como verdadeiro e mantido como tal, até prova em contrário. Pode-se dizer que a verdade das suposições armazenadas é um axioma primitivo [...]” (DITTRICH, 2001, p. 66), observado como uma raiz a partir da qual espalham-se rizomas que operam os embates entre conhecimento prévio e informações novas, essas sendo incorporadas por meio das macrorregras descritas por van Dijk (1989). Logo, o uso argumentativo de determinadas proposições, orientadas por referentes e estados de coisas, não somente descreve determinados objetos e situações, mas é exprimido a partir de representações, o que garante a sustentação de pontos de vista, angulações e perspectivas.

\subsubsection{A macroestrutura do texto noticioso: o título}

Partindo-se dos pressupostos de van Dijk (2002), os quais preconizam que o texto noticioso é construído a partir de proposições que elencam referentes globais, verifica-se o papel de concentração e distribuição semântica presente na notícia. Desta forma, vê-se que há gradações de relevância de acordo com a produção do texto noticioso, segmentado em categorias que resultam na macroestrutura da notícia. Uma destas categorias revela-se em primeira instância na confecção do discurso noticioso: o título.

De acordo com Comassetto (2000: 32), “[...] Por sua posição estratégica e visibilidade, o título é a primeira categoria da notícia a fornecer o tópico que o interlocutor precisa para ativar um esquema mental". Assim, em primeira instância, o título mostra-se como um elemento referente à superestrutura da notícia localizada no seu topo. Logo, é o primeiro contato mediador entre o jornal e o seu público-leitor. Ao observar uma frase, curta na maioria das vezes, em conjunto com aspectos contextuais, o interlocutor é advertido de que está adentrando em um caderno informativo, no qual determinados aspectos de um acontecimento será comunicados. É uma estrutura que centra e organiza a notícia. Não obstante, suas configurações promovem a concentração dos olhares do interlocutor, pois é elaborada em fonte maior e destacada pela formatação em negrito. 
No que diz respeito ao seu papel semântico-textual, o título “[...] expressa a macroestrutura, pois, lido em primeiro plano, orienta a compreensão para a estrutura de relevância na apresentação das notícias" (GUIMARÃES, cit. por COMASSETTO, 2000, p. 40). Assim, retomando-se as definições propostas acerca do conceito de macroestrutura, apreende-se que a coerência, baseada na uniformização de referentes no decorrer do texto noticioso, tem início no título. A partir das macrorregras, o jornal concentra na proposição inicial da notícia desdobramentos semântico-textuais a ponto de se observar títulos curtos e, ao mesmo tempo, satisfatoriamente informativos para que o interlocutor prossiga ou não a sua busca informativa. Esta brevidade apóia-se em estratégias cognitivas de produção textual, já que neste momento serão ativados esquemas cognitivos de conhecimento na mente do interlocutor.

Desta feita, organiza-se um possível caos informativo acerca dos fatos (van DIJK: 2002), ao passo em que os referentes considerados relevantes a partir da ótica jornalística são elencados de antemão para que se estabeleça uma relação de reciprocidade e confiança. $\mathrm{O}$ jornal demonstra ao interlocutor de maneira global o que é relevante a partir da seleção de notícias, concretizada na formulação e disposição de títulos. Em consonância com o lead, que é definido de acordo com as premissas básicas do jornalismo, concretizadas nas informações básicas sobre um fato (o que, quem, quando, onde, como, por que e para que), o título aglutina os desdobramentos semântico-textuais a serem desenvolvidos no texto noticioso. Logo,

[...] Quando tratamos de macroestratégia de compreensão do discurso jornalístico, é indiscutível que a primeira categoria da notícia a ser observada é o título, embora seja ele, em regra, o último enunciado a ser produzido. Essa primazia na visibilidade determina que ele deve expressar a informação mais importante do texto, a macroproposição de nível mais elevado, que não só guiará a compreensão e a estrutura de relevância da representação da notícia na memória, mas também poderá ser decisiva para despertar o interesse pela matéria. Muitos leitores deixam de ler a notícia por não se sentirem atraídos pelo título ou por não verem relação imediata de seu conteúdo com as informações iniciais do texto (COMASSETTO, 2000, p. 36).

A partir destas considerações, avalia-se que o título caracteriza-se como uma macroproposição do texto noticioso, além de ser um encapsulador semântico. Em um movimento retroalimentativo, o jornal sugere ao interlocutor o acontecimento em uma proposição e, em contrapartida, o interlocutor tem a possibilidade de ter uma breve representação de um fato a partir do título ou manchete. Assim, é a partir deste processo 
interativo que o interlocutor apreende as informações suficientes não somente a fim de tomar conhecimento de um fato, mas também de se informar sobre ele e, fundamental, ser comunicado a partir de um determinado ponto de vista. "[...] o título, portanto, serve para dar equilíbrio estético à página, anunciar o fato, resumir a notícia e ativar fatores cognitivos que guiem a compreensão. É também pela importância que exerce na macroestrutura da notícia que ele aparece em corpo maior, comumente acima da matéria (COMASSETTO, 2000, p. 41).

As considerações aqui evidenciadas acerca do papel do título não somente no aspecto estrutural, mas também cognitivo-textual do hipertexto noticioso são necessários devido à forma de análise do corpus. Os hipertextos a serem analisados serão estudados a de seus respectivos títulos e links perfazendo, desta forma, uma continuidade de sentidos entre categorias semanticamente concentradoras. De acordo com os pressupostos tecidos acerca do link, nota-se que a comparação entre títulos e links é possível, já que ambos originam-se do nó informativo que, em conjunto com o link, caracteriza um hipertexto. Desta feita, discorreu-se acerca do título como uma macroproposição inicial e orientadora para que os escopos semânticos sejam preenchidos pelo esforço cognitivo-textual do interlocutor. Semelhantemente caracterizado será o link, já que se tratam de proposições ancoradas e existentes de forma não-linear.

Um texto é resultante de uma determinada escolha combinatória a partir de um semnúmero de opções possíveis. Esta definição, utilizada por Dittrich (2001), aborda a problemática da construção estratégica do texto noticioso, colocando os referentes como determinantes não somente como apontadores informativos, mas também como formadores de pontos de vista e, portanto, de interpretações. Assim, um hipertexto noticioso apresenta três momentos: construir uma circunstância, informar seus objetos e perspectivá-los. Destitui-se, portanto, o mito da objetividade jornalística, já que produzir um texto é abordar a realidade a partir de um determinado ângulo sustentado pelas experiências diretas e indiretas do interlocutor, bem como pelas práticas sociais que o circundam. Assim, os referentes no texto noticioso "[...] condensam a informação relevante e orientam a leitura na interpretação pretendida" (DITTRICH, 2001, p. 28).

Realizadas as devidas considerações acerca da coerência textual, parte-se para os estudos empreendidos a fim de esclarecer as problemáticas relacionadas à definição de 
hipertexto. Espera-se que os apontamentos feitos no âmbito da Lingüística Textual fundamentem, posteriormente, as análises operadas em hipertextos jornalísticos, de modo que se faça uma completude entre teorias advindas de pesquisas acerca de textos impressos e lineares.

Desta maneira, as asserções elaboradas em relação ao hipertexto não serão fruto de comparação direta com o texto tradicional, mas se deve levar em conta que foram elencadas as definições tanto de texto como de hipertexto. Assim, será possível observar como a coerência comporta-se em um texto suportado em um ambiente computacional, já que se considera nesta pesquisa o hipertexto como não-linear em seu aspecto técnico, porém passível de reatualização na sua característica textual.

Assim, as devidas observações serão realizadas a fim de discorrer sobre esta hipótese, de modo que, daqui para frente, comparações tácitas serão empreendidas entre o texto tradicional e o hipertexto. No capítulo referente ao papel dos links, estas comparações serão mais evidentes, já que se tentará demonstrar como estes links promovem a continuidade de sentidos em hipertextos jornalísticos brasileiros e alemães. Trata-se do estudo da produção textual em ambiente telemático e, assim sendo, as teorias advindas de textos impressos são perfeitamente cabíveis quando da pesquisa com corpus formado a partir de hipertextos.

\subsection{Considerações sobre o hipertexto}

O conceito de hipertextualidade é, atualmente, elaborado em conjunto com o seu suporte, no caso, a Internet. Entretanto, em primeira instância, a idéia de hipertexto procura solucionar o problema do excesso de informações e a referência cruzada de dados. Daí a tentativa de se elaborar algo acessível e que leve o interlocutor às informações que necessita. Enciclopédias e dicionários são os primeiros exemplos de textos estruturalmente não-lineares, nos quais os termos existentes são destacados e oferecem ao interlocutor facilidade. De acordo com este ideal, diversas tentativas de elaboração foram feitas até o formato de hipertexto atual. 
A evolução social do hipertexto remete às pesquisas de Dias (1999), que relata a história do hipertexto e analisa os seus efeitos sociais. Pauta-se em algumas mudanças paradigmáticas, no caso, a da linguagem, da escrita, da imprensa e do computador. Assim, evoca alguns símbolos que marcaram estas épocas até aportar no desenvolvimento do hipertexto. A interatividade e o compartilhamento de informações, ou seja, a multimídia, faz com que o hipertexto adquira características inéditas, que influenciam as sociedades de maneira divergente. $\mathrm{O}$ estabelecimento da rede mundial de computadores e o uso social dela refletemse na arquitetura hipertextual e, conseqüentemente, na forma e conteúdo destes textos recentes.

\subsubsection{Breve história do hipertexto}

Em 1945, Vannevar Bush, engenheiro americano e conhecido pelo seu papel político no desenvolvimento da bomba atômica, publicou um artigo na revista Atlantic Monthly intitulado "As we may think". Neste, o autor discorreu sobre um computador hipotético, o Memex, ligado a um extenso arquivo de microfilmes e apto a disponibilizar textos ou qualquer texto de uma biblioteca. De acordo com Nielsen (1995), seria usado um scanner para permitir ao interlocutor a inserção de materiais, o que também possibilitaria a elaboração de notas marginais. Assim, Bush descreveu o Memex como um dispositivo mecanizado em que uma pessoa guardaria todos os seus livros, fotos, jornais, revistas e correspondências e poderia consultá-los de forma rápida e flexível, como se fosse uma extensão de sua memória (DIAS, 1999, 272).

Era uma espécie de enciclopédia digital, a qual poderia até mesmo localizar um documento a partir da indicação por parte do interlocutor de apenas uma palavra. A idéia de Bush influenciou dois americanos que, futuramente, viriam a concretizar o hipertexto: Theodor Holm Nelson e Douglas Engelbart.

Nelson iniciou seus estudos na área da informação eletrônica em seu primeiro ano na Universidade Harvard. Sua primeira idéia foi criar um processador de palavras capaz de armazenar múltiplas versões de dados, inclusive mostrando-as. A partir disso, viu-se diante da necessidade de criar um instrumento capaz de uma escrita não-linear, armazenador de tudo o 
que fosse escrito e que disponibilizasse ao interlocutor a escolha de um caminho próprio. Assim, o projeto Xanadu era

[...] uma rede de informações acessível em tempo real, na qual existiria todo saber literário e científico do mundo, 'uma espécie de biblioteca de Alexandria de nossos dias'. Tudo isso estaria à disposição de qualquer pessoa para conectar-se, ler, escrever, comentar, interagir, estudar, não só no formato textual, mas também através da imagem e do som (CASTRO, 2001, p. 11).

Por outro lado, esse sistema de informação não poderia ser desenvolvido para computadores domésticos, dada a sua imensidão. No entanto, Ted Nelson considerava o hipertexto um meio literário, definição oriunda da observação de que tudo é interligado e, por isso, interagem entre si por meio de conexões online. Nelson cunhou o termo hipertexto, caracterizando a maneira como os dados eram organizados neste computador, ou seja, de modo a cruzar dados e ordená-los somente na medida da necessidade do interlocutor. Ele também criou os termos virtualidade e hipermídia.

Engelbart, americano descendente de noruegueses e inventor do mouse para computador, juntamente com Bill English, funcionário do Standford Research Institute e que posteriormente passou a trabalhar na Xerox, foram os pioneiros da interação entre computador e máquina. Ambos propiciaram o avanço com relação às pesquisas de Nelson e desenvolveu o primeiro hipertexto, assim como as redes computadorizadas e a interface gráfica de uso. De acordo com Nielsen (1995), a partir do ano de 1962, Doug Engelbart e seu grupo de pesquisa que contou com 45 pesquisadores, deram início aos trabalhos com o sistema de editoração Augument, desenvolvido pelo Stanford Research Institute. O intuito era desenvolver ferramentas computacionais para aumentar a capacidade e produtividade humanas. Uma parte deste projeto adveio do $N L S$ ou oN-Line System, o qual, apesar de muitas características hipertextuais, não foi assim desenvolvido. O Augument foi a primeira utilização técnica dos links na edição de documentos, possibilitando a interação entre o interlocutor e o computador. Ainda na década de 60, criou-se a Arpanet, rede embrionária da atual Internet e restrita ao Departamento de Defesa Norte-Americano, que contribuiu para o compartilhamento de informações entre trabalhadores envolvidos em projetos militares.

Entre os anos de 1967 e 1968 desenvolveram-se o Hypertext Editing System e o File Retrieval and Editing System ou FRESS, dois sistemas de hipertextos elaborados por Andries 
van Dam também na Universidade Brown. O primeiro foi o primeiro sistema de hipertextos no planeta que, em parceria com a IBM (International Business Machine), foi vendido ao Centro Espacial de Houston, a fim de ser utilizado em missões do ônibus espacial Apollo. Ambos os sistemas possuíam a funcionalidade básica de um hipertexto atual, no caso, as conexões por meio de links e a atualização a partir da existência de outros documentos. Por outro lado, diferiam muito na questão da interface, pois se baseavam no texto e a mais simples das operações requeria comandos complexos.

O Aspen Movie Map, em 1978, provavelmente foi o primeiro sistema hipermídia. Construído por Andrew Lippman no grupo de pesquisa Arquitetura das Máquinas residente no Massachussets Institut for Technology e que, posteriormente, auxiliou na formação do Media Lab. Era um programa que permitia ao interlocutor simular uma viagem através da cidade de Aspen em uma tela de computador. O ineditismo deste sistema advém de sua diferenciação em relação ao acesso às informações, já que o interlocutor realiza sua busca através de um rol de informações linkadas umas às outras e não a partir de um comando.

Em 1972, segundo Dias (1999), desenvolveu-se o ZOG $^{15}$. Em 1983, este sistema foi evoluído e denominado KMS ou Knowledge Management System. Era um sistema de hipertextos que se caracterizava a partir de um tipo único de blocos de informação denominado frame. A tela do computador era divida em dois frames, mas era impossível para o interlocutor misturar blocos informativos amplos ou específicos. O KMS foi otimizado a fim de acelerar a velocidade de navegação, de modo que o frame de destino é mostrado instantaneamente de acordo com um click do mouse. Se um item na tela não está conectado a um nó de informação, a ação de clicar sobre um link criará um frame vazio, tornando a navegação do interlocutor interativa e especial. Neste sistema de hipertextos não havia separação entre os interlocutores (autor e leitor), de modo que as alterações elaboradas em um documento eram permanentes, tornando este hipertexto um produto da interatividade entre, primeiramente, o interlocutor e o texto e, conseqüentemente, entre todos interlocutores que compartilhavam e observavam essas alterações.

Com o surgimento do $K M S$, a década de 80 mostrou-se como um período de grandes avanços no âmbito da informática. Inúmeros dispositivos para aumento de armazenamento de

\footnotetext{
${ }^{15}$ ZOG não é uma sigla e, portanto, nada significa. O nome foi escolhido devido à facilidade da pronúncia
} (NIELSEN: 1995). 
informação e o desenvolvimento de interfaces gráficas acessíveis a interlocutores leigos contribuíram para que os computadores aportassem nos ambientes domésticos e no dia-a-dia das pessoas. Ainda de acordo com Dias (1999) e Nielsen (1995), diferentes tipos de hipertexto foram elaborados até hoje, tais como:

- $\mathrm{O}$ Guide é reconhecido como um hipertexto pioneiro no que diz respeito a sistemas comerciais para computadores domésticos. Elaborado tanto para plataformas IBM como para Macintosh por Peter Brown na Universidade de Kent na Inglaterra, o Guide passou a ser vendido pela Office Workstations em 1984. Assim como o Notecards, este sistema hipertextual é baseado na rolagem de textos ao invés de blocos informativos fixos. Desta maneira, os links têm a função de remeter o interlocutor a outras partes deste mesmo hipertexto, de modo que estes elos acessíveis estão associados a marcações, o que os torna passíveis de acesso. Além disso, o Guide abarca três tipos de links: substitutivos, pop-ups e jumpeadores;

- O Symbolics Document Examiner foi elaborado para as estações de trabalho Symbolics e que atuava como uma interface hipertextual para documentação online. O tutorial para o Symbolics também existia em versão impressa e o modo digital de procura informativa relaciona este sistema de hipertextos ao mundo real, pois se trata de uma ferramenta que facilita a busca por materiais documentados;

O TIES (The Interactive Encyclopedia System ou Hyperties) foi desenvolvido na Universidade de Maryland por Ben Shneiderman e que posteriormente foi denominado Hyperties. Foi amplamente utilizado em exposições arqueológicas e fotográficas, pois permitia aos interlocutores o acesso a informações a partir de indicações na superfície do texto. Outra possibilidade era rolar o texto até o final e apertar a tecla ENTER. No entanto, este sistema de hipertextos não permitia, em primeira instância, "saltos" entre janelas, mas ao clicar do mouse, surgia uma janela à parte e mostrava ao interlocutor o conteúdo daquele link. Diante deste elo acessível, o interlocutor é levado para a primeira de um rol de páginas, ao contrário do que ocorre no $K M S$, cujo links apontam para páginas simples; 
- Notecards: Construído pela Xerox Palo Alto Research Center, foi aplicado para materiais técnicos e sua organização, escrita e leitura. Cada bloco informativo ou nó é um notecard que pode ser aberto como uma janela na tela. Os interlocutores podem manter quantos notecards abertos quiserem, mas isso aumenta o risco da descentralização em excesso da informação. Os links eram elaborados entre cards e dispostos a partir de ícones ou de caixas de diálogos que continham o destino de tal card, de modo que "[...] the link type is a label chosen by the user to specify the relation between the departure card and the destination card for the link" (NIELSEN, 1995, p. 49). Nos notecards estão inclusos os browser card, que abrigam o panorama estrutural das relações existentes entre os cards e os links;

- Intermedia: elaborado pelo Institut for Research and Scholarship na Universidade Brown e promovia a interligação entre redes, denominadas webs e seus respectivos links. Tratava-se de uma espécie de um universo informativo amplo organizado a partir de redes de menor alcance. Baseava-se no modelo de rolamento de janelas, como o Guide e o NoteCards. Neste sistema, era possível escrever novas aplicações hipertextuais e integrá-las a frameworks já existentes do Intermedia. Os links eram bidirecionais e, deste modo, não havia diferenças entre links de entrada e de destino;

- Writing Environment ou WE: desenvolvido na Universidade da Califórnia, tinha como finalidade assemelhar-se ao processo cognitivo de escrita de textos e abarcar todos os seus estágios;

- Hypercard: seu mentor, Bill Atkinson, admitiu que este não era um hipertexto em seu início. Este sistema foi um sucesso na década de 80, pois era parte integrante dos computadores Macintosh e, em segunda instância, por incluir um programa denominado Hypertalk, o qual se caracterizava como um software de programação simples e fácil de usar. De acordo com o nome, o Hypercard é baseado na metáfora dos cartões e baseado em sistemas de frames, como o $K M S$, mas que continha nós informativos menores. 
A partir daí, as pesquisas avançaram até o desenvolvimento do CD-ROM, em 1993, quando a Voyager Company lançou o filme A Hard Day's Night, do Beatles. Devido às tecnologias conhecidas na época, não se trata de um filme nos moldes atuais, mas em formato comprimido. Em 1990, Tim Berners-Lee e seus colegas do CERN (the European Center for Nuclear Physics Research), localizado em Geneva, Suíça, desenvolveram a World Wide Web (WWW). O Mosaic tornou-se o programa mais popular para a navegação na rede. Eram os primeiros passos da atual configuração da Internet.

\subsubsection{O que é hipertexto?}

O estudo do hipertexto teve início em tempos nos quais a rede mundial de computadores não se encontrava na condição atual, mais precisamente, na década de 80 e em universidades localizadas nos Estados Unidos. A transformação de uma interligação computadorizada e informativa em um veículo comunicativo com características destoantes do rádio, da televisão e dos meios impressos faz com que o hipertexto adquira importância fundamental na produção e recepção de sentidos. Desta maneira, os autores aqui citados pertencem a diferentes estágios de pesquisa e, conseqüentemente, realizam considerações que se mostram referentes a aspectos divergentes do hipertexto não somente por critérios científicos, mas também devido à rápida evolução dos mecanismos da informática. Daí o estudo do hipertexto não se restringir ao âmbito computacional, mas também a outros campos de pesquisa, como a lingüística e o jornalismo. O aspecto revolucionário da linguagem da Internet faz com que o hipertexto não seja estudado somente a partir de seus aspectos técnicos, mas também do ponto de vista textual-discursivo. Assim, as prioridades desta pesquisa centram-se no que diz respeito às características do hipertexto aplicadas à lingüística textual, ao jornalismo e às suas configurações eletrônicas.

O hipertexto digital, suportado pela rede mundial de computadores, tem diferentes definições. Serão listadas aqui algumas delas, em parte compiladas por Castro (2001). Os estudos dos autores estão restritos às caracterizações do hipertexto e suas possíveis conseqüências no que diz respeito à elaboração e recepção textuais. 
O hipertexto possui formas diferenciadas do texto impresso. Em primeira instância, os componentes no qual os textos impressos fixam-se são relativos a um determinado suporte e este é caracterizado a partir de seus aspectos materiais. Ao contrário dos objetos materiais de leitura, o hipertexto não tem um lugar específico (MONTEIRO: 2000). Desta maneira, há uma alteração nos componentes materiais de leitura e, conseqüentemente, as formas influenciarão na produção do conteúdo, já que a relação entre suporte material e construção de sentidos é mútua e recíproca. Assim, os conceitos forma e conteúdo não podem ser abordados antagonicamente, mas como uma relação retroalimentativa. As atividades humanas geram novas linguagens que, por sua vez, geram novos textos (CHARTIER, cit. por MONTEIRO, 2000, p. 4).

Hipertextos são elaborados a partir de novas formas de tessituras semânticas, já que se trata de um texto recente contextualizado em um ambiente telemático. Hipertexto é, portanto, uma nova maneira de armazenamento informativo e, conseqüentemente, de manuseio destas informações. Diante disso, o fator de interatividade preconiza um alto grau de aproximação entre os interlocutores, já que o interlocutor determina quais nós informativos seguir, trilhando caminhos infinitos (SALMERÓN, CAÑAS, KINTSCH \& FAJARDO: 2005). O hipertexto, portanto, é considerado mais do que uma alternativa aos textos impressos. Isso vai de encontro às principais características de hipertexto, as quais dentre muitas se destacam a descentralização e multimidialidade.

Palacios (1999) afirma que a hipertextualidade ou não-linearidade textual não é um fenômeno computacional, já que a disposição desordenada de informações pode ser encontrada em enciclopédias e dicionários, de modo que qualquer configuração textual nãolinear é exemplo de hipertexto. Assim, o hipertexto não possui linearidade quando da sua forma de armazenamento, ou seja, no seu aspecto técnico. Entretanto, o hipertexto, considerado aqui como qualquer texto que esteja ambientado na rede mundial de computadores, possui particularidades se comparados a hipertextos impressos. Como demonstrado no excerto referente à história do hipertexto, observa-se um extenso período evolutivo entre as tentativas pioneiras de se elaborarem textos em bases que não impressas e os hipertextos modernos baseadas na rede mundial de computadores. Diante disso, o conceito de hipertexto utilizado nessa pesquisa refere-se ao hipertexto atual suportado na rede mundial de computadores é assim visto somente neste contexto. Não obstante, sítios eletrônicos mostram-se complexos em sua estrutura e os links adquirem importância fundamental, pois 
relacionam dois ou mais hipertextos, controlando o fluxo e o acesso informativo disponível na rede. Portanto, o hipertexto deve sua existência ao medium eletrônico denominado computador, já que blocos hipertextuais são interligados por meio de nexos eletrônicos computadorizados (SNYDER: 1998).

No nível textual, a disposição caótica de informações é atualizada e ordenada pelo interlocutor a partir de informações consideradas cruciais para a leitura e, conseqüentemente, compreensão de um hipertexto, aspecto discutido no capítulo dedicado aos estudos da coerência. A partir disso, nota-se a necessidade de se analisar os diferentes níveis de organização técnica e textual de um sítio e, conseqüentemente, de seus componentes, nós e links, visto que o texto suportado eletronicamente é caracterizado tanto através de aspectos técnicos quanto textuais.

Há um novo espaço de produção textual (BOLTER: 1991), no qual o hipertexto localiza-se, já que possibilita ao interlocutor um contato mais dinâmico e interativo com dados. A relação do interlocutor com as informações existentes em um ambiente virtual funda-se, em primeira instância, no aparato técnico que sustenta a existência do hipertexto. Como colocado no capítulo referente à história do hipertexto, a elaboração de softwares aliada à construção de dispositivos que possibilitassem a utilização e a formação de novas tecnologias resultou no surgimento de uma linguagem computacional que, posteriormente, tornou-se tão maleável quanto a linguagem escrita. Assim, há determinados hipertextos que preconizam uma linha de gradação de interatividade entre três instâncias: leitor, autor e hipertexto. Um exemplo de alta interatividade é a Wikipédia, projeto de uma enciclopédia eletrônica criada pelo grupo Google e que permite aos interlocutores discutir, subtrair e adicionar informações. Desta maneira, é exeqüível a um lingüista, por exemplo, criar o verbete "Lingüística Textual" e defini-la de acordo com seu conhecimento. Feito isso, outro pesquisador pode vir a adicionar informações ou, até mesmo, traduzi-las para outro idioma. Outra possibilidade é criar links entre os verbetes, configurando-se, portanto, uma enciclopédia eletrônica interativa com grau de interatividade máximo, na qual a tecnologia é oferecida e compartilhada com o interlocutor, ao passo em que os conteúdos são por ele elaborados.

A problemática da interatividade concerne, primeiramente, à diferenciação entre os termos interação e interatividade. $\mathrm{O}$ conceito de interação principia da mediação 
(VITTADINI, cit. por MIELNICZUK, 2001, p. 3). Logo, diz respeito a ações em comum ocorridas entre dois ou mais sujeitos, a fim de que estes possam entrar em contato, de modo que haja um efeito dominó entre estas ações, isto é, que o conjunto de ações seja o resultado da contribuição de cada um dos sujeitos. Por outro lado, a interatividade ausenta-se do entendimento comum de contato interpessoal, característica atribuída à interação. Assim, a interatividade é um conjunto de dispositivos tecnológicos que possibilita o ato comunicativo e que tem como finalidade, segundo Mielniczuk (2001, 2002), a simulação da comunicação entre as pessoas. Portanto, o conceito de interatividade refere-se a um tipo de interação mediado por aparatos tecnológicos que procuram interligar sujeitos que desejam trocar experiências e conhecimentos apreendidos na vivência cotidiana.

Considerando todos os meios de comunicação modernos, nota-se que há diferentes níveis de interatividade. A partir dessa observação e dos critérios para definição do conceito de interatividade, advém a definição de reatividade, definida como "[...] uma situação em que o poder comunicativo não está divido de forma igualitária tornando a ação de determinados agentes limitada em relação aos outros agentes" (MIELNICZUK, 2001, p. 5). Englobam-se neste conceito de reatividade alguns programas de televisão, como aqueles em que o espectador participa de decisões por telefone ou pela Internet; o rádio, o qual abre um canal de comunicação com seus ouvintes; e, até mesmo, um video game, no qual um jogador manipula personagens virtuais. A partir da observação de que há tipos de interatividade em veículos comunicativos divergentes, esmiuçaram-se os conceitos de interação social, compreendida entre homens, e interação técnica, apreendida a partir das relações entre homens e máquinas.

De acordo com Primo (1998), as atuais tecnologias permitem vislumbrar ações futuras, mas muitas delas ainda são tentativas. Desta maneira, a problemática da interatividade é refém dos aspectos tecnológicos e, portanto, as idéias referentes a uma interatividade plena, mediada por computadores, esbarra na definição de interatividade reativa. Considera-se, portanto, que esta modalidade de interação é ampla quando se apontam as relações mediadas por máquinas, ou seja, fraca e limitada. No entanto, como referido no processo histórico do hipertexto, as tecnologias são alvo de revoluções constantes no mundo da informática e o conceito de interatividade reativa é passível de uma nova análise.

Afirma-se aqui que a interação do interlocutor com relação aos jornais é de característica reativa, assim como o que acontece no jornalismo impresso. Em termos mais 
práticos, é o que se observa nos jornais tradicionais, como o envio de cartas. Atualmente, há tecnologias que possibilitam a construção interativa de textos, como no caso da Wikipédia. Por outro lado, estas novas formas de interação não são do interesse do jornal, pois daria ao interlocutor o poder de contra-argumentação. O que se nota é uma direção contrária às possibilidades oferecidas pela Internet e uma extensão da imagem do jornal impresso sendo constantemente transferida à sua versão online. No entanto, este aspecto do hipertexto noticioso ainda será explorado nesta pesquisa.

Frente a esta discussão, nota-se que o conceito de interatividade evoluiu conjuntamente com os dispositivos tecnológicos. Nos termos atuais, a relação homem-máquina-homem adquire importância não somente no espectro informático, mas também nos meandros textuais, tanto no aspecto produtivo quanto receptivo. Desta forma, as características oriundas da estrutura da Internet, as quais acúmulo de informações e não-linearidade técnica, e concretizadas no hipertexto, e os quesitos advindos das tecnologias atuais, como a manipulação destas informações e a possibilidade de o interlocutor interagir neste mundo virtual, interferem na produção de hipertextos, o que trará resultados inéditos na textualização dos sentidos em ambiente telemático.

O hipertexto, portanto, não deve ser observado somente a partir do aspecto técnico da multidirecionalidade, mas também a partir das instâncias de produção e recepção de suas estruturas e conteúdos. Assim, o texto suportado em ambiente eletrônico é multidirecional e estruturalmente complexo, passível de reorganização discursiva e circunscrito por uma constelação informativa, agrupada de acordo com as intenções do autor. Logo, o hipertexto é uma forma de escrita inédita, já que traz à tona a problemática da não-linearidade. Desta maneira, há diferentes possibilidades de leitura de um hipertexto, mas essas escolhas referemse, a princípio, às múltiplas linearizações oferecidas pelo hipertexto. Daí considerar que o hipertexto advém de uma produção escrita concomitantemente linear e multidirecional, isto é, que deve ser caracterizada a partir de dois planos: o estrutural e o textual (DOUGLAS: 1998). Em termos gerais, o processo de elaboração do hipertexto é alterado devido ao contexto no qual se encontra, no caso, um suporte que preconiza inúmeras facilidades no que concerne à busca por informações e que é assim construído.

Desta maneira, o conceito de hipertexto está baseado, a princípio, em um plano estrutural, ou seja, na não-sincronia informacional em torno de um ou mais tópicos centrais 
(BARRETT: 1989). O hipertexto é caracterizado como uma função comunicativa que objetiva a criação de um novo entendimento ou a busca por uma interrogação já formulada. Logo, os aspectos técnicos do hipertexto contribuem de maneira significativa para a conceituação de que a informação é acessível a todos aqueles que possuam ou tenham acesso à ferramenta denominada computador. É fundamental, portanto, observar que a necessidade de se elencar eixos informativos e que pautem uma procura desenfreada por informações que podem se tornar desencontradas. Assim, observa-se que o caos informativo oferecido pela rede mundial de computadores e formalizado em hipertextos e hipermídias interliga-se às centralizações temáticas que terão a finalidade de orientar o interlocutor em um mar de conhecimentos. Aparentemente, trata-se de uma contraposição entre os planos estrutural e linear, mas é uma complementação entre o oferecimento informativo e uma proposição temática concretizada em hipertextos.

O texto digital advém de uma escrita produzida em meio eletrônico, caracterizada como não-sequencial e não-linear, permitindo ao interlocutor o acesso a outros hipertextos (NELSON: 1992). Este acesso é preconizado a partir das características estruturais do texto suportado em ambiente eletrônico e, conseqüentemente, misturam aspectos estruturais e lineares com configurações multimodais e ramificadas em segmentos complexos. A partir de nós, que são aqui considerados eixos ou blocos informativos, o hipertexto é o abrigo no qual informações de naturezas diversas estão localizadas. Estes nós são representações semióticas transparecidas em imagens, sons, vídeos ou, até mesmo, outros programas de computador. Smith (1994, p. 267) afirma que "[...] o hipertexto, incluindo a hipermídia, é uma tecnologia para definir unidades de informação significativas (nós) e produzir interconexões significativas entre elas".

De acordo com as asserções acima, o hipertexto é, simultaneamente, uma tentativa de ordenação do caos informativo presente na rede mundial de computadores a partir do interesse e da ação dos interlocutores. Os eixos informativos contidos nestes hipertextos e, ao mesmo tempo, as possibilidades de leitura e escolha de caminhos fazem das instâncias de produção e recepção do hipertexto semelhantes e, até mesmo, nulas. O esquema narrativo hipertextual é uma nova forma de ordenação informativa e que contraria a clássica fórmula de início, meio e fim (LANDOW: 1994). Desta forma, a questão da autoria é foco nos estudos de Heim (1993), pois no hipertexto o interlocutor torna-se co-autor do texto, ampliando ainda mais a questão 
da característica dialógica do texto, no qual os interlocutores (re) atualizam significados por meio da leitura.

Segundo Johnson-Eilola (1994), o hipertexto não se caracteriza como livre em sua totalidade. Os interlocutores dependem de uma organização prévia, ou seja, daqueles dados colocados à disposição que serão objeto de visualização, no caso, os nós, ou elos de ativação, os links. O ciberespaço é, para ele, uma rede segmentada e interligada que se mantém viva por meio das informações disponíveis nela. Ainda segundo o autor,

[...] um hipertexto não é hipertextual só porque ele foi escrito num programa computacional específico, mas porque ele segue esta teoria geral da organização textual: os leitores não lêem do começo ao final, ao longo da página, de cima para baixo e de página a pagina. Mas de acordo com uma trilha que eles navegam através de uma rede de nós textuais (JOHSON-EILOLA, 1994, p. 197).

Esta definição vem de encontro aos apontamentos realizados por Nielsen (1995), que definiu o hipertexto por meio do contraste com o texto tradicional. De acordo com o autor, uma seqüência linear que prediz ao texto a ordem na qual o mesmo deve ser lido é característica de um suporte que não possibilita o acesso instantâneo a outras informações, ao contrário de um "[...] texto que se bifurca, que permite que o interlocutor escolha e que se leia melhor numa tela interativa. De acordo com a noção popular, trata-se de uma série de blocos de texto conectados entre si por nexos, que formam diferentes itinerários para o usuário" (LANDOW, 1995, p. 15). Assim, distinguem-se o hipertexto multimídia e o hipertexto baseado na rede mundial de computadores. O primeiro concerne aos programas de computador que, não conectados a Internet, alocam-se em um espaço virtual, porém limitado, o que implica em um sistema que lide com textos lineares ou planos. No entanto, a informação hipertextual não é centralizada e não possui uma estrutura regular, o que acaba por sugerir a existência de nós e links, que possibilitarão a existência de textos simultâneos e instantaneamente atualizados. Com relação ao hipertexto baseado na rede, ele é considerado um instrumento que conserva as características da modalidade multimídia, mas que, integrado, facilita o acesso a informações devido às transformações que ocorreram em sua interface, disponibilizando ao interlocutor gráficos que o seduzem a buscar mais hipertextos.

O acesso instantâneo a outros hipertextos preconiza a existência de um banco de dados a partir de uma série de elementos tecnológicos. O hipertexto é, portanto, um sistema de 
armazenamento e disposição de dados que permite o acesso a informações de maneira nãoseqüencial. Do âmbito tecnológico, é definido como um grupo de elementos técnicos que oferecem ao interlocutor dados configurados de modo que ele escolha o seu caminho. É formado por blocos informativos ou nós que são interligados por links. Uma escrita nãoseqüencial e que possibilita ao interlocutor interatividade e multiplicidade de leitura. De acordo com Kaplan (cit. por KILFEATHER, 1998, p. 17), hipertextos são estruturas múltiplas com domínios textuais. Isso faz com que o autor hipertextual não pressuponha a limitação de seu discurso, tampouco a existência dele, visto que as conexões podem ser vastas a ponto de desconhecer o grau de informação obtida pelo interlocutor.

Assim, o hipertexto é um aparato informativo para a transmissão do conhecimento. Daí ser considerado um meio para produzir, armazenar e transmitir informações, disponibilizado em um suporte acessível por todos aqueles que possuam ou tenham contato com um computador (SANTO \& FREIRE: 2004). Essas informações estão contidas em hipertextos potenciais, colocados nesta pesquisa com eixos informativos, orientadores para a leitura e compreensão de hipertextos. Desta maneira, “ [...] o leitor participa ativamente da redação e edição do documento que lê, podendo traçar caminhos nunca antes imaginados pelo autor, conectando uma infinidade de documentos, criando um novo documento hipertexto a partir dessas associações" (DIAS, cit. por SANTO \& FREIRE, 2004, p. 159).

Fluidez, volatilidade, reconfiguração permanente são as características hipertextuais levantadas por Lévy (1999). Finalmente, segundo Marcuschi (1999), o hipertexto permite o acesso ilimitado a outros hipertextos em tempo real, o que possibilita ao interlocutor a definição interativa do fluxo de leitura, desmembrando uma estrutura tópica definida pelo autor, indeterminando ainda mais esta nova linguagem.

Frente a estas definições, é possível afirmar que o hipertexto é realmente um novo tipo de texto, mas que, paradoxalmente, rompe com alguns fatores de textualidade e potencializa outros. As características elencadas possibilitam a elaboração de uma definição retilínea e, simultaneamente, receptiva com relação a outras novidades tecnológicas.

Contudo, é necessário diferenciar três processos que viabilizam a existência de um hipertexto, de acordo com as pesquisas de Moreira (2003): 
1) Transcrição ou digitalização: processo rudimentar no qual textos impressos são digitalizados e ambientados na rede. Assim, a produção é digital, mas o processo de elaboração não leva em conta o seu suporte, já que é simplesmente copiado do papel. A questão da não-linearidade, característica fundamental do hipertexto, não é obedecida, pois há somente uma conversão de linguagens, ou seja, uma em detrimento da outra;

2) Tradução ou adaptação ou hipertextualização: com a mesma origem da transcrição, o texto impresso é adaptado ao suporte eletrônico, havendo alterações em sua forma e conteúdo. "Neste processo, são considerados dois códigos lingüísticos, a língua natural e a linguagem computacional de marcação de textos (HTML)" (MOREIRA, 2003, p. 4) e

3) Criação ou escrita hipertextual: o que diferencia este processo é a criação de nós e links referenciais, que são elaborados entre partes de um mesmo texto, e links semânticos, que remetem o interlocutor a diferentes hipertextos.

Os conceitos de e-texto, hipertexto e hiperrede levantados por (STORRER: 2002), a fim de discutir a definição sobre hipertexto, vão de encontro aos processos levantados por Moreira (2003). E-texto assemelha-se à transcrição e digitalização, definido como um documento seqüencialmente organizado e disponível na rede mundial de computadores. Desta maneira, etextos são documentos impressos digitalizados. O hipertexto é uma rede de nós interligada por links, possuindo funções textuais tradicionais, além de um tema global. A diferença entre hipertextos e e-textos reside no fato de que os primeiros são estruturados em nós hipertextuais conectados por intermédio de links. Nota-se que a divergência é exclusivamente baseada nas facilidades oferecidas por um sistema hipertextual localizado em um sistema telemático e é isso que difere textos não-lineares impressos, como dicionários e enciclopédias, e hipertextos. Ademais, estes não têm um fechamento absoluto, aspecto presente em hipertextos impressos. Já uma hiperrede relaciona uma série de hipertextos e e-textos por meio de links ou hiperlinks. A World Wide Web (WWW) é considerada uma hiperrede, pois realiza esta tarefa em sítios de menor expressão, que são denominados de redes parciais. 
As divergências entre os conceitos colocados por Storrer (2002) são baseadas nas flexibilidades oferecidas por dispositivos tecnológicos aplicados aos hipertextos em hiperredes. De acordo com Johnson-Eilola (1994), o hipertexto cria um estado de dependência entre a disponibilidade informativa, já que os conteúdos concretizados em blocos informativos e relacionados por meio de links e o interlocutor.

\subsubsection{O nó como característica linear do hipertexto}

As condições de produção do hipertexto (cf. MONTEIRO: 2000), preconizada pela reciprocidade entre forma e conteúdo, depende, especificamente, das configurações presentes na rede mundial de computadores, já que suas características cabais dão-se por meio dos nós e links:

- Nós: é o conteúdo textual que compõe a telemática, representado por qualquer nível sintagmático. "Os nós formam blocos informacionais (fragmentos de informação) que operam como pontos do (sic) ligamento virtual da rede hipertextual" (MARCUSCHI, 2000, p. 10) e

- Links: objetos notados com destaque por meio de alteração de cor ou sublinhamento e que possibilitam ao interlocutor a sua ativação por meio de um click com o mouse. Esta ação remeterá a outros hipertextos. Os links “(...) são a alma do hipertexto e os elementos cruciais para que as peças se interconectem" (MARCUSCHI, 2000, p. 10).

Um dos componentes de um sistema hipertextual abrangente organizado de maneira não-linear e com funções e temas textuais, mas com instâncias ordenativas diferenciadas do texto impresso é a definição de hipertexto segundo Huber (2005). Assim, a grande questão refere-se à organização hipertextual e fundamental é o hipertexto estar ambientado em um programa que possibilite ao interlocutor o acesso a outros hipertextos instantaneamente por meio dos links. Concentrando-se em algumas características do hipertexto, observa-se a existência de determinados aspectos: nós (Knoten), que compreendem a estrutura (Struktur), o 
conteúdo (Inhalt), a extensão (Größe) e as formas de apresentação (Darstellungsform), e links. Estes aspectos são, em sua maioria, comparáveis ou idênticos a um texto tradicional.

Nós são considerados por Huber (2005) todas as características do hipertexto, ou seja, elementos paratextuais que caracterizam materialmente um hipertexto e desempenham a função de orientadores hipertextuais, em conjunto com unidades atômicas de informação, bem como o conteúdo destes hipertextos. Desta maneira, o conceito de nó advém das observações sobre o hipertexto tanto em seu aspecto técnico quanto textual. Assim, a estrutura de um hipertexto, seus limites, bem como suas configurações que preenchem espaços no hipertexto são consideradas representantes de nós. Assim, é possível ao interlocutor navegar entre diferentes nós presentes na rede. São também concretizadores de nós os conteúdos de um hipertexto. De acordo com Bolter (1991), o conteúdo de um nó é revelado por meio de palavras, parágrafos ou gráficos digitalizados. É fundamental observar que os blocos informativos presentes em hipertextos concretizam proposições coerentes. Dessa maneira, “ [...] o princípio da relevância [...] afirma que um nó deve se preenchido somente a partir de expressões centrais oriundas de idéias singulares. No mais, expressões periféricas devem ser elaboradas como idéias próprias e interligadas por links e concretizadas em outros nós" (HUBER, 2005, p. 52). ${ }^{16}$

No que diz respeito à extensão de um hipertexto, a regra geral é que os blocos informativos não devem ultrapassar uma centena de linhas, assim como o número de frases deve ser de, no máximo, sete. Esse cálculo advém de pesquisas psicolingüísticas relacionadas à capacidade da memória de curto prazo em armazenar unidades informativas (chunks) de forma rápida e em curtos períodos.

Concernente aos tipos de nós de um hipertexto, Huber (2005) sugere a seguinte classificação:

- Nós de conteúdo: referem-se aos aspectos semióticos de um hipertexto, já que o o mesmo comporta uma multisemiose;

\footnotetext{
16 „Das ,relevance principle’ von Horn besagt ähnliches, nämlich, dass ein Knoten nur die zentrale Aussage einer einzigen Idee beinhalten darf. Weitere, periphere Aussagen zur selben Idee sollten, durch Links verbunden, in anderen Knoten abgelegt werden" (HUBER, 2005, p. 52).
} 
- Nós funcionais ou de organização: através de nós estruturais e de navegação desempenham funções de orientação aos interlocutores dos hipertextos. No caso de textos impressos, essas características são denominadas paratextos;

- Meta-nós: é passível de observação em hipertextos que abrigam nós compreensíveis somente a partir de outros hipertextos. Não se completam por si só e dependem de links para que sejam entendidos não somente como nós estruturais, mas que também revelam um conteúdo a ser lido. Meta-nós são também denominados textos de alargamento (Stretchtext).

\subsubsection{Características do hipertexto}

Elaboradas estas definições, o hipertexto ainda necessita de uma análise mais profunda e que abarque com mais abrangência a sua existência. Para isso, foram consultados Lévy (1993), que estudou mais intensamente o fenômeno telemático, e Marcuschi (2000) que se concentrou nas divergências lingüísticas trazidas pelo hipertexto.

Segundo Lévy (1993), esta nova tipologia textual expande os fatores de textualidade para:

1) Metamorfose: é o regimento de velocidade predominante na sociedade pósmoderna. Daí o fator de volatilidade e instabilidade das formas textuais conhecidas, fator que também se aplica aos textos produzidos eletronicamente;

2) Heterogeneidade: é o grande número de ligações e que podem ampliar infinitamente o hipertexto observado no momento, expandindo os temas e seus derivados de acordo com o número de links disponíveis. Entretanto, “[...] os nós e conexões de uma rede hipertextual são heterogêneos. Na memória serão encontradas imagens, sons, palavras, diversas sensações, modelos etc., e as conexões serão lógicas, afetivas" (LÉVY, 1993, p. 25); 
3) Multiplicidade e coerência permanentes: com uma estrutura frágil, informações hipertextuais podem ter continuidade de sentidos, já que se encontram interconectadas;

4) Exterioridade ou descentração: elementos relevantes ou de centração semântica inexistem no hipertexto, pois as fronteiras são permanentemente extravasadas e a incorporação de novas informações caracterizam o hipertexto como inacabado;

5) Efemeridade dos centros: volatilidade, instabilidade e constante rotação de nós caracterizam o hipertexto através de rizomas que desenham mapas como num conflito geopolítico, ou seja, na iminência de se alterarem essencialmente;

6) Acessibilidade ou topologia: é a proximidade (corroborada, de certa maneira, pela quantidade de informações) que o interlocutor possui com as possíveis (re) significações oferecidas pela telemática, que também dita uma ordem, pois tudo que está imerso na rede faz uso dela para existir. O pesquisador caracteriza a rede mundial como seu próprio espaço, ou seja, ela desenha as suas condições, aspecto notado diferencialmente no mundo real, no qual a rede está localizada em um espaço.

Como visto, o pesquisador concentra-se nos aspectos técnicos definidos da rede mundial de computadores. A configuração hipertexto, alvo das seis asserções acima, também contribui de maneira significativa para os estudos lingüísticos a serem empregados com tal corpus, já que se tratam de uma manifestação lingüística diferenciada. A característica de alternância constante não é um fenômeno recente, já que, segundo Bakhtin (2000), toda manifestação textual surge de uma atividade humana. Assim como o hipertexto adveio de uma nova maneira de organizar dados cruzados, outras tipologias textuais surgiram a partir deste fenômeno, como os gêneros de conversas instantâneas e o correio eletrônico. É um acontecimento que vem se repetindo freqüentemente, já que constantes alterações na forma e conteúdo das manifestações textuais acompanham o ritmo de desenvolvimento tecnológico. No entanto, estes gêneros recentes encontram-se em um meio que os faz heterogêneos, dado que não basta somente a interação homem e máquina contribuindo para este processo, mas também o caráter telemático do hipertexto. Este, por sua vez, intensifica o processo interativo 
e dialógico entre os interlocutores, o que faz do texto em meio eletrônico um todo se constituindo permanentemente.

Daí advém a fragilidade e o movimento histórico-momentâneo deste novo gênero textual, já que a sua transformação encontra formas rápidas de concretização e incorporação social, dada a velocidade na qual é elaborado e recepcionado. No entanto, apesar de fractal, o hipertexto é passível de uma construção temática ou tópica, pois centra, textualmente, elementos semanticamente relevantes e, para isso, faz uso de nós e links, que são os eixos de conexão formulados interpretativamente pelo autor do texto. Trata-se de uma espécie de concretização de imagens mentais relativas aos co-autores e que dirigem o interlocutor a determinado assunto, apesar de, muitas vezes, tal caminho ser imprevisível.

Com exceção dos nós e links, a rede, assim como as outras formas textuais existentes, não possui um princípio interno de existência, algo mutável que a possibilite a vida. A sua configuração é dada por agentes externos e, na medida em que estes adicionam ou excluem informações, criam ou desvirtuam possíveis caminhos, a característica da centração instável marca ainda mais o hipertexto. Esta influência externa impossibilita o absolutismo de um ou mais elementos que perfazem determinados temas ou assuntos em um texto. Neste caso, a gama de caminhos a serem percorridos e, além disso, a possibilidade de os mesmos estarem virtualmente presentes e acessíveis no momento da interação faz com que o conhecimento de mundo dos interlocutores seja ainda mais atualizado, fazendo que com que um mapa interativo e complexo exista, sem dominância, mas sim, com um início. Daí o conceito de topologia elencado por Lévy (1993), formado pela proximidade de dados existentes.

Segundo Marcuschi (1999, p. 3-4) e Koch (s/d, p. 2-3), o hipertexto tem nove características, apresentadas de um ponto de vista mais lingüístico e menos abrangente:

1) Não-linearidade ou Eixo hipertextual: em contraposição ao formato clássico de texto, o digital não possui uma prescrição com relação à ordem de leitura;

2) Volatilidade ou Instabilidade ou Virtualidade: é o caráter passageiro do hipertexto, visto que a virtualidade é o espaço no qual está localizado. Paradoxalmente, a possível solução para o excesso de informações acaba criando a efemeridade das mesmas, ou seja, não se transformam em conhecimento; 
3) Topografia ou Rompimento ou Infinito: devido à ausência hierárquica, o hipertexto acaba por alterar significativamente frames ou qualquer outro modelo de compreensão textual, pois, além de destituir a ordem tradicional do texto, rompe com os limites, dado o número infinito de conexões possíveis;

4) Fragmentário ou Parcial: uma vez que rompe com os limites físicos e textuais, o hipertexto adquire mais parcialidade e menos integridade, tornando-o, portanto, mais, no que diz respeito à sua integridade, superficial. No entanto, esta brevidade acaba destituída no momento em que os links auxiliam na elaboração textual. Segundo Castro (2001: 28), “[...] partes de um todo propõem incontáveis segmentos que possibilitam retornos ou fugas. Por isso, falta ao hipertexto um centro regulador, já que o autor não possui mais controle do tópico e do leitor";

5) Ilimitabilidade: semelhante ao item três, o texto digital não tem restrições físicas e conhecidas no mundo real. Em suporte eletrônico, características contrárias predominam e possibilitam ao interlocutor acesso a qualquer tipo de informação;

6) Multisemiose ou Hipermídia: é a capacidade de interação entre diferentes linguagens em um mesmo espaço. É uma característica observada no mundo real, mas que é potencializada na telemática;

7) Interatividade: paradoxalmente, é o caráter simulado de simultaneidade possível na rede, já que é possível assistir a eventos em tempo real e estar em diversos lugares ao mesmo tempo. É a simulação de interações faciais que caracterizam um diálogo, mas que não passam de simulações, já que se trata de um mundo virtual;

8) Polifonia e intertextualidade: diversas vozes e inúmeros hipertextos passíveis de reorganização instantânea; 
9) Descentração: existência concomitante de informações, o que, conseqüentemente, faz da rede uma série de universos paralelos.

De acordo com a classificação do pesquisador, é possível observar, diferentemente dos estudos de Lévy (1993), que o hipertexto não contradiz tal denominação, pois potencializa muitos aspectos do texto tradicional, uma vez que se encontra em um novo ambiente, o que afeta as condições de produção e recepção, mas não necessariamente, altera significativamente tais etapas.

Dentre as sete características, a não-linearidade é, definitivamente, um aspecto relevante nos estudos hipertextuais. A denominação Eixo hipertextual esclarece algumas divergências com relação a nós e links. Um eixo é algo retilíneo que atua como uma base de sustentação para outros componentes que, por sua vez, terão a função de executar outras tarefas. De acordo com esta nomenclatura, o hipertexto, é, paradigmaticamente, um eixo textual, mas que proporciona a existência de eixos paralelos e que também auxiliarão no caráter diversificado da rede, incluindo aí, textos não-verbais. Assim, a natureza do hipertexto é o próprio texto, mas que conta com infinitos paratextos, representados pelos links, que alteram, essencialmente, os processos de elaboração e recepção textuais, o que acaba por interferir e criar um aspecto de efemeridade, pois tudo é virtual e impossível de contato físico. Esta virtualidade enfatiza ainda mais tal questão, uma vez que o papel das informações acessíveis traz ao hipertexto pontos cada vez menos integrais e mais fragmentados. Ao invés de uma leitura linear, o hipertexto secciona a integridade de um texto clássico em blocos que podem ou não ser acessados. Difere, portanto, de uma leitura que procura abarcar a integridade de um determinado tema.

Ainda segundo Marcuschi (1999), o aspecto de não-linearidade do hipertexto pode ser observada de acordo com três pontos de vista:

1) A organização dos níveis lingüísticos;

2) O modo de demonstração das informações presentes na rede telemática e suas diversas linguagens, tanto verbais como não-verbais e

3) A disponibilidade de acesso a essas informações. 


\subsection{5 $\mathrm{O}$ interlocutor virtual}

O interlocutor tem inúmeras maneiras de ordenar a leitura de um hipertexto, alterando suas maneiras de compreensão e recepção textuais, ao passo em que limites são constantemente rompidos. Aos modelos formados a partir do contato com textos tradicionais, outros se somarão ao seu conhecimento de mundo, o que amplia a relação com uma nova abrangência de gêneros textuais, o que não significa que esta nova relação possibilite a ele maior ou menor capacidade interpretativa. É uma problemática que se dirige ao contraponto colocado acima, já que o hipertexto potencializa características cabais do texto tradicional. Logo, o termo hiper pode ser estendido a todos as atividades correntes da leitura de um hipertexto, dado que ele não somente potencializa aspectos clássicos do texto, mas os altera.

A partir disso, o conceito de interlocutor torna-se ainda mais definido, já que ambos têm a possibilidade de apresentar o texto ainda mais dialógico, ou seja, interativo. Ao formular imagens mentais de um interlocutor, o autor sofre uma influência direta decorrida desta imagem e tal é demonstrada na elaboração do texto. No aspecto hipertextual, esta alteração mostra-se na disposição dos links, pois o autor procura satisfazer a necessidade informativa do interlocutor e pressupõe que eles serão acessados; por outro lado, o interlocutor tem a possibilidade de construir ou desconstruir mais facilmente determinado discurso, uma vez que o hipertexto não tem um, mas vários elementos semanticamente relevantes e que levam a outros hipertextos. Portanto, o interlocutor não é um flâneur, com um “[...] caminhar que não é intencional, nem condicionado a seguir caminhos pré-estabelecidos, mas que marca simbolicamente o 'seu' espaço, à medida que escreve percursos além da macro-estrutura textual" (CASTRO, 2001, p. 30). Há, sim, uma estrutura não-linear, mas os elementos seguidos pelo interlocutor têm a possibilidade de se enquadrarem em centros rotativos que têm semelhanças entre seus elementos. Logo, há uma ordem discursiva hipertextual, aspecto crucial para o estudo da coerência em hipertextos.

No quesito de liberdade de escolhas de caminhos a serem seguidos, o interlocutor é conduzido por trilhas disponíveis para acesso e estas são disponibilizadas pelo autor; a idéia de autonomia é partilhada entre os interlocutores, já que ambos têm o papel digladiador de constante atualização de significados dentro de um texto: 
Mesmo quando um autor escolhe um conjunto de representações para determinado conceito, isto é, quando estabelece os possíveis links de seu texto, o faz por meio de critérios subjetivos de escolha, o faz em função de um contexto partilhado com um conjunto imaginário de leitores. A liberdade de escolha do leitor é, portanto, a possível, não a ideal [...] (XAVIER, cit. por MOREIRA, 2003, p. 4).

A não ser como expressão do autor que o cria, o texto não existe, melhor dizendo, não preexiste ao leitor, vez que este é quem lhe atribui significados, ancorado em seu repertório de conhecimentos, nos textos que compõem sua estrutura cognitiva. O leitor, nesse processo, é tão vital quanto o autor (EAGLETON, cit. por XAVIER, 2003, p. 5). Assim, a possibilidade de caminhos a serem percorridos depende exclusivamente da oferta dos mesmos; sem ela, o hipertexto não seria caracterizado como tal. A estrutura macrotextual é diversificada de acordo com outras estruturas possibilitadas por outros interlocutores. O aspecto de interatividade extrema procura definir tal problemática; entretanto, não é possível discernir acerca da dialogização textual sem a presença de duas entidades com diferentes conhecimentos de mundo e que interferirão divergentemente no processo de elaboraçãorecepção textual. Ele seria anulado. Apesar de a não-linearidade presente em enciclopédias, por exemplo, ter funcionado como um suporte real para a idealização de máquinas aptas a solucionar o problema da procura pela informação, o hipertexto tem em seus rizomas e ramificações a ausência de linearidade. A existência de tal aspecto não depende da vontade do interlocutor, já que é um fator hipertextual, diferentemente do que ocorre no simples salto de capítulos, não inerente ao gênero textual.

Os usos lingüísticos presentes no hipertexto remetem aos estudos de Xavier (2001), já que o pesquisador viu-se diante da necessidade de pesquisas com relação ao papel do link no hipertexto, ou como ele mesmo denomina, hiperlink.

\subsection{Considerações acerca do link}

Para se analisar o papel do link no hipertexto, serão retomadas e ampliadas as definições de texto concernentes ao embasamento teórico da pesquisa. Isso é necessário, pois se 
considera o hipertexto não somente a partir de seu aparato técnico, mas também textual. Desta feita, definições de texto a partir de considerações sóciocognitivas com relação à língua e ao texto procuram alçar o aspecto da coerência no hipertexto a partir de uma estrutura fractal suportada em uma rede informativa baseada em uma estrutura rizomática de informações.

\subsubsection{O link como fator de coerência}

O texto é um objeto lingüístico multifacetado e formado por componentes estruturais, semânticos e cognitivos, além da influência dos fatores de contexto. Estendendo-se estes apontamentos, alega-se que o texto

[...] é um jogo pleno de atividades verbais, heterogêneas, interacionais, cognitivas, sociais e históricas interdependentes e inter-relacionadas (de BEAUGRANDE, cit. por XAVIER, 2001, p. 166). Ela é resultado de ações lingüísticas, sociais e cognitivas dos sujeitos que as realizam no interior de eventos reais, i.e., envoltos em acontecimentos discursivos situados na história. Ela é compreendida como um processo repleto de ações verbais integradas produzidas por agentes sociais historicamente constituídos. Estes agentes, dotados de volição própria inferem, pressupõem e geram sentidos on-line a partir das pistas lingüísticas de acordo com o contexto de sua produção. Nestas ações verbais estão envolvidas operações cognitivas, cujas decisões interpretativas (avaliações, retomadas e conclusões) dos sujeitos são negociadas momento a momento e modelas conforme o desenrolar da interação social que lhe deu origem (XAVIER, 2001, p. 166).

De acordo com os pressupostos acima, o conceito de língua pode ser tomado como um espaço no qual interlocutores necessitam de realizações verbais que se originem a partir de choques entre conhecimentos de mundo, ou seja, a partir do momento em que dois sujeitos histórico-socialmente determinados dialogam, há negociação de sentidos, se considerados como fruto de interação textual. A partir disso, o autor coloca sua concepção de texto:

Textos são concebidos como 'formas de cognição social. São muito mais que 'roupagens do pensamento' (como advogam alguns cognitivistas). O texto é, antes de tudo, constitutivo do próprio saber, é o próprio conhecimento em si, haja vista que todo conhecimento declarativo circulante em uma dada sociedade é um conhecimento lingüístico e social alicerçado em certos modos e gêneros textuais (ANTOS, cit. por XAVIER, 2001, p. 166). Os textos são a essência do conhecimento, matéria prima do saber e não só recursos técnicos que viabilizam a exposição de saberes outros in abstracto que ganham visibilidade e concretude, quando textualizados. Além de permitir tecnicamente a simultaneidade entre a escrita e a ciência, os textos são elemento-base desta mesma ciência, que deles se utiliza tanto como suporte para sistematização, 
organização e conservação do novo saber descoberto, quanto como componente gerador de outros saberes científicos. Ou seja, eles são tão essenciais para a produção do conhecimento quanto para a sua projeção e divulgação no mundo (XAVIER, 2001, p. 166).

O texto concretiza o conhecimento e, ao mesmo tempo, é também a maneira pela qual sujeitos apoderam-se de mundos cognitivamente ordenados e explicam aos mesmos como estes mundos funcionam. É a textualização dos conflitos do mundo por meio de interatividades sociolingüísticas. É a partir desta concepção como organizador do conhecimento e do mundo que o autor considera o hipertexto como o aproximador virtual entre as interações verbais, isto é, um veículo cognitivo que leva o conhecimento de maneira mais rápida e precisa aos interlocutores.

Os interlocutores da rede mundial têm, à sua disposição, uma infinidade de informações a serem exploradas que, com um simples click do mouse, podem ser instantaneamente acessadas. Estas trilhas seguidas pelo interlocutor tornam-se, em uma perspectiva lingüística, escopos referenciais, já que incorporam um todo oriundo de um trabalho cognitivo moldado em gêneros textuais (BAKHTIN: 2002). Assim, os elementos de um texto são considerados referentes interdependentes que contribuem para sua macroestruturação (van DIJK: 2002).

De acordo com os apontamentos de Koch (2004: 59-60),

[...] sendo a referenciação um caso geral de operação dos elementos designadores, todos os casos de progressão referencial são baseados em algum tipo de referenciação, não importando se são os mesmos elementos que recorrem ou não. Referir é, portanto, uma atividade de designação realizável por meio da língua sem implicar uma relação especular língua-mundo.

Koch (2004) elencou três estratégias de referenciação, encarando-a como um fenômeno cognitivo-textual que não somente preconiza a progressão textual, mas também a permanente recategorização de referentes que se alocam em outras proposições. Assim:

1. Construção/ ativação: inserção de um objeto novo no âmbito textual-discursivo. A partir disso, o mesmo passa a ter relevância tópica; 
2. Reconstrução/ reativação: trata-se da referenciação a um objeto, de modo a reintroduzí-lo no espaço textual;

3. Desfocalização/ desativação: é a alteração focal entre objetos do discurso, na qual um sai e outro referente passa a ocupar a posição tópica do texto.

A referência extratextual diferencia-se da classificação desta referenciação elencada pela lingüística textual, já que esta analisa os referentes anafóricos e catafóricos textuais, recorrentes no mesmo texto e não fora dele. O ineditismo do hipertexto com relação à referenciação é a sua possibilidade de o mesmo elemento ser uma conexão que rompe com os limites do nó informativo, mas não de uma coerência hipertextual. Assim, há extravasamento estrutural, mas não textual. No entanto, esta referenciação implica, como busca pela (re)organização do texto, a progressão tópica, já que outros referentes são incorporados ao hipertexto inicial.

Daí, é necessário distinguir duas modalidades do fenômeno no âmbito do hipertexto: referência digital co-hipertextual e pan-hipertextual (XAVIER: 2001):

1) Referenciação digital co-hipertextual ou hipertexto fechado: de acordo com a denominação, refere-se aos processos textuais contínuos em estruturas fechadas e autocontidas. “[...] os links e nós são monitorados, na medida em que o leque de informações é esgotável" (CASTRO, 2001, p. 38). Dá-se por meio de links que conectam hipertextos de um mesmo sítio. É muito comum em grandes portais, como Universo On-line (UOL), Internet Grátis (IG) e sites jornalísticos.

2) Referenciação digital pan-hipertextual ou hipertexto aberto: assim como na referenciação digital co-hipertextual, trata-se da busca pela organização textual externa à página eletrônica na qual se iniciou a leitura do hipertexto. As possibilidades de (des)construção de discursos são maiores neste tipo de referenciação, já que um mesmo website é limitado no que diz respeito a informações de diferentes procedências. 
3) Referenciação digital co- e pan-hipertextual ou hipertexto fechado e aberto: caracteriza-se por meio de links que remetem a sítios da mesma estrutura e também fora dela.

Portanto, considera-se o link como um elemento referencial dentro do hipertexto. Logo, confere-se a ele o papel de relacionar nós e links de maneira a se observar uma estrutura suportada em uma rede informativa não-linear, mas que, se analisada a partir de determinados sítios, revela-se como um texto coerente, porém fragmentado.

É proposto por XAVIER (2001) propõe um estudo baseado em dois questionamentos condizentes com as indagações propostas por esta pesquisa:

1) Quais os aspectos técnicos dos links?;

2) Quais os aspectos textuais dos links? e

3) Que papel desempenha o link no âmbito da coerência, especificamente no da referenciação, no momento da leitura hipertextual?

\subsubsection{O que são links?}

Desta feita, serão tecidas considerações a respeito do hipertexto e dos links a partir da perspectiva da lingüística textual e, especificamente, adotando-se a relação entre nós e links como interdependências semânticas circunscritas por um todo coerente e que abarque a estrutura de um hipertexto.

De acordo com Marcuschi (2000: 10), links são

[...] ligações constituídas por itens lexicais, sintagmas, ícones ou elementos ressaltados num texto que servem para fazer uma conexão ou estabelecer os nexos. Na realidade, os interconectores são a alma do hipertexto e os elementos cruciais para que as peças se interconectem. 
A questão da acessibilidade levantada pelo papel das conexões hipertextuais refere-se ao ato de clicar com o mouse. Entretanto, de um hipertexto passa-se a outro quase que instantaneamente e, a partir disso, observam-se outros elementos que se originaram a partir de uma indicação acessível e hipertextual. Desta maneira, os "[...] itens lexicais, sintagmas, ícones ou elementos [...]" citados por Marcuschi passam a ser vistos como referentes textuais que operam uma continuidade de sentidos, bem como tais peças também citadas pelo autor.

Retomando Nelson (1992), o hipertexto pode ser descrito de acordo com as instâncias elaborativas e receptivas:

1) Caracteriza-se por meio de um eixo hipertextual dotado de inúmeras informações, possibilitando a sua edição em um mundo virtual e

2) Um sistema de organização de dados, no qual os mesmos podem ser reorganizados de acordo com um modo de pensar diferenciado.

O fator interatividade propõe aos interlocutores um esforço configurativo concernente à disposição dos links, o que leva à acessibilidade de informações e, consequentemente, à formação de uma teia semântico-textual. Portanto, o trabalho de produção hipertextual leva em conta as pressuposições concretizadas na formatação coerente de um sítio. Assim, ao elaborar um hipertexto, o produtor

1) Vê-se diante de um amontoado de informações que necessitam, primeiramente, de uma linha interpretativa. Os referentes do hipertexto funcionarão como suporte para que os links sejam construídos, de modo a formar um todo coerente e,

2) Feito isso, o link adquire um papel argumentativo, isto é, procura-se preencher todos os escopos sugeridos pelos referentes hipertextuais.

Conseqüentemente, este eixo altamente informatizado preconiza não somente o acesso a infinitas informações, mas também que a reorganização das mesmas é diferenciada; daí a sugestão hipertextual de uma nova maneira de pensar (LÉVY: 1999). Assim, é uma tecnologia material e também intelectual. São informações que podem ser alteradas de acordo 
com o desejo dos interlocutores, quaisquer que sejam os motivos para agrupamentos diferenciados: crenças, valores, ideologias. "Em outras palavras, o leitor do hipertexto não tem compromisso com uma seqüenciação a priori rígida e inviolável durante a sua leituranavegação" (XAVIER, cit. por XAVIER, 2001, p. 167). É crucial não distinguir o mesmo dispositivo, no caso o link, e duas conseqüências divergentes: a sua materialidade enquanto elo acessível, caracterizando o hipertexto como não-linear, e sua textualidade enquanto elemento textual (MIELNICZUK \& PALACIOS: 2001), no qual o hipertexto e seus respectivos links representam uma linha contínua de elementos semanticamente relevantes, com o objetivo de tornar uma página eletrônica coerente em seu aspecto textual.

Ainda segundo o pesquisador,

[...] a descontinuidade é uma forma de montagem pela qual o dizer acha a sua coesão. $\mathrm{O}$ discurso na superfície digital fortalece-se não devido à linearidade de um desenvolvimento temático qualquer, mas por causa da rede subterrânea de filamentos ditos, não-ditos e ecoados, ainda que à distância, entre os temas afins vinculados entre si por fortes ou tênues relações intertextuais. O hipertexto, então, convida o leitor a re-organizar esta estrutura originalmente descontínua, a bel-prazer, e ele assim o faz em seu 'surfe' virtual, em suas idas-e-vindas a certos hiperlinks, nós ou sítios durante a leitura-navegação” (XAVIER, 2001, p. 167).

A característica essencial do hipertexto é a não-linearidade técnico-material sendo oferecida ao interlocutor para que este a reconstrua de uma maneira lingüisticamente organizada, dispondo uma gama de informações lineares como um texto tradicional, pronto para dar início ao um novo processo de constante mutação. Portanto, o hipertexto é fractal por excelência; entretanto, o processo de elaboração e recepção do mesmo não pode ser considerado como tal, já que ele é decifrado se, e somente se, fragmentado. Daí, retoma-se o princípio da mobilidade dos centros (LÉVY: 1999), ou seja, o hipertexto é desenhado de acordo com a oferta de significados a serem construídos de maneira exploratória por meio dos links.

Tais considerações também envolvem o aspecto sintático-semântico dos links. Partindose do pressuposto de que as estruturas de um hipertexto envolvem nós e links, nota-se que um continuum semântico entre estas partes é plausível desde que um todo seja passível de análise, como colocado por Xavier (2001). No entanto, a integridade e a multifacetação de um hipertexto assemelha-se a um texto tradicional e linear permanente e paralelamente elaborado 
a partir de referências e notas de rodapé. No âmbito dos estudos jornalísticos, a existência de quadros explicativos e textos noticiosos à parte da notícia principal tornam a produção de textos uma atividade que prime menos pela uniformidade de sentidos e mais pela exploração daqueles elementos que desempenham papel relevante na recepção textual.

A descentralização como característica dos hipertextos deve-se, primeiramente, ao suporte no qual está localizado, e, em segunda instância, a partir dos links. Assim, a construção de sentidos neste tipo de texto desafia as pesquisas empreendidas no campo da coerência textual, já que a uniformidade semântico-textual a partir de determinados referentes não se encontra somente em nível linear, mas também em configurações múltiplas que atribuem ao hipertexto um caráter universal e, ao mesmo tempo, circunscrito por indicadores intertextuais.

O estudo da construção de sentidos no hipertexto, sugerindo-se, portanto, uma coerência hipertextual, parte de definições de coerência oriundas de textos lineares. Entretanto, sua aplicabilidade é observada se se considerar os links como operadores de sentidos em hipertextos, os quais tendo a descentralização como característica. Desta forma, é uma tentativa de se analisar o hipertexto a partir de uma ordem semântico-textual que elenca uma hierarquia de referentes, um dos pilares para o estabelecimento da coerência textual. Esta ordem de referentes dá-se no hipertexto a partir de determinados elementos presentes em nós informativos e que serão aproveitados em um elo acessível, a fim de estabelecer uma uniformidade de sentidos e, consequentemente, uma constelação informativa passível de ordenação pelo interlocutor.

Considerando-se que a uniformidade de sentidos no hipertexto dá-se entre nós e links, indaga-se o papel dos links no que diz respeito às funções não somente coesivas, mas também relacionadas à coerência. As diferenciações entre coesão e coerência encontram-se cada vez mais tênues, dado que as relações entre os elementos sintático-semânticos estão sob o crivo de uma unidade textual.

Desta forma, a consideração de que as relações de sentido dão-se entre o texto e suas características hiper, ou seja, a possibilidade de acesso instantâneo a outros hipertextos promovido por links, aventa a hipótese de que os mesmos comportam-se como operadores dêiticos (XAVIER: 2000). O conceito advém do âmbito de estudos da pragmática e diz 
respeito a direcionamentos textuais que apontam o interlocutor para objetos atualizáveis na realidade ou, neste caso, na virtualidade. Desta forma, a primeira função do link seria a dêitica (XAVIER: 2000), ou seja, de apontadores textuais que direcionam o interlocutor a elementos do texto que, por quaisquer motivos, são relevantes para a leitura e compreensão.

A tecnologia hipertextual tem feito amplo uso de links dêitico-textuais. Sítios de grandes corporações, como os analisados nesta pesquisa, baseiam-se em estratégias retóricodiscursivas (CASTRO: 2001), fazendo uso de aspectos multimidiáticos na construção dos links. Atualmente, observam-se links que percorrem toda a página ou que se mostram como construções semioticamente complexas, travestidos em figuras de diferentes características. Assim, é fundamental analisar como essa função de atualização instantânea é criticada a partir dos significados construídos no texto. Com o aprimoramento da construção de páginas eletrônicas, é possível distinguir dois tipos de links, de acordo com Xavier (2000):

1) Links-fixos: são links ativáveis que, como a denominação sugere, são estáveis no sítio e caracterizam a página eletrônica, e

2) Links-móveis: não têm lugar fixo e circulam pela página eletrônica. Atualmente, os sítios disponibilizam os dois tipos, sendo que este, na maioria das vezes, representa um link que direciona o interlocutor para outra página eletrônica.

Apesar de os links encontrarem-se à parte do hipertexto, eles estão inseridos na estrutura hipertextual. Não se trata de um conceito inédito com relação à estrutura, já que há exemplos que demonstram uma leitura não-linear, como dicionários e enciclopédias. No entanto, a adjacência de links ao hipertexto e o seu acesso instantâneo é uma nova forma de arranjo textual. No âmbito estrutural, esta adjacência reflete a existência de textos de extensão menor, mas que elegem um elemento textual considerado indispensável para fins de compreensão, contextualização e intertextualidade ${ }^{17}$. Logo, o hipertexto é uma estrutura complexa que sugere ao interlocutor uma circunscrição de outros textos com maior ou menor extensão. $\mathrm{O}$ nó, que é a representação da unidade de informação, é permeado por outros textos, fazendo-se múltiplo em sua estrutura e caracterizando-se como um texto linear e ambientado e suportado

\footnotetext{
${ }^{17}$ Considera-se uma forma de construção do link, visto que o objetivo desta pesquisa é analisar se ele contribui para a continuidade de sentidos no hipertexto. Diferentes formas de link podem ser encontradas em CASTRO, 2001.
} 
por uma rede estrutural de informações, mas rizomática e sem uma ordem pré-definida. A estrutura do hipertexto é, em primeira instância, um diferencial no que diz respeito à construção e recepção do hipertexto, já que promove uma interlocução não-linear. Entretanto, retorna-se à problemática de o hipertexto ser analisado a partir de dois vieses: o primeiro estrutural, no qual esta afirmação é plausível; já do ponto de vista discursivo, o link pode ser visto como um operador de continuidade de sentidos, como se os hipertextos acessados fossem integrados ao hipertexto de origem. Enquanto dispositivo de construção técnica, o link é a subsistência do hipertexto, pois permite que todas as informações estejam conectadas entre si. Não obstante, o link conecta todas aquelas figuras presentes no mundo real, como instituições e pessoas, possibilitando a elas qualquer tipo de ação que desejarem na virtualidade. A construção de sentidos dá-se, neste novo suporte, por meio de clicks de mouse.

A construção dos links que intermediarão a passagem entre os hipertextos é fundamental, já que entornam um texto a fim de atribuir-lhe ressignificações coerentes, mesmo que desarranjadas. Logo, a construção do hipertexto é uma atividade textual, ocorrida a partir do momento de interatividade do interlocutor com o hipertexto, criando "[...] intersubjetividades negociadas publicamente no mundo" (MONDADA \& DUBOIS, cit. por XAVIER, 2001, p. 168), mas que, neste caso, são empreendidas no mundo virtual.

Estas intersubjetividades desencadeadas a partir do hipertexto, além de conferir aspectos cognitivos a ele, estão em dependência da construção da coerência no hipertexto. A elaboração de links que estejam em dissonância com os sentidos apreendidos em um determinado sítio fere a necessidade comunicativa dos interlocutores e, consequentemente, da própria língua. A construção de um hipertexto passível de leitura e compreensão é imprescindível de um todo coerente formado entre nós e links. Os links, desta forma, funcionam como instâncias conectivas que integram hipertextos de modo a ordená-los de acordo com uma estrutura fragmentada, porém íntegra textualmente.

Entretanto, esta integração promovida pelos links é construída de modo a atribuir relevância a determinados elementos de um texto em consonância com o hipertexto linkado. Esta relevância é elaborada a partir de construções semântico-textuais condicionadas ao conhecimento do interlocutor e a sua necessidade de procura por mais informações. Em grandes portais, como os sítios dos jornais, o editor dos sítios eletrônicos noticiosos procura embasar uma notícia com links que procuram satisfazer o público-leitor. A partir do nó 
informativo, o link é elaborado acerca de um referente que abranja um outro fato tanto ou mais relevante que aquele que gerou o elo acessível. Desta maneira, o jornal procura dar conta daquilo que o seu interlocutor necessita no que diz respeito à construção de um mundo verídico e relevante, apontando a ele o que é importante para o seu cotidiano e para a formação de uma ideologia opinativa. Assim, atribui-se mais uma qualidade ao link, que é sua identificação cognitiva, asseverando que ele é um encapsulador de cargas de sentido (KOCH: 2004), persuadindo o interlocutor a clicar sobre eles. É uma pressuposição decorrida nos modelos cognitivos do autor e que visa alçar todas as associações do interlocutor no momento da interpretação hipertextual, concretizando-as em links.

Em primeira instância, o link sugere aos interlocutores acessos que orientem e facilitem a leitura de um hipertexto. O sítio ou o texto digital vai se construindo e se recuperando de sua fragilidade de acordo com o acesso aos seus respectivos links. Assim, todo link é um elemento de coerência, que dirige o interlocutor a um hipertexto fora daquele hipertexto original, já que “[...] a escolha dos itens lexicais e sintagmas para a constituição do link, bem como o seu posicionamento, é uma das ações vitais no suporte e valor que o autor quer manifestar no hipertexto" (BURBULES, cit. por CASTRO, 2001, p. 62).

Os links, assim como os nós, são uma parte fundamental na arquitetura do hipertexto. Sua definição é baseada na existência de uma origem e de um destino, denominados nó de ancoragem e nó de destino (LAUFER \& SCAVETTA: 1991). O link consiste no elemento intermediário que chama a atenção do interlocutor através de letras ou frases sublinhadas ou marcadas por cores diferentes, advertindo-o da possibilidade da passagem de um hipertexto para outro, composto de informações complementares. Segundo LAUFER \& SCAVETTA (1991, p. 89-91), os links são “[...] colocados pela estruturação do conteúdo semântico como apoio à argumentação e à retórica do discurso" e tem a função de "[...] fornecer interativamente uma informação específica calculada, em resposta a dados selecionados, modificados ou acrescentados pelo utilizador", de maneira a proporcionar ao interlocutor o acesso à informação na seqüência, volume e formato desejados, sendo possível a alteração das estratégias de busca (BARRETT: 1989).

É possível diferenciar duas espécies de links, segundo Nielsen (1995) e Laufer \& Scavetta (1991): 
a. Links implícitos ou dinâmicos: característicos de hipertextos unidirecionais, ou seja, que se limitam a uma unidade que se referia somente a informações mais gerais. $\mathrm{O}$ próprio hipertexto era originário de um nó de ancoragem, sendo assim um nó de destino, encerrando as possibilidades de busca do interlocutor. "Os elos implícitos são colocados automaticamente, pela ativação, já não de um botão concreto, mas de uma ou várias propriedades associadas ao nó fonte e ao nó alvo: o elo é a reação do alvo à mensagem recebida na fonte [...]" (LAUFER \& SCAVETTA, 1991, p. 89);

b. Links explícitos ou executáveis: existentes em hipertextos bidirecionais, que provêm de outros hipertextos concernentes a informações menos específicas, mas que também disponibilizam o acesso por meio de nós de ancoragem a sítios que contêm temáticas diferentes ou mais detalhadas. "Os elos explícitos são colocados manualmente, ancorados num lugar preciso de um nó (uma palavra, um parágrafo, uma imagem)" (LAUFER \& SCAVETTA, 1991, p. 89).

Os links explícitos ancoram ou conectam um sistema de hipertexto a outro, indo de simples textos a outras espécies de mídias, como imagens ou vídeos. Os suportes hiper pressupõem interlocutores interativos, que sempre buscam novos horizontes e que desejam obter acesso a informações específicas e ausentar-se do domínio geral, alçando novas temáticas. Tal ligação ocorre somente se existir pertinência por parte do interlocutor e, principalmente, um aspecto associativo intermediado pelo link entre diferentes unidades de informação. Portanto, as mediações da busca de informação e a conexão com outros sítios dependem de um fator de continuidade de sentidos para ser estabelecido. O hipertexto, além de possuir a coesão e a coerência como fatores de textualidade, também se mostra organizado em sua arquitetura informativa, especificamente no que concerne ao link, o que sustenta dinamicamente o conceito de hipertexto como sendo um texto.

É possível atribuir ao hipertexto a característica de direção interpretativa ou vetor, no sentido de seduzir o interlocutor a seguir determinado caminho editado intencionalmente pelo outro interlocutor. De acordo com Burbules (cit. por CASTRO, 2001, p. 70), “[...] os links são ferramentas de retórica, ou seja, da mesma forma que carregam um interlocutor dum texto ao outro, eles também criam relações significativas que possibilitam a formação de uma rede 
semântica de informações". O link é, portanto, uma pressuposição decorrida da elaboração de imagens mentais por parte dos interlocutores e acrescenta ao hipertexto uma característica sugestiva, o que o diferencia do texto tradicional, pois este não sugere, existe para ser lido de uma só maneira. Consequentemente, como um caminho que pode ou não ser seguido, é possível observar em sítios a existência de links flutuantes, aprimoramento da tecnologia digital, em formas e cores diferenciadas e, até mesmo, na forma de figuras humanas. Isso é necessário para que as pressuposições dos interlocutores sejam paralelas e que as informações contidas em um mesmo sítio provenham deste encontro de interesses.

Assim, o link, além de conectar outros hipertextos, pressupõe, com sua existência, hipertextos que tratam de temas recorrentes no hipertexto observado. Com a capacidade de atualizar significados de maneira instantânea, ele integra coerentemente outros hipertextos. A partir de uma indicação contida em limites textuais, a sua ativação leva o interlocutor diretamente a um outro espaço, divergente daquele inicial. Assim,

O link [...] operacionaliza as imprescindíveis interseções entre textos/ discursos que já estejam hipertextualizados e, ao mesmo tempo, articula, através deles, posições disparatadas em torno de uma mesma questão, evidenciando a presença de beligerâncias e divergências intelectuais tão salutares para qualquer sociedade que valorize a livre expressão de pensamento dentro de uma atmosfera em que prevalece o Estado Democrático de Direito (XAVIER, 2001, p. 173).

Logo, os processos de leitura e compreensão são essencialmente alterados com o advento do hipertexto, pois os significados tornam-se ainda mais instáveis quando da existência do link, pois o mesmo possibilita instantânea busca pela constante (re) organização hipertextual. Portanto, o estado de conexão como característica cabal do texto em meio eletrônico remete à idéia de externo, do exofórico, já que o interlocutor é constantemente remetido a outros sítios, em um movimento de mobilidade informativa permanente. É a concretização do não-fechamento de um texto tradicional que faz do link elemento fundamental no hipertexto, pois, a princípio, sugere que fatores de textualidade, como a informatividade e a relevância (cf. de BEAUGRANDE \& DRESSLER: 1981), estejam em constante alteração.

O uso de sítios exclusivos para pesquisa, como o Google, é uma ferramenta facilitadora e que, a partir de banco de dados existentes na rede mundial, indexa outros hipertextos. A insistência tácita dos links em serem acessados procura auxiliar o interlocutor na busca e 
acesso a informações que surjam de acordo com as associações mentais ocorridas no momento da interação textual, mas que atuam interpretativamente na tarefa de compreensão textual.

Os hiperlinks [...] operam ainda como táticas retóricas de cercar um determinado problema por todas as angulações e perspectivas imagináveis em que ele possa ser visualizado e entendido, já que a indicação 'linkada' se dá geralmente entre hipertextos que tratam do mesmo tópico e, assim, se complementam ou se refutam, se reafirmam ou se contradizem (XAVIER, 2001, p. 174).

Portanto, o continuum semântico (MARCUSCHI: 1999), que determina as interligações textuais-discursivas, adquire seu ponto máximo no formato hipertextual, já que [...] os links não podem ser caracterizados como um conjunto de itens iguais. Cada interconexão, independente do contexto, cumpre um papel fundamental na movimentação dos dados na rede, como também, na formação de uma teia semântica de informações (CASTRO, 2001, p. 66).

Estas considerações levam a crer que a construção de um hipertexto diz respeito, em primeira instância, à evolução dos sistemas computacionais. De acordo com a história do hipertexto, alvo de reflexões no início deste trabalho, os primeiros textos eletrônicos eram fechados e não possibilitavam a interação com outros hipertextos, obstáculo ultrapassado devido ao desenvolvimento da tecnologia TCP/ IP, atualmente conhecida como Internet ${ }^{18}$. Por outro lado, nota-se que este desenvolvimento inviabilizou a existência de hipertextos solitários ${ }^{19}$ sugerindo, portanto, a necessidade dos editores em interligar hipertextos a partir de um referencial semântico-textual (KILFEATHER: 1998). No entanto, a possibilidade de se editar hipertextos é restrita àqueles que têm a possibilidade de fazê-lo por meio de servidores, que são máquinas apropriadas para o armazenamento de um grande número de informações. Não obstante, o interlocutor deve ter conhecimento suficiente para interligar os nós presentes nos hipertextos, fazendo do leitor um autor, já que envolve processos de seleção e conexão informativa. Consequentemente, é um processo de elaboração de coerência textual. Assim, participando da reconfiguração a partir dos links, o leitor torna-se também autor do hipertexto.

\footnotetext{
${ }^{18}$ Vide Capítulo 1: "A história do hipertexto".

${ }^{19}$ Stand alone hipertexts.
} 
Ainda de acordo com Kilfeather (1998: 65), o conceito de usabilidade no hipertexto refere-se não somente à capacidade do interlocutor em fazer uso de uma arquitetura semântica diferenciada das presentes no texto tradicional. Isso significa que “[...] a recepção apropriada do texto significa que o texto é coerente de acordo com parâmetros propostos pelo autor primário, os quais são singularmente derivados da concepção do autor acerca de como o texto deve ser recebido" ${ }^{20}$. Entretanto, notam-se na rede três tipos de hipertextos, segundo Primo \& Recuero (2004a):

- O hipertexto potencial, construído a partir da pré-disposição de links, sugeridos pelo autor, e que pode ou não ser seguidos pelo interlocutor;

- O hipertexto cooperativo diz respeito à contribuição dos interlocutores na construção hipertextual. Neste tipo de hipertexto, os links não são somente vetores unidirecionais, mas também construções múltiplas e pluridirecionais e

- O hipertexto de colagem é caracterizado como uma produção coletiva, mas elaborada por diferentes autores. Difere do hipertexto de cooperação no processo dissociado de elaboração hipertextual

Desta classificação surgem os conceitos de co-link ou link multidirecional (cf. PRIMO \& RECUERO: 2002). Estes refletem a construção participativa de um hipertexto, avançando ainda mais no conceito de autoria, já que o autor desta espécie de hipertexto é ampliado para um número incalculável de criadores. Por outro lado, observa-se que o poder nas mãos dos interlocutores é fictício, já que os mesmos seguirão para outros hipertextos através do controle dos autores. Nesta linha de raciocínio, considera-se que o link é um objeto de valor para a Internet, pois ter um elo acessível oriundo de um grande portal valoriza um determinado sítio. Os links mostram, portanto, o que há de interessante e de indispensável na rede, indicando tais características aos interlocutores por meio de recursos multimidiáticos.

\footnotetext{
${ }^{20}[\ldots]$ the "proper" reception of the text assumes that the text is coherent within the parameters set out by the primary author- which in turn is derived from a conception by the author of how the text will be received.
} 
Todavia, este conceito é oriundo da verificação de que há dois tipos de links, divergentes segundo as estruturas no hipertexto:

- Links associativos: representados por links localizados nos nós do hipertexto e que interligam hipertextos. São, em sua maioria, de acordo com Primo \& Recuero (2004), vetores unidirecionais.

- Links estruturais: indicam ao interlocutor as estruturas de navegação.

O link é uma ligação entre hipertextos. Considera-se este elo acessível como um apontador que dirige o interlocutor a outros hipertextos instantaneamente atualizáveis no espaço virtual. Isso promove a disposição informativa elencada por Huber (2005) a partir de módulos de interface agradáveis e de fácil acesso ao interlocutor. Podem ser representados por textos, imagens, sons e vídeos e atuam como funções informativas de primeira ordem. Isto significa que o autor coloca ao leitor aquilo que ele pressupõe que seja de maior importância em um hipertexto.

Ainda de acordo com Huber (2005), consideram-se as diferenciações formais entre links de acordo com os seguintes critérios:

1) direcionalidade, sendo que é possível observar a existência de links unidirecionais e bidirecionais. Os primeiros referem-se a uma direção única, na qual são claramente determinados os nós de âncora e de chegada, ao passo que o segundo concerne ao papel de duplicidade exercido pelo link e

2) Advém daí a diferenciação baseada na localidade e globalidade, referentes ao potencial de um link em interligar diferentes estruturas textuais e diferentes nós, respectivamente. Podem ser dividas em: global-global; global-local; local-local e local-global;

3) Concernente às divergências com relação aos conteúdos dos links tem-se, de acordo com Conklin (cit. por HUBER, 2005, p. 58), a) links referenciais ou associativos: interconexões implícitas e imprevisíveis pelo autor do hipertexto, que não constroem unidades 
hierárquicas de sentido e b) links organizacionais ou tipificados: caracterizam-se por meio de relações semânticas e argumentativas explícitas;

4) Já com relação ao aspecto da transposição de páginas, os links podem apresentar nós: a) em uma mesma janela e b) em janelas diferentes.

Realizadas as considerações para a elaboração de uma teoria referente ao link alocado em hipertextos, demonstrou-se que o paradoxo entre as estruturas rizomáticas presentes na rede mundial de computadores e a caracterização do hipertexto como um texto coerente complementam-se. Ademais, discorreu-se sobre diferentes tentativas de observação e organização do hipertexto com o objetivo de esclarecer a construção e uniformidade de sentidos entre nós e links.

Estas considerações serão confrontadas com pressupostos advindos da prática jornalística, que se confirmam através de linhas editoriais sustentadas, explícita ou implicitamente, em todos os seus gêneros discursivos. O jornalismo refere-se à comunicação intermediada por fatores editoriais, o que significa que um de seus produtos, no caso o hipertexto noticioso, advém de uma realidade intermediada e construída a partir de referentes reais, mas circunstanciados e perspectivizados de acordo com os interesses dos jornais.

De acordo com as características relativas à Internet e ao hipertexto, a realidade fabricada pelo jornal pode ser destituída por meio do acesso instantâneo a outras informações promovido pelos links. A desconstrução do discurso jornalístico dá-se por meio da leitura não de outros referentes, mas de outras circunstâncias que veicularão um fato a partir de outros pontos de vista. Desta feita, a análise textual dos links no âmbito do hipertexto noticioso não visa somente caracterizá-lo como um operador de coerência textual, mas também como um promovedor de sentidos a partir da perspectiva do jornal.

Essas considerações serão discutidas nos capítulos seguintes. 


\subsection{O fazer jornalístico}

Em primeira instância, ao se discutir aspectos do texto noticioso e da prática jornalística, é necessário discorrer acerca da definição de verdade. Relatar a verdade e ser o porta-voz dela é o papel do jornal. No entanto, esta pesquisa vê-se diante da necessidade de delimitar este conceito e, consequentemente, de colocar em discussão o mito da objetividade preconizado pela imprensa. Estas críticas estender-se-ão à definição do lugar ocupado pelo jornal na sociedade moderna e às estratégias de construção do texto noticioso.

A verdade, segundo Lage (2001), é um conceito abstrato que é representado por meio de símbolos e/ou exemplos da realidade. No entanto, esta representação é subjetiva e oriunda de atividades experimentais do sujeito com o cotidiano no qual vive. Apreende-se, portanto, que verdades e fatos não se circunscrevem ao mesmo escopo teórico, já que fatos são acontecimentos vivenciados por um sujeito e que podem ser recontados a partir de uma determinada perspectiva. Assim, há uma transformação processual que envolve a passagem da abstração simbólica para uma administração factual gerida de acordo com aspectos estratégicos de narrativa. Logo, há uma mediação entre o que aconteceu e a comunicação do ocorrido.

Esta mediação dá-se por fatores intrínsecos à linguagem, não sendo, portanto, exclusividade da prática jornalística. Primeiramente, a própria língua e, adiante, os fatores de seleção e ordenação informativa, ou seja, a estrutura e conteúdo do texto é que formalizam um texto jornalístico. Contudo, são eles que dão as características ao texto noticioso, pois estão aliados a interesses e linhas editoriais, entendidas aqui como valores e opiniões defendidas por instituições midiáticas. Estabelecem-se relações de poder entre interlocutores, nas quais os jornais mostram aos interlocutores o que é relevante e determinante, ou seja, passível de comunicação. Este valor informativo é o que Dines (1990) chama de "criação de circunstâncias para uma notícia”. Já Lage (2001) define este processo criativo de “competência". Afirma-se aqui, no entanto, que se a verdade é uma abstração concretizada no relato de fatos, a notícia é um relato consubstanciado em estratégias cognitivo-textuais de ressignificação de acontecimentos que são alvo de transformações minuciosas e que buscam abarcar a relação entre jornal, sociedade e interlocutor. 
O jornalismo faz uso de textos caracterizados como interpretativos, isto é, aqueles que criticam e analisam a realidade, e noticiosos, que se caracterizam como informativos, ou seja, aqueles que informam e interpretam a realidade (KUNCZIK: 2000). É comum observar que os primeiros são os denominados editoriais, que expõem a opinião do jornal e se encontram separados do restante da pauta, para que o interlocutor possa reconhecer melhor a divisão entre opinião e realidade, mundo comentado e mundo narrado.

É possível notar, portanto, também nos textos noticiosos graus de subjetividade e influência editorial que procuram persuadir o interlocutor de que as informações ali contidas são únicas e verdadeiras. O jornal como veículo de comunicação e informação oferece

[...] facilidade e detalhamento de informações, variabilidade e dosagem de assuntos e, conseqüentemente, objetividade, seriedade e respeito à necessidade de conhecimento do que vai pelo mundo. Ao término da leitura informativa diária, esse privilegiado destinatário sente a tranqüilidade de estar informado e, pela sua própria capacidade de julgamento, apto a formar opiniões sobre os fatos (BRAIT, 1991, p. 87).

Os textos noticiosos, além dos opinativos, são de grande importância para a veiculação das idéias condizentes com a opinião do jornal, pois mobilizam inúmeros mecanismos que transparecem objetividade, tais como citações e estatísticas, além de estratégias textuais que demonstrem imparcialidade (MOSCA: 1994). O jornalista e a equipe da redação impõem ao interlocutor valores de verdade que são obtidos por meio de estratégias discursivas que resultam em efeitos de sentidos interpretados pelo interlocutor.

De acordo com Mosca (1992), o jornal se instituiu historicamente como um sujeito social portador de valor e prestígio, veiculando inicialmente textos informativos e que, após o surgimento de outros meios de comunicação mais dinâmicos, viu-se diante da necessidade de se constituir como um canal interpretativo, formado de textos opinativos e noticiosos condizentes com uma determinada linha editorial. Aliada à esta evolução histórica, o jornal faz uso de estratégias lingüísticas que buscam eliminar o conceito de interlocutor. "O leitorpadrão-imaginário não dá opinião, ele é apenas um alvo para o qual se destina o processo" 
(DINES, 1986, p. 21). Assim, o jornalismo é construído de modo a transformar o interlocutor em um receptor contra-argumentativo.

Por outro lado, nota-se uma rapidez extraordinária na comunicação dos fatos, plenamente observável nos eventos transmitidos em tempo real pela televisão e também pela rede mundial de computadores, a Internet. $\mathrm{O}$ rádio também tem esta possibilidade, porém veicula suas notícias somente por meio da voz, sem fazer uso de imagens ou figuras. Este viés tecnológico acabou por criar uma espécie de concorrência entre os meios de comunicação, principalmente entre o jornal impresso e a televisão. Logo, o primeiro viu-se diante de um desafio, que o obrigou a alterar seu perfil a fim de que não se dirigisse à inutilização. Em meados da década de 60, anos que marcaram o crescimento do televisor como eletrodoméstico, o noticiário em papel alterou de maneira significativa seus ideais, particularmente no que concerne ao modo de se escrever as notícias. A mídia pura e simplesmente descritiva de fatos deu lugar a um jornalismo impresso crítico e analítico, que chegasse aos seus interlocutores como opiniões discutidas e estagnadas. "Há no bojo da relação jornal-leitor certa cumplicidade, um contrato de credibilidade, um acordo quase tácito entre ambos, uma vez que o leitor delega àquele a faculdade de julgar em determinadas questões como profissional de opinião" (MOSCA, 1994, p. 232).

Os interlocutores atribuem um valor idealístico a todos os discursos presentes na pauta jornalística. Desta forma, os diversos gêneros jornalísticos que podem ser encontrados no jornal impresso, tais como reportagem, notícia, editorial, entrevista etc., não são mais abarcados de acordo com a dicotomia opinativo e informativo, estes gêneros complementamse de modo a construir um veículo único de sentido, nos quais se refletem as opiniões do jornal. Logo, o jornal mostra-se como a porta voz da realidade, a guardiã da informação e da veracidade e também como uma fábrica de realidades (MOSCA: 1994).

A expectativa de que os veículos de comunicação sejam o único modo de se ter contato com os acontecimentos também os classifica como um agente da realidade, que traz o mundo em papéis descartáveis. Em um espaço de crítica e análise, esta caracterização adquire um status de incapacidade por parte do interlocutor de dialogar com os fatos, pois o mesmo tem em mãos opiniões prontas. Contudo, esta inércia também está localizada nos textos noticiosos, 
que trazem em seu bojo a interpretação da realidade transformada a partir da informação. "[...] Ao eliminar essa relação conversacional do eu em face de um tu, o jornalismo se permite à inserção num outro campo em que o resultado do dizer se torna informação incontestável, pois não supõe uma réplica, mas a mera absorção" (GOMES, 2001, p. 65).

Os fatos e acontecimentos são produtos da realidade e pertencem ao mundo real, ao vivido, já os textos jornalísticos pertencem ao gênero do comentado, analisado e criticado. Apesar de a informação atuar como base para a criação de um texto, que é também uma exigência do interlocutor, ela está inserida como uma espécie de máscara para que os julgamentos e valores do jornal possam atuar. Alicerçado à necessidade do interlocutor de se manter informado, pois “[...] Para existir notícia é preciso que haja primeiro uma informação de interesse universal" (LUSTOSA, 1996, p. 18), controla-se a opinião e a discussão dos receptores dos textos noticiosos por meio do discurso jornalístico. Assim,

[...] a informação oferecida pelo jornal é, antes de tudo, um fato discursivo, isto é, de que a realidade se constrói no texto e pelo texto e de que o jornal tende a construir o seu próprio referente ou 'opções de realidade'. Segundo essa hipótese construtivista, o discurso não apenas reproduz o real, ele o constrói, não apenas reflete o social, mas o produz (MOSCA, 1993, p. 261).

Portanto, por meio do texto e com o "[...] grau de controle da informação" (UETANABARO, 1991, p. 99), são inseridos na notícia a voz institucional do jornal e a intencionalidade do jornalista, filtrada pelas quatro camadas propostas por Esser (1998): sociedade, mídia, instituição e subjetividade. “[...] O texto jornalístico, assim como os demais textos, tem um destino interpretativo, atua segundo estratégias e configura-se como uma cadeia de recursos expressivos" (BRAIT, 1991, p. 85).

O texto noticioso, ao contrário de "[...] uma conseqüência natural de transparência característica de uma linguagem capaz de revelar os fatos sem mediação, ou seja, mimetizando o real" (BRAIT, 1991, p. 87), informa o interlocutor a partir de categorias e técnicas, aparentando objetividade e imparcialidade. Tendo início tal processo pela manchete e pelos subtítulos, na página mesma que se encontra a notícia, que em primeiro lugar, atrai a atenção do interlocutor, com enunciados resumidos e concisos, além de possuir uma função 
estética. Porém, a informação é transformada em notícia mediante o uso das técnicas de jornalismo ou de redação jornalística. Técnica é a capacidade de alguém produzir um trabalho com a utilização de materiais e instrumentos que tornem eficientes os resultados que pretende alcançar (LUSTOSA, 1996, p. 18).

A técnica elencada por Lustosa (1996) é tomada aqui como sinônimo de construção textual e a ferramenta mais adequada para alcançar os resultados que pretende o jornalista são os efeitos de sentido veiculados no texto noticioso. Em meio às informações em um gênero do vivido, o jornal constrói textos que interpretarão a realidade de acordo com a opinião da redação. Portanto, faz-se uso de estratégias textuais para que o fato seja veiculado com um significado único para o interlocutor. A interpretação da realidade dá-se pela construção textual dos referentes, que adquirem um continuum de sentidos e que acabam por transmitir a notícia.

\subsubsection{As camadas de influência do jornalismo}

O conceito de notícia, segundo Lage (2001), é o relato de fatos importantes a partir de um fato, com a função de atualização e que instaura um determinado conhecimento. Esbarrase no conceito de importante. Na esteira da relevância das notícias para uma determinada sociedade ou público-leitor, segundo Zipser (2002), a elaboração de sentidos em um texto está ligada à realidade na qual vive o jornalista. Assim, o jornalismo de cada país é marcado pelas condições emoldurais sociais gerais, por fundamentos históricos e jurídicos, limitações econômicas, bem como por padrões éticos e profissionais de seus agentes.

Isto é, um texto jornalístico não pode ser considerado neutro, desde que seja escrito por um indivíduo que se encontra socialmente imerso, pois está sujeito a todas as transformações ocorridas e ocorrentes em seu país. Afirma que o público também exerce influência sobre o jornalista. Neste contexto, o jornalista redige um discurso ligado ao leitor e este, por sua vez, "dita" ao editor como escrever um texto. Se o destinatário dispõe de um tempo escasso para a leitura de jornais, o jornalista deve fazê-lo de modo conciso. Se o inverso ocorrer, o mesmo poderá elaborar um texto mais longo e analítico. 
Esser (1998) estuda em sua obra os diferentes níveis de influência que um jornalista pode sofrer ao elaborar seu texto. O autor utiliza-se da "metáfora da cebola", na qual as diversas cascas desse bulbo são comparadas aos níveis de influência que um jornalista pode sofrer. São eles:

- Camada social: encontra-se imersa em todo indivíduo que habita um país ou uma nação; portanto, todos são influenciáveis por ela;

- Estrutura da mídia: "são as condições econômicas do mercado da mídia, o direito de imprensa" (p. 26);

- Instituição: a liberdade de cada redação e seus aspectos éticos;

- $\quad$ Subjetividade: os valores de cada indivíduo.

Estas esferas "dão ao jornalismo os elementos que determinarão sua identificação com o contexto específico no qual ele está inserido [...] resultado da interação entre as várias esferas de fatores" (ZIPSER, 2002, p. 28). As cascas da cebola são interdependentes, ou seja, cada uma incide sobre a outra em camadas superpostas.

A seleção e ordenação informativa é um dos reflexos concernentes à passividade do jornal e, consequentemente, do jornalista, aos níveis de interferência sócio-instituicionais. Considerando-se o jornal como uma instância mediadora entre os fatos empíricos e a comunicação de um mundo relevante a uma determinada sociedade, nota-se que há uma elaboração estratégica do texto noticioso. Esta construção minuciosa refere-se à existência de uma realidade multifacetada e que pode ser observada a partir de diferentes pontos de vista, sendo uma fonte inesgotável de acontecimentos a serem intermediados e noticiados a um público-leitor (LAGE: 2001).

\subsubsection{Fatores de produção do texto noticioso}

De acordo com Lage (2001), a orientação por dois aspectos que sustentarão a linha editorial de um jornal: a importância ou o interesse, mas considerados em consonância com 
pesquisas de mercado que detectam as evoluções sociais e demonstram o interesse de leitura por parte dos interlocutores.

Em termos empíricos, os aspectos que se mostram cruciais na produção do texto noticioso referem-se às necessidades colocadas pelo público-leitor de um determinado jornal e que circunscrevem tanto fatores relacionados ao interesse como aos gostos pessoais destes leitores. Assim:

- Proximidade: tática de tornar relevante uma notícia para determinado público consumidor. Preconiza-se uma intermediação entre os formadores de opinião e a criação da relevância para a notícia;

- Atualidade: tem relação com o conceito de transatualidade, que diz respeito à máscara que encobre os fatos da atualidade, mas que se originam de acontecimentos que atuam como paradigmas para fatos atuais, atribuindo relevância à notícia;

- Identificação social: relativo às pirâmides sociais, trata-se da tentativa do jornal em ampliar o seu público-leitor, atendendo a demandas consumistas em um processo retroalimentativo iniciado nas camadas mais privilegiadas da sociedade. Baseada na renovação e envelhecimento de formas, o jornal reinventa-se permanentemente a fim de não se encontrar em disparidade aos interesses de uma determinada sociedade. De acordo com Lage (2001, p. 52), os jornais “[...] tendem a evoluir da mesma maneira; será sempre mais fácil retocar a diagramação, que é a forma, do que a técnica de produção do texto [...]”.

- Intensidade: referente às propriedades empíricas de um acontecimento. $O$ impacto de um texto noticioso é mais amplo quando do tratamento dado a estes aspectos de forma a atender às opiniões editoriais de um jornal. As circunstâncias criadas pelo jornalista é que orientarão a intensidade de uma notícia, tornado estes empirismos marcas estratégicas na mediação do mundo real e do mundo textual; 
- Ineditismo: concernente à probabilidade de acontecimentos e, consequentemente, à construção do texto noticioso a partir de elementos que estabeleçam uma linha mediana entre aquilo que é absolutamente improvável e o que é plenamente previsível. Com fins de ampliar o público-leitor, o jornal procura enfatizar os fatos a partir de uma perspectiva de equilíbrio de possibilidades e previsibilidades, ostentando uma mediatriz entre $o$ conhecimento do público e os fatos ocorridos no mundo. Há casos em que este intermediário transpõe-se a notícias extremas, nas quais o saber cotidiano é extrapolado devido a acontecimentos inéditos;

- Identificação humana: a potencialização de feitos por personalidades que sempre buscam os limites sugeridos ao próprio homem, sugerindo uma criação imagética que os torne estereótipos. O surgimento destes tipos padronizados faz de seus atos acontecimentos universais, atribuindo importância crucial às suas idéias e opiniões.

De acordo com os fatores acima elencados, observa-se que as técnicas de produção do texto noticioso levam em conta aspectos não referentes somente ao espectro textual, mas também ao relacionamento direto e intrínseco com a sociedade na qual se encontra o jornal. Os conceitos de importância e relevância não dizem respeito somente ao texto, mas também à reciprocidade entre público-leitor e jornal.

Neste contexto de relações entre sociedade e jornal, o texto noticioso será a concretização desta gama de intermediações transposta ao jornalista. Desta feita, faz-se necessário discorrer acerca do hipertexto noticioso, o qual se pressupõe que se estabeleçam outros tipos de relações entre o jornal e a sociedade. Consequentemente trata-se de uma máquina inédita e que é um instrumento de acesso para, até então, o maior banco de dados aberto e acessível. Logo, é fundamental especular como a problemática da acessibilidade, preconizada pelo manuseio do papel em contraposição ao contato com o computador, pode vir a influenciar a construção do texto noticioso.

Em segunda instância, é necessário investigar como o jornalismo vem se desenvolvendo neste ambiente eletrônico, formado a partir de tecnologias hipermidiáticas e hipertextuais. A 
partir da investigação feita acerca da práxis jornalística no âmbito impresso, estes conceitos serão aplicados a fim de se discorrer sobre as características do jornalismo online.

Adiante, para se formalizar ambas as propostas, observa-se que houve um período de transição entre o início do webjornalismo e a sua consolidação, primeiramente, como alternativa ao jornalismo impresso e depois como prática eletrônica. As características desta transição e alguns conceitos que foram alvo de mudanças nesta transformação serão discutidos no capítulo seguinte.

\subsection{O jornalismo impresso e o webjornalismo: semelhanças e diferenças}

Neste capítulo, serão abordadas as principais diferenças na transição do jornalismo impresso para o jornalismo online, enfatizando a inexistência, na rede mundial, de limites temporais e espaciais. Serão feitas alusões a um novo conceito de texto que surgiu com a disseminação de informações e escritos pela Internet, no caso, o hipertexto. Este se revela como um objeto de comunicação virtual que se dá através da construção de um texto nãolinear. Ao contrário do que afirmou van Dijk (2002), baseado no estudo empírico das técnicas de produção do texto jornalístico impresso, de que toda categoria originará um subordenado menos importante, isso não é uma condição sine qua non no hipertexto noticioso baseado na não-linearidade textual.

A comunicação "todos-todos", imaginada por Lévy (1999), prevê um novo dispositivo que ignoram barreiras de qualquer espécie. A inteligência coletiva pode adquirir novas formas. As categorias de emissor e receptor são potencializadas, assim como o meio torna-se volátil e móvel, sem mediações onipotentes. Há a possibilidade, então, da elaboração de uma memória coletiva global e não mais local e restrita de acordo com limites estruturais. Os atos, antes culturais, agora podem ser caracterizados de acordo com os aspectos de cooperação e dinamicidade, e (re) interpretados constantemente e em tempo real. Daí a idéia de nãolinearidade, ausência de hierarquia e mobilidade de centros. A definição de hipermídia baseiase na apresentação da linguagem não-verbal existente na rede e que pode ser intercalada com o hipertexto. Tecnicamente, 
[...] é um tipo de programa para a organização de conhecimentos ou dados, a aquisição de informações e a comunicação. $\mathrm{O}$ sistema de hipertexto é aquele que permite autores ou grupo de autores fazer uma interconexão de informações, criar caminhos ou atalhos através do corpus material relatado, tomar nota dos textos existentes e criar notas que apontem a o leitor os dados bibliográficos ou o corpo do texto citado, com o simples clicar de um mouse num determinado ícone, palavra ou qualquer outra espécie de link (FERES, 2001, p. 36-37).

O conceito atual de jornalista intersecciona-se com o conceito de interlocução naquilo que Medina \& Greco (1994) denominou de mediação trialógica. Esta transcende o informador e escritor e aporta no promovedor de personalidades que ajam, pensem e criem situações complexas de comunicação. É a interpretação de um fato e o equilíbrio de poderes que nela atuam. É mais do que um mediador, mas um sujeito socialmente imerso e, ao mesmo tempo, fora da sociedade na qual vive, o que lhe possibilita a compreensão e a crítica da mesma. É aquele sujeito que faz a ligação entre o local e o universal, especula e faz especular. Isso traz a obrigação de renovação jornalística, pois transpor aquilo que de mais importante foi impresso não é o suficiente. A mudança deve se localizar nas e devido às ofertas do ciberespaço.

Com o advento da rede mundial de computadores, o jornalismo passou a exercer a sua função de maneira praticamente instantânea, sendo que alguns portais, como o Último Segundo, atualizam os fatos comunicados de um em um minuto. Outros, no caso o sítio do jornal O Estado de São Paulo, abriga em seu banco de dados edições divulgadas por meio online desde o ano de 1996. A rapidez com que as notícias são divulgadas pela rede - fator este que procura acompanhar o sucesso que as redes mundiais de televisão obtiveram e ainda hoje obtêm na disseminação de fatos - alterou de forma significativa a maneira de fazer jornalismo e, principalmente, as técnicas redacionais empreendidas ao se elaborar um texto jornalístico.

Atualmente, o jornalista ou mediador trialético deve promover a notícia, pois os meios são muitos, o que propicia o fluxo informativo, porém a mediação fica aquém das expectativas. Isso dá margem ao aparecimento de um jornalismo interpretativo ainda mais contundente. $\mathrm{O}$ desgaste das formas proeminentes é excessivamente rápido, fazendo com que a prática jornalista altere-se, principalmente, no âmbito da linguagem. Assim, novas posturas devem ser elaboradas, a ponto de dialetizar o local e o universal, com um linguajar marcado por um microuniverso literário, expressando situações e conseqüências. O interlocutor é colocado em uma situação de conflito, na qual reinam a polissemia, a polifonia e a 
intertextualidade, a interatividade entre os interlocutores, os temas, os valores, o ato interpretativo e a coerência. Vale, neste momento, o conhecimento do simulacro, ao passo em que a atualização em tempo real distancia o indivíduo do saber, promovendo o processo de arquivamento da memória. Outros mundos sociais, cognitivos e práticas surgem com o advento da informática.

Algumas características do jornalismo atual, de acordo com Medina \& Greco (1994), são: narrativa complexa do real, a partir do engendramento das perguntas básicas ratificadas pelas práticas jornalísticas (quem, o que, quando, como e por quê); capacidade de dar mais informatividade ao texto, procurando evitar a fuga do interlocutor, a fim de interpretar e relacionar dados divergentes; abandonar a linha editorial monológica de determinado jornal e partir para o trialético, para o diálogo interpretativo, para o analítico, tornando o discurso jornalístico polifônico e mediador de debates. Assim,

[...] se o mediador procura vozes pluralistas- dos anônimos oscilantes, aos portadores do discurso do poder e àqueles críticos que lhe fazem oposição- e as faz representar nas suas reportagens, processa-se, pela mediação do discurso do jornalismo, a comunicação trialética: emissor de mensagens, mediação social e recepção, que se interagem alimentadas pelo tônus participativo (Medina \& Greco, cit. por FERES, 2001, p. 58).

Partindo-se do ético e do técnico, aporta-se nas novas formas e no novo estético. $\mathrm{O}$ conceito de informação é revisto com o advento das novas tecnologias, já que neste novo suporte está livre de intervenções institucionais poderosas.

A informação cooperativa na rede adquire status de alterador da prática jornalística atual, dado o papel dos links, que conectam dados e promovem o contato entre diferentes textos, na medida em que tecnologias são desenvolvidas com o intuito de proteger o conteúdo elaborado. $\mathrm{O}$ acesso aos dados, no entanto, é livre.

Por um lado, as novas tecnologias diminuíram os custos com a comunicação e aumentaram a eficiência dos jornalistas para produção de suas reportagens e entrevistas. Por outro, ao facilitarem o acesso à informação, os novos sistemas trouxeram consigo um dos maiores problemas que é a fartura de dados disponíveis aos jornalistas e pesquisadores (FERES, 2001, p. 83). 
Os fatos percorrem o globo com a velocidade de alguns segundos e tendo como conseqüências reações tão rápidas quanto a produção das notícias, que por sua vez, desencadearão outros textos jornalísticos, alterando assim, as formas de construção e não mais as decisões sobre o tecer jornalístico, como as reuniões de pauta tão conhecidas no jornalismo impresso. "[...] As informações, mais do que as decisões alteram os dados e os fatos da crise" (CHAPARRO, 2001, p. 32).

Considerando-se as características principais da rede mundial de computadores, uma das quais é a ausência de limites espácio-temporais, não existe para o jornalismo online um tempo passado ou um tempo futuro (MINGORANCE: 2002), mas somente o agora, o instantâneo, o momentâneo. Em meio a uma avalanche de informações, não há tempo para a reflexão sobre os fatos. Segundo entrevista dada por Alcides Ferreira, editor da seção eletrônica Economia da Agência Estado, em Chaparro (2001), para o profissional jornalista de meio eletrônico, a grande parte da notícia veiculada pela rede é a transcrição daquilo que os discursos oficiais proferem, não havendo assim, o espaço crítico e interpretativo que caracteriza o jornal impresso. Logo,

[...] Cria-se, então, a estranha contradição: a empresa, a sociedade e a atualidade exigem do jornalista, cada vez mais, a capacidade intelectual de compreender, para explicar, o complicado mundo circundante; entretanto, ao jornalista se impõem circunstâncias e condições de trabalho que inibem nele o exercício da capacidade pensante (CHAPARRO, 2001, p. 45).

O jornalismo impresso vem sofrendo uma espécie de ameaça em relação ao jornalismo online. Nas questões bombardeadas pela especulação noticiosa, o que ocorreu há alguns minutos já é desinteressante, levando o jornalismo impresso diário a um desafio de criatividade e argumentação. “[...] O jornalismo dos jornais diários precisa descobrir a lógica motivadora das perguntas e inquietações do 'amanhã' (CHAPARRO, 2001, p. 58)”. Com a possibilidade de se fazer jornalismo instantâneo à ocorrência dos fatos, o comentário e a avaliação não se encontram mais em amálgama com as notícias e é exatamente este fator que o jornalismo impresso tem, ainda, como uma espécie de "vantagem". 
No escopo das diferenciações e influências entre o jornalismo impresso e online, Jarufe (2000) afirma que a rede mundial de computadores impôs um novo parâmetro a um fator já existente no jornalismo impresso: o tempo real (CHAPARRO: 2001). Procurando assimilar o sucesso que a televisão obtém com os seus respectivos interlocutores. No entanto, a rede de computadores necessitou desenvolver um mecanismo interativo que atendia às necessidades do internauta, apoiada em suas ilimitações concernentes ao ciberespaço, onde não existem barreiras de tempo e espaço, como se este fosse um mundo paralelo sem as principais preocupações que afetam os habitantes do mundo real. No entanto, os reflexos sentidos na elaboração textual de uma notícia jornalística não se devem somente ao fator tempo, mas também no que concerne ao surgimento de um tipo textual inédito, no caso, o hipertexto.

Como o próprio nome já indica, o hipertexto tem uma grandeza insuperável em comparação com o texto impresso, pois utiliza inúmeros efeitos midiáticos, como imagens, voz, animações, sons e até a interatividade obtida por meio de câmeras instaladas no próprio computador. Assim, os efeitos de sentido antes conseguidos somente por meio de textos, são agora delineados com o auxílio de tecnologias que circunscrevem o ser humano nas suas mais diferentes necessidades. Consequentemente, com base em estruturas não presentes exclusivamente por dispositivos textuais e sim suportadas em links, o texto impresso, formulado especialmente para visualização online obtém perdas significativas. Os títulos são mais curtos e os textos de apoio usados “[...] somem nas páginas virtuais” (JARUFE, 2000, p. 55). Assim, os títulos tornaram-se mais resumidos e os textos mais espaçados e escassos de informatividade, já que o interlocutor necessita de informações rápidas e instantâneas, de modo que as páginas carreguem rapidamente. Estas pressuposições são confirmadas de acordo com uma das definições de hipertexto aqui utilizadas:

[...] Um hipertexto é um conjunto de dados textuais, computadorizados num suporte eletrônico, que podem ser lidos de diversas maneiras. Os dados estão repartidos em elementos ou nós de informação, equivalentes a parágrafos. Estes elementos, em vez de estarem ligados uns aos outros como as carruagens de um comboio, estão marcados por elos semânticos que permitem passar de um para outro, sempre que o utilizador os ativa. Os elos estão fisicamente "ancorados" em zonas, por exemplo, numa palavra ou frase (LAUFER \& SCAVETTA, 2001, p. 5). 
Com o advento da produção de hipertextos noticiosos, a linguagem jornalística começou a sofrer uma ameaça comum em relação ao hipertexto: desintegração dos objetivos, isto é, a substituição de objetivos relativos a texto mais amplo e crítico por um construído a partir do suporte de links. Em razão destas ancoragens semântico-textuais, o hipertexto noticioso tem a possibilidade de ressaltar indicações que atribuem a este texto diferentes possibilidades, ausentando-se de uma estrutura linear.

O hipertexto traz à tona um novo conceito de texto e também uma nova maneira de leitura. Em um texto impresso, o interlocutor também tem a opção de partir para a leitura de textos de apoio ou do texto principal, bem como negá-la. Entretanto, esta conjuntura textual demonstra-se infinita no hipertexto, visto que a Internet disponibiliza uma quantidade incalculável de textos a serem consultados. Portanto, a partir de uma estrutura linear discursiva, o hipertexto caracteriza-se por uma amarração semântica não-linear, sendo visualizada ou não de acordo com a vontade do interlocutor, ao contrário do texto impresso, que pode incluir muitos desses links no próprio corpo do texto. ${ }^{21}$ A existência do link é indicada por uma característica física da zona que o contém; por exemplo, uma palavra ativável estará escrita a negro ou inserida dentro de um retângulo (LAUFER \& SCAVETTA: 2001).

Desta feita, o jornalismo está adquirindo características condizentes com a rede mundial de computadores, principalmente com o uso do hipertexto. Apesar das notícias não serem aprofundadas de maneira parecida ou igual ao jornalismo impresso, a Internet disponibiliza ao interlocutor uma infinidade de textos a serem livremente consultados. Além disso, uma diversidade de fatores concernentes à produção e recepção do jornalismo online foram elencados por Zamora (cit. por MINGORANCE, 2002, p. 40):

1. Digital - é acessível por qualquer interlocutor que possua ou tenha acesso a um computador;

2. Leitura Hipertextual: a informação não é linear, como no texto impresso, mas sim, escolhida à gosto pelo interlocutor;

\footnotetext{
${ }^{21}$ Prática amplamente observada nas revistas semanais.
} 
3. Distribuição Mundial: o alcance do jornalismo online é mundial, ou seja, não somente restrito à cultura de determinado país;

4. Instantâneo: a atualização e o acesso são realizáveis em poucos segundos;

5. Interatividade: a comunicabilidade entre o jornal e o interlocutor é muito mais próxima e tecnológica do que aquela realizada no jornal impresso;

6. Personalização: o jornalismo online tem mecanismos de reconhecimento das preferências de cada interlocutor;

7. Disponibilidade: não há limites para o armazenamento de informação;

8. Multimídia: é o uso de tecnologias que visam a persuasão do interlocutor de que o jornalismo online é mais dotado de informações.

9. Confiabilidade: é um fator transposto do jornalismo impresso, o qual o sítio daquele jornal confiável também o será para o navegante; além disso, o texto é também um produto cognitivo e, portanto, imprime o conhecimento acerca de um determinado tema;

10. Serviços Gratuitos: ao contrário do jornalismo impresso, a rede mundial disponibiliza informações gratuitas;

11. Uma nova linguagem: a apresentação das telas e não das notícias em uma mesma página é dada em ordem de importância, assim como van Dijk (2001) descreveu a macroestrutura da notícia impressa.

Consideradas estas características, a rede mundial oferece muito mais opções do que um composto de folhas de papel, além da sua arquitetura hipertextual, pois

[...] quanto mais explícitas as idéias e mais claros os argumentos do autor pelos aparatos sígnicos, maior será o estímulo à participação e ao engajamento do leitor no processo de apreensão da significação. Ele achar-se-á muito mais instigado, verdadeiramente compelido a descobrir a proposta de sentido lançada pelo autor no hipertexto, já que poderá contar com 
outros meios simbólicos que não apenas o lingüístico para consignar seu intento de leitura (XAVIER, cit. por MINGORANCE, 2002, p. 84).

O advento do hipertexto e sua relação com a prática do jornalismo midiático implica considerar alguns pressupostos acerca da notícia jornalística e sua configuração. Partindo da exposição teórica acima, pode-se afirmar que o hipertexto traz em seu bojo o fator lateralidade ou coexistência textual ou intertextualidade. Textos são, portanto, quase que instantaneamente atualizados e constantemente (re) organizados. Portanto, por meio dos links, é possível acessar não somente outros hipertextos, mas também, e especialmente no caso do webjornalismo, outras hipermídias, que se caracterizam como textos não-verbais, ou seja, sons, imagens, vídeos e, futuramente, mídias que atuarão no paladar, tato e olfato. Há uma nova maneira de organizar a informação, o que pode vir a influenciar a maneira de escrever um hipertexto noticioso.

Segundo Bardoel \& Deuze (2000), o jornalismo online apresenta quatro características:

1) Hipertextualidade: dado o suporte no qual se encontra, o jornalismo possui todas ou até mais facilidades possibilitadas pelo ambiente telemático;

2) Multimidialidade: é o fator de junção entre o hipertexto e as diferentes hipermídias, aspecto de crucial importância para a informatividade;

3) Interatividade: no que diz respeito a tipologias textuais, o texto jornalístico, que tem por função interpretar fatos e acontecimentos, este fator pode ser subdividido em:

a. Interatividade argumentativa: faz com que o interlocutor permaneça na continuidade de sentidos elaborada por determinado veículo informativo;

b. Interatividade exploratória: links que são formulados para que o interlocutor rompa com os discursos ali presentes, fazendo emergir a diversidade de interpretações; 
4) Personalização: é a maneira de aprimorar ainda mais a oferta de organização ao interlocutor. Dado o excesso de informações presentes em um sítio jornalístico, o editor possibilita a escolha por parte do interlocutor daquilo que ele deseja ler;

5) Memória (PALÁCIOS: 1999): a tarefa de arquivamento e acesso a dados é acessível quando se trata de hipertextos noticiosos. Assim, o processo de busca por notícias, feitas a partir de uma ferramenta disponibilizada pelo próprio sítio, possibilita que o interlocutor tenha contato com mais informações acerca de determinado tema e

6) Atualização contínua: referente às facilidades propiciadas pela tecnologia informática, os jornais online têm seu conteúdo alterado permanentemente, de modo a acompanhar os fatos e acontecimentos em tempo real, assim como a televisão o faz.

Os seis fatores elencados acima sugerem que a interatividade entre o interlocutor e a interpretação dos fatos elaborados por este ou aquele jornal seja muito mais próxima, o que pode tornar a credibilidade do jornal algo mais frágil e passível de críticas ${ }^{22}$. Se antes o jornal possuía uma imagem mais determinante, dada a sua linha editorial e a construção textual dos valores ali apresentados como verdades incontestáveis, atualmente elas podem ser relativizadas ou dialogadas, dado o grande número de informações passíveis de acesso. Daí a necessidade de produção jornalística sujeitar-se à ausência de limites espácio-temporais, o que acaba por extravasar todos os limites já conhecidos nos diversos veículos da mídia tradicional.

Esta problemática remete ao papel do link no jornalismo hipertextual, já que o jornalismo trabalha como interpretador dos fatos no mundo e, portanto, é uma atividade que reinterpreta e cria uma outra realidade, para que o interlocutor absorva-a, aparentemente, de modo integral. Assim, segundo Gouazé (cit. por MIELNICZUK \& PALACIOS, 2001, p. 7):

"[...] o jornal, com sua forma textual de apresentação fragmentada, é o modo através do qual a atualidade é apresentada e é assim que ele, o jornal, constitui-se em uma unidade. A forma do jornal seria a condição de existência da atualidade. Sendo assim, a escrita sobre a página do

\footnotetext{
${ }^{22}$ Para estudos mais aprofundados com relação à interatividade no jornalismo online ver MIELNICZUK (2001).
} 
jornal é um dispositivo produtor de sentido: a atualidade". Conseqüentemente, o link passa de uma característica hipertextual a um fator de narratividade da hipertextualidade jornalística".

A elaboração e seleção dos links a serem dispostos na página eletrônica não elenca critérios arbitrários, ao passo em que a construção discursiva da realidade por parte do jornal, a qual defende, interpretativamente, determinados valores, necessita de outros textos, tais como aqueles observados no jornal impresso. Estes têm a função de, a partir dos mesmos referentes, determinar os sentidos circulantes na notícia que destaca a interpretação do fato. Como referido acima, o hipertexto possibilita ao interlocutor acesso a inúmeras informações e construções discursivas que, localizadas em uma mesma estrutura hipertextual, procuram observar os acontecimentos de diferentes maneiras, as quais formuladas a partir de pressuposições acerca do interlocutor. Daí os links serem considerados acessos minuciosamente elaborados (MIELNICZUK \& PALACIOS: 2001) com a função de auxiliar na construção da realidade interpretada, delimitando-a a partir dos referentes elencados pela notícia de caráter informativo e interpretativo. Logo, o link como elemento textual no hipertexto jornalístico fundamenta-se em três princípios:

1) Fator de transitoriedade entre os interlocutores;

2) Construção discursiva entre conhecimentos de mundo do interlocutor e do jornal, em um processo de retroalimentação permanente e

3) Ilimitabilidade do hipertexto jornalístico, pois as possibilidades de busca por outros discursos interpretativos são pautadas por elementos que fortificam a realidade construída pelo jornal e suas notícias, o que remete ao conceito de descentralidade ou mobilidade dos centros (LÉVY: 1999).

A notícia hipertextual promove a reconstrução de personagens e elementos, já que, seguindo dos princípios da metamorfose, da heterogeneidade, da multiplicidade e encaixe das escalas, da exterioridade, da topologia e da mobilidade dos centros (LÉVY: 1999), a plasticidade das verdades discursivas torna-se mais frágil na medida em que o universo telemático é explorado. A constante construção e renegociação dos sentidos norteiam os hipertextos. A busca permanente por outras informações que divergem daquelas apresentadas 
sugerem o caráter da exterioridade, já que a rede não tem uma unidade orgânica, já que seu conteúdo depende do movimento informativo. Este atua de acordo com a proximidade ou continuidade de sentidos, processo que caracteriza a topologia. A mobilidade dos centros dáse por meio de espécies de palavras-chave, que sinalizam a busca do interlocutor e que promoverão novas incursões por rizomas, nos quais serão eleitos outros elementos semânticos relevantes. No que diz respeito à notícia, lê-se o que quiser. Busca-se conhecimento por meio do ato investigativo.

Notam-se transformações a respeito da tarefa atual do jornalista que considera e faz uso de novas abordagens investigativas oriundas dos meandros telemáticos. Assim, em conjunto com a descrição oferecida pelo escritor argelino, o jornalista que, direta ou indiretamente, envolve-se com as notícias digitais, preocupa-se também com a disposição das informações, dando importância ao design de um texto. Desta forma, a relevância de um hipertexto noticioso não reside somente em seu aprofundamento interpretativo, mas também em sua estética, atualmente disseminada devido aos avanços obtidos no desenvolvimento e construção de sítios (STORRER: 2002). Um texto noticioso passa, portanto, de um produto investigativo solitário a uma constelação informativa construída de modo a seduzir o interlocutor a partir de suas diretrizes semióticas. Entretanto, a função primordial do jornalista é estabelecer pontes entre o real e a interpretação deste, atuando como mediador. É um vaso comunicador:

Logo, a função do jornalista será transformada radicalmente, pois deverá encaminhar-se no sentido da organização e edição de informações e dados já disseminados no corpo social, dandolhes um tratamento interpretativo, contextual e de significação. Neste último caso, acredita-se que os progressos contínuos na área de multimídia estão a exigir deste profissional o conhecimento adequado de códigos e linguagens que permitam o tratamento dos dados e informações coletados (FERES, 2001, p. 87).

Vale a utilidade e a relevância da notícia. Assim, é crucial criar mecanismos de personalização, delimitando o caráter informativo da rede. Assim, o profissional vê-se forçado a contextualizá-la ainda mais em um esquema trialético (MEDINA \& GRECO: 1994), qualificando o conteúdo do jornal. Isso pode evitar que o interlocutor recepcione o texto de maneira duvidosa, dado o caráter interativo promovido pela telemática. 
No que diz respeito aos links hipertextuais, a tarefa é construir um sítio de maneira coerente, de modo que promova o encaixe semântico não-sequencial, estimulando a criatividade do interlocutor.

Na medida em que os cibernautas selecionam uma seção sobre determinado assunto, devem estar aptos a navegar livremente pelos diferentes tópicos e pela mídia como um todo. A tarefa do publisher, portanto, consiste em apontar para a maximização da habilidade do usuário em perseguir associações individualizadas, de forma que consiga procurar um detalhe sobre um tópico ou até mesmo ir ao encontro de um capricho da imaginação. Apesar de o publisher poder impor uma estrutura de informação, o navegante deveria estar apto também para reconstruí-la e apresentá-la em uma variedade de contextos. Uma publicação hipermídia ideal permitiria ao usuário pular com facilidade de um assunto para outro e de um [sic] mídia para outro. O potencial significativo para as experiências ricas na Internet demanda sistemas de publicação acima de tudo flexíveis (FERES, 2001, p. 91). ${ }^{23}$

Esta figura, portanto, deve salientar não somente o conteúdo, mas também métodos e ferramentas. Tecnicamente, a construção de um sítio prevê como os dados serão dispostos e, conseqüentemente, utilizados e interpretados pelo interlocutor.

O hipertexto jornalístico admite, então, a possibilidade de reforma concernente à notícia jornalística e, conseqüentemente, do texto jornalístico. A existência dos links preconiza uma construção da realidade divergente daquela existente no jornalismo impresso, fazendo que o caráter retórico e argumentativo dos elementos externos ao hipertexto intensifique-se. A partir disso, é possível afirmar que o link hipertextual, se observado de maneira intercultural entre textos jornalísticos provenientes de culturas divergentes, pode trazer grandes contribuições ao estudo dos fatores de textualidade ambientados eletronicamente, como a coerência, bem como à pesquisa de aspectos noticiosos existentes no webjornalismo.

\footnotetext{
${ }^{23}$ Uma discussão acerca do termo publisher é feita por CORRÊA, Thomas Souto. O verdadeiro significado da palavra publisher. Disponível em: http://cursoabril.abril.com.br/coluna/materia_77485.shtml. Acesso em: 01/11/2006.
} 


\section{Capítulo 2. Metodologia}

O presente capítulo trata das questões metodológicas e analíticas aplicadas neste trabalho. Assim, descreve o processo de coleta dos textos jornalísticos, bem como o processo de análise dos mesmos. Estes estágios serão assim contemplados de forma a atender aos propósitos da pesquisa: demonstrar os links como operadores de coerência no hipertexto jornalístico e, a partir disso, observar diferenciações no tratamento do link em dois jornais provenientes de culturas distintas.

Como se depreende do capítulo dedicado ao arcabouço teórico, o texto é um construto de natureza estrutural, semântica, textual e cognitiva, portanto, um objeto multifacetado. A coerência textual é a atribuição de significados ao texto tanto de maneira crescente quanto decrescente, o que reforça a idéia de complexidade apresentada quando da análise de textos. No que tange ao hipertexto, trata-se de um produto sócio-cognitivo fragmentado, mas que integra suas estruturas de modo a estabelecer uma continuidade de sentidos, mesmo que tecnicamente não-linear. No que diz respeito à prática jornalística, afirmou-se que o jornalista transcendeu a condição de relator da contemporaneidade e necessita dominar técnicas de apresentação de conteúdos. Estas instâncias combinam-se de modo a oferecer ao interlocutor episódios fragmentados de um mesmo evento, elencados por meio de diversos referentes angulados a partir de uma mesma linha opinativa. Desta feita, nota-se que os empreendimentos em textos lineares e impressos podem ser aplicados em hipertextos, mas não sem antes considerar suas respectivas características. Observou-se que os hipertextos são representados por nós e links, apresentando textos que são lineares, mas constantemente entrecruzados por sugestões de leitura que demonstram ao interlocutor o que é crucial para a compreensão de um determinado texto noticioso.

Esta pesquisa procura demonstrar como estes links perfazem uma continuidade de sentidos em textos noticiosos não-lineares extraídos de um jornal brasileiro e outro alemão. Assim, de acordo com a sugestão de uma coerência hipertextual, procura-se demonstrar como isso se dá em hipertextos noticiosos provindos de culturas diferentes, o que pode propiciar resultados ainda mais concretos não somente no que diz respeito ao hipertexto noticioso, mas 
também à prática jornalística com relação às inovações tecnológicas concernentes à produção de textos noticiosos.

Os procedimentos empregados para os estágios de análise deste corpus são os seguintes:

- Busca de subsídios bibliográficos sobre os pressupostos acerca da coerência textual, hipertexto, links, jornalismo impresso, webjornalismo e a diferença entre ambos;

- Elaboração do arcabouço teórico referente aos cinco âmbitos que permeiam esta pesquisa;

- Seleção de textos para a formação do corpus, constituído de notícias em alemão e em português;

- Análise do corpus e avaliação dos resultados obtidos à luz do marco teórico estabelecido na pesquisa;

- Formalização dos resultados;

\subsection{Do corpus}

Foram escolhidos dois jornais, de onde foram retirados os textos a serem aqui analisados. Em uma pesquisa empreendida em nível de Iniciação Científica, ocorrida entre os anos de 2002 e 2004, elaborou-se uma pesquisa piloto, na qual foram confrontados os estudos de quatro jornais: os brasileiros Folha de S. Paulo e Jornal da Tarde, e os alemães Frankfurter Allgemeine Zeitung e Die Zeit. O critério de escolha baseou-se, no caso brasileiro, nas divergências empresariais, já que a Folha de S. Paulo pertence ao grupo Abril, ao passo em que o Jornal da Tarde faz parte do grupo O Estado de S. Paulo, concorrente direto do primeiro conglomerado. 
Assim procedendo, esperava-se que as diferenciações editoriais encontradas na comparação entre os dois jornais brasileiros se assemelhassem contrapondo-os às características observadas entre os jornais alemães. O objetivo era verificar o critério editorial e a seleção de notícias. O segundo critério considerado foi a análise textual, ou seja, caso as mesmas notícias fossem observadas nos grupos, a pesquisa se concentraria na análise das possíveis incompatibilidades editoriais no corpo textual. Chegou-se, portanto, aos jornais Folha de S. Paulo e Frankfurter Allgemeine Zeitung.

Desta feita, alterações no corpus durante a pesquisa foram necessárias. Dado o atraso concernente à chegada dos jornais alemães ao Brasil, estipulado em aproximadamente uma semana, o trabalho comparativo tornou-se imprevisível. Optou-se, portanto, por uma nova análise piloto, mas ambientada no espaço virtual. Assim, era possível observar, instantaneamente, se o mesmo fato era veiculado por ambos os jornais, eliminando-se os problemas de atraso. Um breve trabalho comparativo foi empreendido de forma a se observar as mesmas divergências encontradas nas versões impressas, assegurando-se, portanto, a funcionalidade da pesquisa. Para isso, promoveu-se uma incursão teórica que, em parte, foi aqui utilizada e detectou-se que as versões digitais, no corpus analisado, apresentam diferenças semelhantes às observadas nas edições impressas, sustentando e justificando as mudanças efetuadas.

Estes esforços resultaram na formação do corpus aqui utilizado. O mesmo foi elaborado a partir de dois sítios jornalísticos, o brasileiro Folha Online (FO) e o alemão Frankfurter Allgemeine Zeitung. NET (FN). Como acima colocado, a escolha destes dois jornais foi baseada em pesquisas anteriores que primaram pela procura de semelhanças referentes à linha editorial e à seleção de notícias. Ambos mostraram-se similares no que diz respeito a estes critérios, mas por outro lado, verificou-se que os temas e estruturas que construíam o texto noticioso eram ora divergentes ora semelhantes, urgindo estudos mais aprofundados. Assim, optou-se pela continuidade de uso destes jornais, já que as discussões lingüístico-textuais poderiam ser ampliadas.

Foram recolhidos dez hipertextos noticiosos da FO e mais dez do FN no período de 13 a 27 de janeiro de 2006. Apenas dois foram coletados no dia 04 de dezembro de 2006, em razão de problemas técnicos. Os textos online foram recolhidos em pares e selecionados de acordo com os seguintes critérios: 
- Os hipertextos noticiosos selecionados deveriam tratar de temas de alcance global e condicionados, portanto, ao excerto da edição online destinado aos fatos do mundo, representados nos dois jornais na maioria por temas políticos. Assim, esperava-se que interferências culturais, refletidas na construção do texto, se intensificassem quando da veiculação de acontecimentos relativos a problemáticas de alcance mundial;

- A partir do título ou do selo ${ }^{24}$, observava-se se o hipertexto noticioso tratava do mesmo fato. Em caso afirmativo, selecionava-se o texto, a fim de integrá-lo ao corpus. Independentemente de uma similaridade integral, fundamental era avaliar se hipertextos noticiosos tratavam do mesmo tema. Isso é possível devido à construção dos portais, que são permeados por links elaborados a partir do título, quando não refletem, integralmente, estes links;

- A atualidade das notícias, visto que há acúmulo de hipernotícias e revisão constante dos fatos. Logo, optou-se por escolher o maior número de textos noticiosos em um curto espaço de tempo, evitando que os conteúdos fossem perdidos devido a sua retirada pelos jornais ou, até mesmo, que fossem alteradas;

- A data de veiculação dos hipertextos noticiosos deveria ser a mesma, a fim de se analisar o texto construído a partir da mesma matéria prima, sendo possível, portanto, uma comparação mais fiel e, consequentemente, sem que informações díspares fossem encontradas em um texto, mas não em outro.

Em estudos germinais, optou-se pela transcrição do hipertexto, formatando-o como um texto normal, fazendo-se referência somente ao endereço eletrônico no qual se encontrava o hipertexto noticioso. No entanto, este perde suas características estéticas, fundamentais para o estabelecimento da coerência em ambiente virtual, alterando-se para um texto linear, mesmo

\footnotetext{
${ }^{24} \mathrm{O}$ conceito de selo foi esclarecido pelo Prof. Dr. José Luís Proença quando da qualificação desta pesquisa em 13/04/2007. Trata-se de uma etiqueta dada a hipertextos noticiosos oriundos de um fato amplamente repercutido pelo jornal. Antecedente à proposição global, contribui para a continuidade de sentidos no hipertexto noticioso.
} 
considerando-se os links. Nesta pesquisa, a tela na qual está localizada o hipertexto será incorporada ao texto, de forma a mostrar como o hipertexto noticioso foi veiculado, bem como será disponibilizado o endereço eletrônico para que os possíveis interlocutores deste trabalho tenham acesso às notícias analisadas.

\subsection{Procedimento de Análise}

A primeira questão enfrentada nesta pesquisa diz respeito às convergências e divergências relacionadas ao texto impresso e ao hipertexto. Assim, indagou-se se era possível aplicar reflexões empreendidas em textos impressos em hipertextos, especificamente no que diz respeito à coerência textual e aos processos de referenciação no texto. Baseando-se nos apontamentos de Koch $(2003,2004$, s/d), viu-se que o hipertexto noticioso é uma atividade lingüística multisemiótica, ou seja, que agrega diferentes mídias, e suportada em um contexto virtual. Desta maneira, é um construto textual e que traz ineditismos por se tratar de uma nova atividade humana (BAKHTIN: 2002). Assim, os processos de construção de sentido no texto podem ser observados no hipertexto se consideradas as devidas circunstâncias, ou seja, se os pressupostos oriundos da lingüística textual forem circunscritos aos apontamentos relativos ao estudo do hipertexto. Recordando que o nó confere ao hipertexto características concomitantes de texto linear e não-linear, sabe-se que este elemento é cercado por links, elemento que faz do nó um texto hiper. Consequentemente, referenciais teóricos correspondentes ao texto impresso atuaram como base de estudo para incursões concernentes ao estudo do hipertexto noticioso. A partir desta problemática teórica adveio a indagação principal desta pesquisa.

Em conjunto com este primeiro desafio, deparou-se com a formação do corpus. Os pressupostos oriundos da lingüística do texto poderiam ser aplicados ao estudo de hipertextos noticiosos. As considerações acerca da prática jornalística online deveriam suportar as mudanças necessárias, de modo a viabilizar a análise de hipertextos noticiosos. Baseando-se em estudos sobre webjornalismo, viu-se que era possível efetuar a análise em um corpus formado por hipertextos noticiosos, já que o jornalismo online é uma prática ambientada na rede mundial de computadores e, além de apresentar as notícias em um suporte inédito e recente, possui características diferenciadas do jornalismo impresso. Como demonstrado no 
aporte teórico, não há um consenso acerca da linguagem do webjornalismo, ou seja, se ela ainda se encontra em fase de transição ou se já é definida como autônoma com relação ao texto jornalístico impresso. Entretanto, os pressupostos oriundos de estudos sobre a prática jornalística aplicam-se indistintamente a ambos os tipos, tanto impresso como virtual. Assim, semelhantemente ao hipertexto, fez-se uso de apontamentos oriundos de pesquisas sobre o texto jornalístico impresso a fim de alicerçá-los aos estudos de jornalismo online.

Assim, em primeira instância, refletiu-se acerca da escolha dos jornais que formariam o presente corpus. Os critérios basearam-se em semelhanças editoriais, de modo que as notícias encontradas virtualmente no sítio da FO eram, em sua maioria, também observadas na página eletrônica do FN.

Após os processos de seleção de notícias e a colagem das mesmas no corpo desta pesquisa, viu-se diante da necessidade de se delimitar a análise do corpus. Em primeira instância, indagou-se acerca da descrição do corpus. Buscou-se a resposta para isso calcandose nos apontamentos referendados em Lage (2001) e Comassetto (2001), os quais sustentam a hipótese de que os títulos das notícias atuam como concentrados semânticos e orientadores de leitura. Já de acordo com van Dijk (2002) e Koch (2003, 2004), o texto configura-se como um produto sócio-cognitivo permeado pelo constante trabalho de busca compreensiva por parte dos interlocutores, direcionado por esquemas de conhecimento ativados após a ressignificação de referentes estrategicamente construídos e ordenados. Portanto, esta descrição será baseada em duas categorias presentes no hipertexto noticioso, ou seja, serão tecidos comentários acerca das construções textuais referentes ao título do hipertexto noticioso, bem como aos textos dos links, objetos de estudo desta pesquisa. Como já referido, títulos e links circunscrevem o texto de modo a apontar ao interlocutor o que é fundamental em sua leitura, elencando referentes que se destituem de uma integralidade. Desta feita, segmentam o hipertexto noticioso, promovendo uma reconstrução textual a partir de cada personagem de um fato, fazendo de uma notícia uma série de textos interpretativos que reforçam os pontos de vista do jornal. Esta segmentação dá-se através de construções minuciosas a fim de atrair a atenção do interlocutor.

Os títulos serão observados conjuntamente aos links, culminando em um esquema hierárquico, partindo-se dos pressupostos colocados na fundamentação teórica. Parte-se da hipótese de que os links promovem uma continuidade de sentidos e, assim, a comparação 
destas ferramentas hipertextuais com os títulos dos hipertextos noticiosos faz-se plausível. Intenta-se o agrupamento que facilite a exposição das desconstruções textuais. [A partir desse procedimento, surgiram várias questões, sendo as principais as seguintes:

- Como é possível discorrer acerca da coerência textual, fenômeno baseado na uniformidade de sentidos, em um texto ambientado virtualmente e que não obedece a uma estrutura linear?

- Como os links são construídos e como promovem a continuidade de sentidos em hipertextos?

- De que maneira os sentidos são incorporados a um hipertexto a partir da existência de links, que destituem o texto de sua característica tradicional?

- Como o webjornalismo faz uso destas ferramentas a partir de uma perspectiva lingüística?

- E como isso se dá em dois jornais presentes na sociedade brasileira e na sociedade alemã?

Assim, os textos foram analisados de acordo com as seguintes diretrizes práticas:

- Apontamentos referentes à construção de sentidos no hipertexto noticioso. Não obstante, observar-se-ão os efeitos de sentidos que estes hipertextos noticiosos podem produzir através de títulos e links, já que se trata de um texto informativo e, concomitantemente, interpretativo. Assim, uma interpretação, no caso, a do sujeito autor desta pesquisa, será destacada e ressalta-se que é uma entre muitas outras possíveis, já que a coerência textual é concretizada de acordo com a busca de sentidos efetivada pelos interlocutores;

- Considerações que tangem aos estudos do hipertexto, visto que se trata de um gênero textual recente e suportado em um contexto inédito. Desta feita, observar se os links promovem a continuidade de sentidos de maneira não-linear; 
- Observação minuciosa da construção destes links, verificando como são elaborados estrategicamente a fim de atender às hipóteses levantadas nesta pesquisa. Neste estágio da análise, serão verificados os processos de estabelecimento e continuidade de sentidos no hipertexto;

- Por fim, análise do comportamento desses links no contexto de um estudo contrastivo, o que pode sugerir divergências nos âmbitos lingüístico e jornalístico.

A análise do corpus será feita também aos pares e de maneira comparativa. Logo, dois hipertextos noticiosos, um em português e um em alemão, terão seus títulos e links comparados a fim de se observar semelhanças e diferenças em suas elaborações. Serão feitas considerações acerca do hipertexto noticioso analisado, o que integrará o excerto de descrição do corpus. Estes links serão copiados em quadros didáticos e colocados lado a lado para que sejam observados mais facilmente. Adiante, serão feitas primeiramente análises em separado e, por fim, haverá um trabalho comparativo. Quando dos resultados, estes apontamentos comparativos serão retomados com o intuito de concluir o estudo. Feito isso, as considerações finais delimitarão somente aspectos que se mostraram relevantes na pesquisa. Assim, o excerto analítico compreenderá:

- A montagem de organogramas em pares compostos pelos títulos dos hipertextos noticiosos e seus respectivos links;

- Análise detida acerca dos processos de construção de sentidos dados entre o título e os links;

- Comparação analítica dos organogramas, a fim de se observar o comportamento dos links em dois jornais diferentes e

- Seleção dos resultados mais relevantes para o objetivo da pesquisa, independentemente se condizentes com ele ou não. Assim, espera-se que a 
análise propicie um esclarecimento acerca do papel dos links no hipertexto noticioso.

\section{Capítulo 3. Análise}

O presente capítulo está baseado não somente nos pressupostos teóricos delineados, mas também na hipótese do trabalho, que é demonstrar como os links promovem a continuidade de sentidos no hipertexto noticioso. Caso isso se confirme, serão observadas as estratégias empregadas pelos jornais no uso desta ferramenta que viabiliza a existência do hipertexto. Não obstante, tem-se em vista analisar o papel deste elo acessível em uma análise contrastiva que colocará frente a frente aspectos jornalísticos referentes a países culturalmente diferentes, no caso, Brasil e Alemanha.

Desta feita, é necessário considerar que o texto é um amálgama de aspectos relacionados a diferentes instâncias comunicativas. Partindo-se de escolhas lexicais e aportando-se em suportes pragmáticos, este produto lingüístico é multifacetado e frente aos trabalhos cognitivos efetuados pelos interlocutores, nota-se que a produção de sentidos não se dá no texto, mas através dele. Este aspecto faz do texto, além de um objeto material, um processo em permanente construção-desconstrução, já que está à deriva e necessita do interlocutor para ser desbravado (LÉVY: 2002). Dentro deste processo, encontra-se também o hipertexto, formado por nós e links, visto que estes últimos também são produtos textuais.

Os resultados relacionados aos dados obtidos a partir dos textos que formam o corpus serão analisados à luz das teorias acerca da lingüística textual, do hipertexto e do webjornalismo já aqui apresentadas. O corpus é formado por textos oriundos da Folha Online e do Frankfurter Allgemeine Zeitung. NET, brasileiro e alemão, respectivamente, elaborados diariamente por estes jornais. São notícias de conteúdo variado e que foram retiradas de cadernos que possibilitassem um estudo contrastivo. Estes cadernos são denominados, no jornal brasileiro, mundo e esporte. No primeiro veiculam-se hipertextos noticiosos relacionados somente a países estrangeiros, já do excerto relacionado aos fatos esportivos, é possível obter informações tanto de âmbito nacional quanto internacional. No jornal alemão, os mesmos critérios foram aplicados, pois em se tratando de um estudo contrastivo, é 
necessário estabelecer diretrizes gerais e iguais para o recolhimento de textos para o corpus. Logo, os cadernos "Ausland" (exterior), abarcado pela aba denominada "Politik" e "Sport", foram selecionados como fonte de hipertextos noticiosos oriundos do FN. 
Os hipertextos noticiosos escolhidos são os seguintes:

\begin{tabular}{|c|c|c|c|}
\hline Folha Online & FAZ.NET & Tradução & Data \\
\hline $\begin{array}{l}\text { T1. Bachelet vence e será a primeira mulher a } \\
\text { governar o Chile - }\end{array}$ & $\begin{array}{l}\text { T1.1. Sozialistin Bachelet erste Präsidentin } \\
\text { Chiles }\end{array}$ & $\begin{array}{l}\text { T1.2. Socialista Bachelet é a primeira } \\
\text { presidente do Chile }\end{array}$ & $16 / 1 / 2006$ \\
\hline $\begin{array}{l}\text { T2. Ataque suicida no Afeganistão deixa } 20 \\
\text { mortos - }\end{array}$ & $\begin{array}{l}\text { T2.1. Kandahar Selbstmordattentäter in } \\
\text { Afghanistan töten } 24 \text { Menschen }\end{array}$ & $\begin{array}{l}\text { T2.2. Homem bomba mata } 24 \text { no } \\
\text { Afeganistão }\end{array}$ & $20 / 1 / 2006$ \\
\hline $\begin{array}{l}\text { T3. Chávez comemora vitória com ampla } \\
\text { vantagem - }\end{array}$ & $\begin{array}{l}\text { T3.1. Präsidentwahl in Venezuela. Klarer Sieg } \\
\text { für Chavez }\end{array}$ & T3.2.Vitória clara para Chávez & $4 / 12 / 2006$ \\
\hline $\begin{array}{l}\text { T4. Ex-presidente alemão Johannes Rau morre } \\
\text { aos } 75 \text { em Berlim - }\end{array}$ & $\begin{array}{l}\text { T4.1. Johannes Rau ist tot. Er wollte } \\
\text { "versöhnen, nicht spalten" }\end{array}$ & $\begin{array}{l}\text { T4.2. Morre Johannes Rau. Ele queria } \\
\text { "conciliar, não separar" }\end{array}$ & $4 / 12 / 2006$ \\
\hline $\begin{array}{l}\text { T5. Grupo extremista Hamas vence eleições } \\
\text { legislativas na Palestina - }\end{array}$ & T5.1. Fatah-Regierung tritt zurück & $\begin{array}{c}\text { T5.2. O governo Fatah sai de cena na } \\
\text { Palestina }\end{array}$ & $26 / 1 / 2006$ \\
\hline $\begin{array}{l}\text { T6. Juiz do ex-ditador do Iraque apresenta carta } \\
\text { de renúncia - }\end{array}$ & $\begin{array}{l}\text { T6.1. Irak Vorsitzender Richter im Saddam- } \\
\text { Prozess zurücktreten }\end{array}$ & $\begin{array}{l}\text { T6.2. Juiz responsável no processo contra } \\
\text { Saddam renuncia }\end{array}$ & $26 / 1 / 2006$ \\
\hline $\begin{array}{l}\text { T7. Líderes se reúnem em Londres para discutir } \\
\text { crise com Irã - }\end{array}$ & $\begin{array}{l}\text { T7.1. IAEA-Chef Baradei schlie } \beta \text { t Gewalt gegen } \\
\text { Iran nicht aus }\end{array}$ & $\begin{array}{l}\text { T7.2. Chefe da AIEA, Baradei não } \\
\text { descarta violência contra Irã }\end{array}$ & $14 / 1 / 2006$ \\
\hline $\begin{array}{l}\text { T8. Ministro de Israel acusa Síria e Irã de } \\
\text { financiar atentados - }\end{array}$ & $\begin{array}{l}\text { T8.1. Mofaz: Anschlag war das Werk Irans und } \\
\text { Syriens }\end{array}$ & $\begin{array}{l}\text { T8.2. Mofaz: Atentado foi obra da Síria e } \\
\text { Irã }\end{array}$ & $16 / 1 / 2006$ \\
\hline $\begin{array}{l}\text { T9. Resultados apontam vitória do Hamas em } \\
\text { eleições palestinas - }\end{array}$ & T9.1. Schiiten verfehlen einfache Mehrheit & $\begin{array}{c}\text { T9.2. Xiitas não conseguem maioria } \\
\text { absoluta }\end{array}$ & $22 / 1 / 2006$ \\
\hline $\begin{array}{l}\text { T10. Bush diz que há obrigação de impedir armas } \\
\text { nucleares no Irã - }\end{array}$ & T10.1. Bush mit Zeit und Lobe für Merkel & $\begin{array}{l}\text { T10.2. Bush com tempo e elogio para } \\
\text { Merkel }\end{array}$ & $13 / 1 / 2006$ \\
\hline
\end{tabular}




\subsection{Análise de T1, T1.1 e T1.2}

O primeiro grupo do corpus refere-se às eleições presidenciais do Chile vencidas por Michele Bachelet. Escolheu-se tal texto em razão da proximidade deste país com o Brasil, já que ambos estão localizados no continente sul-americano. Em segunda instância, a nova presidente chilena é socialista, o que evoca conceituações diferenciadas, dadas as histórias de Brasil e Alemanha. Um terceiro critério concerne ao tema, política, que sempre suscita discussões e posicionamentos divergentes.

O T1, referente ao hipertexto da FO, dá início ao hipertexto noticioso com o seguinte título: "Bachelet vence e será a $1^{\text {a }}$ mulher a governar o Chile". Assim, o jornal identifica os personagens da notícia, ou seja, estabelece sentidos entre as duas palavras, de modo a intercalá-las com "1 mulher". Assim, esta intermediação tem a função de construir a coerência, de modo a informar ao interlocutor que o governo chileno será presidido por uma mulher a partir de então. A estratégia do jornal está exatamente na concisão e na figuração inicial de impulsionadores de sentido que procuram delimitar o escopo semântico do hipertexto jornalístico. Assim, "Bachelet" é uma informação nova que se apoiará em um suporte relacionado ao país latino-americano. Não obstante, "1 $1^{\mathrm{a}}$ mulher" também terá seu sentido construído a partir do que já é conhecido pelo interlocutor.

Ao se observar os links, notou-se que não havia nada relacionado ao acontecimento interpretado pelo jornal brasileiro. Logo abaixo do nó informativo, notam-se quatro elos links perfilados em uma seção denominada "destaques": "Arábia Saudita: tumulto mata $50 \mathrm{em}$ peregrinação a Meca"; "Saúde: novas tecnologias aumentam estresse, diz ONG"; "Angelina Jolie está grávida de Brad Pitt, diz assessora" e "On-line: diário musical de Mozart vai para a Internet". Apreende-se que nenhum destes links relacionam-se diretamente com a eleição da chilena, ao passo em que são elementos de subsistência do hipertexto. Logo, indaga-se se este hipertexto noticioso analisado é um hipertexto, já que não dirige o interlocutor a outros sítios eletrônicos de modo a configurar uma uniformidade de sentidos a ser construída no link. As notícias linkadas não estão relacionadas com o nó informativo analisado, mas sugerem ao interlocutor a permanência no sítio jornalístico da $F O$. Logo, não há continuidade de sentidos neste hipertexto, visto que, se o interlocutor clicar sobre um destes links, os hipertextos noticiosos não se encontrarão em uma continuidade de sentidos. Assim, o espaço que seria 
preenchido com links referentes ao hipertexto noticioso foi utilizado para dar relevância não ao hipertexto lido, mas ao papel informativo do jornal. Desta feita, é possível realizar duas interpretações acerca da ausência de links para o hipertexto noticioso analisado. A primeira reside no fato de o acontecimento não provocar interesse o suficiente por parte da FO. Já a segunda diz respeito à estratégia do jornal em construir um texto baseado em um determinado perfil de interlocutor, o qual deseja não obter mais informações acerca da eleição da nova presidente chilena, mas sim, de outros assuntos e variados. Esta última hipótese passa a ser a mais plausível, pois o jornal não se arriscaria a perder seu interlocutor pelo simples fato de não ter, por exemplo, segmentado o hipertexto noticioso, reunido os aspectos principais do acontecimento em um primeiro hipertexto e transformado os fatos periféricos em links, criando um hipertexto noticioso coerente. Não obstante, a construção de links, apesar de não contribuírem para a uniformidade de sentidos no hipertexto, são estrategicamente formulados a partir da disposição de hipertextos noticiosos oriundos de diferentes temáticas, indo de política, passando por assuntos supérfluos e chegando até o excerto cultural. Assim, a partir de um fato considerado importante pela FO, este jornal atrai o interlocutor a partir deste chamariz e procura mantê-lo usando da estratégia de configuração de notícias tematicamente variadas.

Analisando-se o hipertexto noticioso referente ao FN, nota-se que o título "Socialista Bachelet é a primeira presidente do Chile" foi construído com base na ativação de conhecimentos prévios relacionados não somente ao nome da nova presidente chilena e ao país, mas também ao seu posicionamento político, ou seja, ela é socialista. De início, vê-se que o FN insere no título o posicionamento político de um novo líder. Nota-se que é o primeiro elemento da proposição, procurando ativar no momento da interação com o título os sentidos em relação à informação "socialista". É uma estratégia textual utilizada para atrair a atenção do interlocutor não somente por estar no âmbito político; o acontecimento é interpretado sob a ótica de um fato histórico e relativo a uma corrente que ainda exerce grande influência em muitos países do mundo. Assim, o FN aproveita-se de influências culturais européias para dirigir o interlocutor aos fatos ocorridos na América Latina, comunicando ao interlocutor que esta corrente política ainda é vitoriosa em outros continentes. Como fatos relevantes, a proposição textual ainda contém "primeira" e "presidente", que propõem ao interlocutor sentidos que serão estabelecidos em conjunto com o termo "socialista". 
Com relação aos links construídos pelo FN, vê se que o link L1 faz uso de um referente que também surge no título. Assim, o jornal alemão evoca uma personagem do hipertexto noticioso para a construção de L1 e, com isso, procura dar um novo tratamento a este referente. Observando-se atentamente o título, Bachelet é caracterizada como um socialista que será a primeira mulher a presidir o Chile. No entanto, a elaboração deste link promove a reconstrução do objeto do texto, já que aqui ela é celebrada como uma santa. É uma estratégia textual que visa a construção e, com isso, a reconstrução dos efeitos de sentido no hipertexto noticioso. Nota-se que, como estratégia do jornal, o link é uma ferramenta que, além de promover uma continuidade de sentidos, reconstrói, por meio de enquadramentos diferenciados, determinados elementos do texto. É uma recategorização da presidente recém eleita do Chile. Em termos jornalísticos, pode-se afirmar que um hipertexto noticioso concomitante ao acontecimento principal e que comunica fatos inéditos ao interlocutor, de modo a ampliar o espectro informativo daquele hipertexto noticioso. Assim, por critérios de relevância, o jornal alemão elaborou o L1 de modo a perfazer uma continuidade de sentidos, elegendo uma das personagens da notícia como a principal da proposição. Além de ser socialista e a primeira presidente da história do Chile, é interpretada também como uma santa.

O L2 diz respeito a uma construção textual semelhante ao título, ou seja, não apresenta diferenciações com relação à construção de sentidos. No entanto, ele apresenta um diferencial concernente à característica da multimodalidade observada na rede mundial de computadores e, especificamente, no hipertexto. A utilização do hipertexto com um meio multisemiótico torna-se também uma ferramenta estratégica quando se observam hipertextos noticiosos. Assim, o jornal alemão aproveita a estrutura oferecida pelas tecnologias do hipertexto noticioso e procura ampliar não o aspecto informativo por meio de recategorizações dos elementos do texto, mas sim, através da utilização de uma outra mídia, no caso, um vídeo. É uma estratégia que visa a aproximação com a linguagem televisiva e, com isso, atinge dois tipos de interlocutores, ou seja, aquele que prefere textos escritos e aquele que estima imagens. Com relação ao L3, observa-se não somente um processo de reconstrução dos sentidos circulantes no nó informativo, mas também o oferecimento de uma informação não existente no hipertexto noticioso. A partir de um referente exibido no título, no caso, eleição, o FN promove a constante ressignificação semântico-textual, dirigindo o interlocutor da interpretação da vitória da candidata nas eleições chilenas à disputa entre os candidatos no segundo turno. Assim, a circunscrição informativo-interpretativa oferecida pelo FN extrapola o fato da vitória e aporta no processo de escolha por parte dos interlocutores. Trata-se de um 
elo acessível que promove uma continuidade de sentidos e, concomitantemente, indica ao interlocutor um hipertexto noticioso que comunica os antecedentes da vitória. É um fato histórico que tem como finalidade demonstrar ao interlocutor como se deu a vitória da chilena nas eleições presidenciais.

Um trabalho comparativo entre os hipertextos noticiosos oriundos de dois jornais não se mostra viável, já que o jornal brasileiro não fez uso de links relacionados ao hipertexto noticioso. No entanto, podem-se observar semelhanças e divergências no que tange às estratégias jornalísticas de construção dos hipertextos noticiosos. A $F O$ optou por não ampliar o espectro interpretativo do hipertexto noticioso e, consequentemente, elencou quatro links que orientam o interlocutor da existência de hipertextos noticiosos de temática variada. Por meio de uma notícia relacionada à política internacional, procura atrair seus interlocutores a outros hipertextos noticiosos, agregando, portanto, outros em um mesmo espaço. Valeu-se da possibilidade de não uniformizar os sentidos entre links e nós, de forma a não construir links relacionados àquele hipertexto noticioso, mas sim, ao possível interesse do interlocutor. $\mathrm{O}$ contrário foi observado no hipertexto noticioso do FN, que fez uso da estrutura hipertextual, compreendida por nós e links, listou três links que, por meio de reconstruções de sentidos, ampliou as categorias informativas do hipertexto noticioso e, consequentemente, com esse aparato, sustentou opiniões e argumentos referentes à sua linha editorial, baseando-se em uma papel extensivo promovido pelo link.

\subsection{Análise de T2, T2.1 e T2.2}

O segundo grupo refere-se ao ataque de homens-bomba no Afeganistão, o que deixou, ao menos, vinte pessoas mortas. Sabe-se que estes conflitos originam-se da invasão americana ocorrida no ano de 2001 sob o argumento da captura de Osama Bin Laden, um dos acusados pelos atentados ao World Trade Center no mesmo ano em Nova York. Em decorrência das discussões acerca da funcionalidade da ocupação do país localizado no Oriente Médio, bem como acerca de sua viabilidade, posicionamentos políticos divergentes vieram à tona, não somente em aspectos de estado, mas também relacionados a determinadas organizações, como a Organização das Nações Unidas e a União Européia. Tais diferenciações também se relacionam à política bélica que fortalece determinados países, dando margem a práticas 
unilaterais e isoladas. Baseando-se nesta exposição, esperam-se observar os links como fatores de coerência, ou seja, que tenham sido construídos com base no nó informativo, a fim de dar continuidade ao hipertexto noticioso.

O título "Ataque suicida no Afeganistão deixa 20 mortos", aparentemente, não apresenta particularidades a respeito da construção de sentidos neste hipertexto jornalístico. No entanto, como afirmou Comassetto (2001), o título é uma proposição global no texto interpretativo e procura abrigar elementos que ativem conhecimentos por meio de esquemas cognitivos. Notase, portanto, que a apresentação da notícia online traz uma interpretação concisa do fato, comunicando ao interlocutor o acontecimento quase que brutalmente. No entanto, dado que o texto é um produto sócio-cognitivo e que, consequentemente, apresenta graus de subjetividade, o título é um construto estratégico do jornal a fim de atrair o interlocutor para o texto. A construção de sentidos no título é de fundamental importância para que, ao mesmo tempo em que seduz, não informe ao interlocutor acerca do acontecimento como um todo perspectivado. Nesta proposição inicial, observa-se que o fato, a sua localidade e conseqüências foram esmiuçados, antecipando-se parcialmente o lead do hipertexto noticioso. Reflexo do fator tempo, o título procura adiar as principais informações do fato encurtando, portanto, o nó.

Com relação aos links, nota-se que somente um foi disponibilizado pela FO, circunscrito a uma categoria denominada "Especial". Neste caso, trata-se de um link que dirige o interlocutor a um portal de hipertextos noticiosos referentes aos acontecimentos no Afeganistão. Apreende-se que o jornal brasileiro pretende, após a leitura do nó informativo, suscitar o desejo de se dirigir a um sítio eletrônico somente com notícias tematicamente semelhantes àquela lida. De acordo com o título da seção, este funciona como um alerta de que a FO organizou e disponibilizou uma seção de notícias que despertarão no interlocutor a necessidade de interagir com mais textos interpretativos. Ressalta-se que a disponibilização de vários hipertextos noticiosos relacionados a um mesmo fato tem, no escopo das estratégias jornalísticas, fazer com que o interlocutor não migre para um outro jornal e que, por isso, permaneça no sítio. Desta forma, ele interagirá com inúmeros hipertextos noticiosos que foram estrategicamente dispostos a fim de sustentar as opiniões do jornal sob a égide da configuração de um portal. 
No que diz respeito ao T2.1 veiculado pelo FN, o título "Homens bomba matam 24 no Afeganistão" não difere dos pressupostos teóricos acerca desta categoria textual. Assim, esta proposição global procura dar conta de todas as relações textuais a serem desdobradas no decorrer do hipertexto jornalístico, concentrando em sua estrutura o máximo de elementos que procuram ativar conhecimentos prévios no interlocutor. "Homens bomba", "matam" e "Afeganistão" foram escolhidas pelo jornal a fim de não somente atrair a atenção do interlocutor interpretando-lhe sumariamente o acontecimento, mas também com o objetivo de postar a opinião do jornal. Elas atuam como "expressões encapsuladoras de sentido" (KOCH: s/d), já que estão agregadas no mesmo campo semântico. É interessante notar que "homens bomba" tem sido amplamente utilizado no contexto do Oriente Médio e estão sempre associados a radicais muçulmanos. Apreende-se que é uma proposição que visa não somente o acionamento de conhecimentos prévios, mas também a delimitação do campo semântico que limitará as pressuposições do interlocutor, além de dirigi-las para um determinado esquema cognitivo.

Concernente aos links, nota-se de antemão que o FN listou três deles e todos relacionados ao nó informativo. Pode-se afirmar, portanto, que se trata de um hipertexto jornalístico, já que há uniformidade de sentidos entre nó e links. Concentrando-se no L1, vê-se que a construção deste elo acessível diz respeito a um hipertexto noticioso concernente ao fato noticiado, mas não subsidiado a ele, ou seja, não se refere ao atentado promovido pelos terroristas. É um elo acessível que promove uma continuidade de sentidos, pois se tratam de assuntos relacionados, mas a perspectiva dada pelo jornal alemão FN concerne a um outro aspecto dos acontecimentos. É um link que é construído de modo a amparar a produção de um hipertexto noticioso, ancorando-o textualmente em um outro. Daí ressalta-se a importância do título, já que "Afeganistão" ativa conhecimentos cognitivos referentes ao período no qual se encontra o país de maioria islâmica. O título, ao mesmo tempo em que delimita as pressuposições dos interlocutores, permite ao jornal intercalar hipertextos noticiosos que dizem respeito a um tema amplo, como aqui se vê. Assim, o L1 contribui para a uniformidade de sentidos, mas não retoma referentes e, por isso, é aqui considerado como um link que está relacionado ao nó informativo. É um caso típico de coerência implícita (KOCH: 2004).

Já o L2 repete a estratégia do FN, já que elenca como link "Paquistão: Americanos caçam Zawahiri”. Assim como no L1, é uma relação implícita, ou seja, nenhum referente foi claramente retomado, mas sim, de maneira implícita. O implícito: já não basta os americanos 
estarem presentes em território afegão, partem para a caçada de um terrorista. Adiante, se efetuada uma comparação com o L1, trata-se de uma continuidade de sentidos entre links. Construído de acordo com os elementos "Paquistão", pais asiático e que ganhou destaque na mídia após os conflitos com a Índia pela disputa da Caxemira, o link suscita indagações também devido ao nome "Zawahiri”, que é o ideólogo da Al-Qaeda. Nota-se a construção de sentidos referente ao título, especificamente à palavra "Afeganistão" e ao L2. Este link acaba por incorporar um país entre os hóspedes de terroristas, perfilando os sentidos de "homem bomba", "matar" e "Afeganistão". Estrategicamente, o FN inclui o Paquistão como um abrigo para terroristas da organização de Osama Bin Laden.

No que concerne ao L3, último link elencado pelo jornal FN, nota-se que se trata de um hipertexto noticioso paralelo ao analisado. Diferentemente do L2 que, a partir do acionamento de esquemas cognitivos relacionados ao terrorismo insere neste contexto o Paquistão, neste link exalta-se novamente um atentado com homem bomba. Entretanto, é notável que há tratamentos divergentes quando da construção do nó. Este interpretou ao interlocutor um acontecimento relacionado a um país sob invasão norte-americana e que tem observado episódios constantes de violência. O L3 também comunica fato relacionado ao nó, mas traz uma nova perspectiva a ele, ampliando o leque de observações a respeito de um mesmo acontecimento. Agora, o FN concentrou-se no alcance destes atos terroristas que também almejam autoridades e não somente alvos civis. Fundamental, portanto, é notar o espectro de temas construídos pelo jornal e, mais ainda, ampliados a partir de um elemento textual que constituirá não somente o nó, mas também toda a arquitetura hipertextual.

A FO diverge do FN. A construção do link no jornal brasileiro dá-se por meio de um chamariz que indica uma seção especial, ou seja, que difere das outras, por agregar hipertextos noticiosos relacionados ao mesmo assunto. A construção deste portal integrado a um nó informativo poderia fazer parte da primeira página eletrônica do jornal. No entanto, o alvo desta pesquisa é analisar a construção de sentidos no hipertexto jornalístico e, desta maneira, pode-se afirmar que o tema, centralizado no elemento textual "Afeganistão", orienta a produção do hipertexto noticioso. "Leia o que já foi publicado sobre o Afeganistão" é uma proposição global (van DIJK: 2002) que indica um sítio diferenciado dos outros não somente por organizar as informações relacionadas a um acontecimento, mas também por se valer de uma construção textual que procura convencer o interlocutor de que tudo que concerne ao tema já foi publicado pelo jornal FO. Entretanto, nota-se que este jornal, a partir da 
interpretação de um fato mais específico, faz uso do termo "Afeganistão" após o uso do título “Ataque suicida no Afeganistão deixa 20 mortos". É crucial observar a relação de sentidos existente entre título e o L1, o elo acessível solitário elaborado pelo jornal brasileiro. O país localizado no Oriente Médio é proposto como uma terra de terroristas incorporados em homens bomba. O FN aproveita-se das facilidades oferecidas pela tecnologia do hipertexto para inserir na estrutura eletrônica hipertextos noticiosos relacionados ao mesmo acontecimento. Desta feita, elenca três links que noticiam fatos concernentes ao título do hipertexto noticioso veiculado em alemão. Estes três links atualizam, à estratégia da FO, os sentidos construídos no nó informativo, indicando as perspectivas ao interlocutor e corroborando o aspecto comunicativo da linguagem (cf. DINES: 1994). Ao passo que o FN elenca três links que sugerem uma amplitude informativa a partir da interpretação de um acontecimento, ela delimita o as possibilidades de contra-argumentação do interlocutor. É uma estratégia de utilização de determinados elementos que são inseridos no contexto de produção do hipertexto noticioso e que indicam ao interlocutor o alcance da informação. Assim, conclui-se parcialmente que os links, além de recategorizar os elementos do nó hipertextual, ampliam o contexto do hipertexto noticioso, dirigindo o interlocutor a fatos inseridos na mesma temática.

\subsection{Análise de T3, T3.1 e T3.2}

O terceiro conjunto de hipertextos noticiosos trata das eleições parlamentares no Iraque. O país, comandado por muitos anos pelo ex-ditador Saddam Hussein, foi protagonista, na década de 90, em duas guerras: a Guerra do Golfo (1991) e a Guerra do Iraque (2003). Ambas foram comandadas pelos Estados Unidos. Especificamente com relação à última, o argumento yankee era que o ex-ditador iraquiano possuía armas de destruição em massa e que elas poderiam ser usadas contra os americanos. George W. Bush recebeu o apoio dos chefes de estado: Silvio Berlusconi (Itália), José María Aznar (Espanha) e Tony Blair (Reino Unido). Por outro lado, os americanos desrespeitaram uma resolução do Conselho de Segurança da Organização das Nações Unidas (ONU), o qual não aprovou o apelo dos americanos por uma invasão ao país do Oriente Médio. No ano de 2004, George W. Bush disse que a razão de invadir o Iraque baseou-se na perturbação da paz mundial e na ameaça à democracia. Com a ocupação americana, Saddam Hussein foi derrubado e instalou-se um regime de exceção no 
país. Desde então, ações contra a ocupação de soldados americanos e, consequentemente, contra a invasão dos Estados Unidos ao país são freqüentes. Eleições parlamentares foram realizadas e um partido xiita, de inclinação mais extremista, sagrou-se vencedor. O presidente americano George W. Bush cogita retirar as tropas americanas do Iraque o mais breve possível, devido ao alto número de soldados americanos mortos. Protestos ao redor do mundo pedem a liberdade iraquiana, de modo que o povo possa escolher seu sistema de governo sem interferências externas. De acordo com estas considerações, posicionamentos divergentes foram observados com relação ao tema e espera-se que estas diferenciações sejam observadas nos hipertextos noticiosos interpretados pelo jornal brasileiro FO e pelo jornal alemão FN.

Dando início à análise do hipertexto noticioso, o título, qual seja "Aliança xiita vence eleições parlamentares no Iraque", revela uma concisão a partir da concentração dos principais aspectos do fato, o que elegeu personagens no que diz respeito à configuração do acontecimento. Observando-se o L1 "Leia cobertura completa sobre eleições parlamentares no Iraque", nota-se que este jornal faz uso de uma seção especial relativa ao processo eleitoral no país árabe. O jornalista, além de ter empreendido a mesma estratégia quando da construção do título, isto é, ter reutilizado "eleições parlamentares no Iraque" no link, faz uso de uma tática de repetição textual que procura sinalizar a concentração do interlocutor. Novamente, a FO procura organizar um portal de informações que transmita a sensação de informatividade completa ao interlocutor. Entretanto, apesar de que a estratégia textual para a construção do link refira-se a um amplo número de hipertextos noticiosos, a intenção do jornal é sustentar suas opiniões a partir deste chamariz. Desta maneira, é mais interessante elencar um link que desperta a atenção no interlocutor de maneira global, advertindo-o de que este jornal organizou todas os hipertextos noticiosos referentes a um mesmo acontecimento. A construção destes portais por meio de links implica em uma relação de complacência entre jornal e interlocutor advém da evolução histórica do jornal impresso, o qual se mostra à sociedade como porta-voz da verdade (MOSCA: 1993). Esta relação tácita de confiança permite ao jornal variações na elaboração dos links. Assim, ao invés de elencar um link que remeta o interlocutor diretamente a um outro hipertexto noticioso, o jornal optou por um que demonstre ao interlocutor um outro serviço, além daqueles oferecidos pela tecnologia do hipertexto: a de organizar uma série de hipertextos noticiosos a partir de uma seção. Assim, além dos cadernos de praxe de um jornal, como política, mundo, esportes, cultura etc., o jornal cria cadernos especiais e diferenciados que tratem de um determinado acontecimento. Assim, a estratégia do jornal reside neste plus, ou seja, neste serviço extra oferecido ao 
interlocutor. É uma das hipóteses para se explicar o fato de o jornal brasileiro não elencar um link direto, ou seja, que dirija o interlocutor sem interrupções a um outro hipertexto noticioso.

No que diz respeito ao L2, é fundamental notar novamente o aspecto repetitivo deste hipertexto noticioso. "Leia o que já foi publicado sobre as eleições parlamentares no Iraque". Este elo acessível diferencia-se de L1 no que diz respeito ao tratamento dado pelo jornal com relação aos fatos e acontecimentos relativos às eleições parlamentares no Iraque. Em primeira instância, nota-se que um diz respeito a uma cobertura completa e o L2 a tudo o que já foi noticiado acerca do assunto. Apreende-se que o L1 não se refere somente a uma agregação de hipertextos noticiosos referentes ao mesmo fato, mas é tratada de maneira diferenciada pelo jornal. Desta feita, como já colocado, o L1 é um caderno especial, para o qual foram designadas reportagens especiais. No que concerne ao segundo link, o jornal FO procurou agregar os hipertextos noticiosos relacionados ao assunto e tentou chamar a atenção novamente com "eleições parlamentares no Iraque". Vê-se que este hipertexto é constantemente elaborado a partir desta proposição textual. Consequentemente, o jornal procura interpretar ao interlocutor este acontecimento com a estratégia de repetição acerca das eleições parlamentares. Nota-se que estes processos referenciais, partindo-se do pressuposto de que a repetição é um tipo de referenciação (KOCH: 2004), dão-se não somente no nó, mas também nos links, o que sugere uma coerência hipertextual. Estrategicamente, o jornal, após a queda do regime ditatorial de Saddam Hussein, parece tentar convencer de que há uma democracia no Iraque e, com isso, um parlamento formado por políticos de diversas naturezas partidárias. Trata-se de um fato novo no que diz respeito à história dos acontecimentos relativos ao país do Oriente Médio. Assim, a FO elaborou dois links referentes a um mesmo assunto, mas que tratam destes acontecimentos de maneira diferente. Contribuindo para o processo de uniformidade de sentidos, a análise deste hipertexto noticioso mostra que dois links foram elaborados a fim de interpretar ao interlocutor não somente a relevância, mas também o ineditismo deste acontecimento. Daí a necessidade de se repetir "eleições parlamentares no Iraque", bem como de se construir um hipertexto noticioso com dois links que agregam, distribuem e dão mais importância ao fato, ainda de recente conhecimento do público-leitor do jornal.

No que concerne ao hipertexto noticioso interpretado pelo jornal FN, o título "Xiitas não conseguem maioria absoluta" especifica e interpreta o acontecimento ao interlocutor auxiliado pelo selo "Resultado das eleições no Iraque". Assim, o interlocutor tem a possibilidade de ter 
conhecimento acerca do fato tratado pelo hipertexto noticioso. A partir disso, diversos esquemas cognitivos são ativados para que o título do hipertexto noticioso seja alvo de interação e, com isso, todo o conteúdo da notícia. "Xiitas [...]” é um referente que se apóia na proposição anterior e diz respeito à divisão religiosa em território iraquiano entre xiitas ou radicais e sunitas ou moderados. Entende-se que esta separação amplia-se ao campo político, dada a proposição global analisada. Observa-se que a especificidade com que o hipertexto noticioso é produzido possibilita um link que amplie o tema interpretado.

Desta forma, há um único link no jornal alemão. "Especial FAZ.NET: Eleições no Iraque" traduz a necessidade do jornal em demonstrar ao seu público-leitor que o jornal elaborou uma seção especial no que diz respeito às eleições iraquianas. Para isso, construiu um link que não somente indica esses aspectos, mas também faz uso da palavra "especial" para que o interlocutor seja despertado e acesse o caderno eletrônico preparado pelo jornal alemão. O FN procura dirigir o interlocutor a uma seção especialmente preparada para tratar dos assuntos referentes às eleições iraquianas. Trata-se de uma espécie de dossiê, ou seja, de uma compilação de hipertextos noticiosos.

Em um trabalho comparativo, ambos os jornais optaram por elencar links que foram construídos a partir da criação de cadernos especiais eletrônicos. Estes organizam e disponibilizam ao interlocutor todas as notícias hipertextuais relacionadas a um mesmo acontecimento, com reportagens especiais. Ao contrário do L2 no jornal brasileiro, que se mostra como um simples agregador de hipertextos noticiosos, os L1 da FO e do FN referemse a dossiês especiais relativos às eleições iraquianas. É também passível de observação que os links contribuem para uma uniformidade de sentidos nos dois hipertextos noticiosos analisados. No entanto, os três links, dois do jornal brasileiro e um do alemão, dirigem o interlocutor a um caderno especial. Nota-se que, a partir de um referente presente no título do hipertexto noticioso, o qual "eleições parlamentares no Iraque", o jornal brasileiro enfoca a necessidade de interpretar ao interlocutor tal fato inédito e permeia isso por todo o hipertexto noticioso. O mesmo se passa com o FN, mas o jornal alemão faz uso da palavra "especial", o que provavelmente chama a atenção do interlocutor. Apreende-se, portanto, que ambos os jornais utilizam estrategicamente a arquitetura hipertextual para demonstrar ao interlocutor que o assunto é relevante e que, com isso, dossiês foram preparados. Nota-se também que os dois jornais optaram por construir links desta natureza a retomar, com novo tratamento, referentes do título. Isso indica que, nos hipertextos noticiosos analisados, os jornais 
disponibilizam estes links quando há dossiês. O ineditismo do fato faz com que o jornal ofereça ao interlocutor somente um elo acessível que responda pela existência de cadernos especiais. A partir disso, observou-se que a FO optou por elencar um especial e um amálgama de hipertextos noticiosos. Já o FN listou um dossiê.

\subsection{Análise de T4, T4.1 e T4.2}

O quarto grupo de hipertextos noticiosos analisado refere-se à crise nuclear promovida pelo Irã. O tema é polêmico devido ao Tratado de Não-Proliferação de Armas Nucleares, ratificado em 1970. Reconhecido atualmente por 187 países, a integridade do pacto é constantemente verificado por agentes da Agência Internacional de Energia Atômica (AIEA). Com sede em Viena na Áustria, seus profissionais são autorizados a visitar os países que fazem parte do tratado, a fim de verificar se as possibilidades oferecidas pela energia nuclear estão sendo utilizadas para fins bélicos. Após a verificação de que o Iraque estava desrespeitando o acordo, os agentes incumbem-se também de visitar instalações não declaradas pelos países anfitriões. $\mathrm{O}$ atual detentor do cargo máximo da AIEA é o egípcio Mohammed El Baradei. O programa nuclear do Irã é alvo das autoridades da AIEA desde o ano de 2002, e a partir do ano de 2005, o país iniciou a conversão de urânio, fato pelo qual pode sofrer sanções econômicas e diplomáticas. Principalmente os Estados Unidos acusam o país islâmico de desenvolverem armas de destruição em massa. O Conselho de Segurança da ONU, formado por Estados Unidos, China, Rússia, França e Grã-Bretanha, mais a Alemanha, decidirá se haverá punição ao Irã. Principalmente pela participação alemã no processo e pelo desejo de o Brasil por um assento permanente no Conselho de Segurança da ONU, aguardamse tratamentos diferenciados com relação ao tema. Relembrando-se os pressupostos de ESSER (1998), as influências políticas e econômicas interferem na produção do texto jornalístico, além das possíveis divergências que podem surgir de acordo com as linhas editoriais de cada jornal.

Dando início à análise dos sentidos construídos no hipertexto noticioso veiculado pelo jornal brasileiro FO, o título "Líderes se reúnem em Londres para discutir crise com Irã" apresenta os personagens principais. As relações textuais a serem desdobradas por toda a extensão hipertextual, incluindo aí nó e links, encontram-se neste título. Vê-se que "líderes se 
reúnem em Londres" é um indicativo que o jornal brasileiro faz uso a fim de agregar mais relevância ao acontecimento. Assim, líderes reunir-se-ão em uma importante capital européia para discutir um tema delicadíssimo, aspecto que altera a crise iraniana. Desta feita, ela adquire importância substancial não somente devido à proposição “crise com Irã”, que já é de amplitude mundial, mas também à inserção do local onde será realizada a reunião. Assim, os esquemas de conhecimento não serão desencadeados somente a partir da interpretação da crise, mas também de acordo com o local do encontro. No que tange ao L1, "Leia o que já foi publicado sobre a questão nuclear iraniana", este único link elencado pelo jornal brasileiro FO está sob o título "Especial". A começar por este, nota-se que o jornal procura chamar a atenção do interlocutor por meio de uma proposição que indica a ele que uma seção especial foi preparada. O L1 foi construído de modo a intermediar a transposição do interlocutor para um sítio eletrônico no qual se concentram todos os hipertextos noticiosos relacionados à crise nuclear iraniana. É o alerta do jornal ao seu público-leitor de que não há necessidade de migrar para o sítio eletrônico de um outro jornal. A construção textual deste link, no que diz respeito aos aspectos de coerência, retoma o referente "crise com Irã" a partir da proposição “questão nuclear iraniana". Para isso, parte do pressuposto que seu público-leitor reconhece, através de "crise com Irã", que se trata de divergências a respeito de programas nucleares. Assim, é um processo referencial no qual esta primeira proposição passa a ser uma "questão nuclear iraniana". Logo, admite-se que há continuidade de sentidos e, portanto, mesmo este link que remete o interlocutor para um sítio menos específico com relação ao hipertexto noticioso. Neste caso, os links promovem a coerência do hipertexto.

No que diz respeito ao hipertexto noticioso oriundo do jornal alemão FN, inicia-se o texto com "crise nuclear". É uma proposição ampla, mas que, provavelmente, vem sendo utilizada pelo jornal há algum tempo. Por isso, o público-leitor do hipertexto noticioso, ao interagir com ela, já reconhecerá tal proposição como uma divergência com o Irã. O título "Chefe da AIEA, Baradei não descarta violência contra Irã" constrói o hipertexto noticioso a partir de uma visão pessimista de uma autoridade em energia nuclear. Constata-se, portanto, que de fato há uma crise, já que se pressupõe que os muçulmanos não estejam respeitando determinadas regras relacionadas à política atômica no mundo. Assim, se comparado com o primeiro link, "FAZ.NET Especial: crise nuclear com o Irã", pode-se argumentar que o título do hipertexto noticioso e este L1 são coerentes e contribuem para a uniformidade de sentidos no hipertexto. A partir de "crise nuclear", passa-se à proposição global do hipertexto noticioso e aporta-se na "crise nuclear com o Irã". Especificamente com relação ao L1, nota-se que o 
FN elaborou uma seção especial que organiza e disponibiliza reportagens especiais acerca do tema. Ressalta-se que não se trata somente de um amálgama de hipertextos noticiosos concernentes a um determinado acontecimento, mas um caderno diferenciado, para o qual são designados profissionais jornalistas especificamente para cobrir os acontecimentos relativos a este tema. Crucial é ressaltar que o nome do jornal ocupa a primeira posição deste primeiro link. Assim, a construção dos sentidos deste elo acessível concentra-se, em primeira instância, na titulação do caderno especial. Não é somente um especial, mas um "FAZ.NET Especial".

O L2, segundo link elencado FN, toma como referente o presidente iraniano Ahmadineschad. A proposição "Ahmadineschad insiste em pesquisa atômica” retoma um personagem do hipertexto noticioso e, consequentemente, enfoca-o de uma maneira divergente. Apesar de o estudo do nó informativo não ser analisado nesta pesquisa, nota-se que um dos expoentes da crise nuclear pode ser o presidente do país localizado no Oriente Médio, já que ele é um dos referentes utilizados para a construção de sentidos neste L2. Comparando este elo acessível com o lead, o título e o primeiro elo acessível, observa-se que, além de uma continuidade de sentidos, o que atribui aos links coerência, a estratégia do jornal é, gradativamente, recategorizar objetos do texto e, com isso, inserir informações novas a fim de interpretar o fato ao interlocutor. Assim, não basta somente noticiar que há uma crise nuclear com o Irã e que o chefe da AIEA não descarta medidas drásticas contra a nação teocrática, mas também que o presidente iraniano não cessou com pesquisas atômicas. Vê-se que, além de ampliar o fator de informatividade do hipertexto noticioso, o FN orienta o interlocutor a acessar um hipertexto noticioso a partir de um novo tratamento dado ao referente. Logo, a partir de uma continuidade de sentidos, o L2 adquire relevância e, consequentemente, demonstra ao público-leitor que o segundo homem mais importante na escala política do Irã é um dos responsáveis pela crise nuclear e, com isso, pelas prováveis medidas a serem tomadas contra o país. Não se mostra suficiente ao jornal inserir a referência ao presidente no espectro informativo do hipertexto, mas há a necessidade também de enquadrá-lo sob uma nova perspectiva. Vê-se que, neste hipertexto noticioso analisado, os links não possuem a função somente de ampliar a informatividade do hipertexto noticioso, mas também de referenciar aspectos do fato interpretados constantemente pelo jornal.

O L3 parte de um fato não tão distante do conflito nuclear com o Irã. "Vídeo: Bush e Merkel querem solucionar diplomaticamente conflito no Iraque" pode ser observado, em primeira instância, a partir da natureza midiática do link. Assim, trata-se de um elo acessível 
que disponibiliza ao interlocutor a veiculação de notícias por meio de uma linguagem televisiva, ou seja, por meio de imagens e sons. Assim, o jornal alemão opta não somente por interpretar um acontecimento a partir de textos, mas também faz uso das facilidades oferecidas pela tecnologia hipertextual. Com isso, a estratégia jornalística reside na tentativa de alcançar um número maior de interlocutores, ou seja, tanto aqueles que preferem o texto como os que atendem preferencialmente por imagens. Isso não significa que um interlocutor que prefira ambas as linguagens seja descartado. Desta forma, nota-se uma ampliação de linguagens como estratégia do jornal $\mathrm{FN}$ a fim de integrar um número maior de interlocutores. Isso pode se dever à mudança do perfil do público-leitor, bem como a uma tática de ampliação do número de interlocutores. Adiante, observa-se que um acontecimento é inserido no espectro interpretativo do hipertexto noticioso. Como terceiro elo acessível, observa-se que o FN insere dentro do contexto de crise nuclear um país vizinho ao Irã, o Iraque. Ao mesmo tempo em que este terceiro link amplia o contexto do fato, ou seja, crises como essa noticiada não se restringe somente à nação iraniana, a Guerra do Iraque passa a ser elemento de referência no hipertexto noticioso. As proposições iniciais do hipertexto noticioso veiculado no idioma alemão dizem respeito, como já colocado, a uma crise nuclear. A partir da ativação de esquemas cognitivos de conhecimento, é possível, portanto, inserir no contexto as divergências entre americanos e iraquianos, o que resultou na invasão do Iraque em 2003. Nota-se, daí, a importância não somente do lead, que encabeça o hipertexto noticioso, mas também do título. Ambas as categorias do texto jornalístico não atuam somente como concentradores de sentido, mas elencam estrategicamente determinados elementos que formarão uma proposição textual estratégica, de modo que o interlocutor interaja com o hipertexto noticioso e seja levado naturalmente à associação com a Guerra do Iraque. É fundamental observar que o jornal, a partir de proposições como o lead e o título, recategoriza diferentes elementos do texto e, com isso, amplia a alçada de contextualização do fato. Assim, o L3 refere-se a uma possível solução diplomática desejada não somente pelo presidente americano George W. Bush, mas também por Angela Merkel, primeira-ministra da Alemanha. É passível de observação a constante busca pela relevância empreendida pelo FN. Não obstante, a necessidade de aproximar o interlocutor do fato é dada pela inserção da referência à política alemã. Consequentemente, o FN parte da veiculação de um hipertexto noticioso referente a um conflito nuclear com o Irã e aporta na tentativa de resolução diplomática da crise iraquiana. Assim, a delimitação semântico-textual colocada pelo lead e pelo título é atenuada pela construção dos links, fazendo com que os links operem como continuadores de sentidos no hipertexto. Desta feita, introduzem informações novas e, com 
isso, inserem todos os referentes sob a orientação do lead "crise nuclear". Daí, nota-se a gradação de subjetividade conferida ao texto jornalístico, além do efeito de construção de sentidos por meio dos links. Apreende-se, portanto, que os links não se mostram somente como elementos de subsistência do hipertexto, mas, no caso do hipertexto noticioso, atualizam os referentes circulantes e, com isso, ampliam o contexto do fato inserindo hipertextos noticiosos. Pode-se previamente concluir que o hipertexto está baseado em uma rede informativa, mas em cada sítio eletrônico de natureza jornalística situa-se um microuniverso informativo-interpretativo.

Em um trabalho comparativo, observa-se que uma espécie de link está presente tanto no jornal brasileiro quanto no alemão. Trata-se do elo acessível que atua como um portal, ou seja, dirige o interlocutor a um sítio eletrônico organizado e que disponibiliza os hipertextos noticiosos de acordo com um determinado fato. No entanto, eles se diferenciam no aspecto jornalístico, ou seja, no jornal FO trata-se somente de uma listagem de hipertextos noticiosos referentes ao acontecimento interpretado. Já o FN construiu uma seção diferenciada, na qual reportagens especiais foram feitas a fim de atender a necessidade de seu público-leitor. O FN elencou ainda dois outros links, de modo a ampliar o conteúdo informativo e, além disso, interpretar o acontecimento a partir da inserção e atualização de referentes. Com isso, o jornal aumenta a relevância do fato e procura integralizar os acontecimentos, tornando os links não somente elementos fundamentais do hipertexto, mas ferramentas estratégicas de construção de sentidos.

\subsection{Análise de T5, T5.1 e T5.2}

O quinto grupo de hipertextos noticiosos analisado trata da reeleição de Hugo Chávez na Venezuela. Logo que tomou posse no ano de 1999, Chávez dissolveu o Congresso e convocou uma Assembléia Nacional a fim de elaborar uma nova constituição. Ela atribui mais poderes ao presidente e possibilita a intervenção do Estado na economia, além reconhecer direitos culturais e lingüísticos de comunidades indígenas. Tanto nas eleições de 1999 quanto no ano de 2000, seus partidários conseguiram a maioria das cadeiras, o que confere ao venezuelano plenos poderes para exercer seu mandato. Devido a estes acontecimentos, Chávez despertou a atenção para o pequeno país sul-americano e a ira das grandes potências mundiais, 
principalmente dos Estados Unidos. Não obstante, o governo chavista alegou que, no golpe sofrido pelo líder venezuelano no ano de 2002, navios e aviões militares americanos foram detectados por radar, o que sugere intervenções da Casa Branca para depor Hugo Chávez. O presidente da Venezuela ataca com veemência os Estados Unidos e se alinha aos políticos de esquerda de todo o mundo, como os representantes da Coréia do Norte, Irã e Bolívia. Neste ano de 2006 , Chávez foi reeleito com $62 \%$ dos votos, o que demonstra que a maioria do povo venezuelano apóia seu governo e suas atitudes.

Dando início à análise da construção dos links no hipertexto noticioso interpretado pelo jornal brasileiro FO, o título "Chávez comemora vitória com ampla vantagem" concentra-se na vitória do venezuelano devido aos votos obtidos por uma grande margem de diferença com relação ao seu opositor. Nota-se que somente um aspecto do processo eleitoral foi alvo de construção do título, que se concentrou em um dos personagens das eleições venezuelanas, qual seja Chávez. A partir destes elementos textuais, ou seja, "Chávez", "vitória" e "ampla vantagem", o jornal procura ativar no interlocutor conhecimentos acerca do líder político venezuelano. Estes conhecimentos são veiculados ao interlocutor de acordo com a série de divergências criadas por Chávez com os Estados Unidos e outras potências mundiais. Desta feita, ao invés de iniciar o título do hipertexto noticioso com outro elemento textual, a FO optou por começar com o nome do vencedor e polêmico venezuelano. Trata-se, portanto, de uma estratégia do jornal em ativar esquemas de conhecimento relativos ao político e, com isso, trazer o interlocutor através do ineditismo e do inesperado.

Partindo para a análise dos links neste hipertexto, o L1 "Leia o que já foi publicado sobre Hugo Chávez", retoma um dos elementos textuais presentes no título. Se se considerar somente esta observação, fala-se de um aspecto de coerência hipertextual, já que o primeiro elo acessível relaciona-se, textualmente, com "Chávez". Fundamental é notar que, diferentemente da proposição global do hipertexto noticioso, o L1 é construído a partir do elemento "Hugo Chávez". Trata-se do nome completo do político, o que confere ao link não somente a caracterização de um performador de sentidos, mas também de uma ferramenta estratégica que perspectiviza o acontecimento a partir de um ponto de vista não divergente, mas que soma ao que já foi noticiado. Aquilo que é construído a partir dos links não pode ser diferente daquilo que está sustentado no hipertexto noticioso, pois poderia prejudicar a uniformidade de sentidos e, consequentemente, a coerência hipertextual. Não obstante, a linha editorial da FO noticia os fatos a partir de um ângulo, não admitindo outros pontos de vista e 
dirigindo-se ao seu público-leitor como a porta-voz da verdade relevante. Ainda com relação ao L1, a estratégia do jornal reside em demonstrar ao interlocutor um histórico de notícias relacionado ao presidente venezuelano Hugo Chávez, a partir do banco de dados organizado pelo jornal brasileiro. Trata-se de disponibilizar ao interlocutor a construção textual da personagem política através das opiniões da FO. É mais uma opção oferecida ao interlocutor que deseja conhecer mais acerca do líder político. No entanto, com a ilusão de estar sendo informado, o interlocutor aprofunda-se nos julgamentos feitos pela linha editorial do jornal, obtendo uma construção mediada pelos interesses do jornal.

O L2 “Leia o que já foi publicado sobre Manuel Rosales" traz um elemento que não está explicitamente presente na proposição global do hipertexto noticioso. A partir dos apontamentos teóricos realizados acerca das pressuposições, pode-se minimamente afirmar que, em caso de processo eleitoral, há adversários políticos. Assim, faz-se referência ao candidato derrotado a partir de uma referência baseada no processo de pressuposição construído pelo jornal. Apesar de esta pesquisa não empreender análises concernentes ao nó informativo, vê-se que o título dá conta das relações de sentido a serem desenvolvidas no universo hipertextual. Mesmo que a referência ao candidato de oposição tenha sido feita no nó, a observação da construção de sentidos entre título e links é possível, já que são categorias textuais que se referem reciprocamente. Assim, estas categorias mostram-se como eixos de coerência, ou seja, potencializam e esmiuçam os sentidos elaborados no hipertexto noticioso. Desta feita, o segundo link opera como um elemento de coerência e, além disso, foi elaborado de modo a repetir a estratégia de formulação do primeiro elo acessível. A construção da personagem da notícia, que é adversário político de Hugo Chávez, é feita a partir da organização e disposição de hipertextos noticiosos. Estes são obtidos a partir dos bancos de dados do sistema de informações da FO e, com isso, o interlocutor tem a ilusão de que está sendo amplamente informado. "Leia o que já foi publicado sobre..." não se refere a tudo o que se sabe sobre o político venezuelano de oposição, mas somente àquilo que o jornal considera relevante para seu público-leitor. A construção do link a partir desta proposição faz com que o acordo tácito de confiança entre o jornal e seus interlocutores aflore e seja concretizado em formulações textuais. Este "Leia o que já foi publicado sobre..." não é assim compreendido pelo jornal, mas o é pelos interlocutores. Dentre diferentes meios de comunicação e agências de notícias, um jornal tem inúmeras fontes informativas, o que permite a ele a seleção e construção de acontecimentos a partir de perspectivas relativas aos interesses da corporação. 
Assim, a proposição encontrada nos L1 e L2 não se refere à integridade dos fatos, mas sim, a um "Leia o que já foi publicado sobre [...]”, personagem construída pela FO”.

O mesmo processo de construção de sentidos é observável no terceiro link, o L3. "Leia o que já foi publicado sobre a eleição na Venezuela" dirige o interlocutor a um montante de hipertextos noticiosos relativos ao processo eleitoral ocorrido no país. É uma proposição construída na forma de link que rompe com as fronteiras semântico-textuais do hipertexto noticioso a partir do tema "eleição na Venezuela". Considerando-se o hipertexto noticioso como nós e links, apreende-se que os processos de construção de sentidos podem especificar ou ampliar aquilo que está presente no nó informativo. A partir das facilidades oferecidas pela tecnologia de banco de dados, o jornal aproveita-se disso e disponibiliza ao interlocutor todas as informações relacionadas às eleições venezuelanas. Assim, no que diz respeito aos aspectos de coerência deste hipertexto noticioso analisado, este L3 amplia a proposição do hipertexto noticioso, que parte da vitória de Chávez e aporta nas notícias relacionadas às eleições venezuelanas. Apreende-se que o hipertexto não é linear somente em seu aspecto técnico, mas também textual. Não obstante, nota-se como o L1 e L2 retomam referentes explícitos do hipertexto noticioso, ao contrário de L3, que expande o universo informativo e dirige o interlocutor ao acontecimento que gerou a formulação do hipertexto noticioso.

Quanto ao L4 "Leia a cobertura completa da eleição na Venezuela", observa-se que este link diferencia-se devido ao termo "cobertura completa". A divergência de "Leia o que já foi publicado sobre a eleição na Venezuela" reside no aspecto jornalístico, visto que uma cobertura ocorre a partir de reportagens especiais, para as quais repórteres viajam para o país e uma equipe da redação fica no país e trabalha exclusivamente com os acontecimentos relacionados a este tema. Assim, a exemplo do L3, o L4 é um amálgama de hipertextos noticiosos concernentes às eleições venezuelanas. Entretanto, o L4 oferece ao público-leitor da FO uma seção especial que trata do assunto a partir de reportagens diferenciadas e que podem apresentar os fatos de uma maneira mais fiel, o que não significa que não sejam intermediados e avaliados por editores. Desta feita, a "cobertura completa" não desdenha de hipertextos noticiosos que podem ser encontrados quando do acesso ao L3, mas o acesso ao L4 dirige o interlocutor a hipertextos noticiosos especiais. É uma tática jornalística que procura abarcar um número maior de interlocutores, ou seja, aqueles que estão à procura de um determinado hipertexto noticioso e que, para isso, necessitam da disposição cronológica de notícias, e aqueles que preferem uma leitura mais aprofundada e específica. A partir das 
facilidades oferecidas pela informática, o jornal FO faz uso de três links que retomam referentes explícitos ou implícitos do título, quais sejam "Hugo Chávez", "Manuel Rosales" e “eleições na Venezuela". Forma-se, portanto, um contexto no qual duas personagens políticas travaram uma batalha, já que se sabe do resultado final. Assim, abre-se espaço para aqueles interlocutores que procuram por interpretações esmiuçadas de fatos e acontecimentos relacionados às eleições venezuelanas. O jornal brasileiro FO parte do mais específico e aporta nas construções textuais mais gerais, contextualizando o acontecimento a partir do uso dos links.

No que diz respeito ao hipertexto noticioso veiculado pelo FN, o selo "Eleições presidenciais na Venezuela" comunica ao interlocutor o assunto de que trata o hipertexto noticioso, já que se trata de uma série deles relacionados ao mesmo fato. A partir dessas proposições, esquemas de conhecimento serão ativados, levando o interlocutor ao título "Vitória clara para Chávez". Nota-se que este jornal optou por um título que engloba todas as relações de sentidos a serem construídas no hipertexto, já que o assunto da notícia é a vitória de Chávez nas eleições presidenciais venezuelanas. Observa-se, no entanto, que a ampla margem de votos obtidos pelo polêmico líder político é mais importante, para o FN, do que a sua reeleição. "Vitória clara" antepõe-se ao termo "Chávez" e, desta maneira, não basta somente a reeleição de um político que chegou ao poder por meio de golpes políticos, mas também importante é o seu grande apoio popular. A partir de um tema amplo, a proposição global do hipertexto noticioso complementa a informação dada pela primeira categoria. "Eleições presidenciais na Venezuela" e "Vitória clara para Chávez" são proposições que se interagem, de modo que as eleições presidenciais já foram vencidas pelo candidato favorito. Desta feita, ativam-se sentidos que vão se especificando no decorrer do hipertexto noticioso. Falando-se do universo informativo hipertextual, são construções textuais que, a partir de uma proposição ampla, sugerem interatividade ao interlocutor. Esta centração temática, que vai do mais geral ao mais específico, permite ao jornal elencar links que apreendam eventos ou anteriores ou posteriores ao hipertexto noticioso analisado.

Com relação ao L1, "Presidente Chávez da Venezuela antes da reeleição", observa-se que o processo de construção de sentidos expande as linhas limítrofes colocadas pela proposição global do hipertexto noticioso. A partir da veiculação do fato de que Chávez vencera as eleições presidenciais venezuelanas, o FN, a partir da construção de um elo acessível, remete o interlocutor a um hipertexto noticioso que antecedeu a vitória do 
candidato. A partir do uso de um banco de dados construído pelo jornal, elaborou-se um link que mostra como era Chávez antes de sua reeleição. Frisa-se que a retomada do referente altera a perspectiva lançada pelo jornal. Assim, Chávez não é mais o vencedor das eleições presidenciais, mas será encarado, a partir deste elo acessível, de acordo com eventos históricos que aportarão na vitória eleitoral. Se se considerar o papel do selo no que tange às construções de sentido neste hipertexto noticioso, nota-se que este L1 transgride a delimitação textual colocada exatamente por esta categoria que procura ser abrangente. $\mathrm{O}$ título é tratado aqui como a instância concentradora de sentidos e que abriga em seu conteúdo as relações semântico-textuais a serem desenvolvidas no decorrer do texto. No entanto, este primeiro elo acessível trata de Chávez antes da reeleição, o que sugere um novo tema no universo textual do hipertexto.

No que tange ao L2 "Hugo Chávez e 'amigos': União contra Washington", tem-se novamente a referência ao presidente reeleito. Mais uma vez observa-se a reconstrução deste referente dentro do espectro textual. Chávez, neste elo acessível, faz parte de um pelotão que tem como único objetivo derrotar Washington, ou seja, o governo americano. Além disso, nota-se que "amigos" se encontra entre aspas. Desta maneira, o FN refere-se aos simpatizantes políticos do líder venezuelano como "amigos", sugerindo que eles estão somente alinhados a fim de derrotar a exploração empreendida pelo governo americano. A "união" nada mais é que esta simpatia política que leva um grupo de determinados países a se oporem à política capitalista praticada pelos Estados Unidos. Observa-se o aproveitamento da estrutura hipertextual para que não somente o referente seja ressignificado, mas para que novas informações sejam ancoradas a partir do contexto construído desde o selo. Desta maneira, outros contextos vão sendo formulados a partir do hipertexto noticioso relacionado à ampla vitória de Chávez nas eleições venezuelanas e, consequentemente, um amplo contexto vai sendo formado, à medida que novas informações são introduzidas no hipertexto noticioso. A partir de construções de sentidos que retomam referentes já existentes no hipertexto noticioso, o L1 e o L2 vão, aos poucos, elaborando um esquema textual que não tange somente ao nó, mas também à organização dos links.

Analisando-se o L3 "Equador: Correa vence eleições presidenciais", vê-se que o quesito de proximidade à notícia também impulsiona o jornal a comunicar acontecimentos relativos à eleição venezuelana. De acordo com os sentidos construídos a nas categorias que formam este hipertexto noticioso, nota-se que não é somente o fato do Equador ser vizinho da Venezuela 
que estimulou o FN a inserir uma hipertexto noticioso relativo às eleições equatorianas. De acordo com as primeiras categorias textuais, o hipertexto noticioso trataria somente do processo de escolha política do líder venezuelano. No entanto, esta premissa alterou-se quando se analisou acima os dois primeiros links. Estrategicamente, o jornal foi remetendo o processo eleitoral de Chávez a um contexto mais amplo, ou seja, às linhas políticas crescentes na América Latina. Assim, a partir de um texto linear, o jornal alemão insere informações novas que amplia não somente o aspecto de informatividade do texto, mas também o mundo textualizado e comunicado pelo jornal. Não basta somente noticiar que Chávez foi eleito democraticamente na Venezuela, mas também associar o país a uma outra nação que passa pelo mesmo momento. Fundamental é notar a intermediação feita pelo segundo elo acessível, que alinha os simpatizantes políticos de Chávez ao presidente recém eleito do Equador, que é inserido na linha política esquerdista. Consequentemente, o FN amplia o contexto da larga vitória chavista em território venezuelano e, concomitantemente, insere neste pano de fundo a eleição de Correa no Equador. Observa-se também a construção de sentidos entre os links. Assim, tem-se um Chávez antes das eleições, um Chávez integrante de um grupo avesso aos Estados Unidos e, por fim, uma sombra de Chávez sendo eleito na nação equatoriana. O L3 é coerente pela produção de sentidos empreendida nos dois links anteriores, o que insere Correa no contexto esquerdista da política global.

Comparando-se os dois hipertextos noticiosos, notam-se estratégias divergentes tanto a respeito da coerência construídas nos links quanto das estratégias jornalísticas. No jornal brasileiro FO, links que funcionam como portais agregadores de hipertextos noticiosos relacionados a um mesmo acontecimento foram elencados. Desta maneira, este jornal optou por construir dois links que oferecessem ao interlocutor uma série de hipertextos noticiosos a partir de referentes trabalhados no decorrer do hipertexto noticioso. "Hugo Chávez", "Manuel Rosales" e "eleição na Venezuela" são as proposições elencadas pelo jornal brasileiro, que ressignificam elementos textuais do título. A partir deles, o jornal cria uma espécie de polarização no encadeamento dos links. Desta forma, os três elementos, apesar de se encontrarem fora do nó informativo, contribuem para a continuidade de sentidos do hipertexto e, por isso, são elementos de coerência do hipertexto noticioso. Um pouco destoante da característica destes três links é o L4, elaborado a partir da indicação de uma seção especial referente ao processo eleitoral venezuelano. Estes links contribuem mais para a estratégia jornalística de mostrar ao interlocutor as compilações de hipertextos noticiosos possibilitadas pelo banco de dados da FO. Já o FN retomou referentes presentes no hipertexto noticioso e os 
ressignificou de modo a inserir novas informações no universo informativo do hipertexto. Consequentemente, o contexto de elaboração do hipertexto noticioso foi ampliado, de modo a possibilitar a inserção de novos referentes e até mesmo de um hipertexto noticioso indiretamente relacionado com as eleições venezuelanas. No aspecto referencial, o FN incluiu diretamente hipertextos noticiosos concernentes à eleição de Chávez, atribuindo relevância ao fato. Por outro lado, a FO preferiu linkar uma seção especial, que procura captar interlocutores desejosos de análises mais aprofundadas, e links que demonstram uma compilação de hipertextos noticiosos relativos a três elementos do hipertexto noticioso. Desta feita, trata-se de uma tentativa de organização e sustentação das opiniões defendidas pelo jornal.

\subsection{Análise de T6, T6.1 e T6.2}

A sexta dupla de hipertextos noticiosos analisada refere-se às eleições parlamentares palestinas ocorridas no início do ano de 2006 vencidas pelo partido político Hamas, o qual não reconhece a existência do estado israelense. Após a vitória, tanto Estados Unidos quanto Israel afirmaram que não manteriam relações diplomáticas com o novo governo, já que dissidências armadas do Hamas são acusadas de promover diversos atentados terroristas, principalmente por meio de homens-bomba. A eleição democrática de um partido com núcleos armados deve-se, em parte, ao falecimento do primeiro-ministro Yasser Arafat, membro da Fatah, partido que dominou a política palestina por muitos anos. Com isso, a oposição direitista afluiu e outros esforços que tinham como objetivo a paz político-social no Oriente Médio malograram. Um deles foi o acordo de Camp David, assinado em 1994 por Arafat e pelo ex-premiê israelense Yitzhak Rabin em Washington, sob a intermediação do expresidente americano Bill Clinton. Sabe-se que a expansão do terceiro Reich alemão teve como diretriz política a depuração da raça e uma das maiores vítimas deste ideal foram os judeus. Calcula-se que ao menos seis milhões deles foram mortos entre as décadas de 30 e 40 . Este foi um dos argumentos para a criação do estado de Israel. Não obstante, a participação político-militar do governo alemão na questão palestina tem sido mais ativa do que as influências de origem brasileira. Para os veículos de comunicação brasileiros, o fato tem repercussões globais e não diretas, como ocorre na Alemanha, que tem o holocausto enraizado 
em sua cultura. A partir disso, aguardam-se diferenciações no que diz respeito à abordagem do fato pelos jornais $\mathrm{FO}$ e FN.

A FO ressalta no título "Resultados apontam vitória do Hamas nas eleições palestinas" que os prognósticos são favoráveis ao partido político com grupos armados, evitando noticiar o fato como consolidado. O jornal mostra-se cauteloso quanto ao acontecimento e, à primeira vista, procura não se comprometer. Paradoxalmente, a construção da proposição global deste hipertexto noticioso, caracterizado como desengajada, comunica o acontecimento de maneira descrente, evidenciando-se, portanto, a opinião do jornal. Revela-se, portanto, uma descrença não no fato em si, mas num possível fato futuro que não vai de encontro aos interesses sustentados pelo jornal. A utilização do verbo "apontam" não chega a extrapolar as convicções jornalísticas de que uma notícia é a interpretação de uma verdade (LAGE: 2001), mas veicular aos interlocutores um fato que ainda não se consumou integralmente. Não agrada à comissão editorial do jornal brasileiro comunicar ao seu público-leitor a subida do Hamas ao poder parlamentar na Palestina. Por outro lado, observa-se que este descontentamento reflete-se na construção do título do hipertexto noticioso. A relutância ao concretizar o fechamento dos resultados eleitorais por meio do texto diz respeito ao caminho tangencial percorrido pelo jornal a fim de evitar uma notícia com uma proposição global do tipo "Hamas vence as eleições palestinas" ou "Fatah perde as eleições na Palestina".

Referente ao L1, intitulado "Eleições parlamentares palestinas terminam em Gaza e Cisjordânia", o jornal procura, em primeiro lugar, contextualizar os acontecimentos, de modo a situar o interlocutor tanto em relação à geografia quanto à história da região. A citação destes dois países aloca o interlocutor no que diz respeito aos territórios geográficos que compreendem a região palestina. A função precípua deste primeiro link é contextualizar o hipertexto noticioso de modo a recategorizar o referente "Palestina". Entretanto, esta referenciação não se dá integralmente, pois o link comunica ao interlocutor que as eleições parlamentares palestinas terminaram somente em Gaza e na Cisjordânia. Apreende-se, portanto, que há votos que ainda não foram apurados e, consequentemente, eleitores de outros países também participam, votos dos quais ainda não foram suficientes para a confirmação da vitória do Hamas. Fundamental é observar que a FO reitera a construção de sentidos observada na proposição global do hipertexto noticioso. Assim, os resultados indicam que o Hamas pode se sagrar vencedor das eleições parlamentares palestinas. Essa é a proposição inicial. No entanto, ela é retomada de forma a alertar o interlocutor de que os votos foram 
totalmente apurados somente em Gaza e na Cisjordânia, dois dos países que participam das eleições parlamentares palestinas. O jornal brasileiro faz uso de um dos elementos do hipertexto para se centrar de acordo com as opiniões defendidas por ela. Assim, além de interpretar ao interlocutor um acontecimento referente às eleições, a FO ressignifica os objetos do texto a fim de reforçar o seu ponto de vista por meio do aproveitamento da arquitetura hipertextual.

No que concerne ao L2 "Partido governista Fatah reconhece derrota em eleições palestinas", o jornal brasileiro reitera seu cuidado com a produção de sentidos e relata os pronunciamentos do partido político Fatah acerca da futura derrota para o Hamas. Vê-se que se trata de uma atribuição de responsabilidades ao partido do ex-premiê Yasser Arafat. A partir do momento em que o jornal faz uso de citações ou intertextualidades implícitas (KOCH: 2003), ela insere no universo textual opiniões expressas por personagens ou instituições. Por outro lado, ao fazer uso de tais construções de sentido, o jornal mostra-se como ativo não somente no que concerne à tessitura textual, mas também às estratégias de construção dos sentidos. Além de não se tratar de um link destoante da proposição global, o L2 deixa para os políticos da Fatah o reconhecimento da derrota. Ora, se o jornal brasileiro ainda não o fez, seria incoerente de sua parte elencar um link que afirmasse a derrota da Fatah. No entanto, esta cautela não se relaciona unicamente ao fato de o jornal não se comprometer com aquilo que está sendo comunicado. O veículo brasileiro evita a afirmação em seu título, mas, de maneira estratégica, reporta que a própria Fatah reconhece a derrota. Nota-se, portanto, ambigüidades no que se refere à construção discursiva hipertextual, já que, ao mesmo tempo em que afirma a vitória não-oficial do Hamas, elenca-se o L2 como um hipertexto noticioso que tem como estrutura global de sentidos justamente a ratificação da derrota do partido político Fatah. Essa estratégia é aqui compreendida como a interpretação de uma conseqüência ainda não consumada.

O L3 tem como título "Cobertura completa das eleições palestinas". Depreende-se que este link atua como um portal, notada a abrangência da proposição colocada. De acordo com Barbosa (2001), portais funcionam como agregativos de um caos informativo, pois agrupam em seu conteúdo temas relacionados a uma estrutura temática global. Advém, daí, o conceito de informação de proximidade (STORRER: 2002), definido a partir de uma coerência de interface, que é a disposição informativa de fácil observação e acesso, organizadas a partir de um tema de interesse. Não obstante, o portal disponibiliza ao interlocutor links que remetem a 
outros sítios e que, no caso de sítios noticiosos, procuram cercar o fato com um grande número de notícias com uma mesma linha interpretativa. Afirma-se, então, que a FO tem o intuito de dirigir o interlocutor a outros hipertextos noticiosos de maneira estratégica, potencializando seu papel interpretativo e focalizando os fatos de acordo com sua linha editorial.

O próximo link, o L4, tem o mesmo propósito, porém mais amplo. Ao acessá-lo, o interlocutor vê-se diante da possibilidade de obter informações não somente das eleições palestinas, mas também de todas as notícias relacionadas e disponibilizadas pelo banco de dados do jornal brasileiro. Conseqüentemente, o jornal brasileira amplia ainda mais seu potencial interpretativo e, estrategicamente, aparenta comunicar ao interlocutor todos os fatos relacionados aos atores do hipertexto noticioso, entre os quais, Fatah, Hamas, Sharon, Gaza, Cisjordânia, Israel e outros. Assim, a FO remete o interlocutor a um hipertexto que abriga uma lista de links relacionados à estrutura temática global do primeiro hipertexto. Em dois links, L3 e L4, o jornal online consegue atualizar o hipertexto noticioso veiculado e, com isso, construir um texto estrategicamente potencializado, com ligações a outros hipertextos com temas semelhantes, o que perfaz uma continuidade de sentidos. No entanto, o fundamental encontra-se nesta coexistência hipertextual de notícias que elencam diversos elementos semanticamente relevantes, ou seja, aqueles que sintetizam as proposições cruciais para a interpretação hipertexto noticioso. O hipertexto noticioso construído por esto jornal tece uma coerência textual que delimita e focaliza o acontecimento a partir de um acúmulo informativo organizado a partir destes links. A uniformidade semântica e a quantidade de notícias organizadamente dispostas atuam como estruturas de persuasão no que concerne à permanência do interlocutor nas leituras dos hipertextos noticiosos veiculados pela FO.

Nota-se que o FN tem como proposição global "Depois da vitória do Hamas governo Fatah sai de cena na Palestina" de seu hipertexto noticioso não somente o fato de o Hamas, um partido político palestino com dissidências armadas, ter vencido as eleições. O jornal ressalta a conseqüência das eleições, ou seja, que a supremacia da Fatah, a instituição política adversária ao partido vencedor, chegou ao fim após décadas de hegemonia no território da Palestina. É importante sublinhar que "O Governo Fatah sai de cena na Palestina" é o subtítulo da notícia. No entanto, apesar de se encontrar subordinado à manchete, o subtítulo também representa, em conjunto com o título, o tema global do hipertexto noticioso, pois 
alinha referentes no início do hipertexto que irão se somar às proposições colocadas na proposição global.

Com relação aos links do FN, observa-se que o L1 "Hamas ganha eleições palestinas" procura abranger o interlocutor de modo a disponibilizar não somente textos, mas também imagens. $\mathrm{O}$ ato de elencar um vídeo que pode ser acessado altera o modo informativo comum à prático jornalística, já que com um suporte multisemiótico, ou seja, que abriga textos, imagens, sons e vídeos, a cobertura de um acontecimento não se restringe às palavras. $\mathrm{O} F N$ faz uso da arquitetura hipertextual multimídia a fim de transmitir a notícia por meio de diferentes códigos, com os quais o interlocutor tem a possibilidade de ampliar o seu olhar observador com relação àquilo que foi somente textualizado quando do início da leitura do hipertexto noticioso.

Adiante, a construção de L2 "Vitória do Hamas: como na Alemanha em 1933" reitera as considerações de que os modelos que fundamentarão a coerência textual efetuam-se nas instâncias comunicativas e caracterizam-se, portanto, como sociais (cf. KOCH: 2004). A construção do hipertexto noticioso veiculado pelo jornal alemão pressupôs que seus interlocutores, daí os apontamentos que consideram a produção textual a partir de referentes sociais, pudessem estabelecer referências com a história alemã, especificamente, com a ocupação do cargo de chanceler por Adolf Hitler em 1933 que, após a morte do Barão de Hindenburg, torna-se o chanceler da Alemanha. Elencou-se, portanto, o segundo link como uma repetição da história política alemã, alocada na Palestina, que será governada por um partido político com dissidências armadas. Constrói-se um hipertexto noticioso baseado não somente nos acontecimentos que são deflagrados no Oriente Médio, mas o jornal incorpora o fato ao panorama evolutivo alemão, aproximando seus interlocutores, tornando o hipertexto noticioso mais relevante.

Concernente ao L3 “Os palestinos votam”, o FN elencou um vídeo, estratégia pela qual o hipertexto noticioso passa a ser multimidiático, de forma que o interlocutor informa-se não somente por meio de textos, mas também através de um vídeo. Este primeiro aspecto técnico revela a possibilidade de se interseccionar diferentes suportes que contribuem para a interpretação de um acontecimento. Adiante, o link "Os palestinos votam" mostra a concisão empregada quando da produção do mesmo, de modo a exprimir brevemente um acontecimento histórico, dada a vitória democrática do Hamas nas eleições palestinas. Este 
simples "votam" não se refere somente ao ato de votar, mas também às conseqüências que isso pode trazer. Mostrando os eleitores que votam de maneira consciente e livres de pressões que justificariam a vitória do grupo político através de imagens, o FN estabelece uma linha contínua de sentidos entre estas diferentes mídias.

O L4 "Palestinos escolhem parlamento" noticia como o parlamento palestino é formado, informando um dos muitos aspectos políticos palestinos, que não se restringem somente às batalhas entre a Fatah e o Hamas. O FN interpreta ao interlocutor uma disputa política democraticamente travada, ausentando-se de um discurso comum a respeito das freqüentes agressões principalmente da parte do Hamas, partido político com dissidências armadas. Paralelo ao link anterior, este L4 amplia a interpretação do fato para a escolha do parlamento palestino, instituição que irá votar e decidir os aspectos político-sociais do povo que habita a região.

Adiante, na análise de L5 "Traqueostomia em Sharon: operação foi um sucesso" vê-se que o hipertexto noticioso tem na estrutura temática dois referentes que representam o povo palestino, os quais Fatah e Hamas. No entanto, os conflitos árabe-israelenses não foram deixados de lado quando da elaboração do hipertexto noticioso. Apreende-se que os jornalistas alemães procuram associar os conflitos palestinos com o ex-premiê israelense Ariel Sharon, até então incapacitado de exercer funções políticas. Pressupõe-se, até mesmo, que o estado vegetativo do líder de Israel tenha deliberado o descontrole político que resultou na derrota da Fatah na Palestina, possibilitando o governo a um grupo que abriga militantes que primam pela violência. É um link que interpreta a notícia de modo a remeter o interlocutor ao hipertexto noticioso que tem como estrutura global de sentidos o estado de saúde de Ariel Sharon. Conseqüentemente, a coerência do hipertexto analisado elenca como referente não somente a disputa entre Fatah e Hamas, mas a associa à quase-morte de um líder que procurou dialogar com os palestinos, ato que despertou a ira de muitos judeus. A relação política do Oriente Médio, portanto, foi objeto de produção de sentidos no FN. Não obstante, a ascensão de Adolf Hitler, consagrada em 1933, é comparada à vitória do Hamas, o que faz com que a interpretação do hipertexto noticioso esteja associada a uma tragédia anunciada do povo palestino.

Efetuando uma análise comparativa, observa-se que os títulos possuem relações de sentido com seus respectivos links, ou seja, promovem uma continuidade de sentidos com os 
links. Ressaltando que a macroestrutura é o agrupamento que codifica as relações de sentido existentes em um texto e que este é o desdobramento focalizado e delimitado de categorias semântico-estruturais (cf. van DIJK: 2002), nota-se que os links, que são parte integrante de um hipertexto, são mais do que paratextos (cf. MIELNICZUK \& PALÁCIOS: 1999). Eles representam mais do que potencializadores de intertextualidade, visto que a ressignificação dos conceitos presentes no texto é instantânea, dada a característica não-linear da rede. Os links são ferramentas que recortam a realidade de acordo com os valores sustentados no hipertexto noticioso. Com relação ao hipertexto noticioso do jornal alemão FN, vê-se que a construção dos links é hipermidiática, ou seja, há à disposição do interlocutor além de mais três hipertextos, um vídeo que mostra a reação dos palestinos com relação aos resultados eleitorais e outro que enquadra os palestinos exercendo o papel de cidadãos. Assim, o jornal alemão faz uso da arquitetura hipertextual para enfocar o fato através de imagens, ampliando a sua oferta informativa para além do texto. A construção dos links levou em conta as pressuposições que o interlocutor pode realizar quando da interpretação do hipertexto noticioso. Evoca o passado histórico da Alemanha, bem como estabelece uma linha de entendimento que relaciona os fatos ao estado vegetativo de Ariel Sharon, ex-premiê israelense. Com relação ao hipertexto noticioso da FO, a mesma preferiu a construção de links que remetessem o interlocutor a portais. Estes, por sua vez, procuram cercá-lo com a disposição organizada de links com tema semelhante à do hipertexto noticioso inicial.

Assim, afirma-se que estes links analisados são fatores de coerência hipertextual, pois perfazem uma continuidade de sentidos e originam-se da ativação de referentes localizados no hipertexto noticioso. Ambas os jornais operam os links de maneira estratégica, já que oferecem acessos a outros hipertextos que mantém as opiniões sustentadas pelos jornais online. O veículo alemão cumpre tal tarefa de maneira mais anafórica, ou seja, de modo a relacionar a notícia com sua interpretação refletida nos links. Por outro lado, a FO elenca seus links de modo a abranger a interpretação do fato, sugerindo ao interlocutor sítios que abrigam em sua arquitetura todos os links que remeterão a outras notícias semelhantes àquela interpretada. Trata-se de dirigir o interlocutor exoforicamente a outros hipertextos, mas não se ausentando do sistema hipertextual do jornal. 


\subsection{Análise de T7, T7.1 e T7.2}

O sétimo grupo de hipertextos noticiosos trata de um acontecimento relacionado ao exditador iraquiano Saddam Hussein. As palavras "ditador" e "iraquiano" ecoam como polêmicas se conduzidas por temáticas concernentes à paz mundial e ao unilateralismo americano. Em primeira instância, Hussein foi um dos grandes ditadores do mundo árabe e governou o Iraque de forma totalitária durante os anos de 1979 a 2003 e acumulou o cargo de primeiro-ministro nos anos de 1979 a 1991 e 1994 a 2003. Sob o governo de Saddam Hussein, o Iraque é um país que se envolveu, nas últimas décadas, em três guerras: a Guerra Irã-Iraque (1980-1988); a Guerra do Golfo (1991-1991) e a Guerra do Iraque (2003-2003). Nesta última, o ex-ditador foi capturado por forças estado-unidenses e curdas e considerado prisioneiro de guerra. Detido, foi julgado e considerado culpado por dois genocídios contra curdos e iraquianos xiitas ocorridos em 1980 e 1982. Entretanto, o julgamento transcorreu de maneira conturbada, com o assassinato de três advogados de defesa, inúmeras interrupções e a renúncia do juiz Rizgar Muhammad Amin no julgamento do político sunita. No ano de 2003, a Alemanha era um dos membros temporários do Conselho de Segurança da Organização das Nações Unidas (ONU). Levando-se em conta o posicionamento tomado pelo ex-chanceler alemão Gerhard Schröder, o qual foi abertamente contra a Guerra do Iraque, comportamento também adotado pelo Conselho, apreende-se que o envolvimento político da Alemanha foi mais intenso se comparado ao brasileiro. Por outro lado, Luiz Inácio Lula da Silva considerou por suficiente emitir uma nota afirmando que qualquer tipo de guerra seria prejudicial à paz mundial. Dados estes fatos, a comparação entre hipertextos noticiosos oriundos de um jornal brasileiro e de outro alemão podem revelar posicionamentos distintos ou semelhantes no que diz respeito à construção de sentidos. Desta maneira, espera-se observar se os links elencados pelos jornais contribuem para a coerência hipertextual e de que maneira ela é desenvolvida.

O estudo da coerência textual tem início no título, dado o seu papel semântico-textual de desencadeador de proposições a serem desenvolvidas no decorrer do texto. Nota-se, em primeira instância, que o FO destacou a notícia hipertextual por meio do título "Juiz do exditador do Iraque apresenta carta de renúncia”. Enfatiza, em primeira instância, o juiz como um proprietário de Hussein. A preposição "do" não transparece a idéia que se passa um julgamento no qual se encontram advogados de acusação e defesa, juizes, réus e acusadores. O jornal procura demonstrar a condição do ex-ditador iraquiano e, consequentemente, a sua 
complacência para com a invasão americana ao país islâmico. "Juiz do ex-ditador do Iraque [...]" é aqui interpretado com um duelo dicotômico que pode ser comprovado por algumas críticas tecidas à configuração do julgamento do ex-ditador iraquiano. Como foi julgado por um tribunal designado pelo Governo Provisório do Iraque, instalado após a queda de Hussein, o embate entre sunitas, xiitas e curdos iria, de qualquer forma, aflorar. Sabe-se que Hussein era sunita e promoveu genocídios contra os outros dois povos iraquianos. Desta feita, não se cita o nome do juiz, tampouco o do ex-ditador iraquiano. Com a ausência de nominalizações, os referentes tornam-se amplos e as posições sociais tornam-se mais claras. Assim, é uma batalha empreendida entre um juiz e um ex-ditador, na qual diferenças serão resolvidas a partir do julgamento de critérios impostos pelo designado do Governo Provisório. Por isso, o juiz é "do ex-ditador" e não o contrário. Entretanto, a continuação do título "[...] apresenta carta de renúncia" revela que, apesar de estar sendo julgado e acusado, é o juiz quem recebe a punição. $\mathrm{O}$ fato de renunciar em um embate dicotômico leva a vitória a Hussein e o porta-voz da justiça, no caso o juiz, sai de cena. Instaura-se um binômio entre o juiz e o ex-ditador, no qual o primeiro prevalece, já que tem a posse sobre o segundo.

No que diz respeito ao L1 "Leia o que já foi publicado sobre o julgamento de Saddam Hussein", vê-se que elencou-se uma construção colocando-se como um dos referentes o nome "Saddam Hussein". Observa-se que há uma relação semântica entre título e o respectivo link, de modo a remeter o interlocutor a uma série de hipertextos noticiosos, nas quais o ditador é um dos referentes. Desta maneira, reitera-se a construção de sentidos observada no título do hipertexto noticioso, na qual se desenhou um digladiar de forças entre o juiz e o ex-ditador iraquiano. O jornal centrou a construção do primeiro e único link na figura de Hussein, o que comprova as hipóteses elaboradas concernentes ao título. Sendo assim, o FO optou por demonstrar ao interlocutor a sua variedade informativa, construindo um link que se dirige a outros links, em uma seção intitulada "Especial". Também se observa que o jornal considera relevante para a manutenção do interlocutor no sítio que o link seja de tal maneira elaborado, a fim de citar o nome do ex-ditador iraquiano, relegando o presente fato a segundo plano. Logo, a construção do hipertexto noticioso orientada pela constante referência ao ex-ditador iraquiano é fundamental não somente para informar o interlocutor, mas também para apresentar a perspectiva e as opiniões do jornal em relação a uma série de acontecimentos que se originaram da captura do político sunita. Apreende-se, portanto, que tal maneira de construção do link é um artifício estratégico que se apresenta mais do que uma proposição textual, mas sim, como uma macroproposição (van DIJK: 2002). A FO fez uso de um 
referente, a fim de suscitar o interesse em interagir com outras notícias relacionadas a este referente. Assim, interpreta os acontecimentos de forma a dirigi-lo gradativamente a outros hipertextos noticiosos. Essa construção textual estratégica tem como objetivo evitar que o interlocutor visite outros jornais, nos quais as opiniões e valores sustentados podem ser outros. Assim, a desconstrução do texto elaborado pelo jornal brasileiro poderia ser realizada instantaneamente, dadas as facilidades oferecidas pela rede mundial de computadores.

Concernente às observações empreendidas acerca do hipertexto noticioso veiculado pelo FN, nota-se que o título "Juiz responsável no processo contra Saddam renuncia" faz novamente uso do nome de "Saddam". Elenca-se, portanto, o referente que é o protagonista principal deste e de outros fatos que serão interpretados pelo jornal. Outro referente do hipertexto noticioso é o juiz responsável pelo julgamento do ex-ditador iraquiano. Considerando-se que a macroestrutura (van DIJK: 2002), representada no título, aglutina os desdobramentos semânticos a serem realizados através do desenvolvimento do hipertexto noticioso, observa-se que o FN elaborou uma proposição global que nominaliza somente o exditador iraquiano. Assim, ele ganha visibilidade na construção de sentidos operada no hipertexto noticioso, pois se trata de uma reatualização de referentes a partir da utilização de um nome próprio. É crucial ressaltar que as relações factuais concernentes ao processo de julgamento foram textualizadas pelo FN, de modo a estabelecer as posições de cada um dos referentes. $\mathrm{O}$ jornal atualiza os fatos de modo a informar a equivalência entre ambos os referentes, ou seja, o réu é acusado, mas tem o direito de se defender de acordo com as interpretações feitas pelo juiz responsável.

Analisando-se o L1, vê-se que foi empregada a mesma estratégia textual, ou seja, novamente os referentes utilizados na construção do título foram elencados no primeiro link. No entanto, observa-se que ambos foram colocados como opositores, já que "Processo contra Saddam: juiz Amin impõe-se" pode ser interpretado como um processo germinado pelo juiz Amin e não por um tribunal organizado pelo Governo Provisório do Iraque. Isso é comprovado pelo uso do sinal de dois pontos, que tem a função aqui de isolar o referente e dar destaque ao mesmo. Entretanto, a construção de sentidos observada neste primeiro link realiza o movimento contrário daquela notada na proposição global do hipertexto noticioso. Pressupõe-se que, de acordo com o título "Juiz responsável no processo contra Saddam renuncia”, a temática do texto diz respeito especificamente à renúncia do juiz. Já neste primeiro link é a referência ao juiz que norteia sua produção, o qual vinha orientando o 
julgamento do político sunita. Vai se informando ao interlocutor o background (van DIJK: 2002) dos acontecimentos. No entanto, a história do fato não se resume a um jogo dicotômico entre o acusado e o juiz, mas sim, a uma série complexa de ocorrências. Isso demonstra a posição editorial do FN, que recorta o acontecimento de modo a instituir um duelo entre o juiz Amin e o ex-ditador iraquiano Saddam Hussein. Vê-se, portanto, que o FN comunica a notícia de modo a concentrar o texto nos dois protagonistas principais. Além disso, este primeiro elo acessível sustenta a construção do título, pois, perspectiviza os referentes novamente e, com isso, dá continuidade à macroproposição inicial do hipertexto noticioso.

Com relação ao L2 elaborado pelo FN "Vídeo: Saddam não comparece ao tribunal”, constrói-se um link que retoma, por mais uma vez, um referente já presente no título e no primeiro link. "Saddam", após ser enquadrado como um réu que obrigou um juiz a renunciar e como um acusado em um processo no qual um juiz é responsável, é reatualizado de forma a se discorrer acerca de sua relutância com relação ao processo de julgamento. $O$ jornal faz uso de estratégias textuais de construção de sentidos a fim de atribuir ao fato outras interpretações, ampliando a veiculação de acontecimentos a partir da ressignificação constante de um referente tecido no hipertexto noticioso. Assim, na aparência de informar o interlocutor através do uso de links, o FN tece sentidos que recortam o fato de acordo com as opiniões editoriais. Além disso, este L2 atrai o interlocutor de modo a oferecer informações a partir de uma estrutura hipermidiática, ou seja, por meio da disponibilização de um vídeo. Este, provavelmente, mostrará um Saddam rabugento e que se nega a ser julgado por crimes que desconhece. Nota-se que a construção de sentidos observada na proposição global deste hipertexto noticioso e a analisada no L1 é contínua, ou seja, os links contribuem para a elaboração de sentidos no hipertexto noticioso. No que diz respeito ao aspecto técnico, o FN faz uso de seu banco de dados que armazena não somente hipertextos, mas também vídeos. Assim, inclui no rol de links um vídeo que provavelmente demonstrará Saddam negando o processo de julgamento por genocídio contra curdos e iraquianos, ausentando-se do mesmo. Desta maneira, o jornal alemão opta por listar não somente textos, mas também vídeos que alcancem um número maior de interlocutores, além de oferecer dois meios de comunicação possíveis na Internet. Aproveita, portanto, as facilidades oferecidas pela rede e, além disso, demonstra ao seu público-leitor a necessidade de informá-lo através de outras mídias.

Já com relação ao L3 "Saddam não comparece ao tribunal”, vê-se uma repetição do L2, só que agora a notícia é veiculada por meio de um outro código, no caso, o texto. Assim, o FN 
elabora uma combinação de mídias a fim de informar mais integralmente o interlocutor ou, considerando-se uma segunda alternativa, procura atingir diferentes tipos de interlocutores, ou seja, aqueles que preferem textos e aqueles que preferem vídeos. No caso do terceiro elo acessível, dá-se continuidade a dicotomia construída pelo FN, de modo a elaborar um digladiar de forças entre o tribunal, inicialmente representado pelo juiz Amin, e o ex-ditador iraquiano. O L3 constrói o fato por meio do desdém dispensado por Saddam ao tribunal por meio do qual é julgado de seus crimes de guerra. O protagonista agora está isolado, mas a construção textual do jornal alemão o coloca em relação ao tribunal, partindo da figura do juiz e aportando na instituição julgadora. O fato de o L3 ser intitulado de "Saddam não comparece ao tribunal" novamente coloca o ex-ditador em destaque no hipertexto noticioso. Ao que o texto indica, Saddam ignora o fato de estar sendo julgado e, consequentemente, o FN faz uso disso para interpretar o fato. Não obstante, atrai o interlocutor de modo a recortar o ex-ditador como uma vítima que sabe dos crimes que cometeu, mas os nega até o fím.

No que concerne ao L4 "Iraque: tumulto e protesto no processo contra Saddam", outro referente é inserido na construção hipertextual dos sentidos. Deste modo, o povo iraquiano é referenciado de modo a legitimar as atitudes de Saddam, ou seja, noticiar que não é somente ele quem considera o julgamento inadequado, mas também parte dos cidadãos iraquianos. Além da contrariedade, estes protestam não somente de forma pacífica, mas também provocam tumultos. Observa-se, então, há uma continuidade de sentidos entre a proposição global da notícia e seus respectivos links. Retomando-se as considerações anteriores, o primeiro link trata da imposição do juiz Amin que parece estar em um duelo com o ex-ditador iraquiano; já o segundo link disponibiliza um vídeo que, pela construção do elo acessível, noticia a relutância do político em ser julgado; já o L3 reitera os sentidos do elo anterior. Este L4 coloca o referente em um contexto favorável a ele, ou seja, ao lado de seus seguidores, mas a proposição inicial colocada no título do hipertexto noticioso persiste, ou seja, de que o ex-ditador iraquiano não assume essa condição no tribunal, mas ainda conserva suas características tiranas. Vê-se que a figura de Saddam permeia todo o hipertexto noticioso, de modo não somente a noticiar o afastamento do juiz responsável pelo julgamento, mas também a circunscrever e contextualizar tal fato a partir de referências a ele feitas.

Efetuando-se um trabalho comparativo, vê-se que ambos os jornais fizeram usos de estratégias diferenciadas no que diz respeito à construção dos sentidos nos hipertextos noticiosos. O jornal brasileiro FO elencou o título sem nomes próprios, de modo a atrair o 
interlocutor a partir da suposição acerca de seu conhecimento prévio sobre o "ex-ditador do Iraque" e também sobre o que se tem passado com o mesmo. Não obstante, o jornal elencou um link que é considerado como um concentrador de textos a partir do uso de somente um referente, no caso, Saddam. Logo, depreende-se desta observação que a partir do título, no qual somente um dos referentes foi nominalmente elencado, o jornal brasileiro atrai o interlocutor de acordo com suas referências anteriores a respeito do processo, incluindo aí o juiz responsável pelo julgamento. A partir disso, construiu um link que remete o interlocutor a um sítio no qual se localizam inúmeras notícias que tenham o mesmo referente como protagonista. Desta feita, a FO optou por esboçar um único link que abrigasse outros links, já que ele não se configura como uma macroproposição, pois não concentra referentes, mas sim, apenas um. Apesar disso, observa-se que há uma continuidade de sentidos entre o título do hipertexto noticioso e o link, no qual há uma textualização mais específica dos referentes evocados quando do início do hipertexto noticioso. Há uma uniformidade semântico-textual entre ambos e, consequentemente, o link mostra-se como um operador de coerência, pois remete ao interlocutor às notícias interpretadas pelo jornal brasileiro. Por outro lado, o FN faz uso de uma série de links, no caso quatro, mas apenas três são estrategicamente construídos a fim de contextualizar o hipertexto noticioso. Ao contrário da FO, que se aproveita de um superlink, o FN mostra ao interlocutor o que é relevante para a leitura deste hipertexto noticioso, intercalando outros que permeiam a continuidade de sentidos no texto analisado. Assim, os quatro links perspectivam o ex-ditador iraquiano e o equivalem ora ao juiz Amin, ora à instituição julgadora. Considera-se, portanto, que há um equilíbrio, já mostrado no título, que é continuado na construção dos links. Especificamente com relação ao L4, o jornal alemão prima pela interpretação do fato a partir de protestos de iraquianos favoráveis à liberdade de Saddam Hussein. Assim, observa-se que o FN norteia sua interpretação para dois referentes fundamentais na sustentação de opiniões, no caso, o ex-ditador Saddam e o juiz Amin. Este jornal primou pela construção de links que remetem o interlocutor a outros hipertextos noticiosos e que já são observados quando da leitura do hipertexto. Trata-se, portanto, de demonstrar diretamente ao interlocutor que há outros fatos relacionados a este acontecimento, o que se torna uma ferramenta para manter o interlocutor no sítio e, além disso, sustentar valores e opiniões. 


\subsection{Análise de T8, T8.1 e T8.2}

O oitavo grupo de hipertextos noticiosos refere-se à morte de Johannes Rau, expresidente alemão morto em 2006. Dado que se trata de uma autoridade de origem alemã, espera-se que o FN trate o fato de maneira diferenciada se comparada a FO. Assim, aqui a questão da proximidade atinge um alto grau de importância, visto que os temas que orientam a produção dos hipertextos noticiosos estudados dizem respeito a somente um país, sociedade e cultura. Em vista disso, o jornal brasileiro pode evitar procurar fontes que o levem a tecer um hipertexto jornalístico semelhante ao alemão, já que não se trata de um acontecimento que mereça grande atenção por parte da editoria do jornal brasileiro. Por outro lado, para o FN a morte do ex-presidente representa um acontecimento histórico, que deve ser noticiado e que obteve grande atenção por parte da redação.

Iniciando a análise do hipertexto noticioso disponibilizado pela FO, nota-se que a proposição global "Ex-presidente alemão Johannes Rau morre aos 75 em Berlim" abarca o fato de modo a abordar as indagações quem, quando e onde, ou seja, por pouco não se tem a representação de um título. Em primeira instância, faz-se questão de ressaltar que o morto é um ex-presidente de origem alemã. Atribui-se relevância ao hipertexto noticioso, mesmo quando se trata de uma autoridade política européia. Desta feita, o campo inicial da frase é preenchido com a referência à posição máxima ocupada politicamente pelo indivíduo, de modo a encurtar as distâncias entre o acontecimento e o público-leitor do mesmo, no caso, o brasileiro. Assim, nota-se, primeiramente, que o jornal viu-se diante da necessidade de caracterizar o falecido de acordo com a história política em âmbito global e não apenas de acordo com seu nome. Faz-se referência à figura social de Rau. Adiante, observa-se o nome do ex-presidente alemão, posposto à sua caracterização. Consequentemente, a FO elabora uma proposição global que prima pela aproximação com o interlocutor brasileiro que poderia questionar: “Afinal de contas, quem é Johannes Rau?". Dando continuidade ao estudo do título, “[...] aos 75 em Berlim” é uma proposição que termina por configurar o processo de construção do referente no hipertexto noticioso. Com um dado acerca da idade e outro correspondente à idade na qual morreu o ex-presidente alemão, o jornal propõe uma categoria semântico-textual que prima pela elaboração geral da figura que veio a falecer, a fim de instruir o público-leitor nacional sobre o tema. Assim, em se tratando da proposição global do hipertexto noticioso disponibilizado pela FO, nota-se que a perspectiva dada ao 
acontecimento dá-se na moldagem da personagem política que estabelece uma relação com seu estado de vida atual. Desta maneira, parte-se de "Ex-presidente alemão [...]" e aporta-se em “[...] Johannes Rau morre aos 75 em Berlim” para que a construção de sentidos estabeleça uma relação de coerência com o conhecimento de mundo do público-leitor do jornal analisado. Para o jornal brasileiro, é mais relevante partir de uma ocupação política reconhecida em qualquer país ocidental do que da nominalização da personagem. Em termos de estratégia jornalística, a proposição "Ex-presidente alemão morre [...]" representa informação relevante e chamativa para os interlocutores do jornal.

No que diz respeito ao estudo dos links construídos pela FO, vê-se que há somente um link (L1) a ser seguido pelo interlocutor. Em termos quantitativos, este número não representa a diversidade informativa atribuída teoricamente ao hipertexto, ainda mais se considerada a natureza do hipertexto noticioso analisado. Desta maneira, somente um link representaria um link unidirecional (PRIMO \& RECUERO: 2000a), isto é, seria a única opção para o interlocutor. Entretanto, o link "Leia o que já foi publicado sobre Johannes Rau" reverte o aspecto quantitativo do hipertexto noticioso analisado. Observa-se que a construção da proposição que tem como substrato funcional direcionar o interlocutor a outro hipertexto noticioso é permeada de acordo com a referenciação à personagem do acontecimento. Desta feita, o jornal elaborou uma proposição semântico-textual que amplia o espectro temático. $\mathrm{O}$ que se vê é um estratégia de referenciação que parte de um acontecimento específico e aporta em uma proposição ainda mais global se comparada ao título do hipertexto noticioso. Consequentemente, a construção da coerência operada pelo link amplia os sentidos elaborados no título do hipertexto noticioso. Assim, parte-se da morte do ex-presidente alemão e aportase em todos os hipertextos noticiosos disponibilizados pela FO. A mesma vale-se das facilidades oferecidas pela tecnologia hipertextual, bem como da acessibilidade promovida pelo banco de dados eletrônicos. É uma tática concernente à manutenção dos interlocutores no sítio do veículo comunicativo. Apreende-se, portanto, que a partir da reconstrução de um determinado acontecimento, o jornal procura construir um referente de acordo com sua linha editorial a partir da elaboração de um link que redireciona o interlocutor a uma série de hipertextos noticiosos relacionados a um referente que é permanentemente ressignificado no hipertexto noticioso analisado.

Concentrando-se no hipertexto noticioso disponibilizada pelo FN, a proposição global "Ele queria reconciliar e não separar" é precedida pelo selo "Morre Johannes Rau". 
Subentende-se que esta última proposição advém de uma série de hipertextos noticiosos relacionados ao mesmo acontecimento e que mereceram uma atenção especial por parte da redação do jornal alemão. A primeira categoria observada neste hipertexto noticioso é a principal desencadeadora de esquemas de conhecimento que delimitam as fronteiras semântico-textuais a serem tecidas no decorrer da construção do texto. Desta maneira, a proposição global do hipertexto noticioso torna-se mais livre quando anteposta por uma categoria introdutória e, por isso, observa-se um título que é uma citação, visto que se encontra entre aspas. Tal citação é referente a uma caracterização de Rau feita por outrem. Apreende-se, portanto, que tanto a proposição anteposta quanto a posposta trabalham conjuntamente, assim como todo o hipertexto noticioso, de modo a sugerir ao interlocutor qual o assunto da notícia. Nota-se, portanto, que, além da menção à carreira política de Rau, as opiniões de outros políticos sobre o ex-presidente alemão também integram o hipertexto noticioso. A estratégia do jornal alemão reside no aproveitamento da tecnologia telemática em atualizar seu sítio eletrônico permanentemente, criando uma espécie de caderno especial somente com as notícias relacionadas à morte do ex-presidente alemão. Assim, "Morre Johannes Rau" não é somente uma categoria que tece os limites textuais, mas também propõe uma interação com o interlocutor a partir de uma construção textual iniciada pelo verbo "Morre [...]", a qual ativa conhecimentos que demarcarão as fronteiras lingüístico-textuais. Além disso, "Ele queria reconciliar e não separar" adverte o interlocutor de que se trata de um hipertexto noticioso que centraliza tematicamente as opiniões a respeito de Rau a partir de citações e experiências com outros políticos de tempos atuais e passados.

Com relação aos links disponibilizados pelo FN, observa-se em primeira instância um link que se encontra no nó do hipertexto noticioso alemão. Este link interrompe o excerto linear do hipertexto noticioso e abre uma espécie de "parênteses" no texto. O tema da proposição "Sobre as fronteiras partidárias, o político do Partido Social-Democrata foi aclamado com um grande homem de estado, quem muito agradeceu a Alemanha" concentrase na representação da figura política de Rau em linhas políticas gerais, ou seja, como os políticos de outros partidos viam o ex-presidente alemão. Com a transcrição do link "Políticos de todas as correntes entristecem-se por Rau", é possível analisar o processo de construção de sentidos em ambas as estruturas e verificar como a coerência é operada, mesmo se consideradas as estruturas de textos jornalísticos não-lineares. 
Com relação ao L1 elencado pelo FN "Políticos de todas as correntes choram por Johannes Rau", é observável que o referente relacionado ao ex-presidente alemão é ressignificado neste link inicial. Em evidência, os companheiros de profissão de Rau e pertencentes às mais diferentes linhas políticas recategorizam a construção de sentidos a ele concernente. Além de ser referenciado como um indivíduo que procurava sempre reconciliar e nunca separar, é novamente construído um referente que atende às características elencadas na proposição global do hipertexto noticioso. Consequentemente, políticos de linhas divergentes aglomeram-se e unem-se pela tristeza referente à morte de Rau. Se o ex-presidente alemão não obteve êxito em vida em suas tentativas de unificar as pessoas e a política, o fez quando da sua morte. Logo, "Políticos de todas as correntes [...]" foram os últimos indivíduos ou talvez os primeiros a serem reconciliados por Johannes Rau. No entanto, os políticos reúnemse com o objetivo de “[...] chorar [...]" pelo ex-presidente alemão recentemente falecido. Desta maneira, estabelece-se uma construção paradoxal concernente aos sentidos estabelecidos neste hipertexto noticioso analisado, já que todos se reconciliam momentaneamente para chorar por Rau. Fundamental também é observar a efemeridade estabelecida pela proposição, já que os políticos choram reconciliados pela morte de Rau, pois não o fizeram com fins políticos e, desta maneira, juntaram-se ao redor de um acontecimento efêmero. Após isso, voltarão a se digladiar nos assentos do parlamento alemão.

No que diz respeito ao L2, qual seja “Os presidentes da república: de Heuss a Köhler”, este recoloca Johannes Rau em sua posição política de maior prestígio e alinha o referente à lista de todos os presidentes da história da Alemanha. Desta feita, o ex-presidente alemão não é objeto de lamentos, mas faz parte do rol das autoridades políticas do país. Apreende-se, portanto, que a construção da coerência entre a proposição global deste hipertexto noticioso dá-se a partir da repetição de um mesmo referente, no caso, Johannes Rau. Assim, parte-se do homem que “[...] que queria reconciliar e não separar", passa-se pelo indivíduo que conseguiu unificar políticos de linhas divergentes e aporta-se no ex-presidente alemão alinhado a grandes políticos que ocuparam o posto mais importante no parlamentarismo, sistema de governo da Alemanha. Consequentemente, o processo de construção de sentidos neste hipertexto noticioso analisado dá-se por meio da recategorização referente a Rau através de proposições que funcionam como links. Não obstante, se considerada a proposição global "Ele queria reconciliar e não separar", novamente a interpretação deste L2 pauta-se pela reconciliação de todos os ex-presidentes alemães promovida pela morte de Rau. Observa-se, portanto, que a convergência semântico-textual, isto é, a centração temática por meio da 
recategorização e progressão referencial, é operada de acordo com a constante ressignificação de um referente que, enquadrado a partir de diferentes maneiras, faz com que o hipertexto noticioso tenha uma evolução no que diz respeito à informatividade. Desta feita, a construção dos links, além de promover a coerência no hipertexto noticioso analisado, incita a recategorização referencial que instiga o interlocutor a prosseguir com a leitura do hipertexto. No que concerne às estratégias jornalísticas, elencar dois links que ampliam o espectro informativo do texto significa informar o interlocutor de maneira mais ampla, o que aumenta o poder da voz da verdade do jornal. Além disso, elencar uma lista de ex-presidentes alemães é uma tática que visa resumir didaticamente a história política da Alemanha, o que pode atrair um número maior de interlocutores.

Efetuando um trabalho comparativo que visa observar as linhas gerais das análises de cada hipertexto noticioso, apreende-se que as divergências culturais orientam fortemente a construção da coerência em ambos os hipertextos noticiosos. Em primeira instância, o jornal FO difere do FN no que diz respeito à referenciação relacionada ao ex-presidente alemão Johannes Rau. Ao passo que a FO opta por uma proposição global que elenca "Ex-presidente alemão [...]", o FN recorreu a uma categoria que antecede o título e que ativa determinados esquemas de conhecimento, mas também com o intuito de destacar uma série de hipertextos relacionados à morte de Rau. Tal categoria não é observada no hipertexto noticioso produzido em português, já que pode ter sido a única referência feita pelo jornal ao acontecimento. Não obstante, o FN fez uso de uma citação relacionada a Rau, o que faz pressupor a delimitação semântico-textual proposta pela proposição global do hipertexto noticioso. Com relação aos links, a FO construiu, a partir da recategorização do referente "Johannes Rau”, um link que assume uma natureza de totalidade, já que propõe a leitura de todos os hipertextos noticiosos publicados no sítio jornalístico. Por outro lado, o FN elencou dois links que recategorizam o referente "Johannes Rau" de acordo com a construção de sentidos observada no título do hipertexto noticioso em alemão. No que diz respeito às estratégias jornalísticas de construção, observa-se que o jornal brasileiro elencou um link que pode vir a atrair o interlocutor a partir da disponibilização de todos os hipertextos noticiosos concernentes ao falecido ex-presidente alemão. Já o jornal alemão elencou dois links que promovem uma continuidade de sentidos se comparados à proposição global, expandindo o universo informativo do hipertexto e ressignificando o referente instantaneamente. 


\subsection{Análise de T9, T9.1 e T9.2}

O nono grupo trata dos conflitos ideológico-sociais presentes no Oriente Médio. Tratase de um acontecimento noticiado por ambos os jornais e que relata a acusação por parte do ministro de Israel contra Irã e Síria por atentados que provocaram a morte de 26 pessoas em Tel Aviv. Tal temática concretiza diferentes posicionamentos de natureza social, histórica e política, retomando-se os pressupostos de Esser (1998), e que podem ser revelados quando de uma análise contrastiva entre textos em alemão e em português. O Brasil, por ser um país que foi destino da imigração síria e, consequentemente, por abrigar um grande número de sírios, pode vir a ser um fator de influência. Ademais, o Irã é um país que tem levantado inúmeros questionamentos com relação à sua política armamentista de enriquecimento de urânio.

Dando início à análise do hipertexto noticioso da FO, a proposição global "Ministro de Israel acusa Irã e Síria de financiar atentados" traz revelações concernentes à construção dos sentidos neste hipertexto noticioso. Nota-se a presença de três referentes que, quando colocados em eixo linear, polemiza o texto. Desta maneira, "Israel", "Irã" e "Síria" formam um grupo de discórdia, visto que os dois últimos são similares ao menos nas questões político-sociais. Por outro lado, nota-se que "Ministro de Israel" é uma figura política importante do país judeu que faz a acusação, tornando-a mais autoritária. Assim, a acusação parte de uma personagem política e está direcionada a dois países muçulmanos que ocupam a posição de réus quando da tessitura do título. Observa-se o jogo de forças empreendido pelo jornal não somente através do viés da informação nova, a qual "Ministro de Israel acusa [...]", mas também pela especificidade na qual é feita a acusação. Nota-se também que Irã e Síria são acusados em sua totalidade, ao passo em que o acusador é uma figura política de Israel. Os três referentes combinados ao referente "atentados" permite observar que as posições por eles ocupadas influenciam na construção de sentidos no título analisado.

Referente à análise dos links, dois foram elencados pela FO. Ambos localizam-se abaixo de um categoria textual denominada "Especial", que procura indicar ao interlocutor que se tratam links diferenciados por terem sido elaborados a partir de um esforço maior por parte da redação. Consequentemente, trata-se de links que se dirigirão a um sítio eletrônico que ou apresentará um complexo de reportagens especiais ou uma série de hipertextos noticiosos que se relacionam de acordo com os principais referentes do hipertexto analisado. Assim, a FO 
inclui no espectro hipertextual uma seção que procura abrigar todo o hipertexto noticioso. Apreende-se, portanto, que o hipertexto noticioso analisado preconiza, além de uma nãolinearidade técnica, uma não-linearidade textual, pois parte de um texto mais específico a fim de indicar ao interlocutor a existência de uma página eletrônica, localizada no sistema hipertextual do jornal, que abriga reportagens especiais e diferenciadas.

O L1, qual seja "Leia cobertura completa sobre conflito no Oriente Médio", faz uso de um referente que recategoriza os três países referenciados quando da tessitura da proposição global. Desta feita, “[...] Oriente Médio" recategoriza os referentes, de modo a possibilitar a colocação de informações novas relacionadas não ao texto em si, ou seja, à construção de sentidos, mas ao que a FO elaborou para seu público-leitor. Ressalta-se que a categoria "Especial" também é ressignificada a partir do referente "[...] cobertura completa [...]", advertindo o interlocutor acerca dos esforços empreendidos pela redação no sentido de designar uma equipe de jornalistas especialmente voltada para a cobertura dos conflitos no Oriente Médio. Entretanto, disputas territoriais e políticas nessa região surgiram desde a criação do estado de Israel, em 1948. Assim, apreende-se que o conflito no Oriente Médio ao qual se refere a FO trata da questão armamentista provocada pelo enriquecimento de Urânio iraniano. O jornal atualiza um referente de modo a construir um link que adverte o interlocutor de uma cobertura completa sobre o assunto. No que diz respeito à característico jornalística residente neste tipo de link, anota-se que o fato de a FO elaborar um link que diz "Leia tudo sobre [...]" procura totalizar as possibilidades de procura informativa por parte dos interlocutores.

O L2 "Leia o que já foi publicado sobre o programa nuclear iraniano", a exemplo do primeiro link, faz uso de um referente proposto no título do hipertexto noticioso, no caso, “[...]Irã [...]”. A partir dele, insere-se no espectro hipertextual um link que discorre acerca do "[...] programa nuclear iraniano", fazendo com que o fato de ter havido um atentado em alguma cidade israelense esteja relacionado aos investimentos tecnológicos iranianos. De acordo com a observação acerca da proposição global do hipertexto noticioso e deste L2, elencado sob a categoria "Especial", ressalta-se que dois hipertextos noticiosos que, aparentemente, não tem relação factual, são conjugadas a partir da construção de sentidos e, consequentemente, da uniformidade dos mesmos. Tal progressão temática dá-se de acordo com a recategorização de referentes, obtendo-se coerência entre as diferentes partes do hipertexto. A estratégia jornalística observada na construção deste link é a mesma notada no 
primeiro link, ou seja, a tentativa de esgotamento a partir da disponibilização do banco de dados da FO.

Dando continuidade ao estudo contrastivo deste grupo, o hipertexto disponibilizado pelo jornal FN tem início com uma categoria anteposta à proposição global, o selo. "Oriente Médio" é a informação primeira encontrada neste hipertexto noticioso e trata-se um tema global que procura já contextualizar o hipertexto analisado. Assim, é um referente de natureza geral quando observados os sentidos desdobrados no título e nos links, tendo a função de ativar conhecimentos que possibilitem a criação de barreiras limítrofes concernentes ao aspecto semântico-textual do hipertexto noticioso.

O título "Mofaz: atentado foi obra de Irã e Síria", se analisada detidamente, mostra algumas considerações a respeito da construção de sentidos no jornal FN. Assim, o título tem início com "Mofaz [...]", uma personagem desconhecida no hipertexto, mas que é alvo de pressuposições por estar relacionada a "Oriente Médio". Faz-se uso de um sinal de dois pontos para que uma informação de destaque seja introduzida no espectro hipertextual. Ainda com relação ao hipertexto noticioso em alemão, o referente acusa dois países de maioria muçulmana de atentados em alguma localidade israelense. Opera-se uma construção de sentidos que coloca em evidência uma autoridade de Israel que dirige acusações a dois países em totalidade. Desta maneira "[...] atentado foi obra de Irã e Síria" complementa o sentido do campo inicial da proposição e, por isso, a explicitação de um sinal de dois pontos procura economizar, em termos textuais, o título do hipertexto noticioso estudado. Tal construção semântico-textual é mais carregada de sentidos se comparada a uma outra maneira de se elaborar a categoria que antecede o nó e os links do hipertexto, como "Mofaz diz que atentado foi obra de Irã e Síria”.

Concernente ao estudo dos links, observa-se que o FN elencou apenas um link, o L1 "Feridos no atentado à estação de ônibus em Tel Aviv". Como estratégia de progressão temático-textual, nota-se que a repetição do referente "[...] atentado [...]" delimita-o de modo a possibilitar ao jornal a inserção de uma informação que procura complementar aquela lida pelo interlocutor. Entretanto, a temática da proposição global aloca-se no aspecto político do atentado. Já neste L1 as atenções concentram-se na interpretação do fato em si e em suas conseqüências físicas. Desta maneira, o primeiro referente observado é "Feridos [...]", o que mostra a inclinação do FN para outro aspecto interpretativo do acontecimento. Insere-se neste 
link a especificação do local do atentado que gerou a discussão política e, mais, acusação do referente "Mofaz" contra os países Irã e Síria.

Efetuando-se um trabalho comparativo entre os hipertextos noticiosos veiculados pelos jornais FO e FN, ressalta-se que, em primeira instância, a proposição global do texto em alemão é econômica com relação ao título construído pelo jornal brasileiro. Referente aos links, a FO optou por ressignificar dois referentes trabalhados no título da notícia e, consequentemente, construiu links que procuram totalizar as possibilidades de procura no sistema hipertextual do próprio jornal. Sob a égide "Especial", estes links destacam-se no hipertexto noticioso não somente por se tratarem de aspectos essenciais, mas também por estarem indicados através de marcadores que revelam empreendimentos diferenciados por parte da redação do jornal. Já no hipertexto do FN, houve a necessidade de se recategorizar um referente do título por meio da repetição, possibilitando assim a inserção de hipertexto noticioso paralelo ao hipertexto analisado, expandindo o universo informativo do interlocutor.

\subsection{Análise de T10, T10.1 e T10.2}

O último grupo de hipertextos noticiosos a serem comparados nesta pesquisa trata das divergências diplomáticas que envolvem Estados Unidos e Irã. Apesar da disputa se dar entre ambas as nações, o assunto teve sua discussão ampliada no momento em que Angela Merkel, primeira ministra alemã, fazia visita oficial ao presidente americano. Assim, o papel políticomilitar alemão, além da campanha contra o terrorismo liderada pelos yankees, pode trazer à tona semelhanças e diferenças no que diz respeito à construção de sentidos, bem como referentes às estratégias jornalísticas. Ressalta-se que os hipertextos noticiosos selecionados para análise apresentam, em primeira instância, temas divergentes. Entretanto, estas temáticas assemelham-se à medida que o hipertexto noticioso é desenvolvido.

Iniciando pelo texto da FO, a proposição global “Bush diz que há 'obrigação' de impedir que Irã tenha armas nucleares" elenca como referente inicial "Bush [...]". Tal desencadeia uma série de conhecimentos e aliado a "[...] diz que há 'obrigação' [...]" revela um certo caráter de autoritarismo por parte do líder político americano. O uso das aspas em “obrigação" pressupõe que a utilização do termo foi feita pelo próprio presidente, atribuindo- 
se a ele a responsabilidade do uso. Assim, o jornal brasileira remete a necessidade de se impedir que algum outro país tenha armas nucleares à voz daquele que a exprimiu. Não obstante, "[...] de impedir [...]" reforça a hipótese da unilateralismo empreendida no início deste estudo, visto que o termo "obrigação" promove a continuidade de sentidos por meio do verbo utilizado. Ora, tal elaboração semântico-textual leva a interpretações que permitem a afirmação de que os desejos do americano soem antidemocráticas e, consequentemente, tiranas. É crucial ressaltar que "Bush diz que há 'obrigação' de impedir [...]” ocupa a posição inicial do título, propondo que o ineditismo localiza-se no aspecto unilateral do discurso de Bush, ao passo que a questão que deveria ser mais problemática, no caso "[...] que Irã tenha armas nucleares", torne-se um lugar comum perto da declaração do presidente. Desta forma, o hipertexto noticioso ganha relevância, advertindo o interlocutor de que há novas com relação ao tema.

No que diz respeito ao estudo links, notam-se duas categorias nas quais os links foram alocados: "Leia mais" e "Especial". A primeira diz respeito à organização e seleção de hipertextos noticiosos relacionados ao tema, elencado links que obedecem a uma cronologia de disponibilização. A segunda categoria refere-se a uma cobertura especial do acontecimento, fazendo pressupor que jornalistas foram designados de se ocuparam somente de fatos relacionados ao hipertexto noticioso. Provavelmente hipertextos noticiosos diferenciados são, nesta seção, oferecidos ao interlocutor.

O L1 "Irã levaria anos para ter a bomba, dizem especialistas" reitera um dos referentes trabalhos quando da confecção da proposição global do hipertexto noticioso, apreendendo-se, portanto, uma continuidade de sentidos. A partir disso, o texto passa a discorrer acerca da possibilidade de o país islâmico ter uma bomba atômica de acordo com a opinião de especialistas no assunto. Desta feita, o início do hipertexto noticioso, o qual está focalizado na opinião do presidente americano a respeito da política armamentista do Irã, é ampliado de modo a inserir no espectro hipertextual um outro hipertexto noticioso que trata de um assunto que se intersecciona com o hipertexto analisado, relembrando o fator de mobilidade de centros colocado por LÉVY (1999) e aproveitado por Marcuschi (2000). Nota-se, portanto, que a notícia, originada da opinião de Bush, é cruzada pela avaliação da capacidade iraniana de criar uma bomba atômica, revelando-se uma soma de informações enquadradas na perspectiva da empreso jornalística. Assim, o potencial telemático da Internet é aproveitado pela FO, de modo a alinhar hipertextos informativos oriundos de seu próprio banco de dados. 
Pode-se interpretar o hipertexto noticioso analisado e o primeiro link elencado como contraditórios, já que a proposição global do texto afirma que Bush vê a necessidade de impedir que o Irã venha a ter uma arma nuclear; já o L1 traz a opinião de técnicos baseados no estágio atual de tecnologia no Irã, os quais defendem que isso levaria anos para acontecer. Por outro lado, se se tomar estes dois aspectos do hipertexto analisado como coerentes, vê-se que a ressignificação de "Irã" tem como função precípua corroborar a opinião do presidente americano, admitindo nas entrelinhas que a autoridade política tem razões ainda não reveladas pelas quais critica o país localizado no Oriente Médio.

"Leia o que já foi publicado sobre o programa nuclear iraniano" é o segundo link disponibilizado pela empreso jornalística brasileira. Ligando-se à proposição global este L2 confecciona um todo coerente interligado por meio de proposições consideradas fundamentais no hipertexto, como "Bush", "Irã" e "nuclear". Assim, a FO reúne todos os hipertextos noticiosos relacionados ao tema e as disponibiliza ao interlocutor em decorrência do sistema de banco de dados do jornal. Dessa forma, o espectro informativo do hipertexto noticioso prioriza a discussão acerca do potencial nuclear iraniano, apesar de ter noticiado o ponto de vista do presidente americano, o qual governa um país politicamente antagônico à nação muçulmana.

Empreendendo-se uma observação minuciosa no hipertexto noticioso do FN, nota-se, em primeira instância, a divergência de enfoques dos jornais. Destaca-se, portanto, o selo do hipertexto noticioso, o qual é intitulado "Chanceler na Casa Branca". Como já colocado, o selo é um recurso referente à técnico jornalística de intitular uma série de notícias oriundas a partir da repercussão de um mesmo fato dada pela empreso jornalística. Logo, como se trata da visita da primeira-ministra alemã aos Estados Unidos, potência mundial, tal acontecimento mereceu a atenção por parte do FN e, apesar de essa ser o único hipertexto noticioso concernente a este fato que será aqui analisada, o uso do selo comprova tal afirmação. A partir dele, pode-se antever como o texto será tecido e quais serão os sentidos textualmente construídos pelo jornal. Adiante, "Bush com tempo e elogio para Merkel” é a proposição global do jornal online alemão. Nota-se que que as duas personagens do texto encontram-se em posições extremas na proposição, visto que a referência ao presidente americano está localizada no início do título do hipertexto noticioso. Uma das possíveis interpretações para o título é a atenção dada por Bush a Merkel, atribuindo à referência ao norte-americano como fundamental para perspectivizar o acontecimento de acordo com a linha interpretativa do 
jornal. Aliado a isso, a importância social dada ao presidente americano, visto que é ele quem se dirige à primeira ministra alemã, de acordo com o jornal europeu. Não o suficiente, a preposição "para” fortalece as afirmações acima tecidas.

Discutindo-se o L1 disponibilizado pelo FN "Vídeo: Bush e Merkel querem resolver o conflito do Irã diplomaticamente", observa-se a possibilidade de intersecção de diferentes linguagens em suporte eletrônico. Assim, "Vídeo" adverte o interlocutor de que ele pode se informar não somente por meio de textos, mas também através de imagens, assemelhando-se aos recursos operados pelas redes de televisão. Adiante, vê-se novamente os dois personagens da notícia já citados quando da confecção da proposição global do hipertexto noticioso. A partir disso, insere-se no espectro hipertextual uma informação que não foi citada quando do selo e do título do hipertexto noticioso, qual se refere à insatisfação americana com relação à política bélica do Irã. De acordo com uma proposição global que se concentrou na referência a Bush, vê-se neste link que a operação dá-se através da referência a ambos. A partir de uma suposta pressuposição feita pelo interlocutor sobre os termos "Casa Branca" e "Bush", podese inferir que a vista da chanceler alemã trataria do tema elencado neste link.

Já o L2 veiculado pelo FN trata da viagem de Merkel para os Estados Unidos, discorrendo sobre o contexto no qual foi convidada para visitar o presidente americano. "A viagem de Merkel para Washington: "como convidada por amigos"”. Depreende-se desta proposição que a ida da política alemã deu-se em clima amistoso e descompromissado. No entanto, se efetuada uma comparação com o primeiro link, vê-se que, apesar de o convite ter sido feito nestes moldes, a temática tratada nada tem de amistosa ou referente a amizades. Assim, afirma-se que o FN faz uso das aspas exatamente em razão da ironia, já que Bush procura apoio internacional a fim de combater uma possível produção de armas nucleares no Irã. Fundamental é observar o jogo de sentidos operado pelo jornal, em razão do uso de proposições que compõem um todo heterogêneo, mas que se minuciosamente analisado, revela que Merkel foi amistosamente convidada. Por outro lado, vê-se que "amigos" foi utilizado em termos políticos e não pessoais. Desta feita, a amizade é necessária, já que a paz mundial depende destes convites. Assim, a empreso jornalística insere uma informação relacionada à excursão política de Merkel.

No que diz respeito ao L3 "Merkel deve convencer Bush a fechar Guantánamo", nota-se novamente a utilização da referência aos dois personagens principais do acontecimento. 
"Merkel" e "Bush" encontram-se novamente em posições díspares, ao contrário do que aconteceu no L2, no qual ambos encontram-se no mesmo lado para atuar como força de paz para o mundo. Agora, diferentemente do título do hipertexto noticioso, é a vez de Merkel ocupar a posição inicial da proposição, relatando-se, portanto, os interesses da chanceler alemã na vista aos Estados Unidos. Adiante, insere-se uma informação que também poderia ser fruto de pressuposição por parte do interlocutor, já que a base de prisioneiros em Cuba tem sido alvo de discussão por políticos de todo o mundo, sendo que muitos deles condenam sua existência. Logo, “[...] 'como convidada por amigos"”, inicialmente utilizada de acordo com o recurso da ironia é transferida à referência a Merkel, colocando que, apesar das atribulações políticas, a alemã não foi somente ouvir, mas também propor determinadas soluções. Além disso, a superpotência americana não necessidade de ajuda, mas sim de apoio da comunidade internacional e consenso de opiniões.

Comparando-se os dois hipertextos noticiosos, destaca-se a divergência de enfoques entre os dois jornais, revelando o caráter de proximidade de ambos. A FO concentrou-se na afirmação de Bush relacionada à tentativa de impedimento de o Irã ter armas nucleares por parte de todas as nações, como que conclamando por auxílio internacional. Adiante, com a disponibilização de dois links abrigados sob as categorias "Leia mais" e "Especial", o jornal interpreta o fato como precipitado, pois insere no espectro informativo a incapacidade momentânea de o país islâmico ter uma ogiva nuclear. Já o FN dá destaque à visita da chanceler alemã Angela Merkel, colocando-a inicialmente como convidada. A análise da coerência operada entre o título e seus respectivos links mostra que o texto é irônico, principalmente se observado o L2 e que o papel da proposição "Merkel” passa de passivo e ativo, levando-se a entender a visita como uma troca de idéias a respeito de temas diversificados. A função dos links nos dois hipertextos noticiosos analisados é, além de promover a continuidade de sentidos entre o título e os links, mostrar como os próprios jornais fazem uso da tecnologia hipertextual a fim de promover o fato como uma notícia. A partir da ancoragem de determinados referentes, tanto a FO como o FN ampliam o texto linear representando no nó e expandem o hipertexto noticioso, fazendo do referente um elemento textual que orienta a ligação entre dois hipertextos. Desta maneira, não se trata somente de uma ferramenta técnica, mas também textual, já que realiza a intermediação entre duas macroestruturas (van DIJK: 2002) que devem se encontrar em algum ponto. Este encontro é planejado exatamente pelo jornal, a fim de que os conhecimentos ativados na mente dos interlocutores dirijam-se gradativamente àquilo disponibilizado na forma de link. 


\section{Os quadros hierárquicos das respectivas análises 4.1. Quadros de T1, T1.1 e T1.2}

Figura 1: FO

T: Bachelet será a $1^{\mathrm{a}}$ mulher a governar o Chile

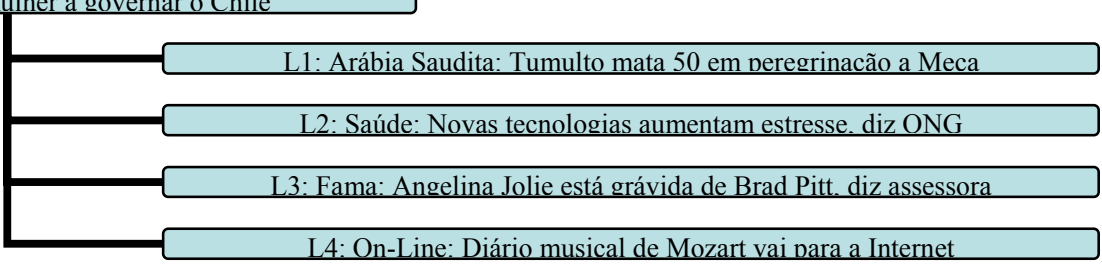

Figura 2: FN

T: Socialista Bachelet é a primeira presidente do Chile

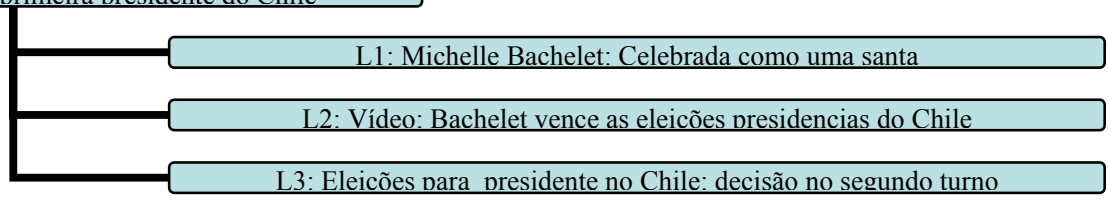

\subsection{Quadros de T2, T2.1 e T2.2}

Figura 3: FO

\section{T: Ataque suicida no Afeganistão deixa 20 mortos}

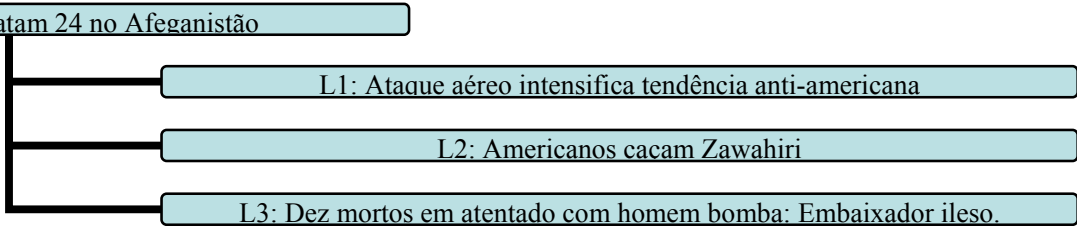




\subsection{Quadros de T3, T3.1 e T3.3}

Figura 5: FO

\section{T: Chávez comemora vitória com ampla vantagem}

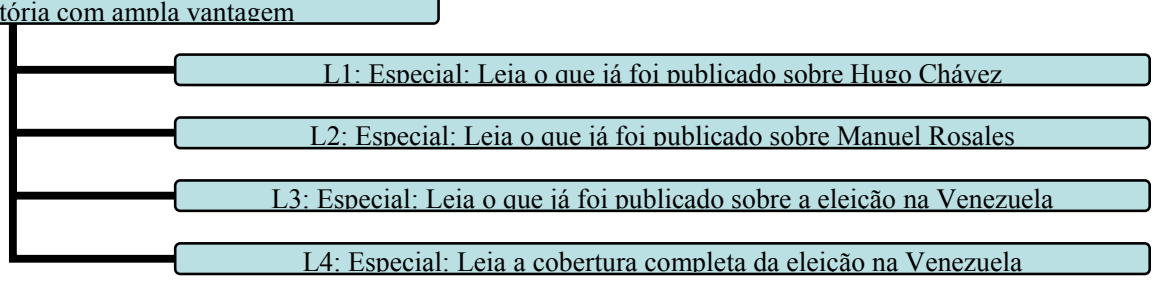

Figura 6: FN

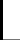

L1: Presidente Chávez na Venezuela antes da reeleicão

L2: Hugo Chávez e "amigos": União contra Washington

L3: Equador: Correa vence eleicões presidenciais

\subsection{Quadros de T4, T4.1 e T4.2}

Figura 7: FO

T: Ex-presidente alemão Johannes Rau morre aos 75 em Berlim

L1: Leia o que iá foi publicado sobre Johannes Rau

Figura 8: FN 


\subsection{Quadros de T5, T5.1 e T5.2}

Figura 9: FO

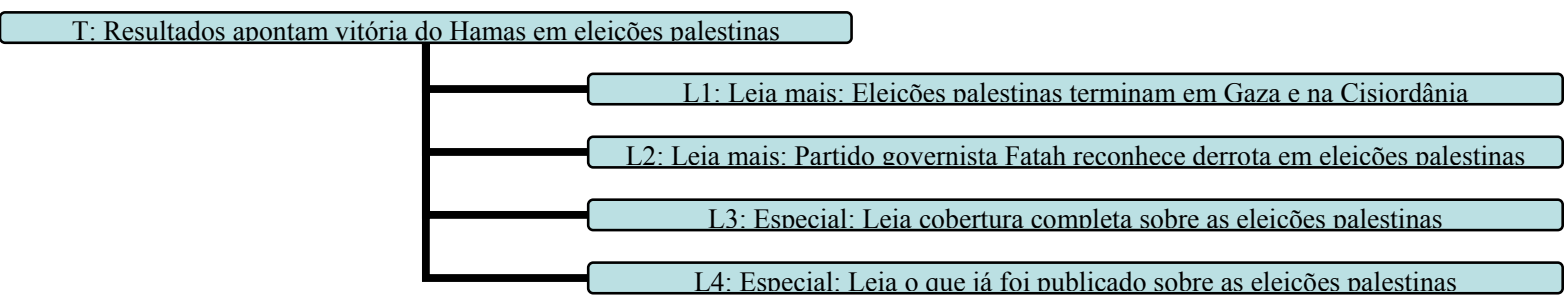

Figura 10: FN

T: Depois da vitória do Hamas o governo Fatah sai de cena na Palestina

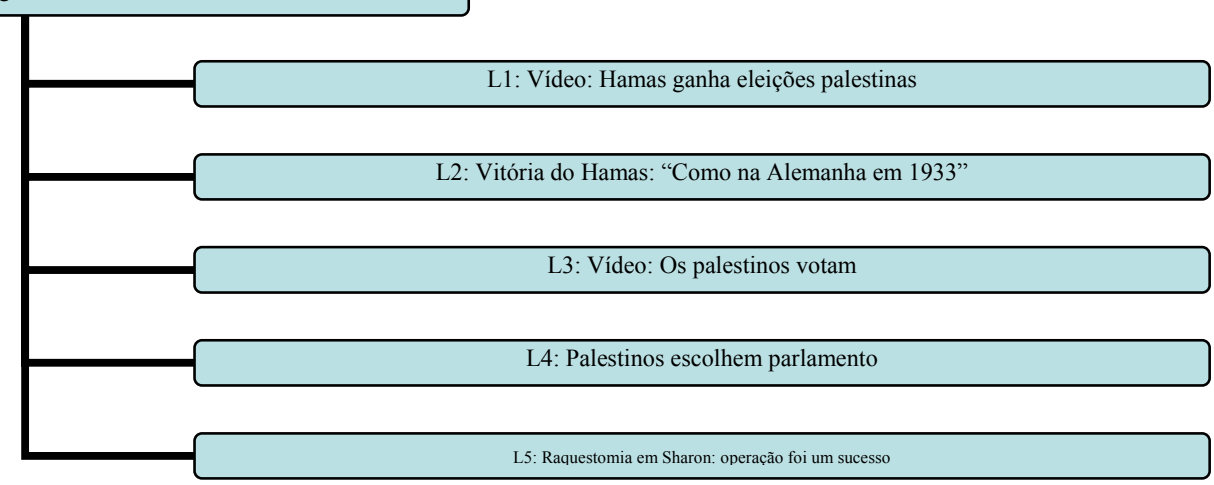




\subsection{Quadros de T6, T6.1 e T6.2}

Figura 11: FO

T: Juiz do ex-ditador do Iraque apresenta carta de renúncia

L1: Especial: Leia o que iá foi publicado sobre o iulgamento de Saddam Hussein

Figura 12: FN

T: Juiz responsável no processo contra Saddam renuncia

L1: Processo contra Saddam: Juiz Amin impõe-se

\subsection{Quadros de T7, T7.1 e T7.2}

Figura 13: FO

T: Líderes se reúnem em Londres para discutir crise com Irã

L1: Especial: Leia o que iá foi publicado sobre a crise nuclear iraniana

Figura 14: FN

T: Crise Nuclear. Chefe da AIEA não descarta violência contra o Irã

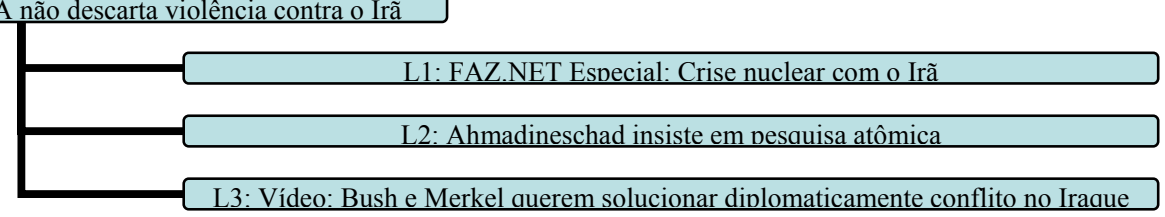




\subsection{Quadros de T8, T8.1 e T8.2}

Figura 15: FO

T: Ministro de Israel acusa Irã e Síria de financiar atentados

L1: Especial: Leia cobertura completa sobre conflito no Oriente Médio

L2: Especial: Leia o que iá foi publicado sobre o programa nuclear iraniano

Figura 16: FN

T: Oriente Médio. Mofaz: atentado foi obra de Irã e Síria

L1: Feridos no atentado à estacão de ônibus em Tel Aviv

\subsection{Quadros de T9, T9.1 e T9.2}

Figura 17: FO

T: Alianca xiita vence eleicões parlamentares no Iraque

L1: Especial: Leia cobertura comnleta sobre as eleicões parlamentares no Iraque

L2: Especial: Leia o que iá foi publicado sobre eleicões parlamentares no Iraque

Figura 18: FN

T: Resultado das eleicões no Iraque: Xiitas não conseguem maioria absoluta

L1: Especial FAZ.NET: Eleicão no Iraque 


\subsection{Quadros de T10, T10.1 e T10.2}

Figura 19: FO

T: Bush diz que "há" obrigacão de impedir que Irã tenha armas nucleares

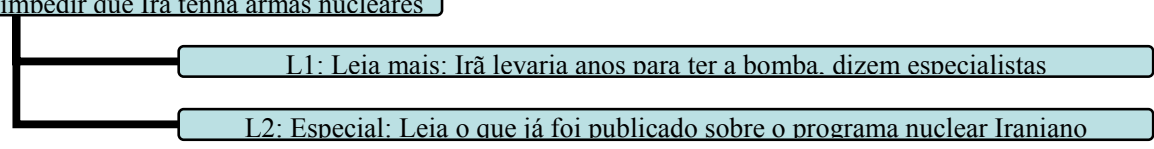

Figura 20: FN

T: Chanceler na Casa Branca: Bush com tempo e elogio para Merkel

L1: Vídeo: Bush e Merkel auerem resolver conflito do Irã diplomaticamente

L2: A viagem de Merkel para Washington: como convidada por amigos

L3: Merkel deve convencer Bush a fechar Guantánamo 


\section{Discussão dos resultados}

Os resultados obtidos a partir da análises contrastivas dos links serão distinguidos, primeiramente, de acordo com os aspectos textuais e, posteriormente, decorrentes de observações feitas no âmbito jornalístico.

As dez análises empreendidas no jornal brasileiro $\mathrm{FO}$ e no alemão $\mathrm{FN}$ mostraram que todos os hipertextos noticiosos foram construídos com links elaborados a partir de um referente explícito na proposição global (van DIJK: 2002), com exceção de apenas um disponibilizado pela FO. Desta maneira, detectou-se a ressignificação de referentes presentes nos títulos dos hipertextos noticiosos. Isso revela que os links podem ser considerados elementos de coerência no hipertexto noticioso, levando-se a crer que não são formatados aleatoriamente, mas sim, a partir de referentes textuais que possibilitam a ligação com outro hipertexto noticioso e que, consequentemente, relaciona-se ao acontecimento noticiado. Entretanto, a condição observada não revela, por ora, quais foram os processos de coerência utilizados pelos jornais FO e FN.

Apenas um hipertexto noticioso observado na FO não disponibilizou links construídos a partir de referentes presentes em sua proposição global, mas links que integrassem o hipertexto noticioso analisado a outros presentes no banco de dados do jornal brasileiro. $\mathrm{O}$ conceito de hipertexto não se deve basear somente na existência de dois fatores, quais sejam, nós e links, mas também na observação destes links. Os links analisados neste hipertexto noticioso não se destacam como operadores de coerência textual, mas sim, como ferramentas de coerência de design (STORRER: 2002), isto é, contribuem estruturalmente para a existência deste gênero discursivo inédito. Desprovido de coerência textual, ou seja, sem um dos fatores de textualidade colocados por de Beaugrande \& Dressler (1981), não se considera aqui este hipertexto noticioso analisado como um hipertexto, mas como um hipertexto noticioso elaborado a partir do processo de digitalização elencado por Moreira (2003).

Dos nove hipertextos noticiosos que apresentaram links construídos a partir da ressignificação de referentes presentes nas proposições globais na FO, seis hipertextos noticiosos da FO revelaram a repetição na construção do link, ou seja, 66,6\%. Por outro lado, dos dez hipertextos noticiosos do FN, - visto que todos disponibilizaram links coerentes com a 
proposição global, - sete foram elaborados desta forma no jornal alemão FN, totalizando $70 \%$. No que diz respeito ao número de hipertextos que contêm links produzidos a partir da repetição, nota-se que as porcentagens são aproximadas, podendo-se afirmar que a minoria dos hipertextos noticiosos analisados nesta pesquisa prescindem da repetição de referentes presentes nas proposições globais. No entanto, como cada hipertexto noticioso disponibiliza um número divergente de links, é necessário que estas comparações sejam trabalhadas minuciosamente, ou seja, de acordo com o número de links.

No que diz respeito ao número de links construídos a partir da repetição de referentes, calcula-se, em primeira instância, a quantidade de links disponibilizada por cada jornal. Os hipertextos noticiosos veiculados pela FO contêm 22 links, ao passo em que o FN elencou 28. Dos 22 links disponibilizados pelo jornal brasileiro, 10 foram construídos a partir da repetição, isto é, 45,4\%. Dos 28 links do FN, 16 foram construídos a partir da repetição de referentes presentes nos títulos dos hipertextos noticiosos, ou seja, 57,4\%. Na FO, o uso da repetição deu-se em quase $50 \%$ dos links, ao passo em que no $\mathrm{FN}$, a porcentagem atingiu aproximadamente $60 \%$, ou seja, mais que a metade. Logo, nota-se que o processo de construção do link, tanto no jornal brasileiro quanto no jornal alemão, ocupou mais que $50 \%$ do total de links analisados nesta pesquisa. Pode-se afirmar, portanto, que a produção do link no hipertexto noticioso dá-se, em parte, pela continuidade de sentidos por meio da repetição de elementos semanticamente relevantes, mantendo-se um centro temático, o que faz dos textos do corpus analisado lineares no aspecto textual-discursivo.

Viu-se que a repetição, como uma das estratégias de referenciação, é largamente utilizada pela FO. Portanto, a repetição

"[...] assume um variado conjunto de funções. Contribui para a organização discursiva e a monitoração da coerência textual; favorece a coesão e a geração de seqüências mais compreensíveis; dá continuidade à organização tópica e auxilia nas atividades interativas. Disso tudo resulta uma textualidade menos densa e maior envolvimento interpessoal, o que torna a repetição essencial nos processos de textualização [...]" (MARCUSCHI, cit. por KOCH, 2004, p. 111-112).

Além disso, o uso da repetição como estratégia de referenciação textual em hipertextos noticiosos demonstra uma categorização em conjunto com as características técnicas do suporte telemático, contrariando as afirmações de Lévy (1999) acerca da mobilidade de centros. A continuidade de sentidos concretizada na construção dos links não possibilita aos 
interlocutores alteração na rede semântico-discursiva sugerida pela proposição global do hipertexto noticioso. Apesar de tecnicamente não-linear, o estudo deste corpus mostrou que a centração de elementos relevantes é pertinente no suporte da Internet, de modo que o hipertexto é estruturalmente seccionado em links que reiteram determinados referentes presentes nos títulos. São espécies de rasgos (LÉVY: 1999) promovidos pelo jornal, que atuam como operadores de coerência, pois enquadram um referente da proposição global do hipertexto noticioso.

Com relação às categorias "Especial", observadas tanto na FO quanto no FN, elas aparecem em quase todos os hipertextos noticiosos do jornal brasileiro. Dos 22 links analisados no jornal FO, quatorze surgem após a categoria "Especial”, ou seja, 63,6\%. Já no FN, dos 28 links estudados, apenas dois estão em condição igual aos quatorze vistos no jornal brasileiro, isto é, 7,14\%. Em vista desta divergência, surge a problemática do que vem a ser uma seção considerada "Especial". Faz-se necessário observar como os links destas categorias são construídos.

Dos quatorze links da FO alocados na categoria "Especial", oito foram construídos a partir da repetição de elementos observáveis nas proposições globais, ou seja, 57,14\% dos links na seção "Especial” do jornal FO contêm referentes já citados nos títulos dos hipertextos noticiosos. Já no alemão FN, dos dois links na seção "Especial”, os dois reiteram referentes do título, ou seja, 100\%. Constata-se, portanto, uma divergência de 50\% no uso da repetição para a elaboração de links inseridos nas categorias "Especial". Neste caso, o jornal alemão destaca a sua seção a partir da repetição de referentes, fazendo uso de outras estratégias de progressão textual, no caso, aqui englobadas no conceito de referenciação.

Assim, a repetição observada nestes hipertextos ressignifica o referente proposto no título de maneira a sugerir ao interlocutor de que é possível acessar um banco de dados ou memória (PALÁCIOS: 1999) com hipertextos noticiosos relacionados àquele referente. Tratase de uma progressão hipertextual que tem um nó de ancoragem e um nó de destino configurado de acordo com um sem-número de hipertextos noticiosos organizados pelos jornais. O papel do link é, parcialmente, repetir um referente de destaque para a tessitura do link, de modo a resgatar outros hipertextos noticiosos presentes no banco de dados. 
A construção da coerência e a repetição observadas nas análises contrastivas operam entre macroproposições e links. Notou-se que as categorias atuam de acordo com referentes que são referenciados ou reiterados alternativamente. Essa mutualidade constrói uma uniformidade de sentidos entre aquilo que está no nó e fora dele. Desta forma, sugere-se aqui uma modalidade de coerência não prevista nas classificações de $\mathrm{KOCH}(2003,2004)$. A razão é o link encontrar-se fora da linearidade hipertextual, representada pelo nó, visto que somente um link foi encontrado no nó de um hipertexto noticioso.

Quando não repetidos, nota-se que são objeto de referenciação, o que também possibilita inserir outros hipertextos noticiosos. De acordo com a ativação de estruturas de conhecimento, o link passa a ser um fator de construção da coerência, mas destacado da linearidade do título e do nó. Essa forma foi amplamente observada no jornal alemão e pouco utilizada na FO. Ainda com relação à repetição, ela encontra-se no FN abrigada na categoria "Dossiê". A FO também fez uso da referenciação, mas somente em links localizados abaixo de outros que foram construídos a partir da repetição.

Analisando-se os links elaborados de acordo com o processo de referenciação, a FO apresentou uma porcentagem de 54,6\%, ao passo que o FN totalizou 42,6\%. Consequentemente, nota-se que o jornal brasileiro faz mais uso da referenciação, ou seja, na maioria das vezes não repete os referentes observados nos títulos dos hipertextos noticiosos, ao contrário do jornal alemão, que dentre os dez hipertextos analisados, fez uso da repetição em menos da metade deles. Apreende-se deste cálculo que a construção da coerência através da referenciação nos hipertextos noticiosos analisados é pouco divergente, dado que a FO faz mais uso de tal processo. No entanto, assim como observado na repetição como estratégia de progressão e produção textual, as porcentagens analisadas não revelam grandes distorções entre os dois jornais.

No que diz respeito às categorias "Especial" elaboradas a partir da referenciação, já foi citado aqui que dos 22 links disponibilizados pela FO, quatorze encontravam-se abrigados na categoria e oito destes foram elaborados a partir da repetição. Desta forma, seis links na categoria "Especial" da FO foram construídos com estratégias de referenciação. Já no jornal alemão, dos 28 links disponibilizados, apenas dois estão na categoria "Especial" e nenhum deles é elaborado a partir da referenciação. Assim, nota-se que o número de links analisados na categoria que orienta o interlocutor - de que há uma seção diferenciada e especial 
elaborada pelo jornal a fim de cobrir determinado acontecimento - é mais amplo na FO do que com relação ao FN. Isso mostra que o artifício lingüístico-textual usado pelos dois jornais é similar, dado que ambos sinalizam ao interlocutor de que há um espaço diferenciado. Por outro lado, o jornal alemão faz pouco uso desta estratégia, ao contrário da FO. Uma possível hipótese reside no fato de que o conceito de "Especial" é divergente para os dois jornais. Assim sendo, o jornal brasileiro pode considerá-lo como uma mera organização de links referentes ao acontecimento noticiado, ao passo que o alemão pode sugerir ao interlocutor o acesso a um dossiê, no qual reportagens diferenciadas em uma seção destacada são disponibilizadas ao interlocutor.

Fator preponderante para a existência da categoria "Especial" é o banco de dados ou memória (PALACIOS: 1999), o qual possibilita a existência de um hipertexto noticioso que pode ser linkado. A partir disso, notam-se outros aspectos detectados na análise. Em quatro dos 22 links dos hipertextos noticiosos da FO, observou-se a categoria "Leia tudo sobre [...]"., ou seja, 18,18\%. Já no FN, não foi observada tal categoria. Esta, além de sugerir um exemplo recente de formação da coerência textual, indica sobretudo que o jornal organiza cronologicamente um sem-número de hipertextos noticiosos relacionados a um aspecto do acontecimento noticiado.

Com relação ao aspecto midiático dos hipertextos noticiosos estudados, a FO não fez uso de links que possibilitam a integração entre diferentes linguagens. No entanto, o FN, dos seus 28 links, ofertou seis que continham vídeos a serem acessados pelos interlocutores, isto é, $21,4 \%$. Crê-se que a ferramenta utilizada pelo jornal alemão é um resposta às necessidades do público-leitor de cada veículo comunicativo. Além disso, ressalta-se que a porcentagem detectada é grande se comparada ao início do uso comercial da Internet ainda na década de 90. Assim, a possibilidade de o interlocutor escolher entre diferentes maneiras de se informar é explorada pelo FN somente a partir de links, ou seja, inicia-se a interação textualmente, passando ao espectro imagético por meio de indicações que ressignificam as palavras em vídeos. Trata-se também de um processo de construção de coerência não considerado por Koch $(2003,2004)$, já que é possível somente quando um texto noticioso é suportado eletronicamente e atravessado por links que são construídos de acordo com o aproveitamento da tecnologia telemática ofertada pela Internet. Desta forma, sugere-se um outro tipo de link, o qual denominado link hipermidiático, já que agrega na estrutura hipertextual uma linguagem diferente da textual. 
No âmbito do estudo da coerência sob o ponto de vista da lingüística-textual de linha cognitiva, notou-se que os links analisados mostram-se como fatores de coerência em hipertextos jornalísticos oriundos do jornal brasileiro FO e do alemão FN. A repetição e a referenciação, processos de construção textual observadas em textos impressos, foram aqui detectadas quando da produção de links. Por outro lado, os ineditismos considerados concernem ao suporte no qual os hipertextos noticiosos foram produzidos, como as categorias "Especial", "Leia mais" e os links aqui caracterizados e denominados links hipermidiáticos. Os primeiros casos ampliam a rede informativo-interpretativa do hipertexto noticioso a partir do isolamento de determinados referentes que, quando elencados para a produção de links, seccionam aspectos selecionados do fato noticiado, relacionando-o ao todo coerente do hipertexto, dando a ele sua característica hiper. Desta forma, o hipertexto noticioso é atravessado por outros hipertextos noticiosos a partir da ancoragem de referentes semanticamente relevantes para a interação textual, o que caracteriza uma espécie de coerência por meio da ativação de fatores cognitivos presentes em arquiteturas de conhecimento ressaltados na forma de links. Entende-se aqui que, no caso do hipertexto noticioso, tal característica é diferenciada, já que se pode interagir com diferentes acontecimentos noticiados que permeiam um ou diferentes aspectos do hipertexto noticioso. Assim, o link não é somente uma característica do hipertexto noticioso, um constante promovedor de ressignificação de sentidos.

Assim, no caso do T1, o mesmo não pode ser considerado um hipertexto noticioso e, desta forma, um texto. Ele abdica da coerência ao disponibilizar links que não performam uma continuidade de sentidos com o título. De acordo com Storrer (2002), a coerência é estrutural e textual. No hipertexto citado, há coerência estrutural, de modo que se percebe o nó e os links, fatores de existência do hipertexto. O aspecto técnico condiz com o arcabouço teórico utilizado na pesquisa. Por outro lado, a coerência textual, tida como um dos fatores de textualidade analisados por de Beaugrande \& Dressler (1981), não é atendida.

Essas considerações dirigem-se à discussão dos resultados em âmbito jornalístico. Apesar de fazer uso de estratégias de produção de texto observadas em Koch (2004), o que significa que os hipertextos noticiosos analisados são aqui considerados textos, já que suas estruturas, - leia-se nós e links, - promovem a continuidade de sentidos, essencial é anotar como estes links são construídos a partir da acessibilidade oferecida em ambiente telemático, 
como as categorias "Especial" e Leia Mais", bem como os links hipermidiáticos. Os links encontrados nesta pesquisa classificam-se em ressignificadores, apontadores e hipermidiáticos.

A referenciação e, subordinada a ela, a repetição, estratégias observadas também em textos impressos, convivem com tais processos de construção da coerência sustentadas em ambiente virtual, visualizando-se, portanto, links que dirigem o interlocutor cada vez mais ao seu sistema hipertextual. Trata-se dos links ressignificadores.

Além de operadores de evidência e exploração e de existência do hipertexto, os links são táticas jornalísticas, no sentido dado por Feres (2000), de apontar ao interlocutor de que estas facilidades oriundas da tecnologia hipertextual são aproveitadas pelo jornal, a fim de destacar seções e reportagens diferenciadas e coberturas feitas por uma equipe concentrada em um determinado acontecimento. Logo, os links apontadores ressignificam apenas um referente relacionado à temática do hipertexto noticioso com os elementos textuais "Leia Mais" e "Especial". Estas categorias dirigem o interlocutor a outro sítio presente no sistema hipertextual do mesmo jornal, ou com mais hipertextos noticiosos, ou, ainda, com reportagens diferenciadas.

Já os links hipermidiáticos dizem respeito àqueles que ressignificam referentes a partir de outras linguagens presentes na Internet, como imagens e vídeos. Esta mistura propicia um hipertexto plurissemiótico, preconizando a integração não somente de veículos comunicativos em um suporte único, mas também de interlocutores que optam por uma linguagem ou outra. A forma de construção destes links dá-se a partir da repetição de sentidos presentes na proposição global do hipertexto noticioso, e sempre com a categoria "Vídeo".

Pelo exposto, destacamos os resultados mais sugestivos da pesquisa:

- O questionamento do conceito de "hipertexto", a partir da averiguação de que um hipertexto noticioso oriundo da FO não apresentou links coerentes com a proposição global;

- A ampliação do conceito de link ao seu aspecto textual-discursivo, já que aponta, a partir da referenciação a objetos do discurso, quais referentes destacam-se em 
um hipertexto noticioso, promovendo a ressignificação destes através de outros hipertextos;

- A discussão acerca da acessibilidade dos links, visto que, apesar de poderem ou não ser acessados pelos interlocutores, tais ferramentas são estrategicamente elaboradas a fim de que o interlocutor não se ausente de um sistema hipertextual, dado que a continuidade de sentidos o impede de seccionar e interromper o trabalho de interação com o texto;

- A ampla utilização da repetição por parte da FO como estratégia de progressão textual concretizada nos links apontadores, visto que sempre apontavam para um portal denominado "Leia Mais" ou "Especial”;

- A referenciação a elementos textuais-discursivos por meio de diferentes estratégias que não a repetição foi largamente usada pelo FN;

- A existência em grande número de links hipermidiáticos no FN, ao passo que nenhum foi observado na FO;

- A utilização em larga escala das categorias "Leia Mais" e "Especial" pelo jornal brasileiro FO, o que sugere uma tática jornalística de, em primeira instância, organizar de um mundo relevante e, adiante, de um mundo visto somente através de uma linha editorial que procura se mostrar suficiente ao interlocutor, mostrando o link não somente como operador textual-discursivo, mas também jornalístico. 


\section{Considerações finais}

A linguagem tem uma relação peculiar com os meios virtuais de tecnologia, tornando-se ainda mais plástica e maleável (MARCUSCHI \& XAVIER: 2005), assim como a prático jornalística empreende um trabalho estratégico desde a seleção de palavras até a elaboração de excertos que se destacarão nas notícias. O texto, portanto, não é um amontoado de frases, mas um todo complexo de natureza semântico-cognitiva, pelo qual o conhecimento é veiculado.

Entretanto, este conhecimento nem sempre visa o discernimento acerca dos fatos cotidianos que influenciam nossos modos de viver. A informação atualmente é refém de grandes jornais que, travestidas dos mitos da informatividade e da objetividade (MOSCA: 1995), levam ao público-leitor um mundo desnecessário de exploração, mas já livre de divergências a partir das editorias frenéticas e dos códigos de redação que impõem aquilo que deve ser escrito. Por outro lado, a impossibilidade de se vivenciar as situações reais preconizam a importância gradativa dos meios de comunicação, justificando-se o imediatismo das notícias, criando um aspecto duvidoso no que diz respeito à questão: o que é realidade?

Subjaz a este jogo de detenção informativa e pluralidade de suportes comunicativos uma possível revolução tecnológica. A possibilidade de se observar o que se passou além do que é visto nos grandes jornais, ou seja, de se extrair de um acontecimento algo que não está de acordo com interesses de uma corporação, aumenta as possibilidades de intermediação entre os interlocutores no que diz respeito não ao contato direto com os fatos, mas sim, no que concerne às intermediações e aos critérios estabelecidos para a mesma. Isso proporciona ao interlocutor uma experiência diferenciada no que diz respeito à textualização do que se passa no mundo. Desta feita, o texto torna-se não somente um objeto de conhecimento, mas também um produto desencadeador de batalhas de conhecimento.

O texto, se observado a partir de seu aspecto lingüístico-pragmático, torna-se hiper em ambiente virtual quando da gravitação de links, dispositivos de atualização instantânea. Estas ferramentas implicam acesso a outros sítios, conferindo a elas um aspecto imediatista e, simultaneamente, de orientação textual-argumentativa. Estes links, até a década de 50, eram ferramentas que visavam o acúmulo de informação. Com o desenvolvimento do hipertexto, os 
links tornaram-se não somente operadores de ligação entre diferentes hipertextos. Como demonstrou a presente pesquisa, os links nos hipertextos jornalísticos performam uma continuidade de sentidos entre o linear, ou seja, o nó, e seus dispositivos de atualização instantânea. Desta maneira, o hipertexto, formado a partir de nós e links, é visto não mais somente a partir de um viés técnico, mas também textual.

Nesta análise, observou-se qual estratégia empreendida no uso de links pelo jornal brasileiro FO e pelo alemão Frankfurter Allgemeine Zeitung. NET. As maneiras de construção dos links baseiam-se numa estratégia de construção de sentidos denominada referenciação, destacando-se dela a repetição. As observações feitas por Koch (2004) procuram, como tecido no aparato teórico desta pesquisa, dar conta destes conceitos. Diferentes formas de se referir a um referente enquadram-se na referenciação, enquanto que a repetição, como uma das estratégias sob o conceito de referenciação, é a reutilização de referentes já presentes no universo textual. Apesar disso, tal estratégia não diz respeito a uma simples repetição de referentes, visto que os objetos de discurso encontram-se em blocos textuais que se diferenciam de acordo com a progressão textual, em parte abarcada pela progressão tópica.

Depreende-se destas incursões oriundas de estudos de textos lineares que os links divergem substancialmente destas considerações em razão destas cápsulas semântico-textuais (KOCH: 2004) que influenciam a interação com o nó hipertextual. Eles destacam referentes ali presentes, "iluminando-os".

O estudo dos links no hipertexto noticioso sugere formas inéditas de continuidade de sentidos se confluídas com os aspectos técnicos do hipertexto noticioso. Tratam-se dos links ressignificadores, apontadores e hipermidiáticos. Além disso, os links mostram-se como ferramentas estratégicas de cunho jornalístico que, a partir de construções semântico-textuais, apontam aos interlocutores as possibilidades de exploração no sítio eletrônico do jornal. Desta forma, a pesquisa procurou não só observar se os links são operadores de continuidade de sentidos em hipertextos noticiosos, como também discutir de que maneira estes links foram construídos. Notou-se, portanto, que o hipertexto noticioso faz uso da linguagem textual suportada em um ambiente telemático, o que gera diferenciações com relação à construção semântico-textual dos links. Estas diferenciações baseiam-se em ordens estruturais, semântico-textuais, hipertextuais e jornalísticas. As estruturais dão-se em razão da gravitação 
de links ao redor de um hipertexto jornalístico, o que pode alterar fundamentalmente o processo de interação com o mesmo; consequentemente, isso implica em divergências de natureza semântico-textuais em razão do destaque de determinados referentes no universo textual; mais adiante, questiona-se o conceito de hipertexto: se é um texto, onde deve estar a coerência?; por fim, as divergências de caráter jornalístico, baseadas no papel do webjornalismo na sociedade contemporânea.

Algumas questões ainda necessitam de discussões mais específicas.

Primeiramente, as considerações acerca do hipertexto. A presente pesquisa demonstrou que o link é fator de subsistência do hipertexto. No entanto, não somente seu aspecto técnico é essencial, mas também a continuidade de sentidos que o mesmo promove. Assim, a análise de um dos hipertextos noticiosos estudados mostrou que se trata tecnicamente de um hipertexto, mas não o é, já que seus links não são coerentes com a proposição global.

A pesquisa observou como fatores de coerência de acordo com as estratégias de referenciação e repetição. Assim com em Castro (2001), que empreendeu uma classificação dos links a partir de elementos da retórica, a lingüística do texto deveria partir para o estudo da coesão e da coerência nos hipertextos, a fim de analisar se as definições de ambos os conceitos manteriam-se, se as estruturas hipertextuais fazem de um hipertexto um texto e as maneiras pelas quais isso ocorre.

Outra questão diz respeito à construção dos links a partir das categorias "Leia Mais", "Especial" e "Vídeo". Apesar de ressignificarem referentes presentes nos títulos dos hipertextos noticiosos, tais categorias empreendem aspectos técnicos e textuais que, conjuntamente, sugerem uma nova forma de coerência. Como já colocado, urge a necessidade de estudos que levem em conta estes fatores, sobretudo se operados em hipertextos noticiosos que, atualmente, desempenham um papel fundamental na rede virtual de comunicação.

Além das problemáticas elencadas, mais uma reside na construção do link e no seu comportamento diante da proposição global do hipertexto noticioso. De acordo com os apontamentos de Comassetto (2001) com relação à construção do título em notícias impressa, observando-se a classificação proposta pelo autor e comparando-a com os resultados obtidos nesta pesquisa, nota-se que os mecanismos de construção de ambas as categorias são 
semelhantes. No entanto, os links, além de se comportarem de acordo com aspectos textuais, também levam em conta as possibilidades técnicas oferecidas pela tecnologia hipertextual e, por isso, diferenciam-se dos outros elementos presentes no hipertexto. Assim, falando-se em gêneros discursivos presentes nos jornais, é fundamental a ampliação de estudos neste âmbito por se tratar da comunicação de fatos relevantes para uma determinada sociedade.

Frente a estes questionamentos, surge a indagação relacionada à coerência de design colocada por Storrer (2002). A disposição dos links nos hipertextos jornalísticos analisados também sugere pesquisas mais específicas. Viu-se que no jornal brasileiro FO, os links encontram-se abaixo do nó. Já no alemão $F N$, as ferramentas de acesso instantâneo fícam no lado superior direito do nó. Viu-se pela análise da coerência que os links dos dois jornais diferenciam-se em suas elaborações, mas não se observou a razão de se localizarem em espaços divergentes na página eletrônica.

Assim, coloca-se em questionamento o papel do webjornalismo na construção dos links. Por quê os links performam uma continuidade de sentidos? Qual a razão de o jornal brasileiro ter formulado links que, em grande parte, deram-se a partir da repetição? E o por quê o contrário foi observado no jornal alemão? Qual o motivo do grande número de links apontadores na FO? Na presente pesquisa, esses dados foram observados a partir de um viés lingüístico, além de algumas considerações no âmbito jornalístico.

O hipertexto noticioso, como produto de um trabalho jornalístico que visa a interpretação de um fato ou acontecimento, pode ser estendido e se tornar produto de interação a partir das facilidades oferecidas pela tecnologia hipertextual. Se o papel do jornal impresso é recortar o mundo e levar o que é importante ao interlocutor, o webjornalismo transgride os fatos que permeiam este mundo e os desenvolvem a partir de referentes que centralizam a orientação semântico-textual da produção noticiosa. Esta tecnologia, combinada ao valor da informação na sociedade contemporânea, acaba por sugerir a criação de links hipermidiáticos, que aliam textos a vídeos, e links orientadores, que organizam uma série de hipertextos noticiosos relacionados a um aspecto do fato. Tal possibilidade eleva o link de seu aspecto técnico a sua importância textual, partindo de um simples conector de hipertextos a um gravitador semântico-textual que expande permanentemente as fronteiras cognitivas colocadas, em primeira instância, na proposição global de um hipertexto noticioso. Esta expansão diz respeito não somente à ampliação do fator informatividade, mas também à 
extensão de um mesmo mundo recortado e interpretado, dado que não se observou links externos. Estes representariam a interlocução com outra linha editorial, o que sugere outro construto textual contraditório a outro hipertexto noticioso veiculado por outro jornal.

Por fim, não somente as considerações provocadas pela pesquisa, mas também as questões aqui colocadas e por meio dele não resolvidas, sugerem que o link tem papel fundamental não somente em sua função hipertextual, mas também na evolução da lingüística do texto. $\mathrm{O}$ estudo de recentes gêneros discursivos a partir de suas teorias sugere o questionamento de alguns conceitos, o que pode levar à discussão da própria coerência. Neste universo digital, no qual um mundo paralelo vem se desenvolvendo, tais similaridades passam a ser destoantes, assim como vem ocorrendo com os grandes jornais. A explosão de textos oriundos desta insólita plataforma que é a Internet propicia a ampliação do olhar do lingüista para a ocorrência de um outro tipo de interação textual. Essencial disto tudo é que estas mudanças dão-se pelas veias textuais-discursivas, isto é, pelo objeto de conhecimento denominado texto. 


\section{Bibliografia}

ANTOS, G. Os textos como formas constitutivas do saber. Sobre algumas hipóteses para a fundamentação da lingüística de texto à base de uma teoria evolucionária. In: ANTOS, G. \& TIETZ, H. O futuro da lingüistica de texto. Tradições, transformações, tendências. Tübingen: Niemeyer, 1997.

ARAÚJO, U. I. Tessitura textual: coesão e coerência como fatores de textualidade. São Paulo: Humanitas, 2000.

BAKHTIN, M. Estética da criação verbal. Tradução de Paulo Bezerra São Paulo: Martins Fontes, 2000. Título original: Estetika slovesnogo tvorchestva.

BARBOSA, S. A informação de proximidade no jornalismo online. 2001. Disponível em: www.facom.ufba.br/jol/producao.htm.2001. Acesso em: 10/03/2006.

BARDOEL, J. \& DEUZE, M. Network journalism. Disponível em: users.fmg.uva.nl/mdeuze/pub19.htm. Acesso em 20/11/2005.

BASTOS, L. K. Coesão e coerência em narrativas escolares. $1^{\mathrm{a}}$ edição. São Paulo: Martins Fontes, 1985.

de BEAUGRANDE, R. New Foundations of the Science of Text and Discourse: Cognition, Communication, and the Freedom of Access to Knowledge and Society. Norwood/ New Jersey: Ablex Publishing Corporation, 1997.

BOLTER, J. D. Writing space: the computer, hypertext and the history of writing. Hillsdale (Nova Jersey): Lawrence Erlbaum Associates, 1991.

BRAIT, B. Texto jornalístico: modos de leitura. Anais do XXXIX Seminários do GEL, Franca: Unifran, v. 39, n. 1, pp.: 85-92, 1990. 
BURBULES, N. C. Rhetorics of the web: hyperreading and critical literacy. In: SNYDER, H. Hypertext: the electronic labyrinth. Washington: New York Academic Press, 1998.

BUSH, V. As we may think. Disponível em: www.theatlantic.com/unbound/flashbks/computer/bush.htm. Acesso em: 21/08/2005.

CASTRO, Sandra Carla Ferreira de. A retórica dos links no hipertexto. Pernambuco, 2001. 178 f. Dissertação (Mestrado em Letras) - Centro de Artes e Comunicação, Universidade Federal de Pernambuco.

CHAPARRO, M. C. Funeral da notícia impressa. s/d. Disponível em: http://www.midiamix.com.br/assessoria/nota3.htm. Acesso em: 15/11/2004.

CHARTIER, R. O mundo como representação. Estudos Avançados, v. 11, n. 5, pp.: 173-191, 1991.

COMASSETTO, L. R. As razões do título e do lead: uma abordagem cognitiva da estrutura da notícia. Florianópolis, 2001. 96 f. Dissertação (Mestrado em Lingüística) Centro de Comunicação e Expressão, Universidade Federal de Santa Catarina.

CONKLIN, J. Hypertext: An introduction and survey. Computer Magazin, v. 20, n.1, 1987.

DIAS, C. A. Hipertexto: evolução histórica e efeitos sociais. Ci. Inf. Ministério da Ciência e Tecnologia/ CNPq, Brasília, v. 28, n. 3, pp.: 269-277, 1999.

van DIJK, T. A. Cognição, discurso e interação. $4^{\mathrm{a}}$ edição (português). São Paulo: Contexto, 2002.

. New(s) Racism. A discourse analytical approach. In: COTTLE. C. (ed.), Ethnic Minorities and the Media. Milton Keynes, Inglaterra: Open University Press, 2000 . 
- Power and the news media. In: PALETZ, D. (ed.). Political, Communication and Action. Cresskill, Nova Jérsei: Hampton Press, 1995.

The interdisciplinary study of news as discourse. In: BRUHN-JENSEN, K. \& JANKOWKSI, N. (eds.), Handbook of Qualitative Methods in Mass Communication Research. London: Routledge, 1991.

. Race, riots and the press. An analysis of editorials in the British press about the 1985 disorders. Gazette, v. 43, n. 1, pp.: 229-253, 1989.

. Semantics of a press panic: The Tamil "invasion". European Journal of Communication, v. 3, n. 1, pp.: 167-187, 1987.

. Structures of news in the press. In: van Dijk, (ed.) Discourse and Communication. Berlim/ Nova York: De Gruyter, 1985.

DITTRICH, I. J. Descrições Definidas: Referência, informação e argumentação na reportagem sobre economia em magazines de informação geral. Florianópolis, 2001. 192 f. + anexos. Tese (Doutorado em Lingüística) - Centro de Comunicação e Expressão, Universidade Federal de Santa Catarina.

DOUGLAS, J. Y. Will the most reflexive relativist please stand up: hypertext, argument and relativism. In: SNYDER, I. (ed.). Page to Screen: Taking literacy into the electronic era. London, Routledge, 1998.

FERES, Lílian Márcia Chein. Webjornalismo: a nova geração da informação eletrônica. São Paulo, 2001. 197 f. Dissertação (Mestrado em Ciência da Informação/ Jornalismo) - Escola de Comunicação e Artes, Universidade de São Paulo. 
FIDALGO, A. Sintaxe e semântica das notícias online. Para um jornalismo assente em base de dados. 2003. Disponível em: www.bocc.pt/fidalgo. Acesso em: 20/04/2006.

FREIRE, G. H. Construindo um hipertexto com o usuário. Ci. Inf.. Ministério da Ciência e Tecnologia/ CNPq, Brasília, v. 29, n. 3, pp.: 101-110, 2000.

GONÇALVES, E. M. La estructura de la noticia en las redes digitales - Un estudio de las consecuencias de las metamorfosis tecnológicas en el periodismo. Barcelona, 2000. 369 f. + anexos. Tese (Doutorado em Comunicação) - Faculdade de Ciências da Comunicação, Universidade Autónoma de Barcelona. Disponível em: www.facom.ufba.br/producao_teses.htm. Acesso em: 01/04/2006.

GOUAZÉ, J. Os dispositivos da comunicação. Palestra proferida na FACOM/ UFBA, Salvador, Brasil, em 25.10.1999.

GUIMARÃES, Elisa. A articulação do texto. $1^{\mathrm{a}}$ edição (português). São Paulo: Ática, 1990.

HEIM, M. The Metaphysics of Virtual Reality. New York: Oxford University Press, 1993.

JOHNSON-EILOLA, J. Reading and writing in hypertext: vertigo and euphoria. In: SELFE, C. L. \& HILLIGOSS, S. (eds.) Literacy and computers: the complications of teaching and learning with technology. New York: The Modern Language Association of America, 1994.

KILFEATHER, E. Hypertext, Narrative and Coherence: The role of the reader and writer in the practice of hypertext. Dublin, 1998. $133 \mathrm{f}$. + anexos. Tese (Doutorado em Estudos da Mídia) - Dublin Institut of Technology.

KOCH, I. G. V. Coerência e manutenção temática no hipertexto. s/d. Disponível em: http://www.unlu.edu.ar/ portugues/artigosconsulta.htm. Acesso em: 25/04/2006. 
. Introdução à lingüística textual. $1^{\mathrm{a}}$ edição (português). São Paulo:

Martins Fontes, 2004.

. O texto e a construção dos sentidos. $7^{\mathrm{a}}$ edição (português). São Paulo:

Contexto, 2003.

. Como se constrói a coerência. Anais do XXXIV Seminários do GEL, Taubaté: UNITAU, v. 34, n.1, pp.: 157-161, 1988.

LAGE, N. Ideologia e técnica da notícia. $3^{\mathrm{a}}$ edição (português). Florianópolis: Insular, 2001.

LANDOW, G. P. Hyper/ Text/ Theory. Baltimore/ London: The John Hopkins University Press, 1994.

LEVY, P. Cibercultura. Tradução de Carlos Irineu da Costa. São Paulo: Editora 34, 1999. Título original: Cyberculture.

- As tecnologias da inteligência: o futuro do pensamento na era da informática. Tradução de Carlos Irineu da Costa. Rio de Janeiro: Editora 34, 1993. Título original: Les technologies de l'intelligence.

MARCUSCHI, L. A. Hipertexto: definições e visões. Apresentado no I Encontro sobre hipertexto. Pernambuco, 2000.

- Linearização, cognição e referência: o desafio do hipertexto. Línguas e instrumentos lingüísticos, Campinas: Instituto de Estudos da Linguagem, v. 3, n. 1, pp: 21-46, 1999. 
- A repetição na língua falada como estratégia de formulação textual. In: KOCH, I. G. V. (org.). Gramática do Português falado. Volume VI. $2^{\text {a }}$ edição (português). Campinas: Edunicamp/ FAPESP, 1997.

- Lingüística de texto: o que é como se faz. Série Debates 1. Recife: Universidade Federal de Pernambuco, 1983.

MARCUSCHI, L. A. \& XAVIER, A. C. (orgs.). Hipertexto e gêneros digitais: novas formas de construção de sentido. $1^{\mathrm{a}}$ edição (português). Rio de Janeiro: Lucerna, 2005.

MEDINA, C. \& GRECO, M. (orgs.) Saber plural: novo pacto para a ciência 3. São Paulo: ECA/ USP/ CNPq, 1994.

MIELNICZUK, L. Considerações sobre interatividade no contexto das novas mídias. 2001a. Disponível em: www.facom.ufba.br/jol/producao2001.htm. Acesso em: 12/03/2006.

- Características e implicações do jornalismo na Web. $2001 \mathrm{~b}$. Disponível em: www.facom.ufba.br/jol/producao2001.htm. Acesso em: 12/03/2006.

. Interatividade como dispositivo do jornalismo online. Disponível em: www.facom.ufba.br/jol/producao2000.htm. 2000. Acesso em: 12/03/2006.

. Interatividade no jornalismo online: o caso do NetEstado. 1999. Disponível em: www.facom.ufba.br/jol/producao1999.htm. Acesso em: 12/03/2006.

MIELNICZUK, L. \& PALACIOS, M. Considerações para um estudo sobre o formato da notícia na Web: o link como elemento paratextual. 2001. Disponível em: www.facom.ufba.br/jol/producao2001.htm. Acesso em 14/08/2005.

MINGORANCE, S. A. Influências do hipertexto na geração de jornalismo interpretativo na Internet - um estudo de caso comparativo dos jornais impresso e online $O$ 
Estado de S. Paulo. São Paulo, 2002. 183 f. + anexos. Dissertação (Mestrado em Jornalismo) - Escola de Comunicação e Artes, Universidade de São Paulo.

MONDADA, L. \& DUBOIS, D. Construction des objets de discours et categorization: une approche des processus de referenciation. In: BERRENDONNER, A. \& REICHLERBEGUELIN, M-J. (eds.) Du sintagme nominal aux objets-de-discours. Neuchâtel: Université de Neuchâtel, 1995.

MONTEIRO, S. D. A forma eletrônica do hipertexto. Ci. Inf. Ministério da Ciência e Tecnologia/ CNPq, Brasília, v. 29, n. 1, pp.: 25-39, 2000.

MOREIRA, W. Produção e leitura de hiperdocumentos: novos modos de interação leitor-texto. Revista Informação e sociedade, João Pessoa: Centro de Ciências Sociais Aplicadas, $\quad$ n. $\quad 1, \quad$ v. 13, pp: 1-9, 2003. Disponível em: www.informacaoesociedade.ufpb.br/IS1310301.htm. Acesso em: 19/12/2005.

NELSON, T. H. Literaty machines 93.1. Sausalito (Califórnia): Mindful Press, 1993. . The Hypertext, in: Proc. World Documentation Federation Confederation, 1965.

NIELSEN, J. Multimedia and Hypertext: the Internet and beyond. Boston: AP Professional, 1995.

OLIVER, H. Hyper-Text-Linguistik- TAH: Ein textlinguistisches Analysemodell für Hypertexte. Theoretisch und praktisch exemplifiziert am Problemfeld der typisierten Links von Hypertexten im World Wide Web. Munique, 2003. 229 f. + anexos. Tese (Doutorado em Filosofia) - Fakultät für Philosophie, Wissenschaftstheorie und Religionswissenschaft, Ludwig-Maximilians Universität.

PADILHA, S. C. O local na era do global: o aproveitamento da Internet como instrumento e fonte de conhecimento para a produção jornalística dos profissionais dos jornais A Folha de Boa Vista e BrasilNorte. São Paulo, 2003. 182 f. + anexos. Dissertação 
(Mestrado em Ciências da Comunicação) - Escola de Comunicação e Artes, Universidade de São Paulo.

PALACIOS, M. Ruptura, continuidade e potencialização no jornalismo online: o lugar da memória. In: MACHADO, E. \& PALACIOS, M. (eds.) Modelos de jornalismo digital. Salvador: Calandra, 2003a (pp.: 1-17).

. Fazendo jornalismo em redes hibridas: notas para discussão da Internet enquanto suporte mediático. 2003b. Disponível em: www.facpucminas.br/jornalismocultural/m_palacios.doc. Acesso em: 15/03/2006.

Jornalismo online, informação e memória: apontamentos para debate. 2002. Disponível em: www.facom.ufba.br/jol/producao2002.htm. 2002. Acesso em $02 / 05 / 2005$.

- Hipertexto, fechamento e o uso do conceito de não-linearidade discursiva. Lugar comum- Estudos de mídia, cultura e democracia. Rio de Janeiro, UFRJ/ Escola de Comunicação/ Núcleo de Estudos e Projetos em Comunicação, v. 8, n. 1. pp.: 111$121,1999$.

PALACIOS, M., MIELNICZUK, L., BARBOSA, S., RIBAS, B. \& NARITA, S. Um mapeamento de características e tendências no jornalismo online brasileiro. 2002. Disponível em: www.facom.ufba.br/jol/producao2002.htm. Acesso em 14/08/2005.

PRIMO, A. \& RECUERO, R. Participatory creation of multidirecional links aided by the use of Co-link technology, 2004a. Disponível em: www6.ufrgs.br/colink/publications/primorecuero.pdf. Acesso em 15/02/2006.

. Co-links: proposta de uma nova tecnologia para a escrita de links multidirecionais, 2004b. Disponível em: www6.ufrgs.br/colink/publications/2004_ap.pdf. Acesso em 15/02/2006. 
PRIMO, A., RECUERO, R. \& ARAÚJO, R. M. The Co-link Project: collaborative writing of multidirectional links. Disponível em: www6.ufrgs.br/colink/publications/Primo.pdf. Acesso em 15/02/2006.

RIBAS, B. Infografia multimídia: um modelo narrativo para webjornalismo. 2004. Disponível em: www.facom.ufba.br/jol/producao2004.htm. Acesso em 04/05/2005.

RODRIGUES, A. F. Como elaborar citações e notas de rodapé. $1^{\mathrm{a}}$ edição. (português). São Paulo: Humanitas/ FFLCH/ USP, 2004.

. Como elaborar referência bibliográfica. $3^{a}$ edição. (português). São Paulo: Humanitas/ FFLCH/ USP, 2004.

SALMERÓN, L., CAÑAS, J. J., KINTSCH, W. \& FAJARDO, I. Reading strategies and hypertext comprehension. Discourse Processes, v. 40, n.3, pp.: 171-191, 2005.

SANTO, C. do E. \& FREIRE, G. H. “Quissamã somos nós!”: construção participativa de hipertexto. Ci. Inf. Ministério da Ciência e Tecnologia/ CNPq, Brasília, v. 33, n. 1, pp.: 155-168, 2004.

SCHNOTZ, W. Aufbau von Wissenstrukturen. Untersuchungen zur Kohärenzbildung bei Wissenserwerb mit Texten. Weinheim: Beltz, 1994.

SMITH, C. F. Hipertextual thinking. In: SELFE, C. L. \& HILliGOSS, S. (eds.) Literacy and computers: the complications of teaching and learning with technology. New York: The Modern Language Association of America, 1994.

SNYDER, I. Hypertext: the eletronic labyrinth. Washington: New York, 1998.

SPERBER, D. \& WILSON, D. Relevance, communication and cognition. $2^{\mathrm{a}}$ edição (inglês). Oxford: Blackwell, 1995. 
STORRER, A. Coherence in text and hypertext. In: Document Design, John Benjamins Publishing Company, v. 3, n. 2, pp.: 156-168, 2002.

URBANO, H. Marcadores Conversacionais. In: PRETI, D. (org.). Análise de textos orais. $3^{a}$ edição (português). São Paulo: Humanitas, 1997.

VANTI, N. Os links e os estudos webométricos. Ci. Inf. Ministério da Ciência e Tecnologia/ CNPq, Brasília, v. 34, n. 1, pp.: 78-88, 2005.

VITTADINI, N. Comunicar com los Nuevos Media. In: BETTETINI, G., COLOMBO, F. et alii. Las nuevas tecnologias de lá comunicácion. Barcelona: Piadós, 1995.

XAVIER, A. C. A necessidade de pesquisa aplicada no jornalismo digital. 2002. Disponível em: www.facom.ufba.br/jol/producao2002.htm. Acesso em: 20/03/2006.

. Processos de referenciação no hipertexto eletrônico. Cadernos de estudos lingüísticos. Campinas: IEL/ UNICAMP, v. 41, n. 1, pp: 165-176, 2002. . Hipertexto: novo paradigma textual? Investigações: Lingüística $e$ Teoria Literária, Recife: Universidade Federal de Pernambuco, v. 12, n. 1, pp: 177-192, 2000.

ZAMORA, L. N. Los periódicos online, sus características, sus periodistas y sus lectores. Sala de Prensa, Madri: Universidade Complutense de Madri, v. 34, n.2, 2001. 
Anexos 
16/01/2006 - 10 h05

Bachelet vence e será $\mathbf{1}^{\mathrm{a}}$ mulher a governar o Chile

MARCIA CARMO

da BBC Brasil, em Santiago

A candidata governista Michelle Bachelet venceu as eleições presidenciais neste domingo no Chile. Ela será a primeira mulher a ocupar o Palácio presidencial de La Moneda.

$\mathrm{O}$ anúncio foi feito pelo senador Andres Zaldívar, segundos depois de o Ministério do Interior divulgar os primeiros resultados oficiais do segundo turno das eleições presidenciais.

Cerca de três horas após o fechamento das urnas, o Ministério do Interior divulgou que com $97,52 \%$ das urnas apuradas, Bachelet, de 54 anos, recebeu 53,51\% dos votos válidos e Piñera, $46,48 \%$.

Pouco antes, o candidato da oposição, Sebastián Piñera, reconheceu a derrota para Bachelet. "Felicito a candidata", disse, ao lado da mulher e dos filhos. "Mas quero lembrar que a

Alianza está mais viva e unida que nunca e vamos continuar trabalhando para que o país tenha menos desemprego e mais igualdade social", afirmou ele.

Para o ex-ministro da Educação do governo Lagos, Sergio Bittar, "Bachelet é a primeira presidenta da América do Sul e vai fazer o melhor para o Chile".

Segundo ele, Bachelet representa uma mudança cultural neste país sempre apontado como conservador e machista, como recordaram diferentes políticos da Concertación, a frente governista - concentrados na noite deste domingo no hotel San Francisco, centro de Santiago, onde funciona o centro de campanha da futura presidente do país.

\section{Transição}

O presidente Ricardo Lagos deve transferir o poder a Bachelet no dia 11 de março. Ela assumirá para um mandato de quatro anos, ao final dos quais a Concertácion (centroesquerda) terá completado 20 anos consecutivos no governo.

A transição presidencial já teve início. Lagos convidou Bachelet para um café da manhã, onde pretende "contar a ela" tudo o que pode, aquilo que aprendeu em seis anos de governo.

A conversa entre os dois foi mostrada, ao vivo, por diferentes emissorras de televisão do país. "Então, prefiro que voce vá à minha casa", disse ela. "Combinado, amanhã (segunda-feira) às $9 \mathrm{~h}$ ", respondeu ele. O diálogo provocou aplausos no comitê de Bachelet.

Os dois são socialistas e, na opinião de diferentes integrantes da Concertación, como os senadores Alejandro Foxley e Andres Zaldívar, Lagos terminou o "período de transição democrática" do Chile, após a era do ditador Augusto Pinochet, e Bachelet iniciará uma "nova etapa do país".

Para Zaldívar, o fato de uma mulher chegar pela primeira vez à presidência ajudará nessa nova etapa. "A mulher é mais sensível e por isso Bachelet será capaz de entender os problemas sociais de nosso povo e implementar as medidas necessárias para um país mais igual", disse.

Para Foxley, com um Congresso que terá maioria da Concertación será "mais fácil" implementar as reformas sociais necessárias.

Segundo ele, cotado para assumir o Ministério das Relações Exteriores, Bachelet começará imediatamente a formar sua equipe de governo, já que seu programa com 36 medidas foi divulgado durante a campanha presidencial.

O deputado e senador eleito Juan Pablo Letelier, do Partido Socialista, filho do ex-chanceler Orlando Letelier, morto num atentado em Washington de autoria da Dina (polícia do governo Pinochet), disse que o país hoje está "maduro" para realizar as mudanças que não foram possíveis há trinta anos 
Ele se referia ao ex-presidente socialista Salvador Allende, morto em 1973, durante o golpe liderado por Pinochet. "Bachelet representa uma etapa histórica do Chile", disse.

\section{DESTAQUES}

Arábia Saudita: Tumulto mata 50 em peregrinação a Meca

Saúde: Novas tecnologias aumentam estresse, diz ONG

Fama: Angelina Jolie está grávida de Brad Pitt, diz assessora

On-line: Diário musical de Mozart vai para a internet 


\section{Wahlen}

\section{Sozialistin Bachelet erste Präsidentin Chiles}

16. Januar 2006 Die Sozialistin Michelle Bachelet wird die erste Staats- und Regierungschefin des südamerikanischen Wirtschafts-Musterlandes Chiles. Bei der zweiten Runde der Präsidentenwahlen am Sonntag erhielt die 54jährige frühere Kinderärztin nach Auszählung fast aller Stimmzettel rund 53,5 Prozent. Ihr konservativer Rivale Sebastián Piñera, einer der reichsten Unternehmer Chiles, kam nach Behördenangaben auf rund 46,5 Prozent. Die Nachfolgerin von Ricardo Lagos ist auch die erste gewählte Präsidentin in Südamerika.

In ihrer ersten Rede nach dem Wahlsieg sagte Bachelet, sie wolle mit „neuen Gesichtern” und mit ebenso vielen Frauen wie Männern im Kabinett regieren. Der Wahlausgang sei „ein Sieg Chiles". Sichtlich gerührt sagte sie vor Tausenden jubelnder Menschen vor einem Hotel in Santiago, Chile werde „wieder einmal die Welt beeindrucken”. Es könne reicher werden, „ohne die Seele zu verlieren, ohne die Luft, die wir atmen, oder das Wasser, das wir trinken, zu verschmutzen".

\section{Vor Pinochet in die DDR geflüchtet}

Bachelets Mitte-Links-Bündnis „Übereinkunft für die Demokratie” regiert im Andenland seit Ende der Diktatur von General Augusto Pinochet. Die spätere Gesundheits- und Verteidigungs-Ministerin lebte während der Pinochet-Diktatur (1973-1990) in der DDR.

Das chilenische Fernsehen übertrug am Abend (Ortszeit) live ein Telefongespräch zwischen Bachelet und dem scheidenden Präsidenten Lagos. „Das ist ein Sieg aller Chilenen”, sagte dabei die künftige Präsidentin, die den friedlichen Verlauf des Urnengangs würdigte. Lagos sprach von einem ,großen Tag für Chile”. „Mit Dir wird Chile eine große Regierung und eine große Frau haben", sagte Lagos. Bachelet wird ihre vierjährige Amtszeit am 11. März antreten.

Der konservative Oppositionskandidat Piñera, Medienmogul und mit einem geschätzten Vermögen von einer Milliarde einer der reichsten Männer Chiles, räumte seine Niederlage ein. „Ich beglückwünsche Frau Bachelet zum Wahlsieg”, sagte der 56jährige Piñera vor Parteifreunden und Anhängern. Er wünschte Bachelet alles Gute.

\section{Für eine gerechtere Einkommensverteilung}

Anhänger von Bachelets Mitte-Links-Bündnis waren schon nach ersten Teilergebnissen mit Sekt auf die Straßen gegangen, um den Sieg zu feiern. Nach Polizeischätzung versammelten sich allein auf der Hauptstraße Paseo Alameda in Santiago eine halbe Million Menschen.

Bachelet strebt in Chile eine gerechtere Einkommensverteilung an. In ihrer Mitte-LinksKoalition, die seit 15 Jahren regiert, gilt sie als „Linksaußen”. Im ersten Wahlgang Mitte Dezember hatte sie mit 46 Prozent etwa 20 Prozentpunkte vor Piñera gelegen, die erforderliche absolute Mehrheit aber verfehlt.

Der Urnengang verlief in den knapp 33.000 Wahllokalen ohne nennenswerte Zwischenfälle. Rund 8,2 Millionen Stimmberechtigte waren zu den Urnen gerufen. Die beiden Kandidaten hatten bereits am frühen Morgen ihre Stimme abgegeben. 20.000 Soldaten und Polizisten waren im Einsatz. 
Zum Thema:

Michelle Bachelet: Gefeiert wie eine Heilige

Video: Bachelet gewinnt Präsidentenwahl in Chile

Chilenische Präsidentschaftswahlen: Stichwahl entscheidet 
16/01/2006 - 13h14

\section{Ataque suicida no Afeganistão deixa 20 mortos}

da Efe, em Cabul

Ao menos 20 pessoas morreram nesta segunda-feira em um ataque suicida ocorrido na em Spinboldak, perto da fronteira com o Paquistão, informou o governador da Província de Candahar (sul do Afeganistão), Asadullah Kha.

Outras 20 pessoas ficaram feridas no ataque, provocado por um terrorista suicida que, numa motocicleta, lançou-se contra um grupo que assistia a uma luta, organizada por ocasião das celebrações da festa muçulmana do sacrifício, explicou Khalid.

Horas antes, por volta das $14 \mathrm{~h} 55$ ( $8 \mathrm{~h} 25$ de Brasília), outro ataque suicida contra um comboio do Exército afegão no centro da cidade de Candahar, antiga área de influência dos talebans afegãos, causou pelo menos dois mortos e 16 feridos, segundo o governador.

O governador de Candahar disse que o atentado suicida de Spinboldak ocorreu nesta tarde quando estava terminando o combate de luta, que tinha reunido um grande público.

Segundo Khalid, há "claros indícios" de que este ataque foi provocado por "terroristas treinados e financiados no Paquistão".

E ontem, outro ataque suicida contra um comboio militar canadense em Candahar matou um diplomata dessa nacionalidade e dois civis afegãos, e feriu 13 pessoas, entre elas três soldados canadenses e várias crianças.

Nos últimos dias, ocorreram vários atos violentos no sul do Afeganistão, apesar do forte inverno que castiga a região e que, normalmente, diminui a violência.

\section{Especial}

Leia o que já foi publicado sobre o Afeganistão

\section{DESTAQUES}

Gripe: Indonésia anuncia $13^{\mathrm{a}}$ vítima da gripe aviária

Irã: Líderes se reúnem para discutir crise com o Irã

Iraque: Helicóptero americano cai ao norte do Iraque

Austrália: Homem sobrevive a ataque de tubarão na Austrália 


\section{Kandahar}

\section{Selbstmordattentäter in Afghanistan töten 24 Menschen}

16. Januar 2006 Zwei Selbstmordattentäter haben am Montag in Afghanistan mindestens 22 weitere Menschen getötet. Bei dem ersten Anschlag in der südafghanischen Stadt Kandahar wurden neben dem Attentäter vier Afghanen getötet. Dem zweiten Selbstmordanschlag in der Provinz Kandahar fielen mindestens 20 afghanische Zivilisten zum Opfer, 20 seien verletzt worden, sagte Provinzgouverneur Asadullah Chalid. Erst am Sonntag zuvor hatte ein Selbstmordattentäter ebenfalls in Kandahar den ranghöchsten kanadischen Diplomaten in dem Land, Glyn Berry, umgebracht.

\section{Isaf: Sicherheitslage nicht schlechter}

Chalid machte das benachbarte Pakistan für den jüngsten Anschlag im Kandahar-Distrikt Spin Boldak verantwortlich. „Hinter dieser feigen und bösen Tat stecken Feinde Afghanistans, die in Pakistan ausgebildet, ausgerüstet und geschützt werden", sagte er.

Trotz einer deutlichen Zunahme von Selbstmordanschlägen in den vergangenen Monaten beharrte die internationale Schutztruppe Isaf am Montag darauf, daß sich die Sicherheitslage in Afghanistan nicht verschlechtert habe. Bei einem der Selbstmordanschläge in der Hauptstadt Kabul kam im vergangenen November auch ein Bundeswehr-Soldat ums Leben.

Im Süden Afghanistans verfolgen von den Vereinigten Staaten geführte Koalitionstruppen Reste der entmachteten Taliban und deren Verbündete vom Terrornetz Al Qaida. Kandahar war früher Hochburg der Taliban unter deren Führer Mullah Omar, der von dort aus als „Oberster Führer der Gläubigen” beinahe das ganze Land beherrschte.

\section{Zum Thema:}

\section{Luftangriff schürt antiamerikanische Stimmung}

Pakistan: Amerikaner jagen Zawahiri

\section{Zehn Tote bei Selbstmordanschlag - Botschafter unverletzt}




\title{
04/12/2006 - 05h23
}

\section{Chávez comemora vitória com ampla vantagem}

\author{
da France Presse, em Caracas \\ da Folha Online
}

Diante de uma multidão reunida debaixo de chuva na frente do Palácio Miraflores, o presidente da Venezuela, Hugo Chávez, proclamou nesta segunda-feira sua vitória eleitoral e atacou os Estados Unidos. A divulgação do primeiro boletim oficial parcial lhe deu uma ampla vantagem sobre o adversário, Manuel Rosales, que já reconheceu a derrota. O primeiro boletim divulgado pelo CNE (Conselho Nacional Eleitoral) apontava, com $78,31 \%$ dos votos apurados, a vitória de Chávez com $61,35 \%$ dos votos, contra 38,39\% de Rosales. Segundo a diretora do CNE, Tibisay Lucena, Chávez obtinha 5.936.141 votos contra 3.715.292 do adversário, de um total de 9.811 .333 de votos apurados.

Chávez disse que sua reeleição "é outra derrota para o diabo que pretende dominar o mundo", numa referência ao presidente americano, George W. Bush.

O presidente, reeleito para mais seis anos de mandato, afirmou que "a Venezuela nunca será colônia americana nem de ninguém". Mesmo assim, fez questão de separar a oposição a George W. Bush do antiamericanismo, ao enviar "ao povo americano nossas saudações e nossa solidariedade". Também mandou "uma saudação solidária e comprometida a todos os povos da América Latina e o Caribe".

Chávez aproveitou para dedicar sua vitória "também ao povo cubano e ao presidente Fidel Castro" e contou já ter recebido telefonemas de felicitações do presidente argentino, Néstor Kirchner, e de sua mulher, assim como do presidente recém-eleito do Equador, Rafael Correa. "Está tudo consumado, (é) a grande vitória da Revolução Bolivariana", disse o presidente. Para os partidários, a maioria de roupa vermelha e agitando bandeiras nacionais, Chávez afirmou que "o reino do socialismo é o reino do futuro venezuelano". "Vocês votaram no socialismo do século 21, a nova democracia socialista", disse Chávez, pedindo que "ninguém tenha medo do socialismo".

Sem se dirigir ao candidato derrotado, nem aos que votaram nele, afirmou apenas: "minha mensagem vai dirigida à Nação, toda, sem exceções de qualquer tipo".

O presidente declarou ainda "uma guerra de morte contra a corrupção" e se pronunciou por uma "verdadeira moral bolivariana, cristã, socialista".

\section{"A luta continua"}

O rival de Chávez também reconheceu a derrota. "Hoje nos venceram, mas a luta continua", afirmou Manuel Rosales, diante de seguidores que gritavam "Fraude, fraude!".

Em discurso, Rosales não questionou sua derrota, mas disse acreditar que o resultado final não mostre uma vantagem chavista tão ampla quanto a divulgada no primeiro boletim eleitoral.

"Muitos gostariam que eu mentisse (...) mas a verdade é que, mesmo com uma margem mais estreita [do que o percentual anunciado no primeiro boletim eleitoral oficial], nos venceram hoje, mas continuaremos na luta", disse.

"Em nome desses milhões de venezuelanos, agradeço a todo o povo por seu comportamento cívico, democrático, ativo, em toda a Venezuela", completou Rosales.

\section{Sistema eleitoral}

O sistema eleitoral da Venezuela prevê um único turno para as eleições presidenciais. 
Antes das eleições, Chávez havia prometido, caso vencesse, promover uma reforma para que o chefe de Estado possa exercer mais de dois mandatos consecutivos, como dita a atual lei venezuelana.

A oposição rejeita a intenção de Chávez, vista como barreira para a democracia no Executivo.

\section{Especial}

Leia o que já foi publicado sobre Hugo Chávez

Leia o que já foi publicado sobre Manuel Rosales

Leia o que já foi publicado sobre a eleição na Venezuela

Leia a cobertura completa da eleição na Venezuela 


\section{Präsidentenwahl in Venezuela}

\section{Klarer Sieg für Chávez}

04. Dezember 2006. Bei der Präsidentenwahl in Venezuela hat Amtsinhaber Hugo Chávez einen klaren Sieg errungen. Der Wortführer der radikalen Linken in Lateinamerika kam nach Auszählung von 78 Prozent der Stimmen auf 61 Prozent, wie die Nationale Wahlbehörde am Sonntag abend mitteilte. Oppositionsführer Manuel Rosales lag demnach nur bei 38 Prozent. Rosales gestand seine Niederlage kurz nach Bekanntgabe der Ergebnisse ein.

„Es ist eine weitere Niederlage für den Teufel, der die Welt beherrschen will“, rief Chávez Hunderten von jubelnden Anhängern vor dem Präsidentenpalast in der Hauptstadt Caracas zu. Abermals nannte er den amerikanischen Präsidenten George W. Bush einen „Satan“. Seinen Sieg widmete er dem erkrankten kubanischen Staatschef Fidel Castro. Befürchtungen, die Opposition könnte nach einer Niederlage das Ergebnis nicht anerkennen und zu einem Putsch aufrufen, bestätigten sich zunächst nicht. „Wir geben zu, daß sie uns heute besiegt haben. Aber wir werden diesen Kampf fortsetzen“", sagte Rosales.

\section{„Sozialismus des 21. Jahrhunderts“}

Sollten die Ergebnisse vom Sonntag bestätigt werden, hätte Chávez noch besser als bei seinen Wahlsiegen 1998 und 2000 abgeschnitten. Der fulminante Sieg könnte Chávez' Kampf für einen Pakt lateinamerikanischer Staaten gegen den Einfluß der Vereinigten Staaten in der Region neuen Auftrieb verleihen. Der 52jährige hatte die Wahl zur Abstimmung über seinen „Sozialismus des 21. Jahrhunderts“ erklärt.

Die Abstimmung schließt ein Wahljahr ab, in dem die Machtverhältnisse in Lateinamerika endgültig zugunsten der Linken gekippt sind. Die meisten der 19 spanisch- oder portugiesisch-sprachigen Länder der Region werden nun von dieser Strömung dominiert. Die Mehrheit, darunter so wichtige Länder wie Argentinien und Brasilien, werden jedoch von gemäßigten Politikern regiert. Nur wenige wie eben Venezuela, Bolivien und eventuell Ecuador fahren einen radikalen, von Chávez geprägten Kurs. Sie arbeiten aber weiter mit ausländischen Unternehmen zusammen, lassen die Besitzverhältnisse im Wesentlichen unangetastet und gewährleisten den meisten Beobachtern zufolge weiter die Meinungsfreiheit.

Chávez ist besonders bei der armen Bevölkerung beliebt, weil er einen Großteil der hohen Einnahmen aus dem Ölgeschäft für Sozialausgaben verwendet. 56 Prozent der 27 Millionen Venezolaner leben nach Angaben der Vereinten Nationen unterhalb der Armutsgrenze obwohl das Land weltweit der achtgrößte Erdöl-Exporteur ist.

\section{Washington: Gefahr für die Demokratie}

Kritiker werfen Chávez dagegen vor, den kommunistischen Stil seines kubanischen Verbündeten Fidel Castro zu imitieren und das Land quasi diktatorisch $\mathrm{zu}$ führen. Die Regierung in Washington sieht Chávez deshalb als Gefahr für die Demokratie in Lateinamerika.

Auch Rosales wirft dem ehemaligen Fallschirmjäger vor, seinen Einfluß auf die wichtigsten Institutionen seit seiner ersten Wahl 1998 ständig ausgebaut zu haben. So verweist er zum Beispiel auf die Massenentlassungen bei der staatlichen Ölfirma Pdvsa nach einem gegen Chávez gerichteten Generalstreik. Außerdem führt er den Plan des Präsidenten an, die Begrenzung seiner Amtszeit in der Verfassung aufzuheben. Im Parlament sitzen nur noch Anhänger des Präsidenten, allerdings vor allem weil die Opposition die Wahl boykottiert hat. 
Weitere Kritikpunkte des 53jährigen Rosales sind die hohe Kriminalitätsrate in der Hauptstadt Caracas und die Öllieferungen zu vergünstigten Preisen an Kuba.

Zum Thema:

Venezuelas Präsident Chávez vor der Wiederwahl

Hugo Chavez und „Freunde“: Vereint gegen Washington

Ecuador: Correa gewinnt Präsidentenwahl 


\section{7/01/2006 - 12h14}

\section{Ex-presidente alemão Johannes Rau morre aos 75 em Berlim}

da Folha Online

O ex-presidente alemão Johannes Rau morreu nesta sexta-feira, aos 75 anos, em seu apartamento em Berlim. A causa da morte não foi imediatamente divulgada, mas ele sofria de vários problemas de saúde nos últimos anos.

Rau era considerado uma dos mais admirados políticos alemães e foi carinhosamente apelidado de "Brother Johannes" (irmão Johannes), por sua proximidade com as pessoas e sua profunda fé.

Durante seu mandato, entre 1999 e 2004, Rau se dedicou a estreitar os laços da Alemanha com Israel --abalados devido ao Holocausto----extermínio de cerca de 6 milhões de judeus por nazistas durante a Segunda Guerra Mundial (1939-1945).

Em 2000, pediu desculpas pelo Holocausto em um discurso emocionado feito em alemão no Parlamento de Israel (Knesset). À época, o presidente alemão disse lutaria para não permitir que a xenofobia e o racismo voltassem a se estabelecer na Europa.

"Eu peço o perdão a Israel pelo que os alemães fizeram, por mim e por minha geração, pelo bem de nossos filhos e netos, cujo futuro eu gostaria de ver lado a lado com as crianças de Israel."

\section{Carreira}

Filho de um pastor protestante, Rau nasceu na cidade de Wuppertal (oeste) em 16 de janeiro de 1931. Ele deixou a escola para trabalhar como jornalista em uma publicação protestante, antes de entrar para a política como membro do Partido Social Democrata.

Em 1969, tornou-se prefeito de Wuppertal e, em 1978, governador do Estado de Renânia do Norte-Westfalia, o mais populoso da Alemanha e o centro industrial do país, cargo que ocupou durante duas décadas.

Apesar disso, Rau teve menos sucesso em sua carreira política nacional. Em 1987, ele foi derrotado pelo conservador Helmut Kohl na disputa ao cargo de chanceler da Alemanha, e não teve sucesso em sua primeira tentativa para o cargo de presidente do país, em 1994. No entanto, ele convenceu seu partido a deixá-lo concorrer novamente, tornando-se o primeiro presidente social-democrata em 25 anos.

Legisladores demonstravam preocupação com a saúde de Rau-- ele teve seu rim esquerdo retirado em 1992 e, em 2000, passou por uma operação para a substituição de uma artéria no estômago.

\section{Polêmica}

Em 2003, Rau defendeu o uso de véus por professoras muçulmanas em escolas alemãs, alegando que, se os trajes islâmicos fossem vetados, símbolos cristãos e judeus também deveriam ser banidos. A posição gerou intensas críticas de políticos da esquerda e da direita. O ex-líder alemão também se posicionou contra as pesquisas científicas na área da genética, afirmando que, no período nazista, experimentos "aterrorizantes" foram realizados. "Quando a dignidade humana é afetada, questões econômicas não devem ser levadas em conta", afirmou. Em 2003, Rau anunciou que não concorreria à reeleição à Presidência. Ele foi substituído, em 2004, pelo atual presidente alemão, o conservador Horst Koehler. Em 1982, aos 51 anos, Rau se casou com Christina Delius, 25 anos mais nova. O casal teve três filhos: Anna, Philip e Laure. 
Com agências internacionais

\section{Especial}

Leia o que já foi publicado sobre Johannes Rau 


\section{Johannes Rau ist tot \\ Er wollte „versöhnen, nicht spalten”}

27. Januar 2006 Der ehemalige Bundespräsident Johannes Rau ist tot. Wie sein Büro mitteilte, starb er am Freitag morgen um 8.30 Uhr im Alter von 75 Jahren. Rau war seit längerem schwer krank. Nach dem Ausscheiden aus dem Amt im Juli 2004 mußte er sich zwei Operationen unterziehen, von denen er sich nicht mehr richtig erholen konnte.

Rau sei am Freitag morgen zuhause im Kreis seiner Familie gestorben, teilte das Büro des früheren Staatsoberhaupts mit. Wenige Tage zuvor hatte Rau wegen seines angegriffenen Gesundheitszustandes seine Teilnahme an der offiziellen Feier zu seinem Geburtstag im Berliner Schloß Bellevue absagen müssen.

Über die Parteigrenzen hinweg wurde der SPD-Politiker als großer Staatsmann gewürdigt, dem Deutschland viel zu verdanken habe (siehe: Politiker aller Lager trauern um Johannes $\underline{\mathrm{Rau}})$.

\section{Fast fünf Jahrzehnte in öffentlichen Ämtern}

Johannes Rau wurde am 16. Januar 1931 in Wuppertal geboren. 1957 trat er in die SPD ein. Im Jahre 1978 wurde Rau mit 47 Jahren zum Ministerpräsidenten des Landes NordrheinWestfalen gewählt und blieb in diesem Amt zwanzig Jahre lang. 1999 wurde Rau schließlich von der Bundesversammlung zum Bundespräsidenten gewählt. Am 1. Juli 2004 löste Horst Köhler ihn in diesem Amt ab.

Damals, als seine lange politische Laufbahn zu Ende ging, hatte Rau im Gespräch nicht zu wehmutsvollem Rückblick geneigt. Fast 46 Jahre lang hatte der Politiker Rau öffentliche Ämter innegehabt - länger als alle anderen Bundespolitiker. Im Juli 1958 rückte der junge Sozialdemokrat in den nordrhein-westfälischen Landtag. Da regierte noch der erste Bundeskanzler der Republik, Adenauer, und es repräsentierte der erste Bundespräsident, Heuss. Der junge Sozialdemokrat hatte sie noch kennengelernt. Da war er 27 Jahre alt.

Noch länger war er der Politik verhaftet. 1952 trat er in die Gesamtdeutsche Volkspartei von Gustav Heinemann ein, die der vormalige CDU- und spätere SPD-Politiker aus Protest gegen die Wiederbewaffnung der Bundesrepublik gegründet hatte. Da war Rau noch keine 22 Jahre alt. Rau hat die Veränderungen der Politik und der sie prägenden Umwelt erlebt. Er suchte zuletzt stets den Eindruck zu vermeiden, als Altvorderer der Auffassung zu sein, früher sei alles besser, gar golden gewesen - habe es also bessere Redner, inhaltsvollere Debatten und eine konsistentere Politik gegeben.

\section{Kritik an kurzatmiger Politik}

Der Umgang der Politiker untereinander und innerhalb der Parteien hatte sich nach seiner Auffassung nicht wesentlich verändert. Er sei nicht härter als früher. Doch sah Rau auch die Veränderungen. Die die Politiker umgebenden Medien mag er als eine Ursache sehen. Politik sei dadurch kurzatmiger geworden, sagte er. Hin und wieder beklagte Rau, daß die politischen Auseinandersetzungen nicht im Parlament ausgetragen würden, sondern daß die Kontrahenten lieber vor Kameras und in Talk-Shows das sagten, was sie zu sagen hätten.

Doch war er erfahren genug zu wissen, daß die Politik nicht immer und überall die Hoheit hat, die Mittel ihrer Kommunikation selbst auszuwählen. Er kann das in die Formel kleiden, „wahrscheinlich” hätten die Politiker auf die veränderten Umstände zu reagieren. Rau gehörte 
seit je zu jenen Politikern, die ihr Urteil lieber in Bildern als in zugespitzter Analyse öffentlich machen. Doch kam die landesväterliche Attitüde, die er schon als Ministerpräsident von Nordrhein-Westfalen pflegte, nicht ohne eine klare und entschiedene Sicht der Dinge aus.

\section{Rede vor der Knesset}

Sein altes Wahlkampfmotto „Versöhnen statt spalten” hatte er nicht als Meinungslosigkeit verstehen wollen. Der Innenpolitiker hatte sich mehr als früher der Außenpolitik zuzuwenden. Er suchte Akzente zu setzen: Zweimal besuchte er Afrika; in China sprach er über Menschenrechte. Als erstes deutsches Staatsoberhaupt redete er vor der Knesset in Jerusalem - das war am Anfang seiner Amtszeit - und vor dem polnischen Parlament - das war an deren Ende.

Die schwierigste Entscheidung seiner Zeit als Bundespräsident betraf seine Unterschrift unter das Einwanderungsgesetz. Dem Inhalt stimmte er zu; in vielen Reden hatte er Parteien und gesellschaftliche Gruppen aufgerufen, an einem solchen Vorhaben zu arbeiten. Von der Form, wie es im Bundesrat zunächst verabschiedet wurde, war er dann aber entsetzt. Rau mag die Gefahr gesehen haben, daß nicht bloß er als Person, sondern das Amt des Bundespräsidenten auf eine ungebührliche Weise in den Parteienstreit hineingezogen würde - gleich wie er sich verhielte.

Das Gesetz zu unterschreiben und zugleich die Empfehlung auszusprechen, es solle dessen verfassungsmäßiges Zustandekommen überprüft werden, war der Ausweg für ihn. Die Umstände machten sein Amtsverständnis deutlich. Rau hatte nicht das Selbstverständnis von sich, er sei der erste Angestellte des Staates, also eine Art Vorstandsvorsitzender einer „Deutschland AG”. Er sah das Präsidentenamt als staatliche Institution an. Auf begrenzte Zeit sei der Amtsträger das Staatsoberhaupt. Rau hatte schon als Ministerpräsident das Empfinden, daß auf das Amt bezogene Regeln einzuhalten seien.

\section{Kritik in letzter „Berliner Rede”}

Rau hat sich in seiner letzten „Berliner Rede” kritisch mit den Eliten in Politik, Wirtschaft und Gesellschaft auseinandergesetzt. „Untergangsszenarien und Apokalypsen” würden verbreitet, das Land werde wie kein anderes schlechtgeredet, und es fehle an Vertrauen.

Auch sah er, daß es der Politik schwerfalle, Ziele und Orientierungen zu vermitteln. Adressaten pflegte er nicht zu nennen. Er sah Elemente der Politkverdrossenheit, die Demokratie in Deutschland hielt er aber für stabil. Rau hatte gesagt, von Anfang an nur eine Amtszeit als Bundespräsident angestrebt zu haben, auch wenn er zwischenzeitlich von „Anfechtungen” nicht frei gewesen sei.

Zum Thema:

Politiker aller Lager trauern um Johannes Rau

Die Bundespräsidenten: Von Heuss bis Köhler 


\section{Grupo extremista Hamas vence eleições legislativas palestinas}

\section{da Folha Online}

O grupo extremista palestino Hamas conquistou a maioria absoluta nas eleições legislativas palestinas desta quarta-feira, informaram membros do próprio Hamas e do partido governista Fatah.

Após o anúncio, o primeiro-ministro palestino, Ahmed Korei, renunciou ao cargo. $O$ resultado contraria as expectativas pela permanência do Fatah no poder. Uma pesquisa de boca-de-urna divulgada na noite de ontem indicava que o Fatah teria conquistado 58 cadeiras do Parlamento, contra 53 do Hamas. Segundo o Hamas, o grupo conquistou 75 das 132 cadeiras do novo Parlamento. O Fatah afirma que o grupo extremista obteve 70 cadeiras-número que já seria suficiente para garantir ao Hamas a maioria no Parlamento.

O Fatah controla a atual assembléia, compostas por 88 membros. A nova lei eleitoral reformulada pelo presidente da ANP (Autoridade Nacional Palestina), Mahmoud Abbas, aumentou o número de cadeiras para 132.

Nas eleições desta quarta-feira, 66 legisladores foram escolhidos por distrito e outros 66 por uma lista nacional.

A participação foi alta na votação, quase $78 \%$ do 1,3 milhão de eleitores compareceram às urnas. Mais de 13 mil policiais foram destacados para garantir a segurança nos postos eleitorais. Não houve registro de incidentes.

\section{Resultados}

Os resultados-- ainda não-oficiais-- apontam que o Hamas venceu em quase todos as 16 seções eleitorais na Cisjordânia e em Gaza, particularmente no distrito de Jerusalém, onde o grupo teria conquistado as quatro cadeiras reservadas a muçulmanos no Parlamento. Outras duas cadeiras são reservadas a legisladores cristãos.

De acordo com os resultados parciais, o Hamas obteve as nove cadeiras reservadas ao distrito de Hebron, quatro das cinco cadeiras em Ramallah e a maioria das cadeiras em Nablus, Jenin, Qalqilyah, Tulkarem e Salfit.

$\mathrm{Na}$ faixa de Gaza, o Hamas conquistou todas as cadeiras no norte, na Cidade de Gaza e no distrito de Dir al Balah. O grupo ficou com quatro das cinco cadeiras em Khan Yunis. A quinta cadeira ficou com Mohammed, do Fatah, que conquistou a maioria das cadeiras em Rafah.

O resultado oficial deve ser divulgado às $19 \mathrm{~h}$ (15h de Brasília) desta quinta-feira.

\section{Negociações}

Seguidores do Hamas foram às ruas para celebrar a vitória. Em Rafah, ao sul de Gaza, partidários do grupo atiravam para o alto e entregavam balas para comemorar o resultado. Outros buzinavam e acenavam com bandeiras do movimento pelas janelas dos veículos. Um governo do Hamas, sem o Fatah atuando como força moderada, prejudicaria os esforços de Abbas para a retomada das negociações de paz com Israel. O grupo extremista-- que realizou dezenas de ataques contra israelenses e prega a destruição do Estado de Israel---se opõe às negociações e se recusa a abandonar as armas.

O legislador do Fatah Saeb Erekat afirmou nesta quinta-feira que seu partido não deseja fazer 
parte de um governo controlado pelo Hamas. "Nós formaremos uma oposição e reestruturaremos o partido", afirmou.

No entanto, Nabil Shaath, outro membro do Fatah, disse que seu partido tomará uma decisão a respeito até o final do dia.

\section{Reação}

Autoridades israelenses se recusaram a comentar a vitória do Hamas, mas altos membros da segurança israelense se reuniram nesta quinta-feira para discutir os resultados. O primeiroministro interino, Ehud Olmert, marcou uma reunião com membros do governo, que deve acontecer hoje.

A secretária de Estado americana, Condoleezza Rice, afirmou nesta quinta-feira que a posição dos EUA em relação ao Hamas "não mudou", apesar de o grupo ter vencido as eleições palestinas. Os EUA e a Europa consideram o Hamas uma organização terrorista.

"Como já dissemos, não é possível manter um pé na política e outro no terrorismo. Nossa posição em relação ao Hamas não mudou", afirmou Rice por videoconferência no Fórum Econômico Mundial, que acontece na Suíça.

Rice admitiu que as eleições "foram justas" e tiveram "alta participação". O primeiro-ministro italiano, Silvio Berlusconi, qualificou a vitória do Hamas como um resultado "muito, muito ruim."

Com agências internacionais

\section{Leia mais}

Eleições parlamentares palestinas terminam em Gaza e Cisjordânia

Partido governista Fatah reconhece derrota em eleições palestinas

\section{Especial}

Leia cobertura completa sobre as eleições palestinas

Leia o que já foi publicado sobre as eleições palestinas 


\section{Nach Wahlsieg der Hamas Fatah-Regierung tritt zurück}

26. Januar 2006 Die israelfeindliche Hamas-Bewegung hat aller Voraussicht nach die palästinensische Parlamentswahl gewonnen und wird die künftige Regierung stellen. Schon vor der für den frühen Abend angekündigten Bekanntgabe des offiziellen Wahlergebnisses trat das von der Fatah geführte Kabinett zurück. Ministerpräsident Ahmed Qurei sagte am Donnerstag morgen: „Die Hamas sollte die neue Regierung bilden, wenn sich ihr Sieg bestätigt."

Der Friedensprozeß droht durch den Sieg der Hamas zum Stillstand zu kommen. Israel und die Vereinigten Staaten haben angekündigt, nicht mit einer Regierung unter Führung der Hamas zusammenzuarbeiten. „Unsere Haltung zur Hamas ist sehr klar”, sagte ein Sprecher des amerikanischen Präsidenten George W. Bush am Mittwoch abend. „Wir geben uns nicht mit der Hamas ab."

\section{Dringlichkeitssitzung in Israel}

Das israelische Sicherheitskabinett kam am Donnerstag zu einer Dringlichkeitssitzung zusammen, nachdem sich das Wahlergebnis abzeichnete. Noch vor wenigen Tagen hatte Israel die Teilnahme der Hamas an der Wahl scharf kritisiert. „Es ist sehr schwer, an irgendeinen Fortschritt zu glauben, wenn die Palästinenser-Regierung von einer Mörderbande übernommen wird”, sagte Minister Zachi Hanegbi. (Siehe auch: Sieg der Hamas: „Wie in Deutschland 1933")

Die militante islamistische Hamas bestätigte am Donnerstag ihre feindliche Haltung gegenüber Israel: „Verhandlungen oder eine Anerkennung des jüdischen Staates stehen nicht auf unserer Agenda", sagte Muschir al Masri, der in seinem Wahlbezirk im Norden des Gazastreifens bei der Wahl am Mittwoch ein Mandat erringen konnte. „Unser Sieg zeigt, daß der Weg der Hamas der richtige ist."

\section{„Wir wollen eine politische Partnerschaft”}

Den Wahlsieg errang die Hamas aus dem Stand. Die Wahl 1996 hatte die Gruppe noch aus Protest gegen die damals laufenden Nahost-Verhandlungen boykottiert. Sie hat sich 1987 während des ersten Palästinenser-Aufstands gegründet und kämpft für eine Zerstörung Israels. Anstelle der von der Fatah befürworteten Zwei-Staaten-Lösung reklamiert sie auch das gesamte israelische Gebiet für einen Staat Palästina. Die militante Gruppe ist für etwa 60 Selbstmordattentate in Israel verantwortlich, hat sich im vergangenen Jahr aber an eine Waffenruhe gehalten.

Masri bekräftigte den Willen der Hamas zu einer Koalition mit der Fatah-Bewegung. „Wir wollen eine politische Partnerschaft”, sagte er. „Unsere Partei strebt nach einer Einigung des palästinensischen Volkes, dafür ist eine politische Partnerschaft sehr wichtig." Dagegen sagte ein ranghoher Vertreter der Fatah-Bewegung am Donnerstag, man lehne eine Beteiligung an einer Koalitionsregierung mit der Hamas ab. Der palästinensische Chefvermittler Sajeb Erakat, der selbst der bislang regierenden Fatah angehört, sagte am Donnerstag nach einem Treffen mit Präsident Mahmud Abbas, die Fatah-Partei werde in die Opposition gehen. „Wir werden eine loyale Opposition sein und die Partei wieder aufbauen." 


\section{Absolute Mehrheit wahrscheinlich}

Nach vorläufigen Ergebnissen konnte die radikalislamische Hamas-Bewegung die absolute Mehrheit erringen. Spitzenkandidat Ismail Hanijeh sagte, die Hamas habe mindestens 75 der 132 Sitze gewonnen. Er bezog sich auf Angaben von Hamas-Anhängern, die an der Auszählung beteiligt waren. Mehr als die Hälfte der Stimmen sei bereits ausgezählt.

Aus Kreisen der Wahlkommission verlautete, nahezu alle der 66 Direktmandate gingen an die Hamas. Deren Führer Mahmud Sahar sagte, seine Partei werde nach Bekanntgabe der Ergebnisse „klare Antworten auf die Frage der Regierungsbildung” geben.

\section{Kritik an der Fatah: Korruption und Vetternwirtschaft}

Das Nahost-Quartett aus Amerika, der Europäische Union (EU), den Vereinten Nationen (UN) und Rußland will am Montag über Konsequenzen aus der Wahl beraten. Es hat vor drei Jahren einen Fahrplan vorgelegt, der zu einer Wiederaufnahme der Friedensverhandlungen führen soll. Ein Ende der Gewalt gilt als eine Voraussetzung dafür.

Die Hamas wurde jedoch nicht nur für ihre radikale Haltung gegenüber Israel gewählt. Sie profitierte laut Umfragen auch in hohem Maße davon, daß sich die Fatah in den zwölf Jahren, die sie seit der Bildung der Palästinenser-Regierung an der Macht ist, verschlissen hat. Sie wird für Korruption und Vetternwirtschaft kritisiert, für Mißwirtschaft und interne Machtkämpfe zwischen der noch von Jassir Arafat ausgewählten alten Führungsgarde und jungen Reformkräften, die ihren Interessen auch mit Waffengewalt nachhelfen. Dagegen genießt die streng religiöse Hamas den Ruf, gegen Korruption gefeit und moralisch zuverlässig zu sein. Sie baute zudem in den Jahren der Besatzungszeit vor allem im Gazastreifen ein soziales Netz auf, das vielen verarmten Familien unter die Arme greift.

Zum Thema:

\section{Video: Hamas gewinnt Palästinenser-Wahl}

Sieg der Hamas: „Wie in Deutschland 1933”

Video: Die Palästinenser wählen

\section{Palästinenser wählen Parlament}

Luftröhrenschnitt bei Scharon - Operation erfolgreich verlaufen 
14/01/2006 - 17h32

Juiz do ex-ditador do Iraque Saddam Hussein apresenta carta de renúncia

da Associated Press, em Bagdá

Rizgar Mohammed Amin, o juiz-chefe do caso Saddam Hussein, o ditador que governou o Iraque de 1979 a 2003, apresentou sua carta de renúncia, segundo um oficial da corte, que repassou a informação à Associated Press sob condição de anonimato. Ainda não há informações se a decisão será aceita.

O promotor-chefe do caso Saddam, Jaafar al-Mousawi, afirmou que a renúncia de Amin --se aceita pela corte-- não afetaria a continuidade do julgamento porque o juiz seria rapidamente substituído.

No caso de Saddam, o juiz ficou desanimado pelo jeito que foi atacado por críticos na imprensa, que o acusavam de perder o controle do julgamento. Saddam teria parte da culpa, já que durante o julgamento por um massacre ocorrido em 1982, ele se recusou a comparecer a uma das sessões, reclamou de torturas e rezou no meio do julgamento quando o júri não permitiu um recesso.

Amin é um curdo que antes do julgamento de Saddam era virtualmente desconhecido em sua região de origem. Ele preside um painel de cinco juízes que acompanham o julgamento de Saddam e que deve pronunciar o veredicto. O julgamento começou em outubro e está programado para terminar no próximo dia 24.

\section{Especial}

$\underline{\text { Leia o que já foi publicado sobre o julgamento de Saddam Hussein }}$ 
Irak

Vorsitzender Richter im Saddam-Prozeß zurückgetreten

14. Januar 2006. Der Vorsitzende Richter im Prozeß gegen den früheren irakischen Machthaber Saddam Hussein hat seinen Rücktritt eingereicht. Dies sagte ein Gerichtsmitarbeiter am Samstag Ob der Rücktritt angenommen wurde, war zunächst nicht bekannt.

Rizgar Muhammad Amin steht dem fünfköpfigen Gremium vor, vor dem sich Saddam Hussein und sieben Mitangeklagte seit dem 19. Oktober 2005 verantworten müssen. Der nächste Verhandlungstermin ist für den 24. Januar anberaumt. Amin habe sich über Angriffe in den Medien geärgert, in denen Kritiker ihm vorwarfen, er habe die Kontrolle über den Prozeß verloren, sagte der Gerichtsmitarbeiter weiter.

Saddam Hussein hat in dem Verfahren die Richter beschimpft, erschien zu einer Sitzung gar nicht und betete offen im Gerichtssaal, als der Richter keine Pause genehmigte. Saddam Hussein und seine Mitangeklagten müssen sich wegen eines Massakers in der Stadt Dudschail nördlich von Bagdad verantworteten. Dort wurden 1982 mehr als 140 Schiiten umgebracht.

Zum Thema:

Saddam-Prozeß: Richter Amin greift durch

Video: Saddam erscheint nicht vor Gericht

Saddam Hussein erscheint nicht vor Gericht

Irak: Tumult und Protest bei Saddam-Prozeß 
16/01/2006 - 07h30

\section{Líderes se reúnem em Londres para discutir crise com o Irã}

\section{da Efe}

Diplomatas britânicos se reunirão nesta segunda-feira em Londres com seus colegas da Alemanha, França, EUA, Rússia e China para discutir a questão iraniana, após a decisão do país de retomar suas atividades nucleares.

As conversas serão a portas fechadas e a imprensa não terá acesso às mesmas e, em princípio, também não está prevista uma entrevista coletiva posterior.

As principais potências do mundo querem debater os próximos passos a seguir depois que o Irã decidiu, na semana passada, romper os lacres de algumas de suas usinas para retomar seus programas de pesquisa e desenvolvimento nuclear.

Londres, Paris e Berlim pediram uma reunião urgente da AIEA (Agência Internacional de energia Atômica), que deverá elaborar um relatório e pode remeter o caso ao Conselho de Segurança das Nações Unidas.

O Alto Representante da Política Externa e de Segurança da União Européia (UE), Javier Solana, insistiu ontem em Londres que "por enquanto, não está na mente de ninguém uma intervenção militar contra o Irã".

\section{Especial}

Leia o que já foi publicado sobre a questão nuclear iraniana 


\section{Atomstreit \\ IAEA-Chef Baradei schließt Gewalt gegen Iran nicht aus}

16. Januar 2006 Der Chef der Internationalen Atomenergiebehörde IAEA schließt auch Gewalt nicht aus, um Iran im Streit über dessen Atomprogramm zur völligen Offenheit zu zwingen. In einem am Sonntag veröffentlichten Interview mit der amerikanischen Zeitschrift „Newsweek” sagte Mohammed el Baradei: „Diplomatie ist nicht nur Reden. Diplomatie braucht auch Druckmittel, und, in extremen Fällen, Gewalt."

El Baradei sagte, er sei nicht bereit, die Iran gesetzte Frist zur vollen Kooperation, die am 6. März abläuft, zu verlängern. „Wir müssen alles tun, um die Einhaltung der Regeln durch Überzeugung zu erreichen. Wenn das nicht funktioniert, muß man sie durchsetzen. Das muß der letzte Ausweg bleiben, aber manchmal muß man ihn beschreiten."

\section{„Lackmus-Test in den nächsten paar Wochen”}

Die IAEA soll feststellen, ob das jahrelang geheimgehaltene Atomprogramm Irans wie von Teheran versichert nur friedlichen Zwecken dient oder, wie von den Vereinigten Staaten geargwöhnt, waffenfähiges Material produzieren soll. Dazu müßten noch Bodenproben untersucht und bestimmte Wissenschaftler befragt werden, sagte El Baradei.

Auf die Frage, ob Iran in dem Konflikt auf Zeit spielt, um eine Bombe zu bauen, antwortete El Baradei: „Das ist der Grund, warum ich sage, daß es in den nächsten paar Wochen zu einem Lackmus-Test kommt." Er schließe nicht aus, daß Iran ein weiteres, noch geheimer gehaltenes Atomwaffenprogramm betreibe, das von den der IAEA bekannten Aktivitäten getrennt sei. „Wenn sie das Atommaterial haben und wenn sie ein paralleles Waffenprogramm unterhalten, dann sind sie wirklich nicht weit - ein paar Monate - von einer Waffe entfernt." In seinen bisherigen Berichten für die IAEA hat El Baradei festgestellt, es gebe keinen Beweis dafür, daß der Iran Arbeiten mit Bezug zu Atomwaffen betreibe.

\section{McCain: schwierigste Lage seit dem Kalten Krieg}

In Amerika sagte der einflußreiche republikanische Senator John McCain, die Vereinigten Staaten müßten auf einen Militäreinsatz gegen Iran vorbereitet sein. „Die militärische Option ist die letzte Option, aber man kann sie nicht vom Tisch wischen”, sagte McCain am Sonntag (Ortszeit) im Fernsehsender CBS. Mit der Entwicklung in Iran sei die schwerwiegendste Lage entstanden, „mit der wir seit dem Ende des Kalten Krieges konfrontiert waren, ausgenommen den ganzen Krieg gegen den Terror”.

Zwar seien die Vereinigten Staaten durch ihren Militäreinsatz im Irak ,in hohem Maße” gebunden, sagte McCain. „Aber das bedeutet nicht, daß wir keine militärischen Optionen haben." Zunächst solle Washington aber versuchen, die iranische Führung in die Schranken zu weisen, indem sie demokratische Bewegungen von Regierungsgegnern unterstütze, sagte der Senator, der als möglicher Kandidat bei der nächsten Präsidentschaftswahl gilt. „Die iranische Bevölkerung ist unter diesen Mullahs nicht glücklich.” Die Regierung habe das Volk unterdrückt. „Wir müssen viel mehr tun, um das Demokratiestreben in Iran zu unterstützen."

\section{Blix: Sicherheitsrat noch nicht einschalten}


An diesem Montag ist die Suche nach einer diplomatischen Lösung im Atomstreit mit Iran Thema eines Treffens in London. An der Begegnung nehmen nach Angaben des britischen Außenministeriums ranghohe Vertreter der drei EU-Staaten Deutschland, Frankreich und Großbritannien sowie aus den Vereinigten Staaten, China und Rußland teil. Dabei geht es auch um die Frage, ob der UN-Sicherheitsrat in den Konflikt eingeschaltet wird.

Der frühere IAEA-Chef Hans Blix hat unterdessen davor gewarnt, den Sicherheitsrat jetzt zu befassen. Der Westen müsse sich vielmehr darum bemühen, Iran in die internationale Gemeinschaft „zurückzuholen”, sagte Blix am Montag dem britischen Rundfunksender BBC. Die derzeitigen Überlegungen für Beratungen im Sicherheitsrat brächten einen ,immer dramatischeren Ton" in den Konflikt.

\section{Iran droht mit höherem Ölpreis}

Am Wochenende hatte Iran die Europäische Union zur Rückkehr an den Verhandlungstisch aufgefordert. Zugleich stellte sich das Parlament in Teheran hinter die harte Linie von Präsident Mahmud Ahmadineschad. Sollten die Vereinigten Staaten und die EU den Fall vor den Sicherheitsrat bringen, werde das Parlament darauf bestehen, die Kontrollen iranischer Atomanlagen durch Inspekteure der IAEA in Wien zu stoppen.

Am Sonntag drohte die Führung in Teheran indirekt mit einer Erhöhung des Ölpreises. Sanktionen gegen sein Land könnten zu einer Ölkrise führen, sagte Finanzminister Dawud Danesch-Dschafari.

Zum Thema:

FAZ.NET-Spezial: Atomstreit mit Iran

\section{Ahmadineschad besteht auf Atomforschung}

Video: Bush und Merkel wollen Iran-Konflikt diplomatisch lösen 


\section{0/01/2006 - 15h19}

\section{Ministro de Israel acusa Irã e Síria de financiar atentados}

da Efe, em Jerusalém

O ministro da Defesa de Israel, Shaul Mofaz, acusou o Irã de financiar e a Síria de ter planejado o atentado que deixou 26 feridos em Tel Aviv nesta quinta-feira, e disse que entregou as provas aos Estados Unidos, à União Européia (UE) e ao Egito.

"Israel tem provas decisivas que mostram que o ataque em Tel Aviv foi resultado direto do "eixo do mal" [expressão usada pelo presidente George W. Bush para designar Iraque, Irã e Coréia do Norte, países acusados pelos EUA de desenvolver armas de destruição em massa e de colaborar com terroristas] que opera entre o Irã e a Síria", disse o ministro em declarações divulgadas nesta sexta-feira por diversos meios israelenses.

Segundo Mofaz, "o Irã proporcionou o dinheiro, e o quartel-general do grupo terrorista em Damasco (Síria) dirigiu a operação dos agentes em Nablus, com instruções".

O ministro israelense ressaltou que o ataque ocorreu enquanto o presidente do Irã, Mahmoud Ahmadinejad, reunia-se em Damasco com seu colega sírio, Bashar al Assad, em um encontro que chamou de "a cúpula do terrorismo".

\section{"Eixo do terrorismo}

"Damasco é o único lugar no qual ainda se dá boas-vindas ao presidente iraniano", disse o ministro, acrescentando que "o eixo do terrorismo sírio-iraniano não é um problema privado de Israel".

Segundo o jornal israelense "Haaretz", o objetivo de apresentar aos EUA, à UE e ao Egito as provas contra o regime de Teerã é pressionar para que o Conselho de Segurança da ONU (Organização das Nações Unidas) imponha sanções ao Irã devido à retomada de seu programa nuclear.

Apesar de o Irã negar que tenha intenção de desenvolver um arsenal nuclear, Israel considera que as investigações de Teerã sobre energia atômica são uma ameaça.

Ao menos 13 das 26 pessoas que ficaram feridas no atentado em Tel Aviv continuam hospitalizadas. Uma delas está em estado de média gravidade, enquanto as outras tiveram ferimentos leves ou estão em estado de choque.

O suicida, um jovem palestino procedente da cidade de Nablus (Cisjordânia), foi o único a morrer no ataque, ao detonar os explosivos que tinha presos ao corpo em um restaurante perto da antiga estação central de ônibus de Tel Aviv, onde se concentram vários trabalhadores estrangeiros.

Segundo testemunhas citadas por "Haaretz", o suicida se fez passar por um vendedor ambulante de lâminas de barbear.

A polícia israelense informou que o jovem detonou os explosivos quando estava no banheiro do restaurante, possivelmente de forma acidental enquanto preparava a carga.

Trata-se do primeiro atentado suicida em mais de um ano cometido em Israel por um palestino de Nablus, cidade que permaneceu sob ataque militar israelense durante a maior parte dos últimos cinco anos.

\section{Jihad Islâmico}


O atentado foi reivindicado pelo Jihad Islâmico, organização que se inspira na revolução islâmica iraniana e que cometeu vários ataques palestinos contra Israel durante no ano passado, ao assumir a autoria dos seis atentados suicidas desde fevereiro passado.

Após o atentado, Mofaz ordenou que as forças de segurança continuassem com as intensas operações que realiza há meses na busca de ativistas dessa organização na Cisjordânia.

Além disso, a polícia aumentou o nível de alerta em todo o país, com um maior número de postos de controle e de agentes em locais de concentração de pessoas.

Israel criticou o governo palestino alegando indiferença na hora de tomar medidas para evitar os ataques suicidas contra Israel. A ANP (Autoridade Nacional Palestina) condenou o ataque, considerando uma tentativa de sabotagem contra as eleições legislativas palestinas do próximo dia 25 , que não terá a participação do Jihad Islâmico.

\section{Especial}

Leia cobertura completa sobre o conflito no Oriente Médio Leia o que já foi publicado sobre o programa nuclear iraniano 


\section{Naher Osten}

\section{Mofaz: Anschlag war das Werk Irans und Syriens}

20. Januar 2006 Der israelische Verteidigungsminister Mofaz hat Syrien und Iran für den jüngsten Selbstmordanschlag in Tel Aviv verantwortlich gemacht, bei dem am Donnerstag der Attentäter ums Leben kam und 20 Personen zum Teil schwer verletzt wurden. Mofaz wurde am Freitag mit den Worten zitiert, Syrien habe die Tat geplant, und Iran habe sie bezahlt.

Er sprach von einer Achse des Terrors zwischen Iran und Syrien. Mofaz kündigte Angriffe auf Stellungen des Islamischen Dschihads im Südlibanon an, der sich des Anschlags bezichtigt hatte. Es gebe „klare Beweise” für die Verwicklung Syriens und Irans, wurde Mofaz zitiert. Israel werde diese Beweise an Washington und die Europäische Union weiterleiten. Der iranische Präsident Ahmadineschad kam am Freitag in Syrien mit dem Führer der Terrorgruppe Islamischer Dschihad zusammen, die sich des Anschlags in Tel Aviv bezichtigt hatte.

Zum Thema:

Verletzte bei Anschlag auf Busbahnhof in Tel Aviv 


\section{6/01/2006 - 08h13}

\section{Resultados apontam vitória do Hamas em eleições palestinas da Folha Online}

Resultados parciais das eleições legislativas palestinas indicam a vitória do grupo extremista palestino Hamas-- que, aparentemente, conquistou a maioria absoluta após ganhar na maior parte das seções eleitorais do pleito.

Após o anúncio, o primeiro-ministro palestino, Ahmed Korei, renunciou ao cargo. Mais de $70 \%$ dos palestinos compareceram às urnas.

Uma pesquisa de boca-de-urna divulgada na noite de ontem indicava que o Fatah teria conquistado 58 cadeiras do Parlamento, contra 53 do Hamas.Os resultados-- ainda nãooficiais-- apontam que o Hamas venceu em quase todos as 16 seções eleitorais na Cisjordânia e em Gaza, particularmente no distrito de Jerusalém, onde o grupo teria conquistado as quatro cadeiras reservadas a muçulmanos no Parlamento. Outras duas cadeiras são reservadas a legisladores cristãos.

O resultado oficial deve ser divulgado ainda nesta quinta-feira. O Parlamento palestino é composto por 132 cadeiras. Nas eleições desta quarta-feira, 66 legisladores foram escolhidos por distrito e outros 66 por uma lista nacional.

De acordo com os resultados parciais, o Hamas obteve as nove cadeiras reservadas ao distrito de Hebron, quatro das cinco cadeiras em Ramallah e a maioria das cadeiras em Nablus, Jenin, Qalqilyah, Tulkarem e Salfit.

$\mathrm{Na}$ faixa de Gaza, o Hamas conquistou todas as cadeiras no norte, na Cidade de Gaza e no distrito de Dir al Balah. O grupo ficou com quatro das cinco cadeiras em Khan Yunis. A quinta cadeira ficou com Mohammed, do Fatah, que conquistou a maioria das cadeiras em Rafah.

"O Hamas conquistou mais de 70\% das cadeiras na Cisjordânia e na faixa de Gaza, o que nos dá mais de 50\% dos votos", afirmou o líder do grupo, Ismail Haniyah, nesta quinta-feira. Haniyah afirmou que os números são baseados em contagens iniciais de representantes do Hamas em postos eleitorais.

\section{Atraso}

A Comissão Eleitoral Palestina informou que os resultados oficiais, que seriam divulgados às 9h (5h de Brasília) só serão conhecidos às 19h (15h de Brasília). Não houve explicação oficial para o atraso.

Tanto o Fatah quanto o Hamas reivindicaram a vitória e celebraram nas ruas. A Cidade de Gaza e a região da Cisjordânia ficaram repletas de carros que buzinavam e centenas de palestinos que festejavam a vitória.

A votação aconteceu sem incidentes nesta quarta-feira, quando 13 mil policiais foram destacados para garantir a segurança da população.

Os postos eleitorais foram fechados às $19 \mathrm{~h}$ (15h de Brasília) e a participação da população foi de 77,7\%, segundo a Comissão Eleitoral. Em Gaza, 85\% dos palestinos foram às urnas, contra 74\% na Cisjordânia.

\section{Abbas}

Após votar em Ramallah, nesta quarta-feira, o presidente da Autoridade Nacional Palestina (ANP), Mahmoud Abbas, se disse "feliz" com as eleições. "Estamos tão felizes com a 
realização das eleições. Até agora, elas está correndo muito bem e esperamos que terminem sem incidentes", afirmou.

Abbas disse ainda que o governo palestino estava "pronto" para retomar as negociações de paz com Israel, mesmo que o Hamas passasse a integrar o novo Parlamento.

"Estamos prontos para negociar", disse Abbas à imprensa na Cisjordânia. "Somos parceiros dos israelenses. Eles não têm o direito de escolher seus parceiros, mas, se procuram um parceiro palestino, ele existe", acrescentou.

O governo de Israel não comentou oficialmente o resultado das eleições.

Com agências internacionais

\section{Leia mais}

Eleições parlamentares palestinas terminam em Gaza e Cisjordânia Partido governista Fatah reconhece derrota em eleições palestinas

\section{Especial}

Leia cobertura completa sobre as eleições palestinas

Leia o que já foi publicado sobre as eleições palestinas 


\section{Wahlergebnis im Irak}

\section{Schiiten verfehlen einfache Mehrheit}

20. Januar 2006 Bei der irakischen Parlamentswahl haben die Schiiten nach dem offiziellen Endergebnis ihre dominante Rolle behauptet, eine einfache Mehrheit jedoch knapp verfehlt. Mit 128 Sitzen fehlen der regierenden Vereinigten Irakischen Allianz demnach im neuen Parlament zehn Sitze, um wie bisher mehr als die Hälfte der 275 Abgeordneten zu stellen.

Ihr bisheriger Koalitionspartner, der Kurdische Block, kam auf 53 Sitze. Das Resultat legte die Wahlkommission am Freitag in Bagdad vor. Drittstärkste Kraft wurde demnach das größte Bündnis sunnitischer Gruppierungen, die erstmals nach dem Sturz von Saddam Hussein bei einer Wahl antraten. Die Irakische Eintracht eroberte 44 Sitze. Elf Sitze gingen an ein weiteres sunnitisches Bündnis, die Front des Nationalen Dialogs.

Das säkular ausgerichtete Bündnis des ehemaligen Ministerpräsidenten Ijad Allawi erreichte 25 Sitze und blieb damit deutlich hinter seinem bisherigen Anteil zurück. Das Ergebnis entsprach den Erwartungen und brachte kaum Veränderungen gegenüber den bislang vorläufig bekannt gewordenen Sitzverteilungen. Das Parlament ist das erste seit dem IrakKrieg, das für eine volle Legislaturperiode gewählt ist.

Vor allem Sunniten hatten allerdings gegen Wahlfälschungen protestiert. Eine internationale Prüferkommission war in einem am Donnerstag vorgelegten Bericht zu dem Schluß gekommen, daß es Manipulationen gegeben habe, diese aber nicht das Gesamtergebnis in Frage stellten.

Zum Thema:

\section{FAZ.NET-Spezial: Wahl im Irak}




\section{Bush diz que há "obrigação" de impedir que Irã tenha armas nucleares da Folha Online}

O presidente americano, George W. Bush, afirmou nesta sexta-feira durante coletiva de imprensa em Washington que existe uma "obrigação" de impedir que o Irã possua armas nucleares em seu poder.

"O Irã com uma arma nuclear representaria uma grave ameaça à segurança do mundo todo. Países como os nossos têm a obrigação de trabalhar juntos e enviar uma mensagem comum ao governo iraniano", disse Bush durante uma coletiva de imprensa ao lado da chanceler alemã Angela Merkel, em Washington.

"É lógico que um país que rejeitou a diplomacia e os tratados seja enviado ao Conselho de Segurança (CS) da ONU", acrescentou.

Questionado a respeito de eventuais sanções ao Irã, Bush disse que evitaria tentar "prever" a decisão do CS e ressaltou seu desejo de resolver a questão de "maneira diplomática".

O Irã removeu os lacres no centro de pesquisas nucleares para o enriquecimento de urânio nesta terça-feira, anunciando que retomaria a "pesquisa e desenvolvimento" nucleares com urânio, causando imediata reação dos Estados Unidos, da União Européia (UE) e da Rússia.

\section{"Linha dura"}

Merkel, por sua vez, afirmou que o Irã não intimida a comunidade internacional. "Não seremos intimidados pelo Irã", disse a chanceler.

A líder alemã disse estar "muito satisfeita" com o diálogo com Bush e afirmou que seu país adotará uma "linha dura" com o Irã.

"Para nós, alemães, é totalmente inaceitável o que o Irã disse recentemente, por exemplo, ao questionar o direito de existência de Israel, ou as declarações que foram feitas a respeito do Holocausto", acrescentou.

O Irã ameaçou nesta sexta-feira suspender as inspeções relâmpago da ONU (Organização das Nações Unidas) em suas instalações nucleares, se o reinício das pesquisas nucleares no país for levado ao Conselho de Segurança do órgão.

A ameaça foi feita depois que Reino Unido, França e Alemanha desistiram dos esforços conjuntos para uma solução negociada.

Os três países--que tentaram, em vão, obter do Irã garantias a respeito do abandono de seu programa nuclear militar-- devem se reunir em Londres com diplomatas da China, da Rússia e dos Estados Unidos na próxima segunda-feira (16), para discutir a questão iraniana.

\section{Leia mais}

$\underline{\text { Irã levaria anos para ter a bomba, dizem especialistas }}$

\section{Especial}

Leia o que já foi publicado sobre o programa nuclear iraniano 


\section{Kanzlerin im Weißen Haus Bush mit Zeit und Lob für Merkel}

13. Januar 2006 In Washington war man gespannt auf „die Neue” aus Deutschland. Präsident George W. Bush hatte sich am Freitag viel Zeit für Bundeskanzlerin Angela Merkel (CDU) genommen. Rund drei Stunden verbrachten ,the Cowboy and the Angel”, wie die „Washington Times” beide im Vorfeld titulierte, miteinander in Gesprächen - auch bei einer gemeinsamen Pressekonferenz und beim anschließenden Mittagessen.

Auch das sollte signalisieren, daß die frostigen Zeiten im deutsch-amerikanischen Verhältnis endgültig vorüber sind. Dabei fiel die Begrüßung Merkels im Oval Office nicht ganz so überschwenglich aus, wie manch einer erwartet hatte. Doch große Gesten der Herzlichkeit sind ohnehin nicht Merkels Stil. Nach ihrem Frühstück mit Kongreßmitgliedern war Merkel die rund hundert Meter vom Nordosteingang des Parks am Weißen Haus zum Westflügel des Gebäudes zu Fuß gegangen und hatte die kalte, dunstige Morgenluft genossen.

„The Cowboy and the Angel”

Merkels außenpolitischer Berater Christoph Heusgen und ihr Sprecher Ulrich Wilhelm gaben ihr während des Gangs letzte Instruktionen mit auf den Weg. Derweil wartete der Präsident in seinem Amtszimmer, wo er sie an der Tür mit einem Händedruck begrüßte. Danach schlossen sich die Türen zum Vier-Augen-Gespräch für 45 Minuten. Auf der Pressekonferenz später war die Stimmung zwischen Merkel und Bush gelöster. Merkel, so lobte Bush, sei „hochintelligent”. Vor allem glaubt er in der Kanzlerin eine Vertraute im Geiste gefunden zu haben: „Sie hat einen gewissen Geist, der mir sehr zusagt. Sie liebt die Freiheit”, hob der Präsident hervor. Beide vereine zudem, daß sie nicht durch erdrutschartige Wahlsiege ins Amt gekommen seien.

Als die Rede auf Merkels Vorgänger Gerhard Schröder (SPD) kam, ist Bush das Heikle der Frage im Gesicht abzulesen. Doch der Präsident bleibt diplomatisch. Er grüße Schröder und hoffe, daß es ihm gut gehe, sagte Bush. Merkel will mit den Amerikanern nun ein „neues Kapitel" in den bilateralen Beziehungen aufschlagen, und das Treffen mit Bush sei ein ,guter Anfang" gewesen. Es geht Merkel um ein Verhältnis, in dem man auch offene und ehrliche Worte finden kann, ohne daß sie gleich die Beziehungen belasten. Unter diesem Gesichtspunkt sind auch Merkels Bedenken gegen das Gefangenenlager Guantanamo auf Kuba zu werten, die sie im Weißen Haus vortrug - und die Bush zurückwies.

\section{„Guter Anfang”}

Auch in anderen Fragen sind die Vereinigten Staaten und Deutschland nicht immer einer Meinung, beispielsweise bei der Rolle der Uno oder in der Klimapolitik. Und in der TürkeiFrage setzt Washington im Gegensatz zu Merkels CDU auf eine Vollmitgliedschaft in der EU. In den Mittelpunkt der künftigen Beziehungen will Merkel aber „Gemeinsames, und nicht Trennendes stellen”. In der Einschätzung der Gefährlichkeit des Terrorismus sei man sich „völlig einig”, auch setzen Deutschland und die Vereinigten Staaten auf eine diplomatische Lösung der Krise um die atomaren Ambitionen des Iran. Merkel will zudem den wirtschaftlichen Austausch und die Forschungskooperationen vorantreiben. Kurzum: es geht der Kanzlerin um eine Intensivierung der Kontakte. Sie glaube, daß ein Teil der Mißverständnisse der Vergangenheit zwischen den Regierungen auch auf zu wenige Kontakte zurückzuführen sei, sagte sie überzeugt. Bereits im Mai wird sie wieder nach Übersee reisen. Anlaß ist das 100jährige Bestehen des American Jewish Committee. 
Abseits der großen Weltthemen war der Besuch für Merkel zum Kennenlernen der amerikanischen Administration wichtig. Vor ihrer Antrittsreise in die Vereinigten Staaten hatte sie Bush nur einmal getroffen, nämlich vor einem Jahr für knapp 15 Minuten. Zwar war Merkel schon einmal im Februar 2003 im Weißen Haus - damals traf sie aber nur Vizepräsident Dick Cheney. Das Vergnügen, daß plötzlich Bush dazu stößt, wie es Hessens Ministerpräsident Roland Koch (CDU) und der frühere Innenminister Otto Schily (SPD) bei ihren Besuchen erfahren durften, war Merkel damals nicht vergönnt.

\section{Mit Deutschland rechnen}

Für gute Beziehungen müsse man sich auch Zeit nehmen, machte Merkel bei ihrer Visite in Washington nun deutlich. Dazu reichten zwei oder drei Stunden im Jahr nicht aus. Eine ,neue Romanze" wird aus dem Verhältnis Bush-Merkel wohl kaum, wie die „Washington Times” im Vorfeld mutmaßte. Wohl ist aber mit einem engeren Verhältnis zu rechnen, das sich auf Verläßlichkeit und Sachlichkeit gründet.

Schon beim Abendessen nach ihrer Ankunft am Donnerstag abend in der Residenz des deutschen Botschafters Wolfgang Ischinger wurde die neue Lockerheit in den Beziehungen offensichtlich. Merkel scherzte mit dem ehemaligen amerikanischen Außenminister Colin Powell, plauderte mit der früheren Außenministerin Madeleine Albright und dem scheidenden Notenbankchef Alan Greenspan. Ihm erzählte Merkel, daß der erste Computer von dem Deutschen Konrad Zuse gebaut wurde - und daß Deutschland an solche Leistungen wieder anknüpfen will. Will heißen: Die Vereinigten Staaten können auf die Deutschen zählen und sollen auch mit ihnen rechnen.

\section{Zum Thema:}

Bush und Merkel wollen Iran-Konflikt diplomatisch lösen

Merkels Reise nach Washington: „Zu Gast bei Freunden”

Merkel soll Bush überzeugen, Guantánamo zu schließen 